\title{
MOLECULAR INSIGHTS INTO THE NICHE OF HARMFUL BROWN TIDES
}

By

\author{
Louie L. Wurch \\ B.S., Humboldt State University, 2005
}

Submitted in partial fulfillment of the requirements for the degree of

Doctor of Philosophy

at the

MASSACHUSETTS INSTITUTE OF TEC.HNOLOGY

and the

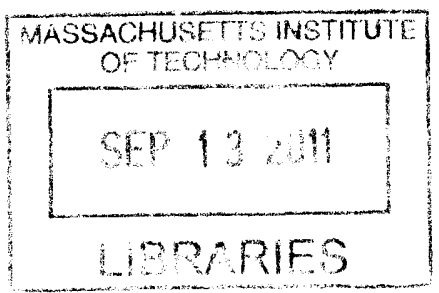

WOODS HOLE OCEANOGRAPHIC INSTITUTION

ARCHIVES

September 2011

(C) 2011 Louie L. Wurch

All rights reserved.

The author hereby grants to MIT and WHOI permission to reproduce and to distribute publicly paper and electronic copies of this thesis document in whole or in part in any medium now known or hereafter created.

Signature of Author

$$
\begin{array}{r}
\text { Joint Program in Oceanography/Applied Ocean Science and Engineering } \\
\text { Massachusetts Institute of Technology } \\
\text { and Woods Hole Oceanographic Institution }
\end{array}
$$

Certified by

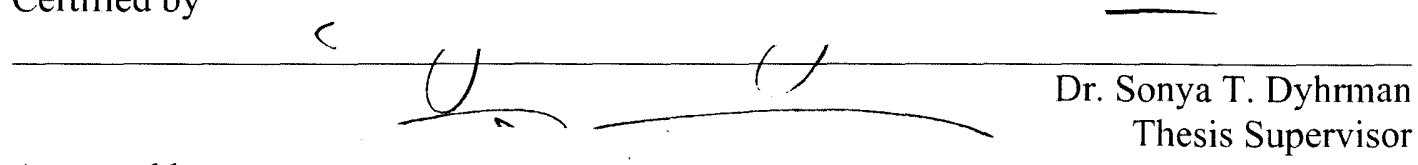

Accepted by

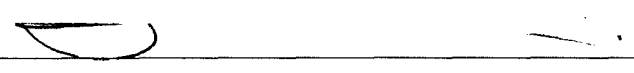

Dr. Simon Thorrold

Chair, Joint Committee for Biological Oceanography

Woods Hole Oceanographic Institution 


\title{
Molecular Insights into the Niche of Harmful Brown Tides
}

\author{
By Louie Wurch \\ Submitted in partial fulfillment of the requirement \\ for the degree of Doctor of Philosophy in \\ Biological Oceanography
}

Recurrent brown tide blooms caused by the harmful alga Aureococcus anophagefferens have decimated coastal ecosystems and shellfisheries along the Eastern U.S and South Africa. The exact mechanisms controlling bloom formation, sustenance, and decline are unclear, however bottom-up factors such as nutrient type and supply are thought to be critical. Traditional assays for studying algal nutrient physiology require bulk community measurements or in situ nutrient perturbations. Although useful, these techniques lack the ability to target individual species in complex, mixed microbial assemblages. The motivation for this thesis is to examine the metabolic strategies utilized by $A$. anophagefferens for meeting its nitrogen $(\mathrm{N})$ and phosphorus $(\mathrm{P})$ demand at the cellular level using molecular tools that, even in the presence of complex microbial assemblages, can be used to track how nutrients influence the bloom dynamics of $A$. anophagefferens in the environment. Chapter two examines the global transcriptional responses of $A$. anophagefferens to $\mathrm{N}$ and $\mathrm{P}$ deficiency. Results demonstrate that $A$. anophagefferens has the capacity to utilize multiple forms of organic $\mathrm{N}$ and $\mathrm{P}$ when inorganic forms become unavailable. Chapter three analyzed the global protein changes in response to $\mathrm{P}$ deficiency and $\mathrm{P}$ re-supply. Consistent with transcript patterns, $A$. anophagefferens increases protein abundance for a number of genes involved in inorganic and organic $\mathrm{P}$ metabolism when inorganic $\mathrm{P}$ is deficient. Furthermore, increases in a sulfolipid biosynthesis protein combined with lipid data suggest $A$. anophagefferens can adjust its $\mathrm{P}$ requirement by switching from phospholipids to sulfolipids when inorganic $P$ is unavailable. Analysis of protein abundances from Pdeficient cells that were re-fed inorganic $P$ demonstrates variations in the timing of turnover among various proteins upon release from phosphate deficiency. Chapter four tests the expression patterns of candidate gene markers of nutrient physiology under controlled culture experiments. Results show that expression patterns of a phosphate transporter and xanthine/uracil/vitamin $\mathrm{C}$ permease are indicators of $\mathrm{P}$ and $\mathrm{N}$ deficiency, respectively. Taken together, these findings provide insight into the fundamental and ecological niche space of this harmful algal species with respect to $\mathrm{N}$ and $\mathrm{P}$ and provide $\mathrm{a}$ platform for assaying nutrient controls on natural brown tide blooms.

Thesis Supervisor:

Dr. Sonya T. Dyhrman

Title: Associate Scientist, Biology Department, Woods Hole Oceanographic Institution 


\section{Acknowledgments}

Throughout my career as a graduate student I have was supported by the Woods Hole Oceanographic Institution Academic Programs Office, an EPA STAR graduate fellowship (\#FP916901). I also utilized funds from a student research grant from the Woods Hole Coastal Ocean Institute, a National Oceanic and Atmospheric Administration ECOHAB grant (\#NA09NOS4780206), and National Science Foundation grant (\#OCE-0723667)

A Ph.D. thesis represents an incredible amount of work over a long period of time. There were countless people that have contributed either directly to my thesis by assisting me in research, discussions, etc., or indirectly by providing support and much needed distractions. First and foremost, I have to thank my advisor and mentor Sonya Dyhrman. She has put a tremendous amount of effort into training me to be a scientist and a colleague and has provided invaluable feedback and guidance in my thesis research. I would also like to thank my thesis committee: Prof. Christopher Gobler, Dr. Donald Anderson, Dr. Scott Doney, and Prof. Edward DeLong. It is a substantial amount of work to serve on a thesis committee and requires a great deal of time. I am very thankful for all of your guidance through this process. It is an amazing experience to have such successful scientists guide me and help me critically think about my research. Finally, I would like to thank my family and friends for your support. I could not hope to possibly name and thank everyone properly, but please know I appreciate all of you and your support. 


\section{Table of Contents}

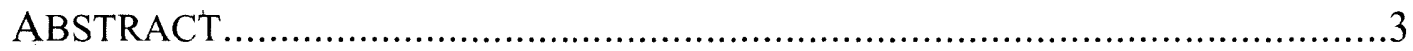

ACKNOWLEDGMENTS.................................................................. 5

TABLE OF CONTENTS.................................................................... 7

CHAPTER ONE: Introduction...........................................................

CHAPTER TWO: Nutrient-regulated transcriptional responses in the brown tide-forming alga Aureococcus anophagefferens..................................2 1

CHAPTER THREE: Proteome changes driven by phosphorus deficiency and recovery in the brown tide-forming alga, Aureococcus anophagefferens.....37

CHAPTER FOUR: Targeted gene expression in cultures and field populations of Aureococcus anophagefferens: Patterns in nitrogen and phosphorus

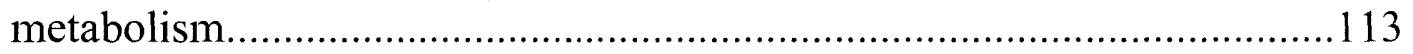

CHAPTER FIVE: Summary and future directions....................................163 


\section{CHAPTER ONE}

\section{Introduction}

Phytoplankton in the world's oceans account for roughly half of all primary production on Earth (Field et al 1998). Through the uptake and fixation of $\mathrm{CO}_{2}$ into organic carbon, phytoplankton form the base of the marine food web, are essential in exporting $\mathrm{CO}_{2}$ from the atmosphere to the deep ocean (thus critical in regulating climate), and drive the biogeochemical cycling of nitrogen $(\mathrm{N})$, phosphorus $(\mathrm{P})$, and other important nutrients. Therefore understanding the controls on phytoplankton growth remains a key area of oceanographic research.

Nutrient availability is a principal factor governing phytoplankton growth in the ocean and different phytoplankton species all require the same basic nutrients to grow (e.g. N, P, iron, etc.). G.E. Hutchinson initially proposed a paradox in 1961 termed the "paradox of the plankton". According to the law of competitive exclusion, if multiple species compete for the same resource, eventually one species alone should outcompete all the others so that in a final state of equilibrium, only one species would exist (Gause 1932). There are many species of phytoplankton present in the ocean, and understanding how individual species partition themselves into the distinct niches that must allow them to co-occur in the ocean remains a fundamental challenge. Conversely, occasionally a given set of environmental variables will lead to temporary competitive exclusion, whereby one phytoplankton species will dominate the system leading to monospecific algal blooms (e.g. brown tide blooms, Gobler et al. 2005, Sunda et al. 2006). If the build- 
up of biomass from one phytoplankton species has negative consequences to the ecosystem it is referred to a harmful algal bloom (HAB). Note, however, that not all HABs are the result of one species dominating the system. For example, some phytoplankton produce toxins that can be harmful even at very low cell concentrations (Burkholder and Glasgow 1997, Smayda 1997). Nonetheless, numerous HABs form due to the ability of certain phytoplankton species to outcompete other phytoplankton species under certain conditions, leading to monospecific, or nearly monospecific, blooms.

Due to the impacts of HABs on the environment, fisheries, and human health, a substantial amount of effort has been poured into the mechanisms by which HABforming species can exploit a given geochemical environment (e.g. see reviews by Smayda et al. 2006 and Anderson et al. 2008). Traditional methods for studying how HAB species interact and compete with co-ocurring species under variable geochemical conditions rely on cultured isolates or community level assays for determining factors such as nutrient preference, uptake rates, and elemental composition (Dyhrman 2008). Molecular methods offer a means in which the nutrition of individual species living in complex mixed assemblages can be examined at the cellular level. This, in turn, allows a way by which the realized niche space of an individual speices can be resolved.

The entire physiological potential of an organism is encoded in its genome. For instance, the genome sequencing of the diatom Thalassiosira pseudonana identified novel genes for silica transport, a complete urea cycle, and a variety of genes for utilizing exogenous nutrient compounds (Armbrust et al. 2004). A genomic comparison between two species of the picoeukaryote Ostreococcus provided insight into how these two 
organisms diverged and adapted to unique ecological niches (Palenik et al. 2007). The reader is also directed to Scanlan et al. 2009 for a review on how niche adaptation and ecological success are reflected in the genomes of two genera of cyanobacteria. The recent genome sequencing of the $\mathrm{HAB}$ species Aureococcus anophagefferens has demonstrated that this species is well adapted to anthropogenically-influenced estuaries (Gobler et al. 2011).

The genome of an organism reveals the physiological capacity of that organism, but it is the ordered expression of that genome that ultimately dictates how an organism is adjusting to its current environment. For example, under $\mathrm{N}$ and $\mathrm{P}$ deficiency, some phytoplankton will induce genes for efficiently scavenging nutrients from a variety of sources and this induction can be seen at the transcriptional level (Grossman 2000, Dyhrman 2008). Global transcriptome profiling studies have also examined nutrient deficiency responses in coccolithophores, dinoflagellates, diatoms, and the pelagophyte A. anophagefferens (Dyhrman et al. 2006, Erdner and Anderson 2006, Mock et al. 2008, Wurch et al. 2011). A targeted study of $\mathrm{N}$ metabolism genes in A. anophagefferens demonstrated the up-regulation of transporters for nitrate, formate/nitrite, urea, ammonium, and amino acids among others during general $\mathrm{N}$ deficiency (Berg et al. 2008). Proteomic studies are complementary to genomic and transcriptomic studies because protein represents the end product of gene expression. Recently, mass spectrometry-based proteomic approaches have been used to analyze biosynthetic and metabolic pathways in the diatom T. pseudonana, the picoeukaryote Ostreococcus tauri, and the cyanobacterium Crocosphaera watsonii (Nunn et al. 2009, Saito et al. 2011, Le 
Bihan et al. 2011). Transcriptome and proteome studies reveal how phytoplankton can tailor the expression of their genomes to adjust to variations in their geochemical environment, providing key insight into competition, nutrient scavenging/metabolism, and nutrient conservation strategies. These parameters can be used to outline the realized niche space for individual phytoplankton species.

\section{A. anophagefferens as a model species}

As mentioned above, it is particularly critical to understand the strategies and niche space of those species that cause negative consequences to the ecosystem, as is the case for HABs. Occasionally, one phytoplankton species can exploit a given environment to the complete exclusion of all other competitors. An example of this is the brown tide events that have caused extensive damage to coastal ecosystems in the eastern United States and South Africa (Gobler et al. 2005). Brown tides are caused by $A$. anophagefferens, a relatively small $(\sim 2 \mu \mathrm{m}$ diameter $)$ eukaryotic phytoplankton species within the algal class Pelagophyceae (DeYoe et al. 1997). A related alga, Aureoumbra lagunensis, is responsible for brown tides in Texas (DeYoe et al. 1995, 1997). Brown tide events caused by $A$. anophagefferens occur almost annually in waters around Long Island (Gobler et al. 2005).

A. anophagefferens has emerged as a model phytoplankton species for studying high biomass $\mathrm{HABs}$ due to its severe impact upon the coastal ecosystem and much attention has been paid to understanding what causes brown tides to form (Gobler et al. 2005, Sunda et al. 2006). Culture work has demonstrated that A. anophagefferens can 
access $\mathrm{N}$ from a variety of sources. This includes dissolved inorganic $\mathrm{N}$ (DIN) compounds such as nitrate and ammonium, and dissolved organic N (DON) compounds such as urea, formamide, amino acids, chitobiose, and acetamide (Berg et al. 2002, Mulholland et al. 2002, MacIntyre et al. 2004, Pustizzi et al. 2004, Berg et al. 2008). In field studies, natural assemblages of phytoplankton during brown tide events can utilize DON compounds (e.g. urea and amino acids) and A. anophagefferens has a relatively higher affinity for reduced $\mathrm{N}$ (e.g. ammonia) and DON relative to nitrate (Lomas et al. 1996, Berg et al. 1997; 2003, Mulholland et al. 2002; 2004). Low nitrate inputs resulting from variability in groundwater flow have been positively correlated to brown tides around Long Island (LaRoche et al. 1997). Mesocosm experiments during a natural bloom pointed to an inverse correlation between DIN enrichment and $A$. anophagefferens cell densities (Keller and Rice, 1989). Further evidence showed that DIN enrichment led to a decrease in the relative abundance of $A$. anophagefferens within the phytoplankton community (Gobler and Sañudo-Wilhelmy 2001 b, Gobler et al. 2002; 2004, Kana et al. 2004).

The data from these studies suggest that $A$. anophagefferens prefers reduced and organic forms of $\mathrm{N}$ to nitrate. However, in culture, A. anophagefferens has similar growth rates whether the sole $\mathrm{N}$ source is nitrate or urea (MacIntyre et al. 2004, Pustizzil et al. 2004). Using growth rates in cultures of competing phytoplankton species grown on various $\mathrm{N}$ sources, model simulations predicted that of the species tested, diatoms and cyanobacteria would dominate phytoplankton communities supplied primarily with nitrate, while $A$. anophagefferens will dominate phytoplankton communities primarily 
supplied with ammonia and DON (Taylor et al. 2006). These model simulations are consistent with field observations showing significant reductions in DON as $A$. anophagefferens cell densities increase (Gobler et al. 2004).

Far less is known about the role of $\mathrm{P}$ in brown tide events. As with DIN, brown tides tend to correlate with relatively low DIP concentrations (Gobler et al. 2005) and there is a significant drawdown of DOP during peak $A$. anophagefferens cell densities (Gobler et al. 2004). Culture work demonstrated that both non-axenic and axenic strains of A. anophagefferens could utilize DOP (e.g. glycerol-phosphate, adenosine monophosphate) as a sole P source (Dzurica et al. 1989, Wurch et al. 2011). Therefore, DOP may be important in fueling blooms when DIP is unavailable.

Taken together, these past studies have demonstrated that (1) A. anophagefferens can utilize DON and DOP in culture; (2) brown tides generally correlate with low levels of DIN and DIP; and (3) there is a reduction in DON and DOP during peak bloom periods. This suggests that $A$. anophagefferens gains competitive advantages when inorganic nutrients become depleted while organic nutrients are still available. The goal of this thesis is to determine the molecular mechanisms by which A. anophagefferens takes advantage of this scenario allowing it to outcompete co-occurring phytoplankton species and to use these data to confirm additional details of the realized niche space that would not be possible with community level assays. The specific data chapters are outlined below: 
Chapter 2: Nutrient-regulated transcriptional responses in the brown tide-forming alga Aureococcus anophagefferens.

Global transcriptional responses were analyzed under N- and P-deficient conditions to identify the metabolic strategies employed by $A$. anophagefferens to cope with $\mathrm{N}$ and $\mathrm{P}$ deficiency (Wurch et al. 2011).

Chapter 3: Proteome changes driven by phosphorus deficiency and recovery in the brown tide-forming alga, Aureococcus anophagefferens.

The global protein abundances of $A$. anophagefferens were profiled to determine which proteins were differentially abundant under P-deficient conditions and whether changes in the P-deficient transcriptome were manifested at the protein level. Global protein abundances were also assayed for P-deficient cells that had been re-fed phosphate and allowed 24 hours to respond, providing insight into the timing of protein turnover.

Chapter 4: Targeted gene expression in culture and field populations of Aureococcus anophagefferens: Patterns in nitrogen and phosphorus metabolism.

Expression patterns of target genes involved in $\mathrm{N}$ and $\mathrm{P}$ metabolism were analyzed under a variety of culture conditions. Those genes whose expression patterns are indicative of $\mathrm{N}$ or $\mathrm{P}$ deficiency were examined in natural field samples of $A$. anophagefferens during a bloom in Quantuck Bay, 2007. 


\section{References:}

Anderson, D.M., Burkholder, J.M., Cochlan, W.P., Glibert, P.M., Gobler, C.J., Heil, C.A., et al. (2008) Harmful algal blooms and eutrophication: Examining linkages from selected coastal regions of the United States. Harmful Algae 8: 39-53.

Armbrust, E.V., Berges, J.A., Bowler, C., Green, B.R., Martinez D., et al. (2004) The genome of the diatom Thalassiosira pseudonana: Ecology, evolution, and metabolism. Science 306: 79-86.

Berg, G. M., Glibert, P.M., Lomas, M.W., and Burford, M.A. (1997) Organic nitrogen uptake and growth by the chrysophyte Aureococcus anophagefferens during a brown tide event. Mar. Biol. 129: 377-387.

Berg, G.M., Repeta, D.J., and LaRoche, J. (2002) Dissolved organic nitrogen hydrolysis rates in axenic cultures of Aureococcus anophagefferens (Pelagophyceae): comparison with heterotrophic bacteria. Appl. Environ. Microbiol. 68: 401-404.

Berg, G.M., Repeta, D.J., and LaRoche, J. (2003) The role of the picoeukaryote Aureococcus anophagefferens in cycling of marine high-molecular weight dissolved organic nitrogen. Limnol. Oceanogr. 48: 1825-1830.

Berg, G.M., Shrager, J., Glockner, G., Arrigo, K.R., and Grossman, A.R. (2008) Understanding nitrogen limitation in Aureococcus anophagefferens (Pelagophyceae) through cDNA and qRT-PCR analysis. J. Phycol. 44: 1235-1249.

Burkholder, J.M., and Glasgow, H.B. (1997) Pfiesteria piscicida and other Pfiesteria-like dinoflagellates: Behavior, impacts, and environmental controls. Limnol. Oceanogr. 42: 1052-1075.

DeYoe, H.R., Chan, A.M., and Suttle C.A. (1995) Phylogeny of Aureococcus anophagefferens and a morphologically similar bloom-forming alga from Texas as determined by $18 \mathrm{~S}$ ribosomal RNA sequence analysis. J. Phycol. 31: 413-418.

DeYoe, H.R., Stockwell, D., Bidigare, R., Latasa, M., Johnson, P., Hargraves, P., and Suttle, C. (1997) Description and characterization of the algal species Aureoumbra lagunensis gen. et sp. Nov. and referral of Aureoumbra and Aureococcus to the Pelagophyceae. J. Phycol. 33: 1042-1048.

Dyhrman, S.T., Haley, S.T., Birkeland, S.R., Wurch, L.L., Cipriano, M.J., and McArthur, A.G. (2006) Long Serial Analysis of Gene Expression for gene discovery and transcriptome profiling in the widespread marine coccolithophore Emiliania huxleyi. Appl. Environ. Microbiol.72: 252-260. 
Dyhrman, S.T. (2008) Molecular approaches to diagnosing nutritional physiology in harmful algae: Implications for studying the effects of eutrophication. Harmful Algae 8: 167-174.

Dzurica, S., Lee, C., Cosper, E.M., and Carpenter, E.J. (1989) Role of environmental variables, specifically organic compounds and nutrients, in the growth of the chrysophyte Aureococcus anophagefferens. p. 229-252. In E.M. Cosper, V.M. Bricelj, and E.J. Carpenter (eds.), Novel Phytoplankton Blooms: Causes and Impacts of Recurrent Brown Tides and Other Unusual Blooms, Volume 35. Springer, New York.

Erdner, D.L., and Anderson, D.M. (2006) Global transcriptional profiling in the toxic dinoflagellate Alexandrium fundyense using massively parallel signature sequencing. BMC Genomics 7: 88.

Field, C.B., Behrenfeld, M.J., Randerson J.T., and Falkowski, P. (1998) Primary production of the biosphere: Integrating terrestrial and oceanic components. Science 281: 237-240.

Gause, G.F. (1932) Experimental studies on the struggle for existence: 1. Mixed population of two species of yeast. J. Exp. Biol. 9: 389-402.

Gobler, C.J., and Sañudo-Wilhelmy, S.A. (2001a) Temporal variablility of groundwater seepage and brown tide blooms in a Long island embayment. Mar. Ecol. Prog. Ser. 217: 299-309.

Gobler, C.J., and Sañudo-Wilhelmy, S.A. (2001b) Effects of organic carbon, organic nitrogen, inorganic nutrients, and iron additions on the growth of phytoplankton and bacteria during a brown tide bloom. Mar. Ecol. Prog. Ser. 209: 19-34.

Gobler, C.J., Renaghan, M.J., and Buck, N.J. (2002) Impacts of nutrients and grazing mortality on the abundance of Aureococcus anophagefferens during a New York brown tide bloom. Limnol. Oceanogr. 47: 129-141.

Gobler, C.J., Boneillo, G.E., Debenham, C., and Caron, D.A. (2004) Nutrient limitation, organic matter cycling, and plankton dynamics during an Aureococcus anophagefferens bloom in Great South Bay, N.Y. Aquat. Microb. Ecol. 35: $31-43$.

Gobler, C.J., Lonsdale, D.J., and Boyer, G.L. (2005) A review of the causes, effects, and potential management of harmful brown tide blooms caused by Aureococcus anophagefferens (Hargraves et Sieburth). Estuaries 28: 726-749.

Gobler, C.J., Berry, D.L., Dyhrman, S.T., Wilhelm, S.W., Salamov, A. et al. (2011) Niche of harmful algal Aureococcus anophagefferens revealed through ecogenomics. 108: $4352-4357$. 
Grossman, A. (2000) Acclimation of Chlamydomonas reinhardtii to its nutrient environment. Protist 151: 201-224.

Hutchinson, G. E. (1961) The paradox of the plankton. American Naturalist 95: 137-145.

Kana, T.M., Lomas, M.W., MacIntyre H.L., Cornwell, J.C., and Gobler, C.J. (2004) Stimulation of the brwon tide organism, Aureococcus anophagefferens, by selective nutrient additions to in situ mesocosms. Harmfil Algae 3: 377-388.

Keller, A.A., and Rice, R.L. (1989) Effects of nutrient enrichment on natural populations of the brown tide phytoplankton Aureococcus anophagefferens (Chrysophyceae). $J$. Phycol. 25: 636-646.

LaRoche, J., Nuzzi, R., Waters, R., Wyman, K., Falkowski, P.G., and Wallace, D.W.R. (1997) Brown tide blooms in Long Island's coastal waters linked to variability in groundwater flow. Glob. Change Biol. 3: 397-410.

Le Bihan, T., Martin, S.F., Chirnside, E.S., van Ooijen, G, Barrios-LLenera, M.E., et al. (2011) Shotgun proteomic analysis of the unicellular alga Ostreococcus tauri, J. Prot.

doi:10.1016/j.jprot.2011.05.028

Lomas, M. W., Glibert, P.M., and Berg, G.M. (1996) Characterization of nitrogen uptake by natural populations of Aureococcus anophagefferens (Chrysophyceae) as a function of incubation duration, substrate concentration, light, and temperature. J. Phycol. 32: 907916.

Mock T., Samanta M.P., Iverson V., Berthiaume C., Robison M., Holtermann K., et al. (2008) Whole genome expression profiling of the marine diatom Thalassiosira pseudonana identifies genes involved in silicon bioprocesses. Proc. Nat. Acad. Sci. U.S.A. 105:1579-1584.

Mulholland, M.R., Gobler, C.J., and Lee, C. (2002) Peptide hydrolysis, amino acid oxidation and $\mathrm{N}$ uptake in communities seasonally dominated by Aureococcus anophagefferens. Limnol. Oceanogr. 47: 1094-1108.

Mulholland, M.R., Boneillo, G., and Minor E.C. (2004) A comparison of N and C uptake during brown tide (Aureococcus anophagefferens) blooms from two coastal bays on the east coast of the USA. Harmful Algae. 3: 361-376.

Nunn, B.L., Aker, J.R., Shaffer, S.A., Tsai, Y., Strzepek R.F., et al. (2009) Deciphering diatom biochemical pathways via whole-cell proteomics. Aquat. Microb. Ecol. 55: 241253. 
Palenik, B., Grimwood, J., Aerts, A., Rouze, P., Salamov, A, et al. (2007) The tiny eukaryote Ostreococcus provides genomic insights into the paradox of plankton speciation. PNAS 104: 7705-7710.

Pustizzi, F., MacIntyre, H.L., Warner, M.E., and Hutchins, D.A. (2004) Interaction of nitrogen source and light intensity on the growth and photosynthesis of the brown tide alga Aureococcus anophagefferens. Harmful Algae 3: 343-360.

Saito, M.A., Bertrand, E.M., Dutkiewicz, S., Bulygin, V.V., Moran, D.M. et al. (2011) Iron conservation by reduction of metalloenzyme inventories in the marine diazotroph Crocosphaera watsonii. PNAS 108: 2184-2189.

Scanlan, D.J., Ostrowski, M., Mazard, S., Dufresne, A., Garczarek, L. et al. (2009) Ecological Genomics of Marine Picocyanobacteria. Microbiol. Mol. Biol. R. 73: 249-299.

Smayda, T.J. (1997) Harmful algal blooms: Their ecophysiology and general relevance to phytoplankton blooms in the sea. Limnol. Oceanogr. 42: 1137-1153.

Sunda, W.G., Graneli, E., and Gobler, C.J. (2006) Positive feedback and the development and persistence of ecosystem disruptive algal blooms. J. Phycol. 42: 963-974.

Taylor, G.T., Gober, C.J., and Sañudo-Wilhelmy, S.J. (2006) Speciation and concentrations of dissolved nitrogen as determinants of brown tide Aureococcus anophagefferens bloom initiation. Mar. Ecol. Prog. Ser. 312: 67-83.

Wurch L.L., Haley S.T., Orchard E.D., Gobler C.J., and Dyhrman S.T. (2011) Nutrientregulated transcriptional responses in the brown tide forming algal Aureococcus anophagefferens. Environ. Microbiol. 13: 468-481. 
CHAPTER TWO

Nutrient-regulated transcriptional responses in the brown tide-forming alga

Aureococcus anophagefferens

\author{
Louie L. Wurch ${ }^{\mathrm{a}}$ \\ Sheean T. Haley ${ }^{b}$ \\ Elizabeth D. Orchard ${ }^{\mathrm{a}}$ \\ Christopher J. Gobler ${ }^{\mathrm{c}}$ \\ Sonya T. Dyhrman ${ }^{\text {b.d }}$
}

aMIT-WHOI Joint Program in Oceanography/Applied Ocean Science and Engineering, Cambridge, MA 02139

${ }^{b}$ Woods Hole Oceanographic Institution Biology Department

Woods Hole, MA 02543

${ }^{\mathrm{c}}$ Stony Brook University, School of Marine and Atmospheric Sciences

Stony Brook, NY 11794

${ }^{d}$ Corresponding author: sdyhrman@whoi.edu Fax: (508) 457-2134

Reprinted with permission from Environmental Microbiology

(C) 2011 Society for Applied Microbiology and Blackwell Publishing Ltd

Wurch, L.L., Haley, S.T., Orchard, E.D., Gobler, C.J., and Dyhrman S.T. (2011) Nutrient-regulated transcriptional responses in the brown tide-forming alga Aureococcus anophagefferens. Environ. Micobiol. 13: 468-481. 


\section{Nutrient-regulated transcriptional responses in the brown tide-forming alga Aureococcus anophagefferens}

Louie L. Wurch, ${ }^{1}$ Sheean T. Haley, ${ }^{2}$

Elizabeth D. Orchard, ${ }^{1}$ Christopher J. Gobler ${ }^{3}$ and Sonya T. Dyhrman ${ }^{2 \star}$

${ }^{1}$ MIT-WHOI Joint Program in Oceanography/Applied Ocean Science and Engineering, Cambridge, MA 02139, USA

${ }^{2}$ Woods Hole Oceanographic Institution, Biology Department, Woods Hole, MA 02543, USA. ${ }^{3}$ Stony Brook University, School of Marine and Atmospheric Sciences, Stony Brook, NY 11794, USA.

\section{Summary}

Long-SAGE (serial analysis of gene expression) was used to profile the transcriptome of the brown tide-forming alga, Aureococcus anophagefferens, under nutrient replete (control), and nitrogen $(\mathrm{N})$ and phosphorus $(P)$ deficiency to understand how this organism responds at the transcriptional level to varying nutrient conditions. This approach has aided $A$. anophagefferens genome annotation efforts and identified a suite of genes upregulated by $\mathrm{N}$ and $P$ deficiency, some of which have known roles in nutrient metabolism. Genes upregulated under $\mathrm{N}$ deficiency include an ammonium transporter, an acetamidase/formamidase and two peptidases. This suggests an ability to utilize reduced $\mathrm{N}$ compounds and dissolved organic nitrogen, supporting the hypothesized importance of these $\mathrm{N}$ sources in $\boldsymbol{A}$. anophagefferens bloom formation. There are also a broad suite of P-regulated genes, including an alkaline phosphatase, and two 5'-nucleotidases, suggesting $\boldsymbol{A}$. anophagefferens may use dissolved organic phosphorus under low phosphate conditions. These $\mathrm{N}$ - and P-regulated genes may be important targets for exploring nutrient controls on bloom formation in field populations.

\section{Introduction}

Aureococcus anophagefferens is a small ( $2 \mu \mathrm{m})$ eukaryotic phytoplankton responsible for the brown tide events

Received 26 April, 2010; accepted 16 August, 2010. *For correspondence. E-mail sdyhrman@whoi.edu; Tel. (+1) (508) 289 3608; Fax (+1) (508) 4572134 that have plagued many coastal ecosystems in the Eastern United States, most notably Long Island waters. Shortly after its discovery in 1985, it became evident that brown tide events were decimating the Long Island scallop industry and causing substantial losses to eelgrass habitat (Dennison et al., 1989; Greenfield and Lonsdale, 2002; Greenfield et al., 2004). This, combined with the regularity of blooms occurring in the Eastern United States, has led to $A$. anophagefferens becoming a widely studied harmful algal bloom (HAB) species (see reviews by Gobler et al., 2005 and Sunda et al., 2006).

Occurrences of HABs in coastal ecosystems have been commonly attributed to nutrient loading, whereby increased levels of nitrogen $(\mathrm{N})$ and phosphorus $(\mathrm{P})$ relieve algae from nutrient limitation (see review by Anderson et al., 2008). In contrast, A. anophagefferens often blooms in periods when concentrations of dissolved inorganic nitrogen (DIN) and dissolved inorganic phosphorus (DIP) are low. For example, blooms have been linked to low nitrate inputs resulting from variability in ground water flow (LaRoche et al., 1997). Mesocosm experiments during a natural bloom also showed enrichment with DIN and DIP inversely correlated with $A$. anophagefferens cel densities (Keller and Rice, 1989). Further experimental evidence shows a reduction of the relative abundance of $A$. anophagefferens within the phytoplankton community during DIN enrichment (Gobler and Sañudo-Wilhelmy 2001, Gobler et al., 2002; 2004; Kana et al., 2004).

Culture work has shown that $A$. anophagefferens can utilize $\mathrm{N}$ from a variety of organic compounds, including proteins, chitobiose and acetamide (Berg et al., 2002; Mulholland et al., 2002). These observations are supported by field studies indicating that natural assemblages of phytoplankton during brown tide events have the ability to use $\mathrm{N}$ from dissolved organic nitrogen (DON) such as amino acids and urea (Berg et al., 1997, 2003; Mulholland et al., 2002), and that $A$. anophagefferens has a higher affinity for reduced $\mathrm{N}$ (e.g. ammonium) and DON (e.g. urea and amino acids) than nitrate (Lomas et al., 1996; Mulholland et al., 2002; 2004). To date, there is only one study that has examined $\mathrm{N}$-regulated gene expression in $A$. anophagefferens. Using a quantitative RT-PCR approach on targeted genes involved in $\mathrm{N}$ transport and metabolism, it was demonstrated that $A$. anophagefferens upregulates a variety of genes, in response to acute $\mathrm{N}$ deficiency and

C 2010 Society for Applied Microbiology and Blackwell Publishing Lto 
growth on different $\mathrm{N}$ sources including transporters for nitrate, formate/nitrite, urea, ammonium and amino acids among others (Berg et al., 2008). Studies of $\mathrm{P}$ physiology are more limited. $A$. anophagefferens is capable of growing on dissolved organic phosphorus (DOP, e.g. glycerol-phosphate) as its sole $P$ source (Dzurica et al., 1989), but DOP metabolism in this group has not been comprehensively examined, either in culture studies or in the field. Further, there are no studies of functional genes related to $P$ physiology in this species.

When taken together, these studies indicate that A. anophagefferens may have the capacity to utilize reduced nitrogen, or organic nutrients when the concentration of inorganic nutrients becomes low. Phytoplankton have evolved mechanisms for efficiently scavenging $N$ and $P$ from a variety of sources and these mechanisms can be induced at the transcriptional level when a nutrient becomes limiting (Grossman, 2000; Dyhrman et al., 2006; 2008). Global transcriptome profiling studies have shown broad transcriptional regulation to nutrient deficiency in coccolithophores and diatoms (Dyhrman et al., 2006; Mock et al., 2008). This has also been seen in the HAB-forming species Alexandrium fundyense (Erdner and Anderson, 2006), and transcriptional studies are an increasingly popular tool for studies of HAB nutritional physiology (Dyhrman, 2008). There are a number of approaches for examining transcription in a non-targeted manner, ranging from microarrays (e.g. Mock et al., 2008) to next generation sequencing of cDNA (e.g. Erdner and Anderson, 2006). The Long-SAGE method used in this study is a sequencing-based approach, which avoids some of the challenges involved with microarrays, that infer abundance based upon hybridization, suffer from background noise, cross-hybridization problems and only measure relative abundance (Irizarry et al., 2005). An adaptation of the original SAGE method (Velculescu et al., 1995), Long-SAGE generates tag libraries without a priori knowledge of gene sequences via the detection of $21 \mathrm{bp}$ nucleotide sequence tags making it possible to evaluate the simultaneous expression patterns of many genes quantitatively (Saha et al., 2002). In this regard, Long-SAGE is similar to newer sequencing methods (digital gene expression and mRNA seq), but without the depth of coverage provided by advances in next generation sequencing capabilities (see review by Morozova et al., 2009). Long-SAGE tags are generated by the most $3^{\prime}$ Nla III restriction site on the transcript, and as a consequence, errors can be reduced by only considering tags mapping to the most $3^{\prime} \mathrm{Nla}$ III site of a gene. Long-SAGE has been useful for identifying transcriptome profiles for other algae, including the coccolithophore Emiliania huxleyi (Dyhrman et al., 2006) and the dinoflagellate Pfiesteria shumwayae (Coyne et al., 2004).
In this study, transcriptional responses of $A$. anophagefferens to $\mathrm{N}$ and $\mathrm{P}$ deficiency $(-\mathrm{N}$ and $-\mathrm{P})$ relative to a nutrient replete control were assayed to identify genes that $\boldsymbol{A}$. anophagefferens may upregulate when inorganic nutrients are depleted. These transcriptional responses were detected by mapping Long-SAGE tags to the 11510 gene models identified by in silico modelling of the A. anophagefferens whole genome sequence (http:// genome.jgi-psf.org/Auran1/Auran1.home.html). To our knowledge this is the first non-targeted transcriptional study in a Pelagophyte.

\section{Results}

Tag sampling and annotation

A total of 112000 tags were sampled, representing 31862 unique tags, from $A$. anophagefferens grown under $\mathrm{P}$-deficient $(-\mathrm{P}), \mathrm{N}$-deficient $(-\mathrm{N})$ and nutrient replete (control) conditions (Fig. 1). At this sampling depth, there is still a high rate of unique tag discovery (Fig. 2). All 31862 unique Long-SAGE tags were annotated by mapping to available $A$. anophagefferens expressed sequence tag (EST) or genomic sequences. Of these 31862 unique tags, 11847 (37.2\%) aligned to the genome with a $100 \%$ identical match to all $21 \mathrm{bp}$. A number of tags mapped to genes with annotations suggesting a role in $\mathrm{N}$ or $\mathrm{P}$ metabolism (Tables S1-S4).

\section{Differential regulation}

Aureococcus anophagefferens exhibited a broad transcriptional response to $\mathrm{N}$ and $\mathrm{P}$ deficiency, with 131 tags upregulated twofold or greater in $-\mathrm{P}, 56$ tags upregulated twofold or greater in $-\mathrm{N}, 34$ tags upregulated

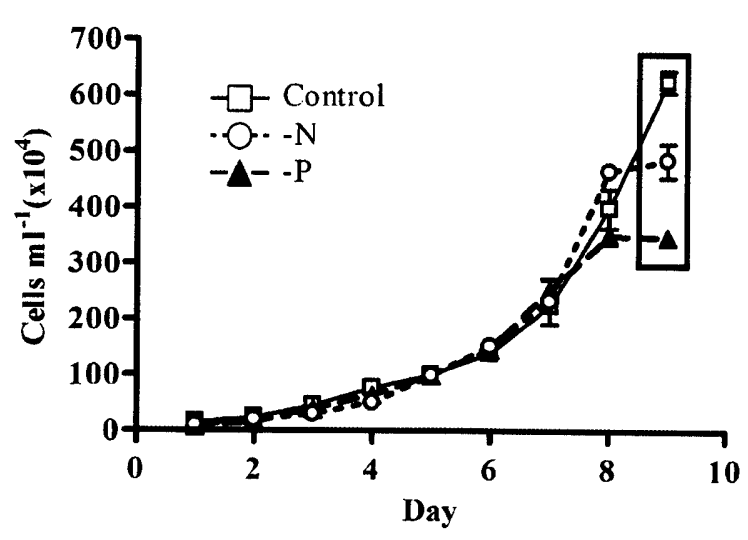

Fig. 1. Growth of $A$. anophagefferens under nutrient replete (control), phosphorus-deficient $(-P)$ and nitrogen-deficient $(-N)$ conditions. The treatments were harvested on day 9 (box). Error bars represent standard deviation of the mean for the control $(n=3),-\mathrm{N}$ and $-\mathrm{P}(n=2)$.

(c) 2010 Society for Applied Microbiology and Blackwell Publishing Ltd, Environmental Microbiology, 13, 468-481 
470 L. L. Wurch et al.

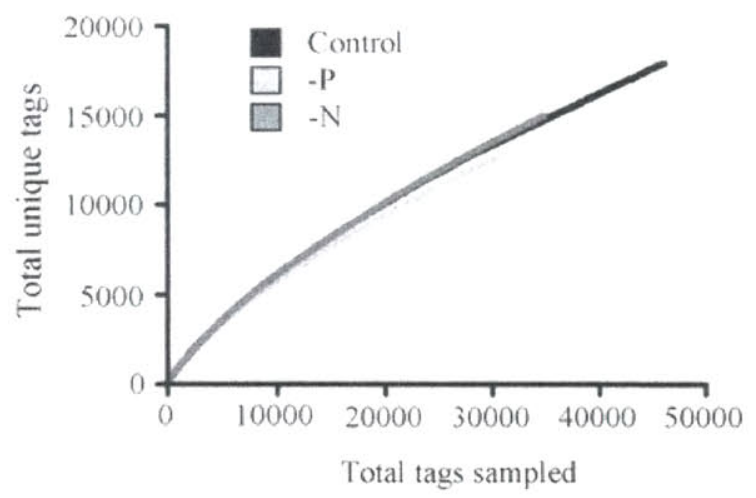

Fig. 2. Long-SAGE tag data plotted showing the relationship between total tags sampled in each library and the number of unique tags found. A predicted asymptote $(\sim 50000)$ was calculated by plotting the inverse of total tags sampled versus the inverse of unique tags and calculating the $y$-intercept.

twofold or greater in both $-\mathrm{P}$ and $-\mathrm{N}$, and 73 tags downregulated twofold or greater in both $-\mathrm{N}$ and $-\mathrm{P}$. A tag in a given treatment is considered upregulated (or downregulated) if it shows twofold or greater expression relative to both of the other libraries with an $R$-value $\geq 2$. In some cases, a tag was absent from one or more libraries, and is considered differentially regulated if the $R$-value $\geq 2$. The $R$-value is a log likelihood ratio statistic that scores tags by their deviation from the null hypothesis of equal frequencies given the tag sampling depth for each Long-SAGE library (Stekel et al., 2000). A complete list of these 294 differentially expressed tags is available in the Supporting Information (Tables S1-S4). Approximately $80 \%$ of differentially expressed tags could be mapped to available sequence data whereas $20 \%$ could not be aligned (Fig. 3 ). Of tags that mapped to the genome, $43 \%$ were aligned with gene models (Fig. 3). Roughly $49 \%$ of tags mapping to sequence data could not be assigned a function either because they aligned to: (i) ESTs or genome sequence representing hypothetical or predicted proteins, (ii) ESTs showing no database homology or (iii) genome sequence where no model is predicted (Tables S1-S4). Thus, approximately $31 \%$ of differentially expressed tags could be assigned a putative function (Tables 1-4).

Of 131 tags upregulated twofold or greater in the $-P$ treatment, many mapped to genes with putative functions in DIP and DOP acquisition (Tables 1 and S1). Tag 1819 mapped to a putative inorganic phosphate transporter, and showed an increase of almost sixfold in the $-\mathrm{P}$ library relative to the control library (Table 1 ). Two tags (6248 and 1817) mapped to two unique 5 '-nucleotidases. Tag 6248 was upregulated 4.7 -fold in the $-P$ library relative to the control library, and was upregulated 13.9-fold relative to the $-\mathrm{N}$ library (Table 1). Similarly, tag 1817 was upregulated 6.6 -fold in the $-P$ library relative to the control library, and was absent in the $-\mathrm{N}$ library (Table 1). Consistent with the upregulation of the putative $5^{\prime}$-nucleotidases, $A$. anophagefferens is able to grow on the nucleotide, adenosine monophosphate (AMP), as a sole $P$ source (Fig. 4). Tag 4828 mapped to an alkaline phosphatase and showed almost threefold upregulation relative to the control library and 6.4-fold upregulation relative to the $-\mathrm{N}$ library (Table 1). Other tags upregulated in the -P library mapped to a putative oxidoreductase, a nuclease, a transcription initiation factor, a variety of kinases and a phosphatase (Table 1).

Of 56 tags upregulated twofold or greater in the $-\mathrm{N}$ treatment, some mapped to genes involved in both DIN and DON metabolism (Tables 2 and S2). For example, tag 4223 mapped to an ammonium transporter and was upregulated 10 -fold in the $-\mathrm{N}$ library relative to the $-\mathrm{P}$ library and was absent from the control library (Table 2). Tag 3830 mapped to an acetamidase/ formamidase that was upregulated 11 -fold in the $-\mathrm{N}$ library relative to the $-\mathrm{P}$ library and was upregulated roughly twofold in the $-\mathrm{N}$ library relative to the control. Tag 17565 mapped to a xanthine/uracil/vitamin $\mathrm{C}$ permease and was only present in the $-\mathrm{N}$ library (Table 2). There were also tags that mapped to genes involved in protein metabolism, including two peptidases (tags 5832 and 3352), and an $\mathrm{N}$-acetylglucoasmine transferase (Tag 17579) (Table 2). Finally, a variety of tags showed upregulation in $-\mathrm{N}$ with less clear roles in $\mathrm{N}$ metabolism, including an arylsulfatase, phosphoglycerate dehydrogenase, a dynein heavy chain, and DNA-directed RNA polymerase.

There are 34 tags that can be considered to be related to a general stress response because they are

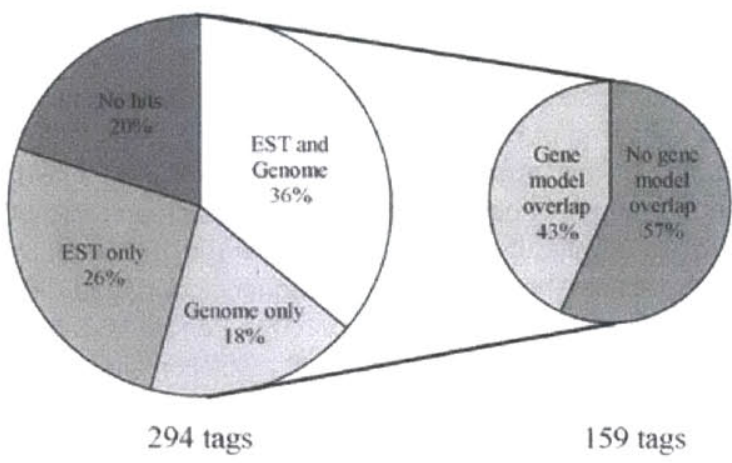

Fig. 3. The percentage of tags showing differential regulation (294 total tags) that map to available sequence data, and the percentage of tags that overlap with gene models from the subset of those tags that map to the $A$. anophagefferens genome (159 tags). See text for a description of the criteria a tag must meet to be considered differentially regulated. 
(1)

O Table 1. Successfully annotated tags showing upregulation in the $-\mathrm{P}$ library. Only tags that show greater than twofold change in the $-\mathrm{P}$ library relative to the control and $-\mathrm{N}$ libraries with an $R$-value $>2$ are included. ESTs are given for tags annotated by mapping to an EST. A protein ID is given for: (i) tags that map directly to the genome where a gene model exists or (ii) tags that map to an EST that overlaps with a gene model on the genome.

\begin{tabular}{|c|c|c|c|c|c|c|c|}
\hline \multirow[b]{2}{*}{ Tag ID } & \multirow[b]{2}{*}{ Tag sequence } & \multirow[b]{2}{*}{$R$-value } & \multicolumn{2}{|c|}{ Fold change versus: } & \multirow[b]{2}{*}{ Putative annotation } & \multirow[b]{2}{*}{ EST } & \multirow[b]{2}{*}{ Protein ID } \\
\hline & & & Control & $-\mathrm{N}$ & & & \\
\hline 1817 & CATGCCGGGCGCCTTCGACGC & 22.53 & 6.6 & Absent ${ }^{a}$ & $5^{\prime}$-nucleotidase (manually curated) ${ }^{b}$ & - & 21301 \\
\hline 1819 & CATGGGCGTCAAGCTCACGGC & 20.38 & 5.7 & Absent & Inorganic phosphate transporter (manually curated) & - & 22152 \\
\hline 157 & CATGGTGAAGTTGCAAAAGGC & 16.19 & 2.5 & 6.8 & NADP-dependent oxidoreductase [Hahella chejuensis KCTC 2396] & - & 67152 \\
\hline 1831 & CATGGCGCCCCTCGCCCGCGT & 10.09 & 4.8 & 4.4 & Endonuclease/exonuclease protein-like protein [Leishmania major] & - & 72478 \\
\hline 2957 & CATGGTCTCCGTCTITCACCC & 9.116 & 4.8 & 4.9 & ABC1-like [Oryza sativa Japonica Group] & - & 70922 \\
\hline 1922 & CATGGTCTGGGCCGGCGAGGG & 7.792 & 4.949 & 7.3 & Nucleoside diphosphate kinase Nm23-SD1 [Suberites domuncula] & - & 22626 \\
\hline 1833 & CATGGAGAACATCCACCGCGC & 7.194 & 3.4 & 27.9 & Mitochondrial substrate carrier family protein [Arabidopsis thaliana] & - & 22191 \\
\hline 1921 & CATGTCCCAGTTCATCCTCGC & 6.070 & Absent & 13.9 & $\begin{array}{l}\text { PREDICTED: similar to CG8472-PA, isoform A [Strongylocentrotus } \\
\text { purpuratus] }\end{array}$ & - & 72105 \\
\hline 1883 & CATGCGGGAGTCGCTAAGCTG & 5.601 & 4.4 & 3.0 & Beta transducin-like protein HET-E2C [Podospora anserina] & 4211177:40 & - \\
\hline 1972 & CATGACGACGACCACCACCAC & 4.928 & Absent & Absent & Peptidase [Salinibacter ruber DSM 13855] & 4205112:1 & - \\
\hline 2802 & CATGGACGCCGTCGACGCCGC & 4.928 & Absent & Absent & Pulvinus outward-rectifying channel for potassium SPOCK1 [Samanea saman] & 4205553:1 & - \\
\hline 1556 & CATGTAGACACCCCCCCCTCC & 4.593 & 3.1 & 2.1 & Dimethylaniline monooxygenase ( $\mathrm{N}$-oxide forming). & - & 29808 \\
\hline 1506 & CATGGACTACTGGCTCCTCGG & 4.451 & 2.9 & 4.6 & Cathepsin L [Theromyzon tessulatum] & 4209574:1 & - \\
\hline 2385 & CATGATCGCCGCGCTGCGGCC & 4.402 & 2.6 & 19.3 & Fucokinase, isoform CRA_d [Homo sapiens] & 4217517:1 & - \\
\hline 4828 & CATGGACGCGGCCGTCAAGCG & 4.224 & 2.9 & 6.4 & Alkaline phosphatase-like protein [Teredinibacter turnerae T7901] & 4205689:1 & - \\
\hline 136 & CATGTACATACATCGCACATT & 4.017 & 5.3 & Absent & $\begin{array}{l}\text { BRF1 homolog, subunit of RNA polymerase III transcription initiation factor } \\
\text { IIIB [Danio rerio] }\end{array}$ & 71825 & - \\
\hline 1879 & CATGCCCTCGACGCCGCAGCG & 3.689 & 9.5 & 7.0 & $\begin{array}{l}\text { Chain A, 4ank: A Designed Ankyrin Repeat Protein With Four Identical } \\
\text { Consensus Repeats }\end{array}$ & 4209777:1 & - \\
\hline 1595 & CATGGACTCCGTCAAGCGCGG & 3.579 & 4.9 & Absent & Glycosyl transferase, group 1 & - & 60545 \\
\hline 6248 & CATGGGCGCGCTCCGCGCCGT & 3.467 & 4.7 & 13.9 & $5^{\prime}$-nucleotidase (manually curated) & - & 28588 \\
\hline 1917 & CATGCGCGCGCAGATCTGCGA & 3.125 & 3.7 & 4.8 & Protein kinase-like [Medicago truncatula] & 4211177:384 & - \\
\hline 14815 & CATGGCAAGATTGTGGTTCCT & 2.962 & 13.1 & 9.7 & Glycoside hydrolase (manually curated) & - & 64125 \\
\hline 2371 & CATGTCCACGCCGCAGCTCCG & 2.939 & 5.3 & 11.8 & $A B C$ transporter (manually curated) & - & 62521 \\
\hline 2034 & CATGATCATCTCGCCGTCGTC & 2.738 & Absent & Absent & PHD-finger family protein [Trichomonas vaginalis G3] & EH117526 & - \\
\hline 3008 & CATGGCCTGCTACCGGGGCCA & 2.738 & Absent & Absent & $\begin{array}{l}\text { PREDICTED: similar to ankyrin 2,3/unc44, partial [Strongylocentrotus } \\
\text { purpuratus] }\end{array}$ & EH117401 & - \\
\hline 1904 & CATGGCGTCGGGCTACGGCCC & 2.531 & 5.1 & Absent & $\begin{array}{l}\text { Twin-arginine translocation pathway signal sequence domain protein, putative } \\
\text { [Phaeobacter gallaeciensis } 2.10]\end{array}$ & 4205643:1 & - \\
\hline 1957 & CATGGAGTAGATCCACCCGTC & 2.504 & 3.5 & 3.6 & $\begin{array}{l}\text { Serine/threonine-protein kinase ripk4, putative [Penicillium marneffei ATCC } \\
\text { 18224] }\end{array}$ & 4206124:1 & \\
\hline 1929 & CATGCTCATCGCCTGCGTCGT & 2.463 & 3.3 & 4.3 & Synaptobrevin domain-containing protein [Dictyostelium discoideum AX4] & - & 36201 \\
\hline 2817 & CATGGCAAATCCTGCCAAGGT & 2.454 & 6.6 & 9.7 & Mitogen-activated protein kinase 2 [Toxoplasma gondii] & - & 55052 \\
\hline 3045 & CATGAAGGCGCCGTAGCTGCC & 2.433 & 5.3 & 5.9 & Flagellar associated protein [Chlamydomonas reinhardti] & EH117555 & - \\
\hline 1869 & CATGTCCAACCGCAAGTAGCT & 2.366 & Absent & 3.2 & Type I fatty acid synthase, putative [Toxoplasma gondii RH] & - & 72815 \\
\hline 14836 & CATGCGCCTCTCGTACTACGG & 2.190 & Absent & Absent & OTU-like cysteine protease family protein [Tetrahymena thermophila] & 4208711:1 & \\
\hline 14902 & CATGGACGCGTACGATTTGGT & 2.190 & Absent & Absent & Trehalose-phosphatase (manually curated) & - & 53568 \\
\hline 14850 & CATGTACGTCGGCGAGGGCGG & 2.081 & Absent & 5.4 & Cellulase, endoglucanase (manually curated) & - & 12783 \\
\hline 279 & CATGCCGCCGACGACGCGGTC & 2.019 & 2.5 & 2.3 & PREDICTED: similar to coiled-coil domain containing 93 [Ciona intestinalis] & 4206222:1 & - \\
\hline
\end{tabular}

a. Fold change cannot be calculated on tags absent from a given library, but are included in the table with $R$-value $>2$.

b. Manually curated notes the gene model was manually assigned a function and reviewed by a curator. 
Table 2. Successfully annotated tags showing upregulation in the $-\mathrm{N}$ library. Only tags that show greater than twofold change in the $-\mathrm{N}$ library relative to the control and $-\mathrm{P}$ libraries with an $R$-value $>2$ are included. A protein ID is given for: (i) tags that map directly to the genome where a gene model exists or (ii) tags that map to an EST that overlaps with a gene model on the genome. ESTs are given for tags annotated by mapping to an EST.

\begin{tabular}{|c|c|c|c|c|c|c|c|}
\hline \multirow[b]{2}{*}{$\operatorname{Tag} 10$} & \multirow[b]{2}{*}{ Tag sequence } & \multirow[b]{2}{*}{$R$-value } & \multicolumn{2}{|c|}{ Fold change versus: } & \multirow[b]{2}{*}{ Putative annotation } & \multirow[b]{2}{*}{ EST } & \multirow[b]{2}{*}{ Protein ID } \\
\hline & & & Control & $-P$ & & & \\
\hline 4223 & CATGGACGACTCGAAGCACGG & 4.742 & Absent ${ }^{a}$ & 10.3 & Ammonium transporter (manually curated) & - & 52202 \\
\hline 11372 & CATGTATCCCCTGAGAACTGG & 3.159 & 6.1 & Absent & Dynein-1-beta heavy chain, flagellar inner arm I1 complex [Chlamydomonas reinhardti] & - & 72661 \\
\hline 3447 & CATGGCCGACGCGGGCGAGGT & 2.892 & 5.9 & 6.1 & DEAD (Asp-Glu-Ala-Asp) box polypeptide 46 [G. gallus] & - & 65005 \\
\hline 5832 & CATGACGAAGTAGTACTTGCC & 2.772 & 5.4 & 3.0 & Peptidase [Salinibacter ruber DSM 13855] & EH117491 & - \\
\hline 2091 & CATGGGCCCCCACGAGCGCGA & 2.643 & 3.6 & 5.0 & D-3-phosphoglycerate dehydrogenase [Thalassiosira pseudonana CCMP1335] & 4211036:1 & - \\
\hline 17565 & CATGCTCTTCCACCTCGGCCT & 2.586 & Absent & Absent & Xanthine/uracil/vitamin C permease [Micromonas sp. RCC299] & - & 52593 \\
\hline 17581 & CATGGAGCTCTGGCTCGCCGC & 2.586 & Absent & Absent & Arylsulfatase (manually curated) & - & $64446^{c}$ \\
\hline 3890 & CATGGTCGGCTACGGTGGCGG & 2.426 & 3.2 & 6.5 & Pherophorin-dz1 protein [Volvox carteri f. nagariensis] & 4210976:3 & - \\
\hline 6403 & CATGCATCACTITGGACTAAT & 2.358 & 2.7 & Absent & $\begin{array}{l}\text { DNA-directed RNA polymerase II } 135 \mathrm{kDa} \text { polypeptide, putative, expressed } \\
\text { [Oryza sativa (japonica cultivar-group)] }\end{array}$ & - & 38738 \\
\hline 3830 & CATGTCGATAGAATCCAATGG & 2.291 & 2.3 & 11.2 & Acetamidase/formamidase (manually curated) & - & 37987 \\
\hline 3345 & CATGCAGGCCGTCGGTCTCTG & 2.238 & 2.0 & 11.2 & NADPH protochlorophyllide reductase [Bigelowiella natans] & 4207500:1 & - \\
\hline 3352 & CATGGGCCCCGGCCGCCGCCG & 2.121 & & Absent & Peptidase M16A, coenzyme PQQ biosynthesis protein PqqF [Medicago truncatula] & - & 22177 \\
\hline 17579 & CATGTTCTCCGCGTCGTGGCT & 2.069 & Absent & Absent & O-linked $\mathrm{N}$-acetylglucosamine (GlcNAc) transferase [Danio rerio] & - & 32337 \\
\hline 5046 & CATGAAGGTGGCCGAGGCCCT & 2.003 & 2.1 & 10.3 & Poly A binding protein, cytoplasmic 1 a [Danio rerio] & - & 70409 \\
\hline
\end{tabular}

a. Fold change cannot be calculated on tags absent from a given library, but are included in the table with $R$-value $>2$.

c. Tanually curated notes the gene model was manually assigned a function and reviewed by a curator.

$\frac{\mathrm{m}}{\mathrm{O}}$

Table 3. Successfully annotated tags showing greater than twofold upregulation in both the $-\mathrm{N}$ and $-\mathrm{P}$ libraries relative to the control library $(R$-value $>2)$. A protein $I D$ is given for: (i) tags that map directly to the genome where a gene model exists or (ii) tags that map to an EST that overlaps with a gene model on the genome. ESTs are given for tags annotated by mapping to an EST.

\begin{tabular}{|c|c|c|c|c|c|c|c|}
\hline \multirow[b]{2}{*}{ Tag ID } & \multirow[b]{2}{*}{ Sequence } & \multirow[b]{2}{*}{$R$-value } & \multicolumn{2}{|c|}{ Fold change for: } & \multirow[b]{2}{*}{ Putative annotation } & \multirow[b]{2}{*}{ EST } & \multirow[b]{2}{*}{ Protein ID } \\
\hline & & & $-P$ & $-\mathrm{N}$ & & & \\
\hline 1814 & CATGATGGGCGTCACGGGCGC & 15.58 & 4.8 & 3.2 & Chloroplast light harvesting protein isoform 3 [/sochrysis galbana] & - & 59955 \\
\hline 10695 & CATGGAGGAGGTCAACCTCCT & 3.940 & 14.6 & 17.6 & Contains oxidoreductase domain & - & 72519 \\
\hline 2687 & CATGTTCGGCGAGGGCCAGAC & 3.834 & 4.4 & 2.7 & Plastid light harvesting protein isoform 39 (manually curated) ${ }^{\mathrm{a}}$ & - & 77828 \\
\hline 922 & CATGCCGGCGGCCGTGCCGGG & 3.401 & 3.6 & 3.9 & $\begin{array}{l}\text { Fucoxanthin chlorophyll a/c protein, deviant [Phaeodactylum tricornutum } \\
\text { CCAP 1055/1] }\end{array}$ & 4208996:1 & - \\
\hline 1894 & CATGCTCGGGCTCGCGCACGC & 3.327 & 7.8 & 3.6 & Glycosyl transferase group 1 [Herpetosiphon aurantiacus ATCC 23779] & 4211177:45 & - \\
\hline 1481 & CATGGCCCGCAGCGACCTCCA & 3.276 & 2.3 & 5.4 & Sensory transduction histidine kinase [Psychroflexus torquis ATCC 700755] & - & 71871 \\
\hline 1839 & CATGCCCGACTACACCAAGTC & 3.041 & 3.4 & 2.0 & $\begin{array}{l}\text { Oxidoreductase, acting on the aldehyde or oxo group of donors, disulfide as } \\
\text { acceptor/pyruvate dehydrogenase (acetyl-transferring) [Arabidopsis thaliana] }\end{array}$ & - & 53060 \\
\hline 1951 & CATGTTCCTGTCGCTCGACGT & 3.026 & 16.0 & 6.8 & Cation efflux system protein [Oceanicola batsensis HTCC2597] & 4211177:393 & - \\
\hline 6839 & CATGGTCGGCGGCATCGACGA & 3.026 & 16.0 & 6.8 & RecName: Full = ATP synthase subunit beta, mitochondrial; Flags: Precursor & 4206114:1 & \\
\hline 3296 & CATGCCGACGCCGCGCGCGCT & 2.610 & Absent ${ }^{b}$ & Absent & $\begin{array}{l}\text { PREDICTED: similar to dishevelled associated activator of morphogenesis } 1 \\
\text { isoform } 1 \text { [Danio rerio] }\end{array}$ & - & 70943 \\
\hline 1941 & CATGTGGATGCAAGCGGCTGC & 2.580 & 3.3 & 3.7 & Glutaminyl-tRNA synthetase, putative [Perkinsus marinus ATCC 50983] & 4211177:152 & - \\
\hline 2546 & CATGGCGCGGTACCAGATCGG & 2.057 & 7.3 & 2.7 & O-methyltransferase, putative [Streptomyces ghanaensis ATCC 14672] & 4211177:220 & - \\
\hline
\end{tabular}

$\Phi$ a. Manually curated notes the gene model was manually assigned a function and reviewed by a curator.

b. Fold change cannot be calculated on tags absent from a given library, but are included in the table with $R$-value $>2$. 


\begin{tabular}{|c|c|c|c|c|c|c|c|}
\hline \multirow[b]{2}{*}{ Tag ID } & \multirow[b]{2}{*}{ Tag sequence } & \multirow[b]{2}{*}{$R$-value } & \multicolumn{2}{|c|}{ Fold change in: } & \multirow[b]{2}{*}{ Putative annotation } & \multirow[b]{2}{*}{ EST } & \multirow[b]{2}{*}{ Protein ID } \\
\hline & & & $-\mathbf{P}$ & $-N$ & & & \\
\hline 2 & CATGGTCCTCCGCCTCCGCGG & 11.54 & -2.5 & -2.4 & Polyubiquitin [Trichomonas vaginalis] & - $\quad-\quad$ r & 17856 \\
\hline 184 & CATGTAGGACGGACACGTAAG & 10.06 & -5.4 & -3.7 & Phosphoribosylaminoimidazole carboxylase, Candida glabrata & 4213887:1 & - \\
\hline 257 & CATGAGCTCCCGGCTGCGGGC & 3.971 & -3.8 & -5.2 & ATP-dependent Clp protease proteolytic subunit [Cyanidioschyzon merolae] & 4206479:1 & - \\
\hline 216 & CATGGGCGACGCCGTCGCCGC & 3.932 & -12.4 & -6.6 & 3-isopropylmalate dehydrogenase [Synechococcus elongatus PCC 6301] & EH412414 & - \\
\hline 187 & CATGTAGGCGCGCCCGCGCGT & 3.846 & -6.2 & -3.3 & Methionine sulfoxide reductase A [Synechococcus sp. WH 5701] & - & 59179 \\
\hline 1516 & CATGTCCTGCAAGAAGGACAC & 3.604 & -5.7 & -3.7 & Eukaryotic translation initiation factor 5A [Micromonas pusilla CCMP1545] & - & 59757 \\
\hline 80 & CATGGTGAAGATCCCCCAGGC & 3.600 & Absent $^{\mathrm{a}}$ & -8.8 & Lipocalin [Pelobacter propionicus DSM 2379] & 4212868:1 & - \\
\hline 53 & CATGGCCTAAAAAAAAAATAA & 3.251 & Absent & -8.1 & RS1, ribosomal protein $1[$ Thalassiosira pseudonana] & 4211021:1 & - \\
\hline 3728 & CATGGGGCTCTACGTCTACGG & 3.213 & Absent & -2.0 & $\begin{array}{l}\text { Anthranilate phosphoribosyltransferase, chloroplast precursor putative, expressed } \\
\text { [Oryza sativa (japonica cultivar-group)] }\end{array}$ & 4206546:1 & - \\
\hline 4679 & CATGCTTAAAGAACTAATATA & 2.927 & -11.0 & -3.9 & PREDICTED: similar to ferredoxin-NADP reductase [Ornithorhynchus anatinus] & 4211085:1 & - \\
\hline 4690 & CATGGAGGGCGAGAAGATCGC & 2.900 & -3.8 & Absent & Eukaryotic translation initiation factor 2 subunit $3, X$-linked [Mus musculus] & - & 22992 \\
\hline 240 & CATGTACTCCTAGAGGGTGCA & 2.896 & -2.1 & Absent & RAD23 [Phaeodactylum tricornutum CCAP 1055/1] & 4216537:1 & \\
\hline 144 & CATGGCGCCGTATCAATAGCG & 2.857 & -2.5 & -2.1 & Protein kinase NPK2 [Nicotiana tabacum] & - & 72184 \\
\hline 367 & CATGACGACGCCGGGCAGCCC & 2.730 & -5.5 & -5.9 & Proteophosphoglycan 5 [Leishmania major strain Friedlin] & 4206526:2 & - \\
\hline 122 & CATGGACCTCAACCAGGTCAA & 2.691 & Absent & Absent & Replication factor A [Capsicum chinense] & 4216955:1 & - \\
\hline 468 & CATGCGCGACGAGTTCCACGT & 2.642 & -10.3 & -3.7 & Aspartate aminotransferase [Phaeodacty/um tricornutum CCAP 1055/1] & 4214969:2 & - \\
\hline 4707 & CATGGCGCCGGACTACGTCGA & 2.520 & Absent & -2.0 & 1 origin recognition complex subunit 2 [Oryza sativa] & 4212823:1 & - \\
\hline 3028 & CATGCACGGCTGATGAGCCCC & 2.437 & -2.3 & Absent & ABC transporter [Thalassiosira pseudonana CCMP1335] & 4210715:1 & - \\
\hline 707 & CATGGGCTACAACGGCGGCAC & 2.331 & -5.5 & -3.9 & Light-inducible protein atls 1 , putative [Ricinus communis] & $4215630: 1$ & - \\
\hline 996 & CATGGAGGACGAGGGGCGATG & 2.307 & Absent & Absent & Lipase/esterase [Synechococcus sp. CC9311] & - & 70850 \\
\hline 4919 & CATGCGGCGCGGCGCGGCGGC & 2.307 & Absent & Absent & Centrin, putative [Plasmodium falciparum 3D7] & 4211177:12 & - \\
\hline 4890 & CATGTGCAAGAAGCCCGGCTG & 2.260 & -5.5 & Absent & Putative GTP-binding protein typA [Oryza sativa] & - & 52055 \\
\hline 375 & CATGACGGACCTCCGCGACAA & 2.229 & Absent & -5.9 & Malate/L-lactate dehydrogenase (manually curated) ${ }^{b}$ & 4211088:1 & \\
\hline 4684 & CATGATGATCGAATGATCCAC & 2.156 & -9.6 & -2.6 & Nitrite reductase (manually curated) & - & 37238 \\
\hline 4697 & CATGCGTGTCTACCCGGCCGC & 2.106 & -8.2 & -4.4 & Nitrate transporter (manually curated) & - & 60332 \\
\hline 4807 & CATGTACCTCAAGCAGGACTC & 2.081 & Absent & -2.2 & DNA ligase I [Coprinopsis cinerea] & - & 36790 \\
\hline 110 & CATGGACTAAAATTGATCACA & 2.058 & -5.5 & -2.9 & Elongation factor 1B-gamma, putative/eEF-1B gamma, putative [Arabidopsis thaliana] & 4210815:1 & - \\
\hline 131 & CATGGCCGCGGCCATCGGCGT & 2.015 & -3.8 & -2.3 & F-ATPase family transporter: protons (mitochondrial) [Ostreococcus lucimarinus CCE9901] & 4206441:1 & - \\
\hline
\end{tabular}

a. Fold change cannot be calculated on tags absent from a given library, but are included in the table with $R$-value $>2$.

b. Manually curated notes the gene model was manually assigned a function and reviewed by a curator. 


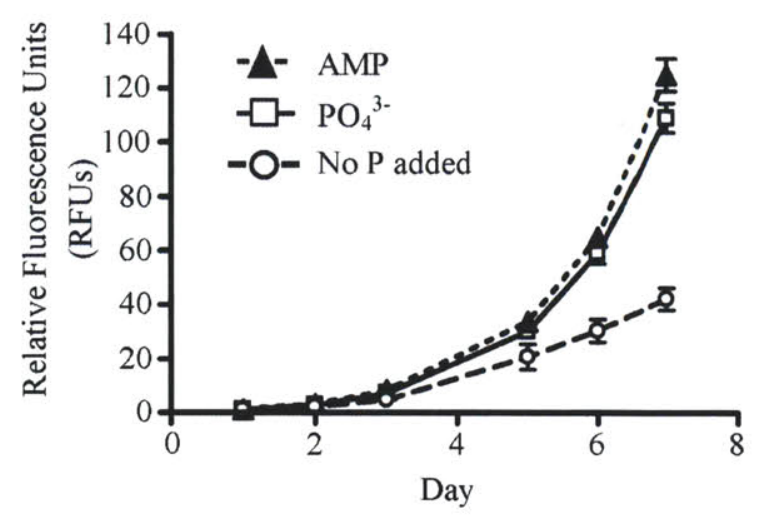

Fig. 4. Growth of $A$. anophagefferens on different $\mathrm{P}$ sources: $50 \mu \mathrm{M}$ phosphate $\left(\mathrm{PO}_{4}{ }^{3-}\right), 50 \mu \mathrm{M}$ AMP and a no $\mathrm{P}$ added control. RFUs (Relative Fluorescence Units) serve as a proxy for biomass. Error bars represent standard errors of the mean $(n=3)$.

upregulated in both $-\mathrm{P}$ and $-\mathrm{N}$ relative to the control (Table S3). Two tags (10695 and 1839) mapped to two different oxidoreductases (Table 3). Tag 10695 showed strong upregulation in both $-\mathrm{P}$ (14.6-fold) and $-\mathrm{N}$ (17.7fold) relative to the control (Table 3). Tag 1839 also showed upregulation in both $-\mathrm{P}$ and $-\mathrm{N}$, with a threefold increase in $-\mathrm{P}$ and twofold increase in $-\mathrm{N}$ relative to the control (Table 3). Additionally, three tags (1814, 2687 and 922) mapped to three different proteins involved in light harvesting, with all three tags showing similar magnitudes of upregulation (Table 3).

The final category contains tags that were downregulated in both $-\mathrm{N}$ and $-\mathrm{P}$, which consists of 73 tags (Table S4). This may also be the result of a general stress response. Tags in this category were downregulated twofold or greater in the $-\mathrm{P}$ and $-\mathrm{N}$ libraries relative to the control with an $R$-value $\geq 2$. Two tags mapped to genes with known roles in DIN metabolism. Tag 4684 mapped to a nitrite reductase while tag 4697 mapped to a nitrate transporter (Table 4). Also in this category is tag 2, a highly expressed tag that mapped to polyubiquitin, and other tags that mapped to genes related to general metabolism (Table 4).

Some tags mapped to genes with known roles in $\mathrm{N}$ and $\mathrm{P}$ metabolism, but did not meet the criteria for differential regulation. For example, tag 113 mapped to a putative urea transporter and shows similar expression in the $-\mathrm{N}$ and control, compared with a depressed signal under $-\mathrm{P}$ (data not shown). Other tags that mapped to genes with known roles in nutrient metabolism included, but are not limited to, a variety of $\mathrm{N}$ substrate transporters, nitrate reductase, and urease (Fig. 5).

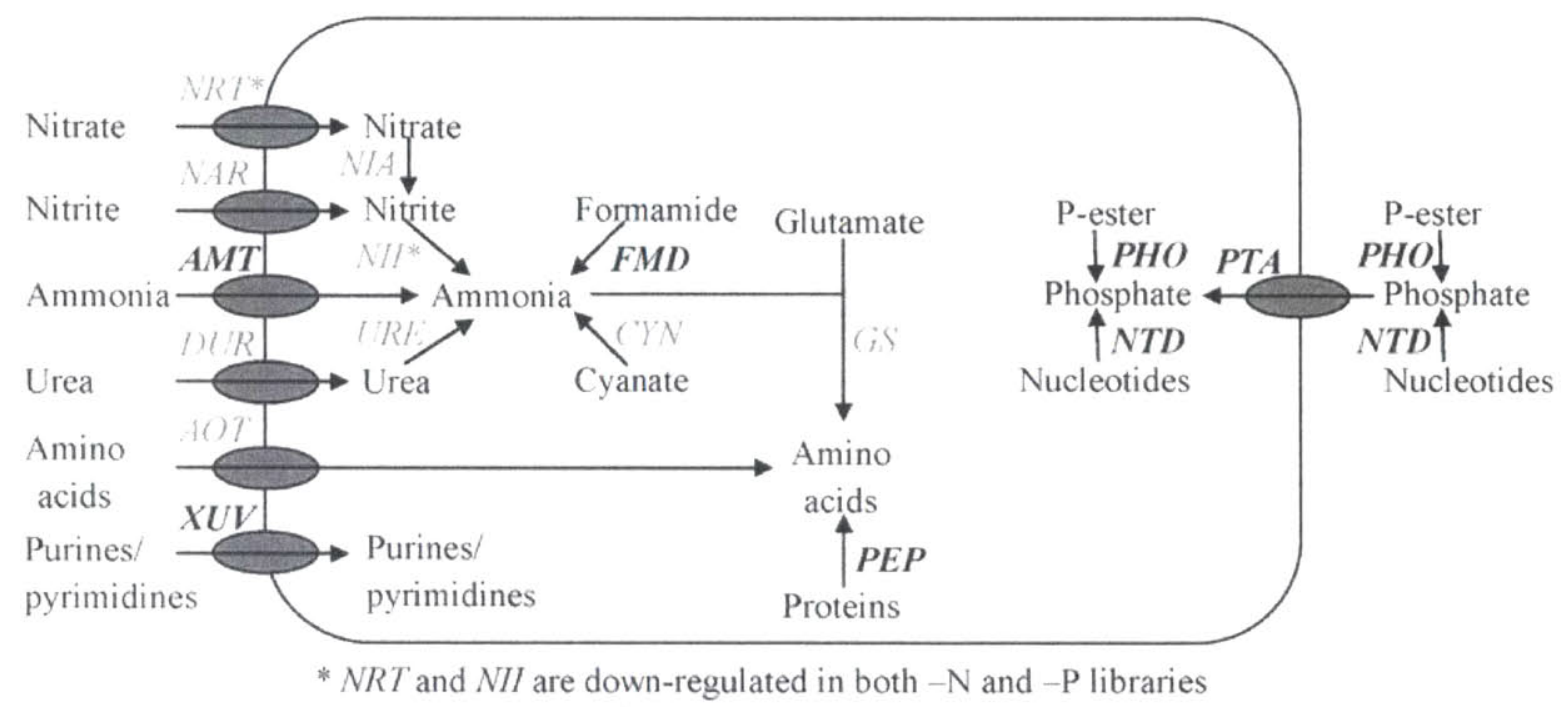

Fig. 5. Schematic of $\mathrm{N}$ and $\mathrm{P}$ acquisition/metabolism genes identified in $A$. anophagefferens with Long-SAGE data. Putative $\mathrm{N}$-related transporter localizations are based upon a previous study (Berg et al., 2008). Localizations of P-related genes are for clarity of the figure only. Genes are in italics, with bold indicating the presence of a tag that is upregulated in either the nitrogen-deficient (-N) or phosphorus-deficient (-P) library. AMT, FMD, XUV and PEP are upregulated in the $-\mathrm{N}$ library while PHO, NTD and PTA are upregulated in the $-\mathrm{P}$ library. NRT and $\mathrm{NII}$ are downregulated in both $-\mathrm{N}$ and $-\mathrm{P}$ libraries. Other expressed genes include NAR (tag 381: CATGGTCCTCAACGACGCGAC), NIA (tag 11818: CATGTAATTCACGAAGGTCGG), DUR (tag 113: CATGCTAACTTGTATAATAAT), URE (tag 2023: CATGGTCCTCAACGACGCGAC), AOT (tag 31113: CATGTCGCTGACGGGCAACGT), CYN (tag 2141: CATGCGCCGCCAGTAGCGGGT) and GS (tag 18182: CATGTCCTGCAACCCCTACCT). Gene names are as follows: NRT, nitrate transporter; NAR, formate/nitrite transporter; AMT, ammonium transporter; DUR, urea transporter; $A O T$, amino acid transporter; XUV, xanthine/uracil/vitamin C transporter; NIA, nitrate reductase; NII, nitrite reductase; URE, urease; $F M D$, acetamidase/formamidase; $C Y N$, cyanase; GS, glutamine synthetase; $P E P$, peptidase; $P H O$, phosphatase/alkaline phosphatase; NTD, 5'-nucleotidase; PTA, phosphate transporter. 


\section{Discussion}

As a consequence of its devastating effects to the coastal ecosystem and commercial shellfishing industries, $A$. anophagefferens has become a widely studied HAB species (as reviewed in Gobler et al., 2005; Sunda et al., 2006). Nutrient supply is considered an important factor that may drive brown tide dynamics, and it is hypothesized that $A$. anophagefferens will use reduced $\mathrm{N}$ and DON under nitrate-deficient conditions. A. anophagefferens may also switch to growth on DOP under phosphate-deficient conditions. In this study, Long-SAGE was used to profile the $A$. anophagefferens transcriptome under $\mathrm{N}$ - and $\mathrm{P}$-deficient and nutrient replete (control) conditions with the goal of gaining a better understanding of the molecular mechanisms underlying $\mathrm{N}$ and $\mathrm{P}$ metabolism in $A$. anophagefferens and to examine molecular level evidence of switching from growth on inorganic nutrients to growth on organic matter at the onset of nutrient deficiency.

\section{Long-SAGE and genome annotation}

Here, 31862 unique Long-SAGE tags have been identified and $11847(37.2 \%)$ of these tags mapped to the genome. As previously reviewed, these results are consistent with other Long-SAGE studies where on average, $36.5 \%$ of Long-SAGE tags can be mapped to the genome if it is available (Wang, 2007). This may be explained by the fact that an exact match between the tag and genomic sequence is required, and there is most likely variation in the genomes of individual organisms, even of the same strain. Furthermore, if a tag is located at an intron/exon boundary, it will not map back to the genome. An individual tag may also map to multiple sites if two different genes have the same most $3^{\prime} \mathrm{Nla}$ III restriction site and downstream sequence. A total of 1045 (or $8.8 \%$ ) of tags hit multiple sites, and were excluded from further analysis.

Despite these limitations and the fact that this study only covered a fraction of the transcriptome, these expression data have enhanced the $A$. anophagefferens genome annotation effort by assigning expression data to many genes, supporting in silico gene calls, and locating regions where genes may exist, but were not otherwise identified. For example, tag 1819 mapped to the genome in a location where both an EST and a gene model exist. In this example, expression data have been successfully assigned to this gene model, and the tag was successfully annotated as an inorganic phosphate transporter. Alternatively, Tag 1817 mapped to the genome in a location where a gene has been predicted (putative 5'-nucleotidase), but no EST support is available. In this case, the Long-SAGE tag has provided support for the in silico gene model prediction, and an annotation has been assigned to the tag. As a final example, tag 14821 mapped to the genome where no gene model exists, and is located too far from the nearest gene model to be part of the $3^{\prime}$ untranslated region. This tag is found eight times exclusively in the $-P$ library. This is a case where tag data have provided evidence for the existence of a gene that was not otherwise identified.

The Long-SAGE resulted in roughly 30000 unique tags, and predicts the unique tag yield to be about 50000 based on the frequency of unique tag recovery. If only one unique tag was sampled from every transcript, this would result in a transcriptome size of 50000 genes, higher than the 11510 gene models identified with in silico modelling with the genome sequence (http://genome.jgi-psf.org/ Auran1/Auran1.home.html). However, transcriptome size estimates are often substantially elevated with LongSAGE data because multiple unique tags can be generated for the same transcript at non-primary Nla III sites with incomplete restriction digests during library construction. This is likely the primary reason for the inflated gene number estimated here. However, this discrepancy is not entirely due to incomplete digestion, as tags (e.g. tag 14821 ) mapped to the genome in regions where there was no gene model prediction. In Thalassiosira pseudonana, a tiling array (that is not restricted to the assumptions about gene content that is the case for traditional microarrays) identified 1132 transcripts that were not present in the 11390 modelled gene set (Mock et al., 2008). Here, Long-SAGE is similar in the ability to identify putative genes that were not detected with in silico gene modelling for the genome sequence, which highlights the value of these data types in supporting genome annotation efforts. Even with the relatively low depth of sampling in this study, it is apparent that highly expressed genes detectable in a low resolution dataset are missing from the gene models predicted in the $A$. anophagefferens genome. With advances in sequencing technology, it is becoming possible to perform large-scale short-read sequencing of the transcriptome with exceptionally high coverage, and decreasing cost. The application of these techniques will be valuable for helping to support future genome annotation efforts as well as discovering novel genes (Morozova et al., 2009).

\section{Responses to $P$ deficiency}

A strong transcriptional response was observed in the $-P$ library. A number of these -P tags mapped to genes with known roles in both inorganic and organic $P$ metabolism. One of the most highly P-regulated tags $(R$-value $>20)$ mapped to a putative inorganic phosphate transporter. This would suggest that one strategy employed by $A$. anophagefferens during $\mathrm{P}$ deficiency is to produce more phosphate transporters, or switch to a more efficient one. 
This strategy has been observed in other eukaryotic algae (Chung et al., 2003; Dyhrman et al., 2006).

Two tags (6248 and 1817) upregulated in the $-P$ library mapped to two different $5^{\prime}$-nucleotidases. This enzyme cleaves phosphorus from nucleotides and has been suggested to be involved in P-scavenging from exogenous nucleotides in other eukaryotic algae (Flynn et al., 1986; Dyhrman and Palenik, 2003). In the ocean, nucleotides can be released from cells by grazing or lysis and may represent a major source of $P$, with concentrations reaching 10-20 nM (Ammerman and Azam, 1985). A. anophagefferens can grow well on AMP as its sole $P$ source, indicating that nucleotides may be an important $P$ source for field populations. Although both of the tags mapping to the $5^{\prime}$-nucleotidase are generally upregulated in the $-P$ library, the intensity and pattern of their regulation is distinct and they could be serving different functions within the cell.

Tag 4828 is significantly upregulated in the -P library and mapped to an EST that aligns with a gene model for alkaline phosphatase in the $A$. anophagefferens genome. This enzyme is known to cleave phosphorus from a variety of DOP compounds and has been shown to be induced under $P$ limitation in other algae (Dyhrman and Palenik, 1999; 2003; Landry et al., 2006; Xu et al., 2006). Algal alkaline phosphatases can be difficult to identify, for example the $E$. huxleyi alkaline phosphatase (Landry et al., 2006; Xu et al., 2006) has no database homology. The putative $A$. anophagefferens alkaline phosphatase is similar to the alkaline phosphatase identified in the $T$. pseudonana genome.

The presence and upregulation of tags mapping to genes related to DOP hydrolysis suggests that $A$. anophagefferens has the ability to utilize P-ester (especially 5 -nucleotides) and perhaps other DOP compounds when DIP is low. This hypothesis is consistent with field observations of significant reductions in DOP concentration during the peak of brown tides, when $A$. anophagefferens cell densities exceed $10^{6}$ cells $\mathrm{ml}^{-1}$ in New York estuaries (Gobler et al., 2004). Given the lack of studies on $A$. anophagefferens $\mathrm{P}$ physiology, these observations warrant further investigation using a semi-continuous or continuous culture study to differentiate short-term responses to $P$ deficiency, examined herein, from the long-term acclimation strategies that may be more indicative of natural populations.

\section{Responses to $\mathrm{N}$ deficiency}

Under N-deficient conditions, $\boldsymbol{A}$. anophagefferens upregulates a number of genes putatively involved in $\mathrm{N}$ acquisition. Tag 4223 is upregulated 15 -fold in the $-\mathrm{N}$ library and mapped to an EST that shows sequence homology to characterized ammonium transporters in the diatom Cylin- drotheca fusiformis. The ammonium transporters in $C$. fusiformis are transcriptionally regulated, with highest mRNA copies in N-deficient cells (Hildebrand, 2005), consistent with the pattern observed herein. $A$. anophagefferens has several ammonium transporters, and this ammonium transporter is different than the one previously shown to be upregulated under $\mathrm{N}$-deficient conditions in A. anophagefferens (Berg et al., 2008). Clearly, A. anophagefferens upregulates a variety of ammonium transporters in response to $\mathrm{N}$ deficiency, which is consistent with the preference for reduced $\mathrm{N}$ observed in low nitrate field populations (Gobler et al., 2005).

Past studies have shown that $A$. anophagefferens can hydrolyse proteins, and grow well on DON, such as aminosugars, urea and amino acids, as a sole $\mathrm{N}$ source (Berg et al., 2002; 2003; Mulholland et al., 2002). It has also been reported to grow on small amides as a sole $\mathrm{N}$ source, including acetamide and, to a lesser extent, formamide (Berg et al., 2008). This is consistent with other studies that identified that dinoflagellates, coccolithophores and diatoms grow on acetamide, and that coccolithophores grow well on formamide (Palenik and Henson, 1997). Tag 3830, which mapped to an acetamidase/ formamidase, is upregulated in the $-\mathrm{N}$ library, which suggests that $A$. anophagefferens can break down these small amides, and that this process is regulated by $\mathrm{N}$ deficiency. Increased activities of acetamidase and formamidase were detected in $\mathrm{N}$-deficient $E$. huxleyi (Palenik and Henson, 1997), which is consistent with the transcript regulation observed herein. The sources and concentrations of amides in marine systems are poorly understood, but they may serve as $\mathrm{N}$ sources for field populations, especially those experiencing $\mathrm{N}$ deficiency. $A$. anophagefferens also upregulates a putative xanthine/uracil/ vitamin $\mathrm{C}$ permease. In a tiling array experiment with T. pseudonana, a putative xanthine/uracil/vitamin $\mathrm{C}$ permease was also shown to be upregulated under $\mathrm{N}$-deficient conditions (Mock et al., 2008). As a result of the broad annotation it is difficult to determine the function of this gene in $A$. anophagefferens. Uric acid permeases have been shown to promote the uptake of uric acid into cells of Bacillus subtilis in N-deficient conditions (Schultz et al., 2001). This gene may be serving a similar role in $A$. anophagefferens. Two tags mapping to putative peptidases were identified in the Long-SAGE libraries, with higher expression in the $-\mathrm{N}$ library relative to the $-\mathrm{P}$ library. Given their regulation pattern, these peptidases may serve to scavenge $\mathrm{N}$ from peptides, although peptidases serve many roles in a cell besides $\mathrm{N}$ scavenging from proteins. Further, there is a tag upregulated in the $-\mathrm{N}$ library that mapped to an $\mathrm{N}$-acetylglucosamine transferase. O-GlcNAcylation (mediated by $\mathrm{N}$ acetylglucosamine transferase) has been shown to affect protein activity, stability and localization and this, 
taken together with the upregulation of the peptidases, suggests an increased protein metabolism and protein processing during $\mathrm{N}$ deficiency. Whether this is related to recycling of $\mathrm{N}$ inside the cell, or the acquisition of $\mathrm{N}$ from proteins or peptides from seawater, deserves further study.

It should be noted that both control and $-\mathrm{N}$ treatments consisted of nitrate as the primary $\mathrm{N}$ source. In the diatom C. fusiformis, ammonia transporters are transcriptionally regulated with highest mRNA copies in $\mathrm{N}$-starved cells, followed by cells grown on $\mathrm{NO}_{3}{ }^{-}$only, and lowest mRNA copies in ammonium-grown cells (Hildebrand, 2005), suggesting negative regulation by ammonium. In A. anophagefferens, it has been shown that certain genes involved in $\mathrm{N}$-metabolism can be transcriptionally regulated by $\mathrm{N}$ source (Berg et al., 2008). It may be possible that a stronger global transcriptional response would be seen if $A$. anophagefferens had been grown on ammonia, rather than nitrate, as the primary $\mathrm{N}$ source in the control library. Regardless, these data support the observation that $A$. anophagefferens can utilize a wide variety of $\mathrm{N}$ sources and switches to these $\mathrm{N}$ sources (including reduced and organic forms) at the onset of $\mathrm{N}$ deficiency. As discussed with $\mathrm{P}$-regulated genes, additional culture studies could be used to identify if these responses are related to acclimation to $\mathrm{N}$ deficiency.

\section{General stress response}

A number of tags were upregulated in response to both $P$ and $\mathrm{N}$ deficiency, possibly as part of a general stress response. Interestingly, three tags (1814, 2687 and 922) mapped to proteins involved in light harvesting. Regulation of these gene families in other algae is variable. In the coccolithophore E. huxleyi, a Long-SAGE study showed downregulation of a fucoxanthin chlorophyll a/c binding (Fcp) protein under $\mathrm{N}$ starvation (Dyhrman et al., 2006), and in diatoms genes encoding Fcp and LHC-like proteins were significantly upregulated in Fe-limited conditions (Allen et al., 2008). In the case of $A$. anophagefferens, it may be that there is broad downregulation of many genes under stress, and that this downregulation is not as strong, or not as rapid for light harvesting related machinery. In fact, a number of tags were downregulated in both $-\mathrm{N}$ and $-\mathrm{P}$ libraries, and have highest copy numbers in the control library. Owing to the fact that it requires resources to actively express genes, this downregulation may be driven by a global stress response to conserve resources. A more detailed time-course study that quantifies RNA levels, and includes an Fe-deficient condition would examine the consistency of the regulation on genes encoding proteins related to light harvesting.

Tag 2 mapped to a ubiquitin gene and is expressed at a high copy number in the control library, but is downregulated in both $-\mathrm{N}$ and $-\mathrm{P}$ libraries. Ubiquitin is a protein involved in post-translational modification of proteins, usually targeting them for proteosomal destruction (Hershko and Heller, 1985). A high expression of this protein in nutrient replete, exponentially growing, $A$. anophagefferens cultures suggests changes in protein turnover relative to the other treatments, and that this pathway is responsive to general stress. In the group of tags elevated in the control library, one tag (4684) mapped to a nitrite reductase while tag 4697 mapped to a nitrate transporter. Another targeted gene expression study of this species showed upregulation of this same nitrate transporter under acute $\mathrm{N}$ deficiency (25 days in low $\mathrm{N}$ medium) compared with $A$. anophagefferens grown on acetamide as the sole $\mathrm{N}$ source (Berg et al., 2008). Berg and colleagues (2008) also demonstrated that the nitrate transporter gene was induced by nitrate. In the Long-SAGE study presented here, nitrate was used as the $\mathrm{N}$ source for all treatments, and nitrate replete expression patterns (control) were compared with cells grown roughly 8 days in low nitrate medium $(-N)$, which may explain some of the differences. Nevertheless, these data indicate that the nitrate transporter expression is sensitive to both total $\mathrm{N}$ concentration as well as nitrate concentration. Therefore, the regulation patterns observed in the Long-SAGE libraries may be controlled by a combination of growth on nitrate and total $\mathrm{N}$ availability.

This is the first transcriptional data to examine general stress responses in a Pelagophyte. These transcriptional data suggest that under stress conditions, such as $\mathrm{N}$ and $\mathrm{P}$ deficiency, $A$. anophagefferens may broadly downregulate many genes involved in general metabolism, while maintaining light harvesting capability. However, the lack of tags mapping to genes encoding heat shock proteins, chaperons and other markers of a cellular stress response, indicates that higher resolution sampling is required to detect a comprehensive stress response transcriptome.

\section{Non-differentially expressed genes}

In addition to transcripts discussed above, a number of tags mapped to genes with known roles in $\mathrm{N}$ and $\mathrm{P}$ metabolism. These remaining tags of interest are all at too low a copy number to resolve differential expression patterns. This includes tags that mapped to transporters for compounds known to be utilized as an $\mathrm{N}$ source by $A$. anophagefferens, including nitrate, ammonium, urea and amino acids (Fig. 5). There was also a tag that mapped to a formate/nitrite transporter, although it is unclear whether $A$. anophagefferens can utilize nitrite as a sole $\mathrm{N}$ source (Fig. 5). Finally, tags that mapped to the enzymes nitrite reductase, nitrate reductase, glutamine 
synthetase, urease and cyanase were found (Fig. 5). The expression data of these $\mathrm{N}$-related genes are consistent with data from $A$. anophagefferens EST libraries (Berg et al., 2008), and given that the Long-SAGE data comprise the most highly expressed genes, it also indicates that these genes are highly expressed in the cells. The cyanase is included as related to $\mathrm{N}$ metabolism because cyanase hydrolyses cyanate into ammonium and carbon dioxide, and has been shown to play an important role in scavenging $\mathrm{N}$ from cyanate in cyanobacteria (Kamennaya et al., 2008). The Long-SAGE results suggest that cyanase is expressed, but not regulated by $\mathrm{N}$ in $A$. anophagefferens; however, a targeted study would address this with more sensitivity than afforded by the current analysis.

In this set of $\mathrm{N}$ metabolism transcripts, tag 113 mapped to an EST with sequence homology to a high affinity urea transporter from the picoeukaryote Ostreococcus tauri (Derelle et al., 2006). This tag is expressed under nutrient replete and $-\mathrm{N}$ conditions, but downregulated under $P$ deficiency. The same urea transporter has been shown to be upregulated under acute $\mathrm{N}$ deficiency (Berg et al., 2008). This difference may be explained by the fact that Long-SAGE is not as sensitive as quantitative RT-PCR at the depth of sequencing in this study, or that cells in the Berg and colleagues' 2008 study were grown on acetamide, not nitrate. Regardless, both evidence from quantitative RT-PCR and Long-SAGE support the hypothesis that $A$. anophagefferens is able to scavenge urea from the environment. Consistent with this finding, several culture studies have demonstrated that $A$. anophagefferens can grow equally well on both urea and nitrate as an N source (Maclntyre et al., 2004; Pustizzi et al., 2004) and that urea enrichments can stimulate A. anophagefferens blooms in situ (Kana et al., 2004).

\section{Conclusions}

The goal of this study was to examine the transcriptome of $A$. anophagefferens under varying environmental conditions (such as $-\mathrm{N}$ or $-\mathrm{P}$ ), to elucidate the broad-scale responses of this organism to nutrient deficiency, and to gain a better understanding of the metabolic pathways involved in nutrient acquisition. Many of the tags that are most highly upregulated in the $-\mathrm{N}$ and $-\mathrm{P}$ library mapped to predicted or hypothetical genes, or areas of the genome where no gene model exists (Tables S1-S3). This underscores how little is known about the genes and pathways of nutrient metabolism in this Pelagophyte and the importance of further studies focused on characterizing these genes and their function. However, this study supports the hypothesis that $A$. anophagefferens can metabolize reduced or organic forms of $N$ and $P$ when inorganic nutrients are not available. $A$. anophagefferens expresses and regulates a suite of genes related to $N$ acquisition/metabolism, including the genes necessary for growth on a variety of $\mathrm{N}$ compounds (Fig. 5). This is consistent with observations from both culture and field data (Lomas et al., 1996; Berg et al., 1997; 2002; 2003; Mulholland et al., 2002; Kana et al., 2004; MacIntyre et al., 2004; Pustizzi et al., 2004). A. anophagefferens also expresses genes involved in both DIP and DOP uptake and metabolism, and these appear to be highly upregulated under $P$ deficiency (Fig. 5). Very little is known about how $\mathrm{P}$ influences $A$. anophagefferens blooms, but the results indicate that DOP could be important to the $P$ nutrition of this species adding further evidence for the importance of organic nutrients in fuelling the growth of this harmful species in sensitive coastal regions.

These data have identified gene targets with expression patterns that are indicative of a switch to growth on organic nutrients. As such, monitoring the quantitative expression of these gene targets may serve as a tool for examining $N$ and $P$ deficiency in natural populations over the course of a bloom cycle, ultimately providing a much needed link between nutrient supply and $A$. anophagefferens bloom dynamics.

\section{Experimental procedures}

\section{Culture conditions}

Aureococcus anophagefferens CCMP 1984 was obtained from the Provasoli-Guillard Center for the Culture of Marine Phytoplankton (CCMP). The cultures were grown in batch to examine the instantaneous transcriptome response of $A$. anophagefferens to nutrient deficiency at $18^{\circ} \mathrm{C}$ on a $14: 10 \mathrm{~h}$ light : dark cycle $\left(140 \mu \mathrm{mol}\right.$ quanta $\left.\mathrm{m}^{-2} \mathrm{~s}^{-1}\right)$. Nitrogen- and phosphate-replete $\left(883 \mu \mathrm{M} \mathrm{NO}_{3}{ }^{-}\right.$and $\left.36.3 \mu \mathrm{M} \mathrm{PO}_{4}{ }^{3-}\right)$ cells, $-\mathrm{N}\left(40 \mu \mathrm{M} \mathrm{NO}_{3}{ }^{-}\right)$cells and $-\mathrm{P}\left(1 \mu \mathrm{M} \mathrm{PO}_{4}{ }^{3-}\right)$ cells were grown in autoclaved L1 media with no Si (Guillard and Hargraves, 1993), prepared using $0.2 \mu \mathrm{m}$ filtered Vineyard Sound seawater. Vitamins (thiamine, biotin and $B_{12}$ ) were sterile filtered and added to the media after autoclaving. The growth of the cultures was monitored daily by cell counts on a haemacytometer. Replete cells were harvested during mid log phase of growth, while $-\mathrm{N}$ and $-\mathrm{P}$ cells were harvested at the onset of stationary phase when $\mathrm{N}$ or $\mathrm{P}$ was depleted (Fig. 1). With additions of $\mathrm{N}\left(883 \mu \mathrm{M} \mathrm{NO}_{3}{ }^{-}\right)$or $\mathrm{P}\left(36.3 \mu \mathrm{M} \mathrm{PO}{ }_{4}{ }^{3}\right)$ to the nutrient-depleted treatments, the cells resumed exponential growth (data not shown). To test whether $A$. anophagefferens can grow on AMP, an additional culture experiment was performed. $A$. anophagefferens was grown in L1 media with no $\mathrm{Si}$ as described above with the following changes: In the $\mathrm{PO}_{4}{ }^{3-}$ treatment, cells were grown in media containing $\left(36.3 \mu \mathrm{M} \mathrm{PO}_{4}{ }^{3-}\right)$. For the AMP treatment, cells were grown in media containing no added $\mathrm{PO}_{4}{ }^{3}$, but instead contained AMP at a concentration of $36.3 \mu \mathrm{M}$. Media with no added $\mathrm{P}$ were used as a control and growth was monitored with a Turner Designs fluorometer. 


\section{Total RNA extraction}

Approximately $2 \times 10^{7}$ cells were harvested $(8000 \mathrm{~g}$ for $10 \mathrm{~min}$ ) from each treatment and immediately stored in liquid nitrogen until extraction. Total RNA was extracted using TRI reagent (Sigma) according to the manufacturer's instructions RNA concentrations were quantified with a UV spectrophotometer. Integrity of the total RNA was assessed by $1 \%$ (wt/vol) agarose gel electrophoresis.

\section{Long-SAGE library construction}

Long-SAGE libraries were constructed using approximately $30 \mu \mathrm{g}$ RNA isolated from extractions of replete (control), $-P$, and $-\mathrm{N} A$. anophagefferens cells following the I-SAGE Long kit protocol (Invitrogen). Recombinant pZEro1 clones produced by Long-SAGE were purified using GeneMachines RevPrep Orbit (Genomic Solutions) and were sequenced on an ABI 3730xI DNA sequencer (Applied Biosystems). The sequences collected were analysed with software created at the Marine Biological Laboratory specifically for SAGE analysis and used in the context of previous work (Dyhrman et al., 2006). The SAGE software extracts ditag sequences from the $A B I 3730 \times 1$ results according to the Long-SAGE sequence grammar, parses out individual Long-SAGE tags, excludes tags with sequence ambiguities, and reduces all Long-SAGE tags to a look-up table of unique Long-SAGE tag sequences and their observed frequencies among all of the $A$. anophagefferens Long-SAGE libraries. All Long-SAGE tags were mapped to sequence data (see below) for annotation, but those tags found only once (singletons) were excluded from differential expression analysis.

Tags were annotated by mapping to $A$. anophagefferens ESTs on GenBank (http://www.ncbi.nlm.nih.gov), or the unpublished $A$. anophagefferens genome data sequenced by the DOE Joint Genome Institute (JGI) and located on their portal page (http://www.jgi.doe.gov/Aureococcus). Because Long-SAGE tags are short (21 bp), an exact match was required. Tags mapping to the genome were annotated based on their overlap or proximity to gene models. ESTs specific to $A$. anophagefferens were used to help annotate tags in which a gene model could not be assigned, or for tags that did not map to the genome sequence, but did map to ESTs. These ESTs were assembled into clusters and blasted against GenBank using blastX to assign a putative function using an expect value cut-off of 1e-5.

Long-SAGE tags were scored for differential expression among the three libraries by using the $R$ statistic (Stekel et al., 2000), a log likelihood ratio statistic that scores tags by their deviation from the null hypothesis of equal frequencies given the tag sampling depth for each Long-SAGE library. Higher scores represent a greater deviation from the null hypothesis, while scores close to zero represent near constitutive expression. To reduce the effects of sampling error in highlighting differential expression, only tags with an $R$-value of 2 or greater are presented. Additionally, if more than one tag mapped to the same sequence, only the most $3^{\prime}$ tag was included here. The tag data discussed in this publication have been deposited in NCBl's Gene Expression Omnibus (Edgar et al., 2002) and are accessible through GEO Series accession number GSE21465 (http://www.ncbi.nlm.nih.gov/geo/ query/acc.cgi?acc=GSE21465).

\section{Acknowledgements}

This paper is a result of research funded by the National Oceanic and Atmospheric Administration Center for Sponsored Coastal Ocean Research under award NA09NOS4780206 to WHOI. ECOHAB publication number 614. Further support came from funds from the Woods Hole Oceanographic Institution, the Woods Hole Center for Oceans and Human Health and the Woods Hole Coastal Ocean Institute, a STAR Research Assistance Agreement No. R-83041501-0 awarded by the U.S. Environmental Protection Agency, as well as an EPA STAR fellowship (STAR Fellowship assistance agreement number FP916901). We would like to thank the JGI and the Aureococcus genome consortium. The Aurecoccus genome sequencing and analysis were performed under the auspices of the US Department of Energy's Office of Science, Biological and Environmental Research Program, and by the University of California, Lawrence Berkeley National Laboratory under contract No. DE-AC02-05CH11231, Lawrence Livermore National Laboratory under Contract No. DE-AC52-07NA27344, and Los Alamos National Laboratory under contract No. DE-AC0206NA25396. We would also like to thank the Marine Biological Laboratory's Josephine Bay Paul Center for sequencing and informatics assistance, particularly Shanda Birkeland and Andrew McArthur. Finally, we thank Alan Kuo, Astrid Terry, and Igor Grigoriev from the JGI for their efforts on the Aureococcus anophagefferens genome annotation as well as informatics supporting this study.

\section{References}

Allen, A.E., LaRoche, J., Maheswari, U., Lommer, M., Schauer, N., Lopez, P.J., et al. (2008) Whole-cell response of the pennate diatom Phaeodactylum tricornutum to iron starvation. Proc Natl Acad Sci USA 105: 10438-10443.

Ammerman, J.W., and Azam, F. (1985) Bacterial $5^{\prime}$-nucleotidase in aquatic ecosystems - a novel mechanism of phosphorus regeneration. Science 227: 13381340.

Anderson, D.M., Burkholder, J.M., Cochlan, W.P., Glibert, P.M., Gobler, C.J., Heil, C.A., et al. (2008) Harmful algal blooms and eutrophication: examining linkages from selected coastal regions of the United States. Harmful Algae 8: 39-53.

Berg, G.M., Glibert, P.M., Lomas, M.W., and Burford, M.A. (1997) Organic nitrogen uptake and growth by the chrysophyte Aureococcus anophagefferens during a brown tide event. Mar Biol 129: 377-387.

Berg, G.M., Repeta, D.J., and LaRoche, J. (2002) Dissolved organic nitrogen hydrolysis rates in axenic cultures of Aureococcus anophagefferens (Pelagophyceae): comparison with heterotrophic bacteria. Appl Environ Microbiol 68: 401-404.

Berg, G.M., Repeta, D.J., and LaRoche, J. (2003) The role of the picoeukaryote Aureococcus anophagefferens in cycling of marine high-molecular weight dissolved organic nitrogen. Limnol Oceanogr 48: 1825-1830.

Berg, G.M., Shrager, J., Glockner, G., Arrigo, K.R., and Grossman, A.R. (2008) Understanding nitrogen limitation in Aureococcus anophagefferens (Pelagophyceae) 
through cDNA and qRT-PCR analysis. J Phycol 44: 12351249.

Chung, C.C., Hwang, S.P.L., and Chang, J. (2003) Identification of a high affinity phosphate transporter gene in a prasinophyte alga, Tetraselmis chui, and its expression under nutrient limitation. Appl Environ Microbiol 69: 754759.

Coyne, K.J., Burkholder, J.M., Feldman, R.A., Hutchins, D.A., and Cary, S.C. (2004) Modified serial analysis of gene expression method for construction of gene expression profiles of microbial eukaryotic species. Appl Environ Microbiol 70: 5298-5304.

Dennison, W.C., Marshall, G.J., and Wigand, C. (1989) Effects of 'brown tide' shading on eelgrass (Zostera marina) distributions. In Novel Phytoplankton Blooms: Causes and Impacts of Recurrent Brown Tides and Other Unusual Blooms, Volume 35. Cosper, E.M., Bricelj, V.M., and Carpenter, E.J. (eds). New York, NY, USA: Springer, pp. 675-692.

Derelle, E., Ferraz, C., Rombauts, S., Rouze, P., Worden, A.Z., Robbens, S., et al. (2006) Genome analysis of the smallest free-living eukaryote, Ostreococcus tauri unveils many unique features. Proc Natl Acad Sci USA: 103: 11647-11652.

Dyhrman, S.T. (2008) Molecular approaches to diagnosing nutritional physiology in harmful algae: implications for studying the effects of eutrophication. Harmful Algae 8: 167-174.

Dyhrman, S.T., and Palenik, B. (1999) Phosphate stress in cultures and field populations of the dinoflagellate Prorocentrum minimum detected by a single-cell alkaline phosphatase assay. Appl Environ Microbiol 65: 32053212.

Dyhrman, S.T., and Palenik, B. (2003) Characterization of ectoenzyme activity and phosphate-regulated proteins in the coccolithophorid Emiliania huxleyi. J Plankton Res 205: 230-231.

Dyhrman, S.T., Haley, S.T., Birkeland, S.R., Wurch, L.L., Cipriano, M.J., and McArthur, A.G. (2006) Long Serial Analysis of Gene Expression for gene discovery and transcriptome profiling in the widespread marine coccolithophore Emiliania huxleyi. Appl Environ Microbiol 72: 252-260.

Dzurica, S., Lee, C., Cosper, E.M., and Carpenter, E.J. (1989) Role of environmental variables, specifically organic compounds and nutrients, in the growth of the chrysophyte Aureococcus anophagefferens. In Novel Phytoplankton Blooms: Causes and Impacts of Recurrent Brown Tides and Other Unusual Blooms, Volume 35. Cosper, E.M., Bricelj, V.M., and Carpenter, E.J. (eds). New York, NY, USA: Springer, pp. 229-252.

Edgar, R., Domrachev, M., and Lash, A.E. (2002) Gene Expression Omnibus: NCBI gene expression and hybridization array data repository. Nucleic Acids Res 30: 207210.

Erdner, D.L., and Anderson, D.M. (2006) Global transcriptional profiling in the toxic dinoflagellate Alexandrium fundyense using massively parallel signature sequencing. BMC Genomics 7: 88.

Flynn, K.J., Öpik, H., and Syrett, P.J. (1986) Localization of the alkaline phosphatase and $5^{\prime}$-nucleotidase activities of the diatom Phaeodactylum tricornutum. $J$ Gen Microbiol 132: 289-298.

Gobler, C.J., and Sañudo-Wilhelmy, S.A. (2001) Effects of organic carbon, organic nitrogen, inorganic nutrients, and iron additions on the growth of phytoplankton and bacteria during a brown tide bloom. Mar Ecol Prog Ser209: 19-34.

Gobler, C.J., Renaghan, M.J., and Buck, N.J. (2002) Impacts of nutrients and grazing mortality on the abundance of Aureococcus anophagefferens during a New York brown tide bloom. Limnol Oceanogr 47: 129-141.

Gobler, C.J., Boneillo, G.E., Debenham, C., and Caron, D.A. (2004) Nutrient limitation, organic matter cycling, and plankton dynamics during an Aureococcus anophagefferens bloom in Great South Bay, N.Y. Aquat Microb Ecol 35: 31-43.

Gobler, C.J., Lonsdale, D.J., and Boyer, G.L. (2005) A review of the causes, effects, and potential management of harmful brown tide blooms caused by Aureococcus anophagefferens (Hargraves et Sieburth). Estuaries 28: 726749.

Greenfield, D.I., and Lonsdale, D.J. (2002) Mortality and growth of juvenile hard clam Mercenaria mercenaria during brown tide. Mar Biol 141: 1045-1050.

Greenfield, D.I., Lonsdale, D.J., Cerrato, R.M., and Lopez, G.R. (2004) Effects of background concentrations of Aureococcus anophagefferens (brown tide) on growth and feeding in the bivalve Mercenaria mercenaria. Mar Ecol Prog Ser 274: 171-181.

Grossman, A. (2000) Acclimation of Chlamydomonas reinhardtii to its nutrient environment. Protist 151: 201-224.

Guillard, R.R.L., and Hargraves, P.E. (1993) Stichochrysis immobilis is a diatom, not a chrysophyte. Phycologia 32: 234-236.

Hershko, A., and Heller, H. (1985) Occurrence of a polyubiquitin structure in ubiquitin-protein conjugates. Biochem Biophys Res Commun 128: 1079-1086.

Hildebrand, M. (2005) Cloning and functional characterization of ammonium transporters from the marine diatom Cylindrotheca fusiformis. J Phycol 41: 105-113.

Irizarry, R.A., Warren, D., Spencer, F., Kim, I.F., Biswal, S., Frank, B.C., et al. (2005) Multiple-laboratory comparison of microarray platforms. Nat Methods 2: 477-477.

Kamennaya, N.A., Chernihovsky, M., and Post, A.F. (2008) The cyanate utilization capacity of marine unicellular Cyanobacteria. Limnol Oceanogr 53: 2485-2494.

Kana, T.M., Lomas, M.W., Maclntyre, H.L., Cornwell, J.C., and Gobler, C.J. (2004) Stimulation of the brwon tide organism, Aureococcus anophagefferens, by selective nutrient additions to in situ mesocosms. Harmful Algae 3: 377-388.

Keller, A.A., and Rice, R.L. (1989) Effects of nutrient enrichment on natural populations of the brown tide phytoplankton Aureococcus anophagefferens (Chrysophyceae). J Phycol 25: 636-646.

Landry, D.M., Gaasterland, T., and Palenik, B.P. (2006) Molecular characterization of a phosphate-regulated cellsurface protein from the coccolithophorid, Emiliania huxleyi (Prymnesiophyceae). J Phycol 42: 814-821.

LaRoche, J., Nuzzi, R., Waters, R., Wyman, K., Falkowski, P.G., and Wallace, D.W.R. (1997) Brown tide blooms in 
Long Island's coastal waters linked to variability in groundwater flow. Glob Change Biol 3: 397-410.

Lomas, M.W., Glibert, P.M., and Berg, G.M. (1996) Characterization of nitrogen uptake by natural populations of Aureococcus anophagefferens (Chrysophyceae) as a function of incubation duration, substrate concentration, light, and temperature. J Phycol 32: 907-916.

MacIntyre, H.L., Lomas, M.W., Cornwell, J.C., Suggett, D., Gobler, C.J., Koch, E., and Kana, T.M. (2004) Mediation of benthic-pelagic coupling by microphytobenthos: an energy and nutrient based model for initiation of blooms of Aureococcus anophagefferens. Harmful Algae 3: 403-437.

Mock, T., Samanta, M.P., Iverson, V., Berthiaume, C., Robison, M., Holtermann, K., et al. (2008) Whole genome expression profiling of the marine diatom Thalassiosira pseudonana identifies genes involved in silicon bioprocesses. Proc Natl Acad Sci USA 105: 1579-1584.

Morozova, O., Hirst, M., and Marra, M.A. (2009) Applications of new sequencing technologies for transcriptome analysis. Annu Rev Genomics Hum Genet 10: 135-151.

Mulholland, M.R., Gobler, C.J., and Lee, C. (2002) Peptide hydrolysis, amino acid oxidation and $\mathrm{N}$ uptake in communities seasonally dominated by Aureococcus anophagefferens. Limnol Oceanogr 47: 1094-1108.

Mulholland, M.R., Boneillo, G., and Minor, E.C. (2004) A comparison of $\mathrm{N}$ and $\mathrm{C}$ uptake during brown tide (Aureococcus anophagefferens) blooms from two coastal bays on the east coast of the USA. Harmful Algae 3: 361-376.

Palenik, B., and Henson, S.E. (1997) The use of amides and other nitrogen sources by the phytoplankton Emiliania huxleyi. Limnol Oceanogr 42: 1544-1551.

Pustizzi, F., Maclntyre, H.L., Warner, M.E., and Hutchins, D.A. (2004) Interaction of nitrogen source and light intensity on the growth and photosynthesis of the brown tide alga Aureococcus anophagefferens. Harmful Algae 3: 343-360.

Saha, S., Sparks, A.B., Rago, C., and Akmaev, V. (2002) Using the transcriptome to annotate the genome. Nat Biotechnol 19: 508-512.

Schultz, A.C., Nygaard, P., and Saxild, H.H. (2001) Functional analysis of 14 genes that constitute the purine catabolic pathway in Bacillus subtilis and evidence for a novel regulon controlled by the PucR transcription activator. J Bacteriol 183: 3293-3302.

Stekel, D.J., Git, Y., and Falciani, F. (2000) The comparison of gene expression from multiple cDNA libraries. Genome Res 10: 2055-2061.

Sunda, W.G., Graneli, E., and Gobler, C.J. (2006) Positive feedback and the development and persistence of ecosystem disruptive algal blooms. $J$ Phycol 42: 963-974.

Velculescu, V.E., Zhang, L., Vogelstein, B., and Kinzler, K.W. (1995) Serial analysis of gene expression. Science 270: 484-487.

Wang, S.M. (2007) Understanding SAGE data. Trends Genet 23: $42-50$.

Xu, Y., Wahlund, T.M., Feng, L., Shaked, Y., and Morel, F.M.M. (2006) A novel alkaline phosphatase in the coccolithophore Emiliania huxleyi (Prymnesiophyceae) and its regulation by phosphorus. $J$ Phycol 42: 835-844.

\section{Supporting information}

Additional Supporting Information may be found in the online version of this article:

Table S1. Complete list of tags showing greater than twofold upregulation in the $-P$ library relative to both the control and $-N$ libraries $(R \geq 2)$.

Table S2. Complete list of tags showing greater than twofold upregulation in the $-\mathrm{N}$ library relative to both the control and $-P$ libraries $(R \geq 2)$.

Table S3. Complete list of tags showing greater than twofold upregulation in both the $-\mathrm{P}$ and $-\mathrm{N}$ libraries relative to the control library $(R \geq 2)$.

Table S4. Complete list of tags showing greater than twofold upregulation in the control library relative to both the $-P$ and $-N$ libraries $(R \geq 2)$.

Please note: Wiley-Blackwell are not responsible for the content or functionality of any supporting materials supplied by the authors. Any queries (other than missing material) should be directed to the corresponding author for the article. 
CHAPTER THREE

Proteome changes driven by phosphorus deficiency and recovery in the brown tideforming alga, Aureococcus anophagefferens

\author{
Louie L. Wurch \\ Erin M. Bertrand ${ }^{\mathrm{b}}$ \\ Mak A. Saito \\ Benjamin A.S. Van Mooy ${ }^{\mathrm{b}}$ \\ Sonya T. Dyhrman ${ }^{\text {a.c }}$
}

${ }^{a}$ Biology Department, Woods Hole Oceanographic Institution, Woods Hole, MA 02543 USA

${ }^{b}$ Department of Marine Chemistry \& Geochemistry, Woods Hole Oceanographic Institution, Woods Hole, MA 02543 USA

cCorresponding author: sdyhrman@whoi.edu

In prep: PLoS ONE 


\begin{abstract}
Shotgun mass spectrometry was used to detect proteins in Aureococcus anophagefferens and monitor their relative abundance across nutrient replete (control), phosphate-deficient (-P) and $-\mathrm{P}$ refed with phosphate (P-refed) conditions. Spectral counting techniques identified differentially abundant proteins and demonstrated that under phosphate deficiency, A. anophagefferens increases proteins involved in both inorganic and organic phosphorus (P) scavenging, including a phosphate transporter, 5'-nucleotidase, and alkaline phosphatase. Additionally, an increase in abundance of a sulfolipid biosynthesis protein was detected in $-\mathrm{P}$ and $\mathrm{P}$-refed conditions. Analysis of the polar membrane lipids showed that cellular concentrations of the sulfolipid sulphoquinovosyldiacylglycerol (SQDG) was nearly two-fold greater in the -P condition versus the control condition, while cellular phospholipids were approximately 8-fold less. Transcript and protein abundance generally appeared to be more tightly coupled for gene products involved in $\mathrm{P}$ metabolism compared to those involved in a range of other metabolic functions. Comparison of protein abundances between the $-\mathrm{P}$ and $\mathrm{P}$-refed conditions identified differences in the timing of protein degradation and turnover. This suggests that culture studies examining nutrient starvation responses will be valuable in interpreting protein abundance patterns for cellular nutritional status and history in metaproteomic datasets.
\end{abstract}

\title{
Introduction
}

Aureococcus anophagefferens is the phytoplankton species responsible for harmful brown tides that have caused extensive damage to a number of coastal 
ecosystems in the Eastern United States (Gobler et al. 2005). Brown tides have led to a collapse of the Long Island scallop industry and caused substantial losses to eelgrass habitats (Dennison et al. 1989, Greenfield and Lonsdale 2002, Greenfield et al. 2004). Furthermore, brown tides are becoming more frequent and widespread, as evidenced by brown tides now occurring in South Africa (Gobler et al. 2005). Due to its negative impacts and the regular and widespread occurrence of blooms, A. anophagefferens has become a broadly studied harmful algal bloom (HAB) species (see reviews Gobler et al. 2005, Sunda et al. 2006) and is the first HAB species to have its genome sequenced (Gobler et al. 2011).

Past studies have suggested that brown tides are driven by periods of low dissolved inorganic nitrogen (DIN) and low dissolved inorganic phosphorus (DIP) availability (LaRoche et al. 1997, Keller and Rice 1989, Gobler and Sañudo-Wilhelmy 2001, Gobler et al. 2002, Gobler et al. 2004, Kana et al. 2004). Although studies of phosphorus $(\mathrm{P})$ effects on bloom dynamics are more limited than those of nitrogen $(\mathrm{N})$, field observations from brown tides have shown significant reductions in dissolved organic phosphorus (DOP) concentrations during peak A. anophagefferens cell densities (Gobler et al. 2004). Analysis of the genome suggests that A. anophagefferens has the capacity to utilize P from a variety of organic sources, including esters, diesters, and nucleotides (Gobler et al. 2011). In culture, A. anophagefferens can utilize nucleotide DOP such as adenosine monophosphate (AMP) as a sole $\mathrm{P}$ source, which is consistent with genome observations (Gobler et al. 2011, Wurch et al. 2011). When DIP becomes deficient, A. anophagefferens exhibits a broad transcriptional response, up-regulating a 
variety of these P-scavenging genes such as a phosphate transporter, 5'-nucleotidase, and alkaline phosphatase, where the latter two are important enzymes used by phytoplankton to access P from the DOP pool (Wurch et al. 2011). These data, combined with field observations, suggest that DOP could be important in controlling bloom persistence and decline.

Genome and transcriptome sequencing efforts have provided key insights into the metabolic potential of harmful phytoplankton species (Parker et al. 2008, Dyhrman 2008). Despite the value of these sequencing efforts, studies in humans have demonstrated that much of the transcribed genome is never translated (Birney et al. 2007), suggesting that transcriptome analyses may overestimate actual cellular processes and physiological responses to nutritional status. Mass spectrometry-based proteomics allow direct measurements of changes in an organism's protein pool, thus more accurately assessing the arsenal of chemical responses these organisms employ for growth under different physiological conditions. Proteomics is also a valuable compliment to nucleic acid sequencing approaches as a tool for examining whether physiological responses can be linked to upstream transcriptional patterns. Recently, mass spectrometry-based proteomic approaches have successfully been employed to analyze primary metabolic and biosynthetic pathways in the diatom Thalassiosira pseudonana (Nunn et al. 2007) as well as the diazotrophic unicellular marine cyanobacteria Crocosphaera watsonii (Saito et al. 2011). Similar proteomic techniques are currently being applied to in situ ocean communities and have allowed for the direct observation of expressed proteins from mixed microbial consortia (Sowell et al. 2009, 
Morris et al. 2010). These metaproteomic approaches revealed that transporters dominate the pool of identifiable proteins in low nutrient environments on ocean-wide scales (Sowell et al. 2009, Morris et al. 2010). However, without detailed information on protein regulation, it is difficult to link the abundance of particular proteins, like these transporters, to cellular physiology or a cell's geochemical environment.

Herein, shotgun mass spectrometry was used to identify protein abundances in $A$. anophagefferens in nutrient replete (control) and phosphate-deficient (-P) treatments. In order to examine the timing of these responses, proteins were also assayed in a phosphate-refed (P-refed) treatment, where replete levels of phosphate were added to -P cells over a 24-hour period. Protein abundances were compared between two treatments using spectral counting and compared to transcript expression patterns from a previous study (Wurch et al. 2011).

\section{Materials and Methods}

\section{Culture conditions}

An axenic culture of $A$. anophagefferens strain CCMP 1984 was obtained from the Provasoli-Guillard Center for the Culture of Marine Phytoplankton (CCMP). Culture treatments were grown in triplicate Fernbach flasks in $2 \mathrm{~L}$ of media per replicate at $18^{\circ} \mathrm{C}$ on a 14 hour: 10 hour light:dark cycle at $150 \mu \mathrm{mol}$ quanta $\mathrm{m}^{-2} \mathrm{~s}^{-1}$. Locally collected Vineyard Sound seawater was filtered $(0.2 \mu \mathrm{m})$ and used to make modified L1 media with no added silica (Guillard and Hargraves 1993). P concentrations were modified as follows: $36 \mu \mathrm{M}$ phosphate for the control treatment and $1 \mu \mathrm{M}$ phosphate for the P- 
deficient $(-\mathrm{P})$ treatment. Vitamins (thiamine, biotin, and $\mathrm{B}_{12}$ ) were sterile filtered and added after autoclaving. Each flask was then inoculated with $A$. anophagefferens stock culture to a starting concentration of $10^{5}$ cells $\mathrm{mL}^{-1}$. Growth was monitored daily by cell counts on a hemacytometer and relative fluorescence using a Turner Designs fluorometer. Cells were harvested by centrifugation to form pellets and immediately stored in liquid nitrogen. Control treatment cells were harvested on day 6 during exponential phase of growth and $-\mathrm{P}$ treatment cells were harvested on day 8 , at onset of stationary phase (Figure S1). Phosphate was then added back to the remaining $-\mathrm{P}$ cells to a final concentration of $36 \mu \mathrm{M}$. These P-refed cells were harvested 24 hours later.

\section{Protein extraction and digestion}

Cell pellets (single biological replicate from each treatment) were resuspended in $700 \mu \mathrm{L}$ B-PER reagent (Thermo Scientific, Rockford, IL) supplemented with $5 \mathrm{mM}$ EDTA and $1 \mathrm{mM}$ phenylmethanesulfonylfluoride (a serine protease inhibitor). Samples were incubated at room temperature for 40 minutes with occasional gentle vortexing and then incubated on ice for 10 minutes. The cells were then sonicated with a microtip (Branson digital sonifier) on ice for 1 minute at constant duty cycle. Samples were centrifuged for 40 minutes at $14,100 \mathrm{RCF}$ and $4{ }^{\circ} \mathrm{C}$, and protein was precipitated out of the supernatants overnight in $50 \%$ acetone $50 \%$ methanol $0.5 \mathrm{mM} \mathrm{HCl}$ at $-20{ }^{\circ} \mathrm{C}$. Precipitated protein was collected by centrifugation at $14,100 \mathrm{RCF}$ for 30 minutes at $4{ }^{\circ} \mathrm{C}$ and dried by speed vacuum at room temperature. Protein was resuspended in $100 \mathrm{uL}$ of the extraction buffer. Aliquots were taken for protein determination by DC assay using 
bovine serum albumin as a protein standard (BioRad Inc., Hercules CA). Proteins were stored at $-80{ }^{\circ} \mathrm{C}$ until digestion.

Protein samples were digested following the tube gel digestion procedure ( $\mathrm{Lu}$ and Zhu 2005) with minor modifications. Briefly, samples were immobilized in $15 \%$ acrylamide in pH 7.5 Tris buffer, fixed with $10 \%$ acetic acid and 50\% ethanol, washed successively with $10 \%$ acetic acid and $50 \%$ methanol, then acetonitrile and $25 \mathrm{mM}$ ammonium bicarbonate to remove detergents and protease inhibitors and then cut into 1 $\mathrm{mm}^{3}$ pieces. Samples were reduced with $10 \mathrm{mM}$ dithiothreitol (DTT) at $56^{\circ} \mathrm{C}$ for 1 hour, alkyated with $30 \mathrm{mM}$ iodoacetamide for 1 hour, and then washed in $25 \mathrm{mM}$ ammonium bicarbonate and digested with trypsin in $25 \mathrm{mM}$ ammonium bicarbonate for 16 hours at $37{ }^{\circ} \mathrm{C}$ (1:20 ratio trypsin to total protein, Promega Gold Mass Spectrometry Grade, Promega Inc., Madison WI). The peptides were extracted by three successive additions of $50 \%$ acetonitrile (Fisher Optima) with 5\% formic acid (Michrom Ultra Pure). The extracted peptides were combined and concentrated by speed vacuum for about three hours to less than $20 \mu \mathrm{L}$, diluted with $2 \%$ acetonitrile and $0.1 \%$ formic acid in water (Fisher Optima) and stored at $-80^{\circ} \mathrm{C}$.

\section{Shotgun mass spectrometry}

The protein digestions were analyzed ( $4 \mathrm{ug}$ total protein per analysis) using a peptide Cap Trap in-line with a reversed phase Magic C18 AQ column $(0.2 \times 150 \mathrm{~mm}, 3$ $\mu \mathrm{m}$ particle size, $200 \AA$ pore size, Michrom Bioresources Inc. Auburn CA) on a Paradigm MS4 HPLC system (Michrom Bioresources Inc.) at a flow rate of $2 \mu 1$ minute ${ }^{-1}$, similar to 
previously described methods [24]. A LTQ linear ion trap mass spectrometer (Thermo Scientific Inc. San Jose CA) was used with an ADVANCE nanocapillary captive electrospray source (Michrom Bioresources Inc.). The chromatography consisted of a hyperbolic gradient from $5 \%$ buffer A to $95 \%$ buffer B for 300 minutes, where A was $0.1 \%$ formic acid (Michrom Ultra Pure) in water (Fisher Optima) and B was $0.1 \%$ formic acid in acetonitrile (Fisher Optima). The mass spectrometer was set to perform MS/MS on the top 7 most abundant ions using data-dependent settings with a dynamic exclusion window of 30 seconds. Ions were monitored over the range of $400-2000 \mathrm{~m} / \mathrm{z}$. Technical triplicate measurements were conducted for each biological sample.

Mass spectrometry data processing and proteome profiling

The mass spectra collected in this study were searched using SEQUEST (Bioworks version 3.3, Thermo Inc., San Jose CA). An amino acid database for $A$. anophagefferens was constructed by combining all "project data" from the $A$. anophagefferens genome sequencing (11520 sequences from NCBI: http://www.ncbi.nlm.nih.gov/genomeprj/13500) and adding plastid proteins (105 sequences from NCBI: http://www.ncbi.nlm.nih.gov/genomeprj/36625), along with common contaminants as well as a reversed 'decoy' version of these databases for false discovery rate analysis (data downloaded on March 8th, 2011). Searches were conducted with a static modification for cysteine of +57 for alkylation by iodoacetamide and allowing for variable modifications expected if methionine was oxidized $(+16)$, if cysteine or methionine were present as seleno-residues $(+47)$ or if selenocysteine was 
modified to dehydroalanine (-91) (Ma et al. 2003). Database search results were further processed using the PeptideProphet statistical model (Keller et al. 2002) within Scaffold 3.0 (Proteome Software Inc., Portland OR). Relative protein abundance was determined using spectral counting in Scaffold 3.0. Spectral counts are normalized across samples in each experiment, including technical replicates, to allow comparison of relative protein abundance and result in a quantitative value abundance score, as previously described (Saito et al. 2011). Proteins discussed as 'differentially abundant' were determined by the Fisher exact test as previously described (Zhang et al. 2006) with $p$-values $<0.05$. False discovery identification rate was estimated using a reversed decoy database as previously described (Kall et al. 2008).

The proteins that met the criteria for being differentially abundant were compared by a hierarchical cluster analysis using Cluster 3.0 (Eisen et al. 1998). Average abundance scores for each sample were $\log$ transformed, centered about the mean and normalized by multiplying all values by a scale factor $\mathrm{S}$ so that the sum of the squares of the values for each protein is 1.0. The treatments were not centered or normalized. The data were then clustered by both protein and treatment using a centered correlation as metric and complete linkage as clustering method. The data were displayed using Java Tree View (Saldanha 2004).

\section{Proteome comparison to transcriptome}

A previous study (Wurch et al. 2011) generated transcriptome expression data under conditions identical to those examined in this study, excluding the P-refed cells, 
using Long Serial Analysis of Gene Expression (Long-SAGE). Tag data from LongSAGE were compared to the protein data obtained from this study. Only the $-\mathrm{P}$ and control treatments, and only genes with products identified in this study as well as the Long-SAGE study with at least two tags mapping to a given protein ID, were included in this analysis. Abundance scores from the proteome and tag counts from the transcriptome were compared using fold change in the $-\mathrm{P}$ treatment relative to the control. If the fold change resulted in a fraction due to a higher abundance in the control versus the $-\mathrm{P}$, then the negative inverse was taken (e.g. a fold change of 0.5 would be converted to -2). To quantify the percentages of genes that were correlated at the transcript and protein level fold changes were compared between the transcript and protein data. If the transcript and protein data both showed a fold change $\geq 1.5$ or $\leq-1.5$, that gene was considered correlated. If the transcript showed a fold change $\geq 1.5$ and the protein showed a fold change $\leq-1.5$, or vice versa, that gene was considered not correlated. If either the protein or transcript showed a fold change between -1.5 and 1.5 , that gene was considered neutral.

\section{Targeted gene expression}

A follow-up experiment was conducted to examine targeted gene expression of an inorganic phosphate transporter (NCBI \#: 323454760). Control, -P, and P-refed conditions were generated as discussed above. Cells were collected on a $0.2 \mu \mathrm{m}$ polycarbonate filter by vacuum filtration and immediately placed in $\mathrm{CTAB}$ extraction 
solution (Teknova, Hollister CA) amended by the addition of $1 \%$ mass/volume polyvinylpyrrolidone. Samples were stored at $-80^{\circ} \mathrm{C}$ until further processing.

Total RNA was isolated from each sample using the UltraClean® ${ }^{\mathbb{B}}$ Plant RNA Isolation Kit (MO BIO Laboratories, Inc., Carlsbad CA) using modified manufacturer's instructions. First, samples were centrifuged at 10,000 $\mathrm{x}$ g to separate cell lysate from the filter and $650 \mathrm{uL}$ of sample was transferred to a fresh $1.5 \mathrm{~mL}$ tube. Secondly, $300 \mu \mathrm{L}$ of PMR1 was added to each sample and mixed by vortexing followed by the addition of 800 $\mu \mathrm{L}$ of PMR4 to each sample and again mixed by vortexing. Finally, samples were loaded onto the columns and RNA extraction continued according to manufacturer's instructions. Isolated RNA was then treated with TURBO ${ }^{\mathrm{TM}}$ DNase (Ambion, Austin TX) to remove potential genomic DNA contamination and RNA was then quantified spectrophotometrically. A total of $100 \mathrm{ng}$ of RNA was primed with oligo dT primers and reverse transcribed into cDNA using the iScript Select cDNA Synthesis kit (Bio-Rad, Hercules CA). For each sample, a second reaction was performed in which no reverse transcriptase was added to serve as a control for genomic DNA contamination in subsequent analysis. These controls were all negative suggesting no contamination.

Species-specific primers were designed from genomic sequences using MacVector (MacVector, Inc., Cary NC). Amplicons were screened for secondary structure using Mfold software (Zuker 2003) to confirm the primers were $\mathrm{qPCR}$ compatible. A qRT-PCR assay was designed to optimize primer efficiency and examine relative abundance of cDNA transcripts across treatments using the comparative $C_{T}$ method (Livak and Schmittgen 2001). The $\Delta C_{T}\left(C_{T}\right.$ target $-C_{T}$ reference) was examined 
over a range of cDNA concentrations to ensure equal amplification efficiencies between target and reference amplicons. A plot of the $\log _{10}$ cDNA dilution versus $\Delta C_{T}$ was constructed to ensure the value of the slope did not differ significantly from zero. In this case, a constitutively expressed gene encoding an $A$. anophagefferens ubiquitinconjugating enzyme (UbE2) was used as a reference gene (Berg et al. 2008). For UbE2, primer sequences are 5': GCGAGCTCCAGGACTTTATG and 3': CGGGGTCGAGGAAGTAGAC with an amplification efficiency of $102.7 \%$ and amplicon size of 192 nucleotides. For the phosphate transporter, primer sequences are 5': CATCCTCTACGGCATCACCAAG and 3': ATCCAGAAGACGGAGTTGACGC with an amplification efficiency of $104.9 \%$ and 141 nucleotide amplicon size. Here, the reference condition was P-replete grown cells, the reference gene was UbE2, and the experimental treatments were $-\mathrm{P}$ grown cells and P-refed cells. Fold-change was determined using the Relative Expression Software Tool (REST) located at http://www.gene-quantification.de/download.html. REST accounts for differences in efficiency between primer sets when calculating fold changes. The $p$-values were determined by a pair-wise fixed reallocation randomization analysis (Pfaffl et al. 2002).

Polar membrane lipid analysis

The polar membrane lipid compositions of A. anophagefferens were examined using previously described approaches (Martin et al. 2011, Poppendorf et al. 2011). Briefly, batch cultures of $A$. anophagefferens strain CCMP 1984 were grown in either control or $-\mathrm{P}$ media as described above. Cells were harvested in log phase by filtration 
on GF/F filters, and immediately frozen in liquid nitrogen. Polar lipids were later extracted into dichloromethane (Martin et al. 2011) and analyzed by HPLC/MS/MS using normal phase chromatographic conditions on an Agilent 1200 HPLC coupled via an electrospray ionization source to a Thermo Vantage TSQ triple quadrupole mass spectrometer (Poppendorf et al. 2011).

\section{Results and Discussion}

Shotgun mass spectrometry was used to identify proteome responses to $\mathrm{P}$ deficiency. A total of 3,431 unique peptide identifications were made from 214,913 total spectra, with a false discovery rate of $0.6 \%$. From these data, 641 unique proteins (Table S1) were detected representing about $5.5 \%$ of the current 11,596 predicted gene models in the $A$. anophagefferens genome (see methods for description of statistical analyses). Although most of these proteins could be assigned a putative function, 37 could not and are listed as either hypothetical or predicted proteins (Table S1). A large percentage of the 641 proteins were annotated as ribosomal $(13.3 \%$ or 85 proteins, Table S1).

There were 46 different light harvesting complex (LHC) proteins detected out of the 62 encoded in the genome (Gobler et al. 2011) (Table S1). This is far more than detected in the proteome of the diatom $T$. pseudonana under optimal growth conditions, where a total of 14 different LHC homologues were identified [Nunn et al. 2009). $A$. anophagefferens is well adapted to low light conditions, reaching maximum growth rates at lower irradiances than its algal competitors, including the diatoms $T$. pseudonana, Phaeodactylum tricornutum and picoeukaryotes Ostreococcus tauri and O. lucimarinus 
(Gobler et al. 2011). This is consistent with the observation that $A$. anophagefferens has more unique LHC genes encoded in its genome than its algal competitors (Gobler et al. $2011)$.

\section{Differential protein abundance}

The abundance of the 641 proteins detected in this study were compared among treatments using spectral counting techniques. Out of the 641 proteins detected in this study, $49.6 \%$ (318 proteins) were differentially abundant in at least one treatment (control, -P, P-refed) relative to the other two based upon abundance score (see methods for description of statistical tests used to determine differentially abundant proteins) (Figure 1, Table S2). These 318 proteins were hierarchically clustered in order to group proteins with similar abundance patterns (Figure 2). The $-\mathrm{P}$ and P-refed treatments clustered together meaning the proteome of the P-refed treatment more closely resembled the proteome from the $-\mathrm{P}$ treatment than it did the control. Therefore, starting from a Pdeficient state, 24 hours was not enough time for $A$. anophagefferens to return to a replete nutrient proteome composition. The proteins grouped together into eight distinct regulation patterns across the three treatments (A-H; Figure 2).

\section{Highest abundance in control}

There were 75 proteins that were more abundant in the control condition relative to the $-\mathrm{P}$ and P-refed treatments (cluster A-B, Figure 2) and so are repressed during $\mathrm{P}$ deficiency. It appears that once phosphate is added to the $-\mathrm{P}$ cells, either these proteins 
remain repressed or there is a delay in their synthesis. The most abundant protein detected in this study, the large subunit of ribulose-1,5-bisphosphate carboxylase/oxygenase (RuBisCO), fell into this category (NCBI \#: 242620086) and was about 3.6-fold less abundant under -P conditions (Table S2). Also abundant in this study was a small chain RuBisCO protein (NCBI \#: 242620087). This protein was downregulated 4.2 fold under $-\mathrm{P}$ (Table S2). In the diatom T. pseudonana, a RuBisCO large subunit was among the most abundant proteins detected under optimal growth conditions as well (Nunn et al. 2009). Although carbon fixation was not specifically examined in this study, these protein abundance results suggest that carbon fixation is likely reduced when $\mathrm{P}$ is deficient in A. anophagefferens. In the P-refed treatment, both the RuBisCO large and small subunit proteins were more abundant than the $-\mathrm{P}$ treatment, but still low relative to the control. Thus carbon fixation likely increases after $\mathrm{P}$ deficiency is alleviated, but 24 hours was not enough time for carbon fixation in cells to fully recover.

A number of proteins with known roles in $\mathrm{N}$ metabolism were most abundant in the replete control (Figure 3, Table S2). A urease enzyme (NCBI \#: 323449776) was slightly less abundant in the $-\mathrm{P}$ treatment versus the control, although this result was not statistically significant. However, in the P-refed treatment, it was significantly 7-fold less abundant. Ureases are enzymes that break down urea into carbon dioxide and ammonia and are necessary for using urea as a potential $\mathrm{N}$ source. Urea, along with other organic $\mathrm{N}$ sources, is thought to play an important role in forming and sustaining $A$. anophagefferens blooms (Berg et al. 1997, Mulholland et al. 2002, Fan et al. 2003, Gobler et al. 2005). Also found in this cluster is a cyanase enzyme (NCBI \#: 
323447336). This cyanase was significantly less abundant under both -P and P-refed conditions. Cyanases hydrolyze cyanate, a byproduct of urea breakdown, into ammonia and carbon dioxide and have been shown to be important for obtaining $\mathrm{N}$ from cyanate in cyanobacteria (Kamennaya et al. 2008, Kammennaya and Post 2011). Additionally, an ammonium transporter (NCBI \#: 323457240) was found in this cluster and was over 4fold less abundant in $-\mathrm{P}$ and almost 2-fold less abundant in P-refed conditions. This ammonium transporter shows similarity to characterized ammonium transporters in Cylindrotheca fusiformis, where they are induced in N-deficient cells (Hildebrand 2005). Ammonium transporters in $A$. anophagefferens have also been shown to be transcriptionally up-regulated under N-deficient conditions (Berg et al. 2008, Wurch et al. 2011). Finally, an acetamidase/formamidase (NCBI \#: 323450867) is found in this cluster and is down-regulated 2.8-fold and 1.4-fold in the -P and P-refed treatments, respectively. In the coccolithophore Emiliania huxleyi, it was demonstrated that activities of acetamidase and formamidase increased under $\mathrm{N}$ deficiency (Palenik and Henson 1997). Transcriptome data showed an increase in an acetamidase/formamidase in A. anophagefferens under N-deficient conditions (Wurch et al. 2011). The lower abundance of these $\mathrm{N}$-metabolism proteins in the $-\mathrm{P}$ treatment suggests that $A$. anophagefferens may reduce its $\mathrm{N}$-scavenging machinery during $\mathrm{P}$ deficiency. The fact that these N-metabolism proteins are also low in the P-refed treatments suggests that once $\mathrm{P}$ deficiency is alleviated, the $\mathrm{N}$-scavenging machinery takes longer than 24 hours to respond. These results could have implications for utilizing $\mathrm{N}$ metabolism/scavenging 
proteins as markers of $\mathrm{N}$ deficiency in field populations, given that their expression may also be indirectly controlled by $\mathrm{P}$ availability.

Finally, a selenoprotein was also relatively more abundant in the control treatment. The $A$. anophagefferens genome appears to be enriched in genes encoding possible selenoproteins compared to other phytoplankton (Gobler et al. 2011). In this analysis, two putative selenoproteins were detected (NCBI \#: 323452479 and 323451867), although the specific peptides containing selenoresidues were not identified in these proteins (Table S2). However, this is not evidence that putative selenoproteins are not important or do not contain selenium in this organism because, typically, methods that detect selenoproteins require the use of LC-ICP-MS verification and sample processing techniques designed to avoid Se residue destruction (Ma et al. 2003, Ballihaut et al. 2007). Selenoprotein 323451867 was significantly more abundant in the control compared to the -P treatment while 323451979 was not abundant and did not show differential expression between these treatments. However, without knowledge of the function of these two selenoproteins, it is difficult to interpret these results.

\section{Highest abundance in P-refed}

The 33 proteins in clusters $\mathrm{C}$ and $\mathrm{E}$ are most abundant in the P-refed treatment and of lower abundance in the $-\mathrm{P}$ and/or control treatments (Figure 2). These proteins are induced after phosphate is re-supplied to P-deficient cells. Many of these proteins were slightly more abundant in the $-\mathrm{P}$ condition relative to the control (Cluster E, Figure 2). It could be that these proteins are induced when phosphate is unavailable and 
continue to be produced even after phosphate is re-supplied. One of these proteins is a putative sulfolipid biosynthesis protein (SQD1) that is 2.1 -fold more abundant under $-\mathrm{P}$ conditions (Figure 3, Table S2). In Arabidopsis thaliana, reduced phosphate availability increases SQD1 mRNA expression and protein product and leads to an increase in sulfolipid content (Essigmann et al. 1998). In the ocean, it has been demonstrated that some phytoplankton are able to reduce their $\mathrm{P}$ requirement by substituting P lipids with sulfolipids (Van Mooy et al. 2009). The differential abundance of this sulfolipid biosynthesis protein (NCBI \#: 323449174) suggests that $A$. anophagefferens employs a similar strategy of switching phospholipids for sulfolipids to adjust P quota. Analysis of the polar membrane lipids showed that cellular concentrations of the sulfolipid sulphoquinovosyldiacylglycerol (SQDG) was nearly 1.5fold greater in the $-\mathrm{P}$ condition versus the control condition $(2,864 \pm 29$ versus $2,001 \pm 29$ amol cell ${ }^{-1}$ ), while cellular phospholipids were approximately 8 -fold less (133 \pm 11 versus $1,104 \pm 41$ amol cell ${ }^{-1}$ ). In the P-refed condition, the putative sulfolipid biosynthesis protein was even more abundant (3.6 fold higher versus the control), than under the $-\mathrm{P}$ condition mentioned above ( 2.1 - fold) meaning induction continues even after 24 hours of experiencing excess levels of phosphate. This result is unexpected because in the diatom T. pseudonana, P-deficient cells reduced their non-P lipids from $\sim 43 \%$ to $\sim 7 \%$ of their total lipid content over a period of 24 hours once phosphate became available (Martin et al. 2010), suggesting that 24 hours would be enough time to observe a change in abundance of proteins involved in this lipid-switching response. An alternative explanation is that the P-lipids are scavenged immediately for their P, while the activity 
of the biosynthesis protein is post-translationally controlled. A delay in lipid switching response after P-addition could aid A. anophagefferens in maintaining lower P-quotas for longer time periods after nutrient pulses, perhaps conferring some advantage in their dynamic coastal environment where fluctuations between states of nutrient limitation could potentially be more rapid than in other areas.

Similar to $T$. pseudonana, we observed that $A$. anophagefferens also synthesizes the betaine lipid diacylglycerylcarboxyhydroxymethylcholine (DGCC) in response to $\mathrm{P}$ stress; concentrations of DGCC were 3,225 $\pm 39 \mathrm{amol} \mathrm{cell}^{-1}$ under $-\mathrm{P}$ conditions but were undetectable under control conditions $\left(<10\right.$ amol cell $\left.{ }^{-1}\right)$. The protein responsible for synthesis of the betaine lipid diacylglyceryltrimethylhomoserine (DGTS) has been identified in the green alga Chlamydomonas reinhardtii (BTA1Cr) (Riekhof et al. 2005), but both DGTS and homologs of BTA ICr are absent in A. anophagefferens. Very little is currently known of the synthesis of DGCC, although there is some evidence to suggest that, similar to DGTS, S-adenosyl methionine is a key intermediate in its synthesis (Kato et al. 2006). A time-course experiment that traced lipid composition in concert with SQD1 and putative DGCC synthases would help elucidate these aspects of $A$. anophagefferens $\mathrm{P}$ physiology.

\section{Lowest abundance in control}

There were 104 proteins generally more abundant in the $-\mathrm{P}$ and P-refed treatments relative to the control, falling into cluster $\mathrm{F}$ (Figure 2, Table S2). These proteins are more abundant when phosphate becomes deficient and continue to be present 
when $\mathrm{P}$ is resupplied. As such, proteins in this group are not actively degraded when phosphate is re-supplied to the $-\mathrm{P}$ cells and may continue to be produced. Within this cluster, 14 proteins are manually curated LHCs. LHC proteins are known to have variable regulation patterns in other algae. For example diatom genes encoding LHC-like proteins were significantly up-regulated in iron starved conditions (Allen et al. 2008). Additionally, a transcriptome profiling analysis in the coccolithophore E. huxleyi demonstrated down-regulation of an LHC-like protein during $\mathrm{N}$ starvation (Dyhrman et al. 2006). The 14 LHC-like proteins in this study were significantly more abundant in both the $-\mathrm{P}$ and P-refed treatments versus the control (Figure 3, Table S2). One of these 14 LHC-like proteins (NCBI\# 323457207) mapped to a gene that was previously shown to be up-regulated at the transcriptional level under general $\mathrm{N}$ and $\mathrm{P}$ stress (Wurch et al. 2011). It is difficult to predict whether these LHC proteins are involved in light harvesting, photoprotection, or some other physiological role and a more detailed study that quantifies RNA levels and protein levels in a variety of stress conditions would be needed to discern the variables governing LHC expression patterns.

Also in this cluster were 9 proteins involved in glycolysis, including a phosphoglucomutase (NCBI\#: 323452848), phosphoglucose isomerase (NCBI\#: 323455682), a triose phosphate isomerase (NCBI\#: 323447110), a glyceraldehyde-3phosphate dehydrogenase (NCBI\#: 323449032), an enolase (NCBI\#: 323453907), a pyruvate kinase (NCBI\#: 323450876), a UTP--glucose-1-phosphate uridylyltransferase (NCBI\#: 323452847), a nucleoside diphosphate kinase (NCBI\#: 323454769), and a phosphoenolpyruvate carboxylase (PEPC) (NCBI\#: 323453325) (Figure 2, Table S2). 
Glycolysis is the conversion of one molecule of glucose into two molecules of pyruvate, and requires 2 molecules of inorganic phosphate. Due to this P requirement, glycolysis enzyme activities in higher plants are affected by $\mathrm{P}$ supply in order to bypass those reactions that demand phosphate (see review: Paxton 1996). Based on the abundance patterns of these nine enzymes under -P and P-refed conditions, A. anophagefferens also appears to modulate or switch its glycolytic pathway in response to $\mathrm{P}$ supply. For example, PEPC can serve as a glycolytic bypass enzyme by diverting phosphoenolpyruvate (PEP) to oxaloacetate (OAA) and releasing inorganic phosphate. This bypass has been suggested in higher plants (Nagano et al. 1994) and the green alga Selenastrum minutum (Theodorou et al. 1991). OAA can then be converted to malate through the activity of malate dehydrogenase and eventually to pyruvate through a malic enzyme, thus completing the bypass of the ADP-requiring step of converting PEP directly to pyruvate catalyzed by pyruvate kinase (Paxton 1996). However, considering that two PKs (see below) were more abundant during -P conditions and no malic enzyme was detected in this study, it is difficult to interpret whether $A$. anophagefferens is using PEPC to bypass the ADP-requiring PK step of glycolysis, or simply liberating inorganic phosphate from PEP and replenishing tricarboxylic acid cycle intermediates.

Other proteins in the glycolysis pathway did not show differences in abundance among the three treatments (Table S1) while some showed differences, but did not fall into this particular cluster. For example, another pyruvate kinase (NCBI\#: 323453799) was 20 -fold more abundant under $-\mathrm{P}$ relative to the control, but only 5 -fold more abundant in P-refed conditions (Figure 2, Table S2), suggesting a stronger response to P 
re-supply relative to other glycolysis enzymes. Another glyceraldehyde-3-phosphate dehydrogenase (NCBI\#: 323455041) showed lowest abundance under -P and P-refed conditions, but highest abundances in the control treatment (Figure 2, Table S2). These results reflect the complexity of how $A$. anophagefferens is tailoring its glycolysis pathway to conserve $\mathrm{P}$, while still trying to meet its respiration demands.

A number of proteins with known roles in $\mathrm{P}$ metabolism are found in cluster $\mathrm{F}$, with lowest abundance in the control. Two inorganic phosphate transporters are significantly more abundant in both the $-\mathrm{P}$ and P-refed treatments (Figure 3, Table S2). One of the phosphate transporters (NCBI \#: 323454760) is 59-fold more abundant in the -P treatment and 50-fold more abundant in the P-refed treatment compared to the control, while the other phosphate transporter (NCBI \#: 323456737) is 7-fold more abundant in the $-\mathrm{P}$ treatment and 4-fold in the P-refed treatment) (Figure 3, Table S2). This suggests that $A$. anophagefferens makes more phosphate transporters when they are experiencing $\mathrm{P}$ starvation. Other eukaryotic algae have also been observed to employ this same strategy (Dyhrman et al. 2006, Chung et al. 2003). In the P-refed condition, these phosphate transporters are lower than $-\mathrm{P}$, but are still elevated relative to the control (Figure 3, Table S2). This is evidence of a lag between environmental changes and protein response and demonstrates that 24 hours is not enough time to observe a significant decrease in these phosphate transporters, possibly because these membrane proteins are not actively degraded.

To further explore this phenomenon, an additional experiment was performed to re-create control, $-\mathrm{P}$, and P-refed conditions and test whether or not expression of the 
more abundant phosphate transporter (NCBI \#: 323454760) changed at the transcriptional level over this 24 hour period (Figure 4). Results from this experiment demonstrate that the phosphate transporter transcript is up-regulated over 400 -fold under $-\mathrm{P}$ conditions relative to the control (Figure 4). After 24 hours of being re-fed phosphate, the transcript expression levels of the phosphate transporter were not detected (Figure 4). A biological replicate was examined for each condition and the results were similar with the phosphate transporter being up-regulated over 500-fold under -P and not detectable under P-refed conditions. In both P-refed biological replicates, the reference gene amplified in an efficient $\mathrm{C}_{\mathrm{T}}$ range, but the phosphate transporter did not amplify, indicating that the phosphate transporter transcript abundance was too low to detect, but the RNA and subsequent cDNA were of good quality. In the specific case of this phosphate transporter, the expression of mRNA is tightly linked to exogenous P concentrations, while the protein abundance appears to decay more slowly. Consequently, the interpretation of transcript and protein abundance measurements for this transporter should consider these timing differences, where the transcript could detect short-term $\mathrm{P}$ supply, and the protein would reflect the cell's physiological history as well as its current environment. While the slower decay of the phosphate transporter protein relative to its transcript may be due to the slower degradation of proteins associated with membranes (Hare and Taylor 1991), it is also possible that there has been little selection pressure to actively degrade this transporter versus allowing it to dilute away with growth and cell division. The observed persistence of the phosphate transporter for more than 24 hours after re-exposure to $\mathrm{P}$ would allow the cell to replenish its depleted phosphate cellular 
quota. Under this scenario, it seems likely that the transcriptome and proteome could have co-evolved their regulation to have an optimal response to environmental stimuli. It is interesting to note that this discrepancy between timing of transcripts and protein signals in this phosphate transporter is likely unidirectional: a short-term change to phosphate depleted conditions (instead of replete) would likely be detectable much more quickly on a protein level because there would not be a need to wait for the existing transporter protein to be diluted away by cellular division.

A 5'-nucleotidase (NCBI \#: 323455642) was also significantly more abundant in both -P (18-fold) and P-refed (23-fold) conditions versus the control. 5'-nucleotidase enzymes cleave the phosphate group from the 5 , end of the sugar moiety in nucleotides and may be used by algae to scavenge phosphate from exogenous nucleotides in the environment (Flynn et al. 1986, Dyhrman et al. 2003). Consistent with an extracellular function, SignalP (version 3.0) was used to determine that this 5 '-nucleotidase contains a signal peptide suggesting this protein is secreted (Bendtsen et al. 2004, Nielsen et al. 1997). Nucleotides released from grazing or cell lysis could potentially be a reservoir for $\mathrm{P}$ in the ocean with concentrations reaching 10-20 nM (Ammerman and Azam 1985). $A$. anophagefferens can utilize adenosine monophosphate (AMP) as a sole $\mathrm{P}$ source in culture (Wurch et al. 2011). These data, combined with the 5'-nucleotidase protein data in this study, suggests that nucleotides may be an important source of $\mathrm{P}$ for $A$. anophagefferens when DIP is scarce. As with the phosphate transporter proteins, the abundance of 5'-nucleotidase did not decline when cells were re-fed with $\mathrm{P}$ suggesting that the 5'-nucleotidase protein is not actively degraded upon $\mathrm{P}$ addition. 
Finally, a clathrin protein (NCBI \#: 323455486) was found in this cluster and was over 16-fold more abundant in -P and 21 -fold more abundant in the P-refed conditions versus the control. Recently, clathrin was shown to be one of the most abundant proteins in the diatom T. pseudonana (Nunn et al. 2009) and was also detected in a proteomic analysis of the coccolithophore E. huxleyi (Jones et al. 2010). Here, clathrin in $A$. anophagefferens was not only abundant, but was variable with higher abundances in the $\mathrm{P}$ and P-refed treatments relative to the control. Clathrin is the major coat protein of clathrin-coated vesicles (CCVs) (Pearse 1975). CCVs selectively sort and transport proteins and lipids from the outer membrane of cells to endosomes (see Kirchhausen 2000, Brodsky et al. 2001 for reviews of CCV formation and function). Clathrinmediated endocytosis (CME) is also a mechanism by which eukaryotic cells can internalize nutrients and other macromolecules (Conner and Schmid 2003). Given that CME can be a mechanism for internalizing nutrients, this protein could play a direct role in $\mathrm{P}$ scavenging from the environment. Alternatively, perhaps clathrin is involved in reconfiguring the lipid composition of cellular membranes since A. anophagefferens decreases phospholipids and increases non-phospholipids under $-\mathrm{P}$ conditions. The fact that clathrin has been shown to be abundant in diatoms, coccolithophores, and now the pelagophyte $A$. anophagefferens is intriguing and warrants further investigation (Nunn et al. 2009, Jones et al. 2010). 


\section{Highest abundance in $-P$}

There were 26 unique proteins that were most abundant under $-\mathrm{P}$ conditions and fall into clusters $\mathrm{G}$ and $\mathrm{H}$ (Figure 2, Table S2). These proteins are most abundant under $\mathrm{P}$ deficiency, but are rapidly turned over 24 hours after being refed phosphate. Four of these proteins are LHCs and their presence is consistent with the observation that LHC proteins in A. anophagefferens are induced during nutrient stress (Figure 3, Table S2). Proteins with known roles in $\mathrm{P}$ metabolism found in this cluster include an alkaline phosphatase (NCBI \#: 323455998) which increased 4.3-fold in -P versus control, and was not significantly different in the P-refed versus control (Figure 3, Table S2). Alkaline phosphatases cleave phosphate from a variety of organic molecules and are induced in other algae during P deficiency (Dyhrman and Palenic 1999, 2003, Fan et al. 2003). The induction of this alkaline phosphatase during P-deficient conditions suggests A. anophagefferens has the ability to utilize DOP compounds to meet its P demand when DIP is unavailable. After 24 hours of being re-fed P, the abundance of the alkaline phosphatase is similar to the control, suggesting rapid turnover or degradation of this protein upon release from $\mathrm{P}$ deficiency. This result is similar to findings from the coccolithophore, E. huxlevi, where alkaline phosphatase activity was induced under Pdeficient conditions, and this activity rapidly decreased 24 hours after cells were refed $\mathrm{P}$ (Dyhrman and Palenik 2003). This is in contrast to the $\mathrm{P}$ scavenging proteins that remain abundant in P-refed conditions (e.g. inorganic phosphate transporter and 5'-nucleotidase).

Alkaline phosphatase has been observed to be prone to loss from E. coli and a marine cyanobacterium (Malamy and Horecker 1961), and thus may be rapidly lost from 
the cell rather than being targeted specifically for degradation. Regardless, the disparities in duration among different P-deficient induced proteins after release from $\mathrm{P}$ deficiency are intriguing, and should be considered for interpreting protein presence and abundance in natural populations under conditions of non-steady state phosphate and DOP concentrations. In this case, the phosphate transporter and alkaline phosphatase would be indicative of $\mathrm{P}$ deficiency at different timescales. Furthermore, the induction of alkaline phosphatase under -P conditions, combined with the results from the 5'-nucleotidase discussed above, is consistent with the observation that at peak cell densities during $A$. anophagefferens blooms there is a significant drawdown of DOP (Gobler et al. 2004).

\section{Lowest abundance in $-P$}

The 80 proteins in cluster D are most abundant in the control and P-refed treatments and low abundance in the $-\mathrm{P}$ treatment (Figure 2). There are a few N-related proteins in this cluster, including a nitrate transporter (NCBI \#: 323448256), a nitrate and nitrite reductase (NCBI \#: 323453433 and 323453434 ) and a urea transporter (NCBI \#: 323451781) (Figure 3, Table S2). The down-regulation of these proteins under -P conditions is consistent with the $\mathrm{N}$ proteins discussed above. However, these proteins appear to be more responsive as they are relatively abundant again under P-refed conditions.

The majority of the proteins in this category are ribosomal (Figure 3, Table S2). Ribosomes are formed from ribosomal proteins along with ribosomal RNA, and are the macromolecular machines responsible for translation and protein syntheisis. Protein 
synthesis requires a large energy input. For example, up to $40 \%$ of E. coli's total cell energy turnover goes toward protein synthesis (Wilson and Nierhaus 2007). Therefore, protein synthesis must be tightly controlled to meet the biosynthetic demands of the cell and not waste resources on unnecessary protein synthesis. In A. anophagefferens there is a global down-regulation of ribosomal proteins during $\mathbf{P}$ deficiency. It is unclear whether this is a strategy to conserve resources, or a by-product of stationary growth. Once phosphate is available, these ribosomal proteins are immediately abundant again, suggesting that they are tightly coupled to the cell's growth environment and are indicative of nutrient availability to $A$. anophagefferens.

\section{Insights gained from P resupply}

Some P-responsive proteins decreased in abundance upon P resupply while others did not. This is likely a function of how quickly these proteins are degraded upon sensing a $\mathrm{P}$ supply increase. The variability in this turnover may be a function of the position of the protein within the cell, for example integral membrane proteins may be degraded slower since they are more difficult to access. Another explanation is that this time could also be a function of the protein's continued utility to the cell upon P resupply. Perhaps upon $\mathrm{P}$ addition it is advantageous to keep phosphate transporters in abundance for some time to take full advantage of the sudden increase. In contrast, alkaline phosphatase is no longer of utility once there is plenty of inorganic $\mathrm{P}$ available, and so this protein is quickly degraded. 
One of the primary aims of these types of studies is identifying genes and proteins that can be used as biomarkers of nutritional physiology in field populations. This study highlights the importance of including a refed treatment in such analyses. A simple $+\mathrm{P} /$ $\mathrm{P}$ only gives a snapshot of protein abundances. For example, both the phosphate transporter and alkaline phosphatase proteins were more abundant under -P conditions relative to the control. Without a P-refed treatment, both proteins would be considered equally good biomarkers for P deficiency. However, this study revealed that due to differences in protein turnover, these two proteins could provide information about different stages of P deficiency under non-steady state nutrient conditions such as during a bloom situation.

\section{Proteomeltranscriptome comparison}

A previous study examined the transcriptome of $A$. anophagefferens under nutrient replete (control) and $-\mathrm{P}$ conditions using Long Serial Analysis of Gene Expression (Long-SAGE) (Wurch et al. 2011). The transcriptome and proteome data were compared to examine choreography between the two datasets. Of the 641 unique proteins in this study, 257 were also present in the transcriptome (Table S3). An examination of the $-\mathrm{P}$ relative to control fold-change for both the transcript data (SAGE tag counts) and protein data (average abundance score) indicate that for some targets, the transcriptome and proteome responses are coordinated (Figure 5, Table S1). The inorganic phosphate transporter (NCBI \#: 323454760 ) and alkaline phosphatase (NCBI \#: 323455998) display significant up-regulation at both the transcript and protein levels 
(Figure 5). Less tightly linked, but still up-regulated in the $-\mathrm{P}$ treatment at both the transcript and protein levels are a 5'-nucleotidase (NCBI \#: 323455642) and clathrin (NCBI \#: 323455486) (Figure 5). No transcript data could be found for the sulfolipid biosynthesis protein from the Long-SAGE study (Wurch et al. 2011). Long-SAGE tags are generated at the most $3^{\prime}$ NLAIII site of an mRNA and are often found in the untranslated region (UTR) of an mRNA. The genome was searched in the 3 ' direction of the sulfolipid biosynthesis gene and no tag was found. A higher resolution (deeper sequencing) analysis or targeted gene expression assay would be needed to determine how the transcript is for this sulfolipid biosynthesis gene is regulated.

$\mathrm{N}$-metabolism and LHC genes show little correlation in expression patterns between transcript and protein levels. Ribosomal proteins tend to be ubiquitously downregulated under $-\mathrm{P}$ at the protein level, and for the most part, at the transcript level as well (Figure 5). Genes involved in protein degradation also appear to be somewhat choreographed with expression patterns at both the transcript and protein level indicating down-regulation under $-\mathrm{P}$ conditions (Figure 5, Table S3). This suggests that certain proteins are rapidly being turned over under nutrient replete conditions where growth rates are high. With the data available here, it is unclear as to which specific proteins are being targeted, and therefore difficult to put the expression patterns in context of adapting to $\mathrm{P}$ deficiency. Nonetheless, in order for an organism to change its proteome to adapt to variations in its environment, new proteins have to be made and proteins which are no longer needed must be recycled, and given the extensive proteome rearrangement 
observed here in response to $\mathrm{P}$ supply, it is not surprising that genes involved in protein degradation are also sensitive to $\mathrm{P}$ supply.

Although the actual fold changes are quite different between the transcripts and proteins for a given gene, 27.2 percent of the genes showed a "correlated" pattern (see methods). Approximately 58.4 percent of genes were considered "neutral", meaning the fold changes for either the transcript, protein, or both were less than 1.5 fold different from the control (Figure 5, Table SI). The patterns displayed by these "neutral" genes could partly be explained if there is a lag between the induction of transcripts and subsequent translation of proteins (e.g. high transcript, neutral protein) or the repression of transcripts and turnover of proteins (e.g. neutral transcript and high protein). In yeast it has recently been shown that transcriptional patterns 1-2 hours after treatment were best correlated with protein abundances 4-6 hours after treatment with the antibiotic rapamycin, supporting the idea of a lag between induction of transcripts and translation of proteins (Fournier et al. 2010). Furthermore, in yeast it was recently reported that an induction of mRNA due to osmotic stress is well correlated with an induction of proteins, but transcript reduction produced almost no change in the corresponding proteins (Lee et al. 2011). Clearly, a snap shot view of the transcriptome and proteome at the same time point would not give the most correlated pattern because the transcripts and proteins are being induced and degraded at different time scales. Only 14.4 percent of genes showed a "not correlated" pattern, where the transcript and protein fold changes were opposite. This result could be due to the transcript and protein data being generated from different 
biological samples, where slight variations in growth rate and point of harvest within the diel cycle could make a large difference in the expression patterns of certain genes.

The relative timing of the transcriptional and protein responses is biologically interesting and could be practically useful in interpreting expression patterns of both transcripts and proteins from environmental datasets. From culture studies, the expression patterns of certain genes can be linked to a cell's physiological condition. For example, the phosphate transporter discussed in this study is significantly up-regulated at both the transcript and protein level when $A$. anophagefferens experiences $\mathrm{P}$ deficiency. This gene could thus be used as a marker for examining $\mathrm{P}$ deficiency in natural populations. However, the abundance of the protein may have a different interpretation than the abundance of the transcript. In this example, the phosphate transporter protein was still abundant after the cells were exposed to replete $\mathrm{P}$, and its presence may indicate $P$ deficiency in the recent past and not necessarily the cell's current environment. The transcript for this phosphate transporter appeared to give finer resolution for assaying $\mathrm{P}$ deficiency, and its abundance may be more indicative of the cell's current geochemical environment. Conversely, since some genes are not being correlated, the abundance of a transcript may not equate to the protein being abundant and it would be difficult to infer activity, in a strictly temporal sense, based upon transcript abundance alone. These issues should be kept in mind when working with microbial community, metatranscriptomic, or metaproteomic datasets. 


\section{Conclusion}

This study examined the timing of global protein responses in algal cells subjected to, and then alleviated from, P deficiency. Throughout this study, a number of proteins were identified as being differentially regulated by $\mathrm{P}$ availability. $A$. anophagefferens increases its ability to scavenge or conserve P by: (1) up-regulating proteins involved in DOP acquisition, such as a 5'-nucleotidase and alkaline phosphatase; (2) increasing its ability to transport phosphate by up-regulating more phosphate transporters or switching to a more efficient phosphate transporter; (3) lower its $\mathrm{P}$ demand by switching sulfolipids for phospholipids; (4) and adjusting its glycolysis pathway. Insight into the timing of these responses was gained by examining protein abundances in a P-refed condition. In this case, many proteins were more abundant under P deficiency, but were not repressed 24 hours after being refed phosphate. This lag in response provides insight into the biological response to $\mathrm{P}$ deficiency, as well as the evolved coordination between transcript and protein expression. In addition, this lag has practical importance in the use of transcript and protein abundances as indicators of physiological state (e.g. P stress) in situ. If $\mathrm{P}$ acquisition proteins, like the phosphate transporter that is not quickly degraded, are abundant in a field sample, it may not be entirely reflective of the immediate $\mathrm{P}$ abundances in the environment in dynamic nonsteady state bloom conditions. Instead, it may be reflecting a previous environmental condition, or multiple different conditions integrated over time. These considerations are important for interpreting transcriptomic and proteomic profiles in metadatasets, particularly in relation to nutrient abundances. A comparison with the transcriptome 
shows that P-responsive proteins related to $\mathrm{P}$ metabolism/scavenging appear to be correlated. A time lag between the transcriptional responses versus the protein responses may account for those genes that are "neutral" or "not correlated". Finally, the breadth of response at both the transcriptome and proteome level of $A$. anophagefferens to $\mathrm{P}$ deficiency, combined with field observations of significant DOP drawdown during peak cell densities, suggest that $\mathrm{P}$ may play a more important role in brown tide formation, persistence and decline than previously thought.

\section{Acknowledgments}

Research for this work was supported by a National Oceanic and Atmospheric Administration ECOHAB grant (\#NA09NOS4780206) and National Science Foundation grant (\#OCE-0723667). Further support came from the Woods Hole Coastal Ocean Institute. LLW was supported by a Environmental Protection Agency STAR Fellowship (\#FP916901). EMB was supported by a National Science Foundation (NSF) Graduate Research Fellowship (\#2007037200) and an Environmental Protection Agency STAR Fellowship (\#F6E20324). We would like to thank Patrick Martin for assistance in harvesting samples for lipid analysis and Helen Fredricks for assistance with HPLC/MS/MS analysis of polar membrane lipids. We would also like to thank Sheean Haley for assistance with culturing and data interpretation. Finally, we would like to acknowledge Christopher Gobler for useful comments and feedback on the manuscript as well as his work on the genome of $A$. anophagefferens. 


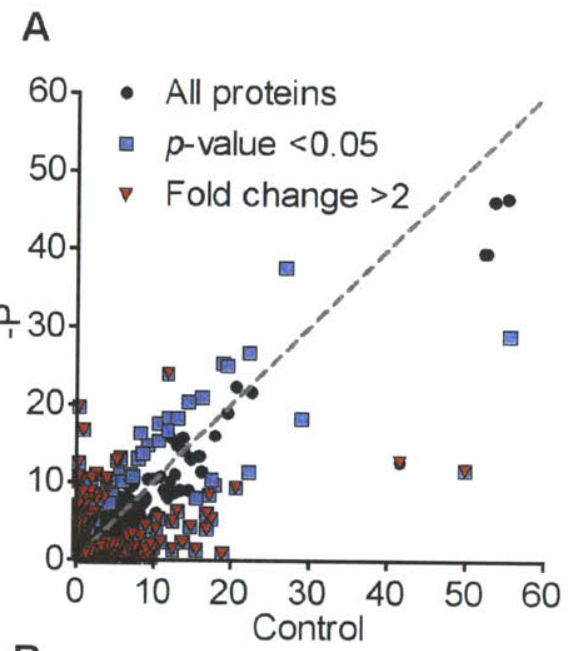

B

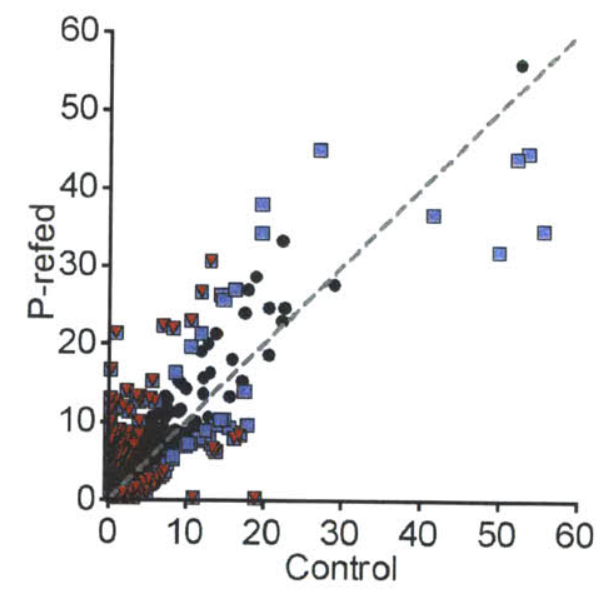

Figure 1. Scatter plot with the abundance of each protein in the (A) $-\mathrm{P}$ and control conditions and (B) P-refed and control conditions. Blue squares indicate proteins that are significantly different $(p$-value $<0.05)$ between the conditions based upon the Fisher exact test. Red triangles specify proteins that are greater than 2 -fold different between conditions. The gray dashed line indicates equal abundances between the conditions. 


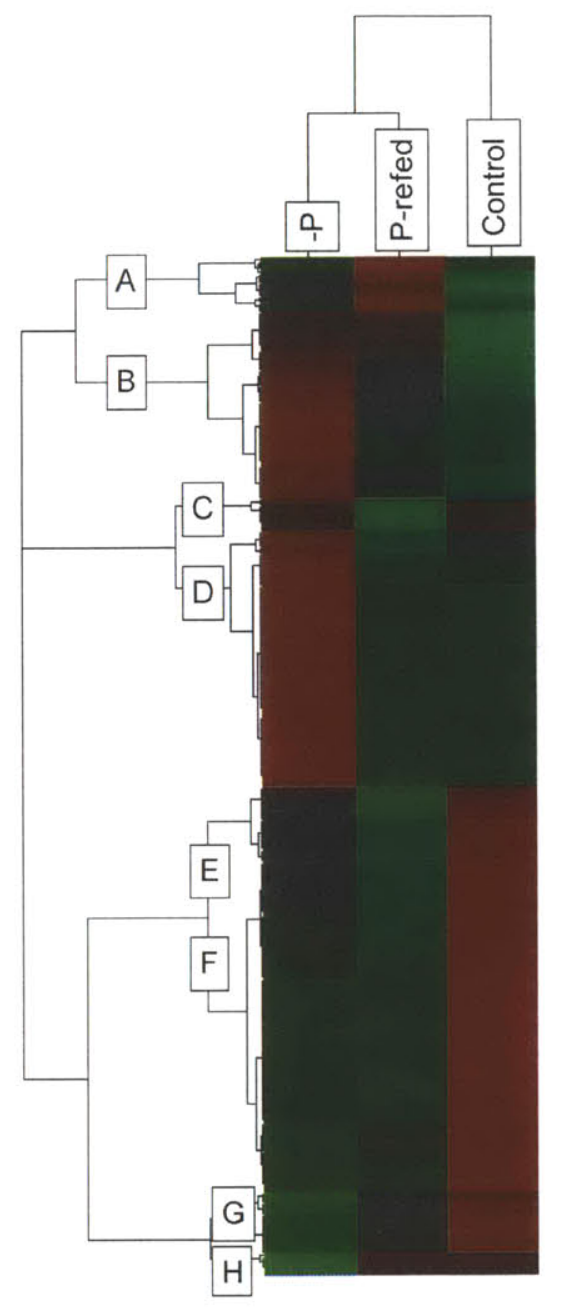

Figure 2. Hierarchical cluster analysis of the 318 proteins classified as differentially abundant. This analysis groups proteins by similarity of patterns. The spectral counts for each protein were averaged across treatments (-P, P-refed, control). Green indicates higher abundance than the mean while red indicates reduced abundance relative to the mean. Black indicates no difference from the mean. The intensity of the color is indicative of the degree of difference from the mean, with brighter colors displaying stronger differences. Letters indicate clusters of similar pattern. 


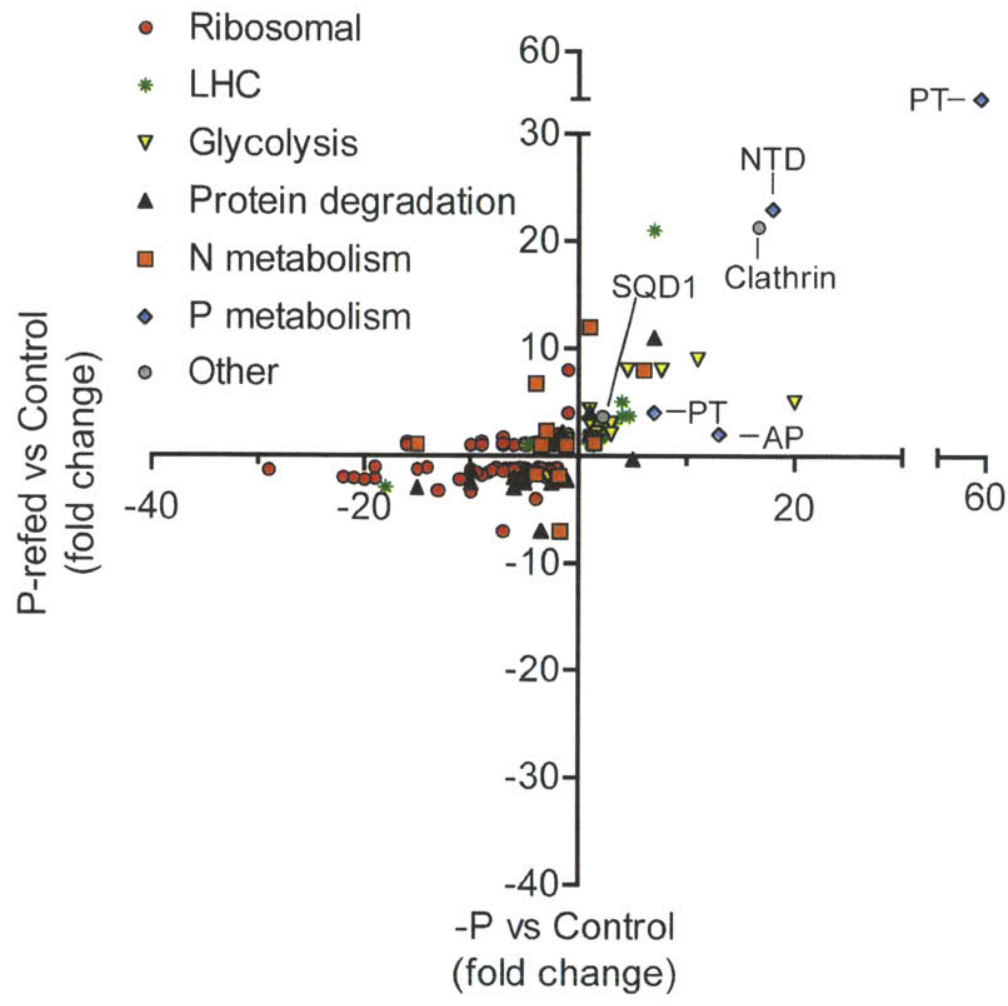

Figure 3. Scatter plot highlighting those proteins that fell into the categories of being putatively related to ribosomal, light harvesting complex-like (LHC), glycolysis, protein degradation, N-metabolism, P-metabolism, or other (e.g. clathrin). For those proteins involved in putative $\mathrm{P}$-metabolism, specific proteins are highlighted and include: PT: Inorganic phosphate transporter, SQD1: Sulfolipid biosynthesis gene, NTD: 5'-nucleotidase, AP: Alkaline phosphatase. Clathrin is also noted. Fold-changes were calculated relative to the control treatment. 


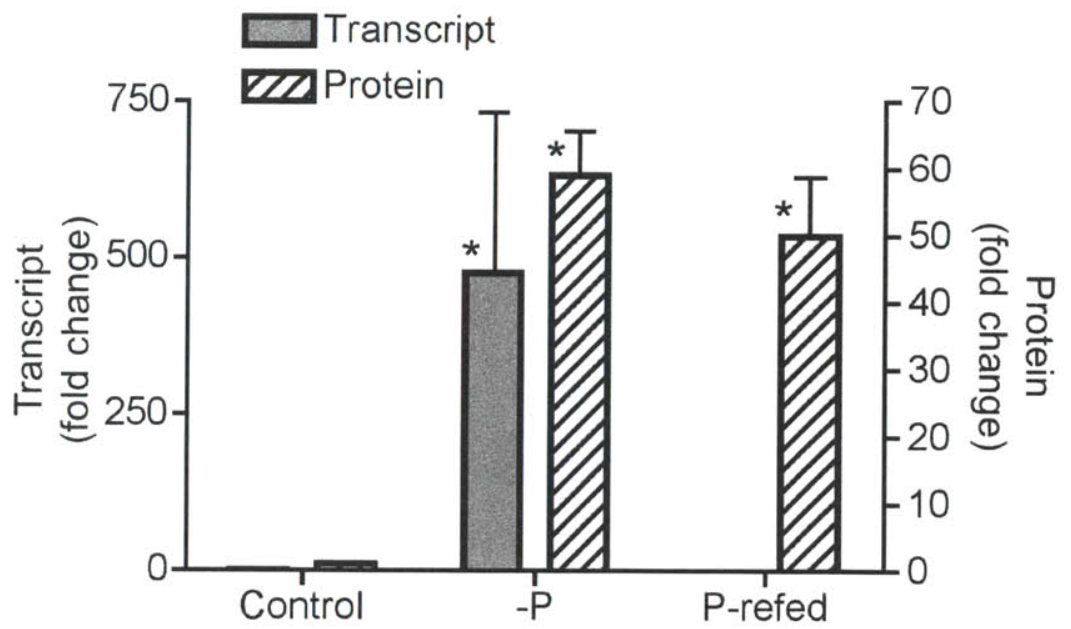

Figure 4. Bar graph comparing the expression of one inorganic phosphate transporter (NCBI \#: 323454760) at the transcriptional level and abundance at the protein level under control, -P and P-refed conditions. Transcript data are plotted as fold change relative to the control condition using the comparative $\mathrm{C}_{\mathrm{T}}$ method for qRT-PCR with a reference gene that encodes a ubiquitin-conjugating enzyme. Error bars for transcript data specify standard error of the average fold change of triplicate measurements on a single biological replicate between the sample condition (control, -P, P-refed) and the reference condition (control). Protein data are plotted as fold change relative to the control condition based upon spectral counts. Error bars for protein data specify standard error of the fold change among triplicate technical measurements of spectral counts for each condition. An asterisk $\left(^{*}\right)$ indicates that the fold change was significantly higher than the reference condition ( $p$-value of less than 0.05) based upon a pair-wise fixed reallocation randomization analysis for the transcript data and a Fisher exact test for the protein data. 


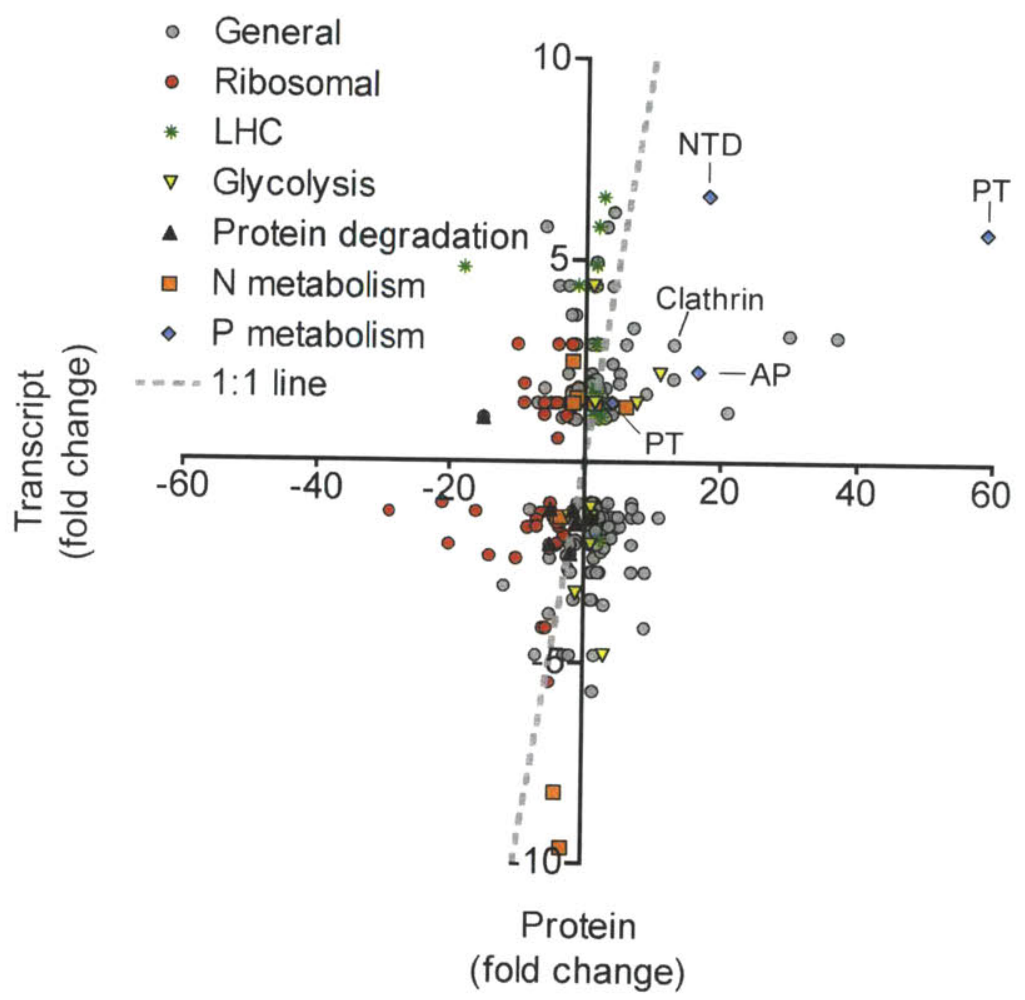

Figure 5. Scatter plot comparing the proteome data and transcriptome data in the $-\mathrm{P}$ treatment. All fold-changes are calculated relative to a control. The gray dashed line represents the 1:1 line. Data points falling on or near that line have similar regulation patterns at both the transcript and protein level. Specific protein IDs pointed out include: Clathrin, PT: Inorganic phosphate transporter, NTD: 5'-nucleotidase, and AP: Alkaline phosphatase. The sulfolipid biosynthesis protein (SQD1) was not represented in the transcriptome data. 


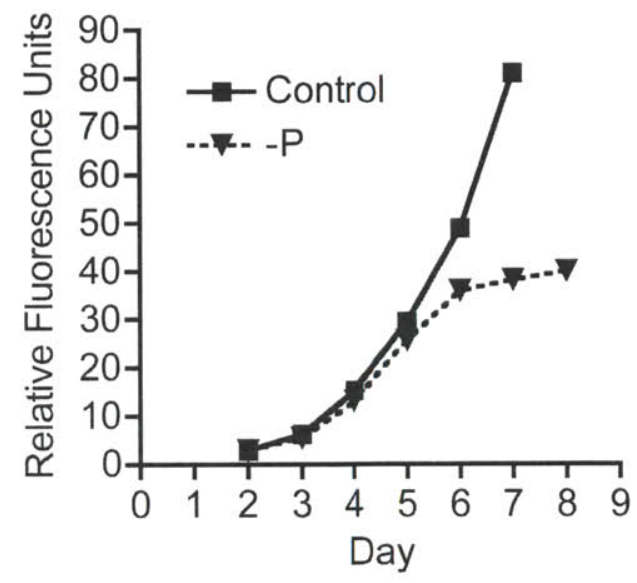

Figure S1. Growth of $A$. anophagefferens under nutrient replete (control) and P-deficient (-P) conditions plotted as Relative Fluorescence Units. The control treatment was harvested on day 6 . On day $8,-\mathrm{P}$ cells were harvested to generate the $-\mathrm{P}$ treatment. Remaining $-\mathrm{P}$ cells were re-fed phosphate and harvested 24 hours later to generate the P-refed treatment. 


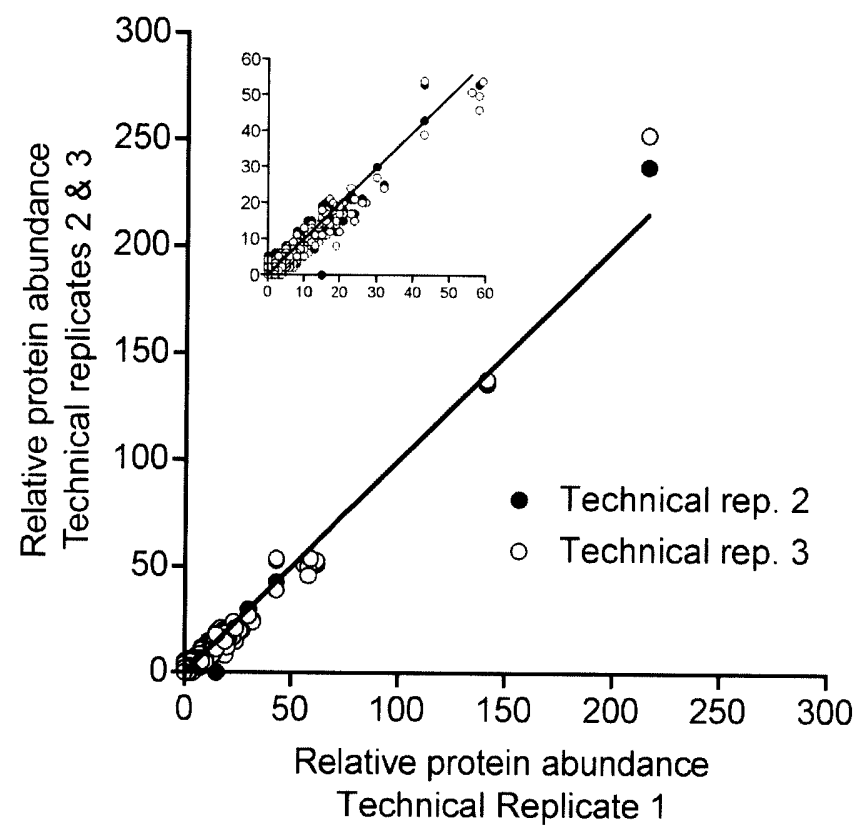

Figure S2. Scatter plot showing accuracy of method for spectral counting. Technical replicates of spectral count data from control conditions are plotted against each other. A 1:1 line is shown for comparison. 


\section{References}

Allen AE, LaRoche J, Maheswari U, Lommer M, Schauer N et al. (2008) Whole-cell response of the pinnate diatom Phaeodactylum tricornutum to iron starvation. Proceedings of the National Academy of Sciences of the United States of America 105: 10438-10443.

Ammerman JW, Azam F (1985) Bacterial 5'-nucleotidase in aquatic ecosystems - a novel mechanism of phosphorus regeneration. Science 227: 1338-1340.

Ballihaut G, Mounicou S, Lobinski R (2007) Multitechnique mass-spectrometric approach for the detection of bovine glutathione peroxidase selenoprotein: focus on the selenopeptide. Analytical and Bioanalytical Chemistry 388: 585-591.

Bendtsen JD, Nielsen H, von Heijne G, Brunak S (2004) Improved prediction of signal peptides: SignalP 3.0. Journal of Molecular Biology 340:783-795.

Berg GM, Glibert PM, Lomas MW, Burford MA (1997) Organic nitrogen uptake and growth by the chrysophyte Aureococcus anophagefferens during a brown tide event. Marine Biology 129: 377-387.

Berg, GM, Shrager J, Glockner G, Arrigo KR, Grossman AR (2008) Understanding nitrogen limitation in Aureococcus anophagefferens (Pelagophyceae) through cDNA and qRT-PCR analysis. Journal of Phycology 44: 1235-1249.

Birney E, Stamatoyannopoulos JA, Dutta A, Guigo R, Gingeras TR, et al. (2007) Identification and analysis of functional elements in $1 \%$ of the human genome by the ENCODE pilot project. Nature 447:799-816.

Brodsky FM, Chen CY, Knuehl C, Towler MC, Wakeham DE (2001) Biological basket weaving: formation and function of clathrin-coated vesicles. Annual Review of Cell and Developmental Biology 17: 517-568.

Chung CC, Hwang SPL, Chang J (2003) Identification of a high affinity phosphate transporter gene in a prasinophyte alga, Tetraselmis chui, and its expression under nutrient limitation. Applied and Environmental Microbiology 69: 754-759.

Conner SD, Schmid SL (2003) Regulated portals of entry into the cell. Nature 422: 3744.

Dennison WC, Marshall GJ, Wigand C (1989) Effects of "brown tide" shading on eelgrass (Zostera marina) distributions, p. 675-692. In E.M. Cosper, V.M. Bricelj, and E.J. Carpenter (eds.), Novel Phytoplankton Blooms: Causes and Impacts of Recurrent Brown Tides and Other Unusual Blooms, Volume 35. Springer, New York. 
Dyhrman ST, Palenik B (1999) Phosphate stress in cultures and field populations of the dinoflagellate Prorocentrum minimum detected by a single-cell alkaline phosphatase assay. Applied and Environmental Microbiology 65: 3205-3212.

Dyhrman ST, Palenik B (2003) Characterization of the ecoenzyme activity and phosphate-regulated proteins in the coccolithophorid Emiliania huxleyi. Journal of Plankton Research 25: 1215-1225.

Dyhrman ST, Haley ST, Birkeland SR, Wurch LL, Cipriano MJ et al. (2006) Long Serial Analysis of Gene Expression for gene discovery and transcriptome profiling in the widespread marine coccolithophore Emiliania huxleyi. Applied and Environmental Microbiology 72: 252-260.

Dyhrman ST (2008) Molecular approaches to diagnosing nutritional physiology in harmful algae: Implications for studying the effects of eutrophication. Harmful Algae 8: 167-174.

Eisen MB, Spellman PT, Brown PO, Botstein D (1998) Cluster analysis and display of genome-wide expression patterns. Proceedings of the National Academy of Sciences of the United States of America 95: 14863-14868.

Essigmann B, Güler S, Narang RA, Linke D, Benning C (1998) Phosphate availability affects the thylakoid lipid composition and the expression of SQDI, a gene required for sulfolipid biosynthesis in Arabidopsis thaliana. Proceedings of the National Academy of Sciences of the United States of America. 95: 1950-1955.

Fan C, Glibert PM, Alexander J, Lomas MW (2003) Characterization of urease activity in three marine phytoplankton species, Aureococcus anophagefferens, Prorocentrum minimum, and Thalassiosira weissflogii. Marine Biology 142: 949-958.

Fournier ML, Paulson A, Pavelka N, Mosley AL, Gaudenz K et al. (2010) Delayed correlation of mRNA and protein expression in rapamycin-treated cells and a role for $\mathrm{Ggcl}$ in cellular sensitivity to rapamycin. Molecular and Cellular Proteomics 9: 271-284. Gobler CJ, Sañudo-Wilhelmy SA (2001) Effects of organic carbon, organic nitrogen, inorganic nutrients, and iron additions on the growth of phytoplankton and bacteria during a brown tide bloom. Marine Ecology Progress Series 209: 19-34.

Flynn KJ, Opik H, Syrett PJ (1986) Localization of the alkaline phosphatase and 5'nucleotidase activities of the diatom Phaeodactylum tricornutum. Journal of General Microbiology. 132: 289-298.

Gobler C J, Renaghan MJ, Buck NJ (2002) Impacts of nutrients and grazing mortality on the abundance of Aureococcus anophagefferens during a New York brown tide bloom. Limnology and Oceanography 47: 129-141. 
Gobler CJ, Boneillo GE, Debenham C, Caron DA (2004) Nutrient limitation, organic matter cycling, and plankton dynamics during an Aureococcus anophagefferens bloom in Great South Bay, N.Y. Aquatic Microbial Ecology 35: 31-43.

Gobler CJ, Lonsdale DJ, Boyer GL (2005) A review of the causes, effects, and potential management of harmful brown tide blooms caused by Aureococcus anophagefferens (Hargraves et Sieburth). Estuaries: 28: 726-749.

Gobler C, Berry D, Dyhrman S, Wilhelm S, Salamov A et al. (2011) Niche of harmful alga Aureococcus anophagefferens revealed through ecogenomics. Proceedings of the National Academy of Sciences of the United States of America. 108: 4352-4357.

Greenfield DI, Lonsdale DJ (2002) Mortality and growth of juvenile hard clam Mercenaria mercenaria during brown tide. Marine Biology 141: 1045-1050.

Greenfield DI, Lonsdale DJ, Cerrato RM, Lopez GR (2004) Effects of background concentrations of Aureococcus anophagefferens (brown tide) on growth and feeding in the bivalve Mercenaria mercenaria. Marine Ecology Progress Series 274: 171-181.

Guillard RRL, Hargraves PE (1993) Stichochrysis immobilis is a diatom, not a chrysophyte. Phycologia 32: 234-236.

Hare, J.F. and K. Taylor, 1991. Mechanisms of plasma membrane protein degradation: Recycling proteins are degraded more rapidly than those onfined to the cell surface. Proc. Nail. Acad. Sci. 88:5902-5906.

Hildebrand M (2005) Cloning and functional characterization of ammonium transporters from the marine diatom Cylindrotheca fusiformis. Journal of Phycology 41: 105-113.

Jones BM, Edwards RJ, Skipp PJ, O’Connor CD, Iglesias-Rodriguez MD (2010) Shotgun proteomic analysis of Emiliania huxleyi, a marine phytoplankton species of major biogeochemical importance. Marine Biotechnology doi: 10.1007/s10126-010-9320-0.

Kall L, Storey JD, Noble WS (2008) Non-parametric estimation of posterior error probabilities associated with peptides identified by tandem mass spectrometry. Bioinformatics 24: 42-46.

Kana TM, Lomas MW, MacIntyre HL, Cornwell JC, Gobler CJ (2004) Stimulation of the brwon tide organism, Aureococcus anophagefferens, by selective nutrient additions to in situ mesocosms. Harmful Algae 3: 377-388.

Kamennaya NA, Chernihovsky M, Post AF (2008) The cyanate utilization capacity of marine unicellular Cyanobacteria. Limnology and Oceanography 53: 2485-2494. 
Kamennaya NA, Post AF (2011) Characterization of cyanate metabolism in marine Synechococcus and Prochlorococcus spp. Applied and Environmental Microbiology 77: 291-301.

Kato M, Kobayashi Y, Torii A, Yamada M (2006) Betaine lipids in marine algae. in Advanced research on plant lipids: proceedings of the 15th International Symposium on Plant Lipids., edited by N. Murata, pp. 19-22, Kluwer, Dordrecht.

Keller AA, Rice RL (1989) Effects of nutrient enrichment on natural populations of the brown tide phytoplankton Aureococcus anophagefferens (Chrysophyceae). Journal of Phycology 25: 636-646.

Keller A, Nesvizhskii AL, Kolker E, Aebersold R (2002) Empiracle statistical model to estimate the accuracy of peptide identifications made by MS/MS and database search. Analytical Chemistry 74: 5383-5392.

Kirchhausen T (2000) Clathrin. Annual Review of Biochemistry 69: 699-727.

LaRoche J, Nuzzi R, Waters R, Wyman, K, Falkowski PG, and Wallace DWR (1997) Brown tide blooms in Long Island's coastal waters linked to variability in groundwater flow. Global Change Biology 3: 397-410.

Lee MV, Topper SE, Hubler SL, Hose J, Wenger CD et al. (2011) A dynamic model of proteome changes reveals new roles for transcript alteration in yeast. Molecular Systems Biology 7: 514.

Livak KJ, Schmittgen TD (2001) Analysis of relative gene expression data using realtime quantitative PCR and the $2^{-\Delta \Delta C T}$ ) method. Methods 25:402-408.

Lu XN, Zhu HM (2005) Tube-gel digestion - A novel proteomic approach for high throughput analysis of membrane proteins. Molecular and Cellular Proteomics 4: 19481958.

Ma S, Caprioli RM, Hill KE, Burk RF (2003) Loss of selenium from selenoproteins: conversion of selenocysteine to dehydroalanine in vitro. Journal of the American Society for Mass Spectrometry 14: 593-600.

Malamy, M., and Horecker, B.L. (1961). The localization of alkaline phosphatase in E. coli, K12. Biochemical and Biophysical Research Communications 5: 104-108.

Martin P, Van Mooy BAS, Heithoff A, Dyhrman ST (2011) Phosphorus supply drives rapid turnover of membrane phospholipids in the diatom Thalassiosira pseudonanna. The ISME Journal 5: 1057-1060. 
Morris RM, Nunn BL, Frazar C, Goodlett DR, Ting YS, Rocap G (2010) Comparative metaproteomics reveals ocean-scale shifts in microbial nutrient utilization and energy transduction. The ISME Journal 4: 673-685.

Mulholland MR, Gobler CJ, Lee C (2002) Peptide hydrolysis, amino acid oxidation and $\mathrm{N}$ uptake in communities seasonally dominated by Aureococcus anophagefferens. Limnology and Oceanography 47: 1094-1108.

Nagano M, Hachiya A, Ashihara H (1994) Phosphate starvation and a glycolytic bypass catalyzed by phosphoenolpyruvate carboxylase in suspension cultured Catharanthus roseus cells. Zeitschrift für Naturforschung C-A Journal of Biosciences 49: 742-750.

Nielsen H, Engelbrecht J, Brunak S, von Heijne G (1997) Identification of prokaryotic and eukaryotic signal peptides and prediction of their cleavage sites. Protein Engineering 10:1-6.

Nunn BL, Aker JR, Shaffer SA, Tsai Y, Strzepek RF et al. (2009) Deciphering diatom biochemical pathways via whole-cell proteomics. Aquatic Microbial Ecology 55: 241253.

Palenik B, Henson SE (1997) The use of amides and other nitrogen sources by the phytoplankton Emiliania huxleyi. Limnology and Oceanography 42: 1544-1551.

Parker MS, Mock T, Armbrust EV (2008) Genomic insights into marine microalgae. Annual Review of Genetics 42: 619-645.

Paxton WC (1996) The organization and regulation of plant glycolysis. Annual Review of Plant Physiology and Plant Molecular Biology 47: 185-214.

Pearse BMF (1975) Coated vesicles from pig brain: purification and biochemical characterization. Journal of Molecular Biology 97:93-98.

Pfaffl MW, Horgan GW, Dempfle L (2002) Relative expression software tool (RESTC) for group-wise comparison and statistical analysis of relative expression results in realtime PCR. Nucleic Acids Research 30: e36 doi:10.1093/nar/30.9.e36.

Popendorf KJ, Lomas MW, Van Mooy BAS (2011), Microbial sources of intact polar diacylglycerolipids in the western North Atlantic Ocean. Organic Geochemistry. doi:10.1016/j.orggeochem.2011.05.003

Riekhof WR, Sears BB, Benning C (2005), Annotation of genes involved in glycerolipid biosynthesis in Chlamydomonas renhardtii: discovery of the betaine lipids synthase BTA1Cr. Eukaryotic Cell 4: 242-252. 
Saito MA, Bertrand EM, Dutkiewicz S, Bulygin VV, Moran DM et al. (2011) Iron conservation by reduction of metalloenzyme inventories in the marine diazotroph Crocosphaera watsonii. Proceedings of the National Academy of Sciences of the United States of America 108: 2184-2189.

Saldanha AJ (2004) Java Treeview - extensible visualization of microarray data. Bioinformatics 20: 3246-3248.

Sowell SM, Wilhelm LJ, Norbeck AD, Lipton MS, Nicora CD et al. (2009) Transport functions dominate the SAR 11 metaproteome at low-nutrient extremes in the Sargasso Sea. The ISME Journal 3: 93-105.

Sunda WG, Graneli E, Gobler CJ (2006) Positive feedback and the development and persistence of ecosystem disruptive algal blooms. Journal of Phycology 42: 963-974.

Theodorou ME, Elrifi IR, Turpin DH, Plaxton WC (1991) Effects of phosphorus limitation on respiratory metabolism in the green alga Selenastrum minutum. Plant Physiology 95:1089-1095.

Van Mooy BAS, Fredricks HF, Pedler BE, Dyhrman ST, Karl DM et al. (2009) Phytoplankton in the ocean use non-phosphorus lipids in response to phosphorus scarcity. Nature 458: 69-72.

Wilson DN, Nierhaus KH (2007) The weird and wonderful world of bacterial ribosome regulation. Critical Reviews in Biochemistry and Molecular Biology 42: 187-219.

Wurch LL, Haley ST, Orchard ED, Gobler CJ, Dyhrman ST (2011) Nutrient-regulated transcriptional responses in the brown tide forming algal Aureococcus anophagefferens. Environmental Microbiology 13: 468-481.

Zhang B, VerBerkmoes NC, Langston MA, Uberbacher E, Hettich RL, et al. (2006) Detecting differential and correlated protein expression in label-free shotgun proteomics. Journal of Proteome Research 5: 2909-2918.

Zuker M (2003) Mfold web server for nucleic acid folding and hybridization prediction. Nucleic Acids Research 31: 3406-3415. 


\begin{tabular}{|c|c|c|c|c|c|c|c|c|c|c|}
\hline \multirow[b]{2}{*}{ NCBI number } & \multirow{2}{*}{\multicolumn{2}{|c|}{ JGI protein }} & \multicolumn{3}{|c|}{ Mean of spectral counts } & \multicolumn{3}{|c|}{ Fisher Exact Test ( $P$-value) } & \multicolumn{2}{|c|}{ Fold Changes } \\
\hline & & & $-\mathrm{P}$ & P-refed & Control & $\begin{array}{l}\text { Cont vs } \\
-\mathrm{P}\end{array}$ & $\begin{array}{l}\text { Cont vs } \\
\text { Refeed }\end{array}$ & $\begin{array}{l}\text { Refeed } \\
\text { vs -P }\end{array}$ & $\begin{array}{l}\text { (-P/ } \\
\text { Control }\end{array}$ & $\begin{array}{l}\text { (Refeed/ } \\
\text { Control) }\end{array}$ \\
\hline 242620086 & & $\begin{array}{l}\text { Ribulose-1,5-bisphosphate } \\
\text { carboxylase/oxygenase large } \\
\text { subunit [Aureococcus } \\
\text { anophagefferens] }\end{array}$ & 64.000 & 105.333 & 235.667 & 0.000 & 0.000 & -0.020 & 0.272 & 0.447 \\
\hline 323455041 & 36610 & $\begin{array}{l}\text { Glyceraldehyde-3-phosphate } \\
\text { dehydrogenase }\end{array}$ & 61.667 & 68.333 & 138.333 & 0.000 & 0.000 & -0.023 & 0.446 & 0.494 \\
\hline 323453252 & 58968 & Transketolase & 46.667 & 73.667 & 55.333 & -0.370 & -0.170 & -0.092 & 0.843 & 1.331 \\
\hline 323447300 & 60370 & Histone & 39.667 & 56.000 & 52.667 & -0.100 & -0.140 & -0.410 & 0.753 & 1.063 \\
\hline 323447299 & 60369 & Histone & 46.333 & 44.667 & 53.667 & -0.450 & -0.001 & -0.003 & 0.863 & 0.832 \\
\hline 242620112 & & ATP synthase CFI beta chain & 39.667 & 44.000 & 52.333 & -0.110 & -0.001 & -0.058 & 0.758 & 0.841 \\
\hline 242620069 & & $\begin{array}{l}\text { photosystem II p680 } \\
\text { chlorophyll A apoprotein (CP- } \\
\text { 47) }\end{array}$ & 29.000 & 34.667 & 55.667 & 0.000 & 0.000 & -0.200 & 0.521 & 0.623 \\
\hline 323453579 & 71305 & Phosphoglycerate kinase & 37.667 & 45.000 & 27.000 & -0.001 & -0.011 & -0.170 & 1.395 & 1.667 \\
\hline 242620087 & & $\begin{array}{l}\text { Ribulose bisphosphate } \\
\text { carboxlyase small chain }\end{array}$ & 11.667 & 32.000 & 50.000 & 0.000 & 0.000 & 0.000 & 0.233 & 0.640 \\
\hline 323456332 & 36205 & Heat shock protein (Hsp 70) & 25.000 & 38.000 & 19.667 & -0.021 & -0.002 & -0.250 & 1.271 & 1.932 \\
\hline 242620034 & & ATP synthase CFI alpha chain & 18.333 & 27.667 & 29.000 & -0.030 & -0.076 & -0.310 & 0.632 & 0.954 \\
\hline 323456125 & 77959 & $\begin{array}{l}\text { Chloroplast light harvesting } \\
\text { protein }\end{array}$ & 25.333 & 28.667 & 19.000 & -0.011 & -0.100 & -0.130 & 1.333 & 1.509 \\
\hline 323450237 & 59236 & ATP synthase & 26.667 & 33.333 & 22.333 & -0.040 & -0.096 & -0.310 & 1.194 & 1.493 \\
\hline 323454637 & 59935 & Chaperonin ATPase & 19.000 & 34.333 & 19.667 & -0.350 & -0.012 & -0.049 & 0.966 & 1.746 \\
\hline 323448984 & 31888 & Ferredoxin NADP reductase & 21.667 & 24.667 & 22.667 & -0.350 & -0.300 & -0.170 & 0.956 & 1.088 \\
\hline 323457021 & 10068 & Hypothetical & 21.000 & 27.000 & 16.333 & -0.029 & -0.045 & -0.400 & 1.286 & 1.653 \\
\hline 323456170 & 69644 & \begin{tabular}{|l|} 
Adenosylhomocysteinase \\
\end{tabular} & 20.333 & 26.333 & 14.667 & -0.014 & -0.019 & -0.410 & 1.386 & 1.795 \\
\hline 323456989 & 59795 & $\begin{array}{l}\text { Fructose bisphosphate } \\
\text { aldolase }\end{array}$ & 16.000 & 27.000 & 18.000 & -0.520 & -0.120 & -0.140 & 0.889 & 1.500 \\
\hline 323451553 & 71821 & Glutamine synthetase & 14.667 & 30.667 & 13.333 & -0.180 & 0.000 & -0.011 & 1.100 & 2.300 \\
\hline 323455001 & 22269 & $\begin{array}{l}\text { Fructose bisphosphate } \\
\text { aldolase }\end{array}$ & 18.333 & 26.667 & 12.000 & -0.006 & -0.001 & -0.390 & 1.528 & 2.222 \\
\hline 323448136 & 72618 & Elongation factor & 11.333 & 23.000 & 22.333 & -0.005 & -0.210 & -0.033 & 0.507 & 1.030 \\
\hline 323449461 & 69930 & $\begin{array}{l}\text { Chloroplast light harvesting } \\
\text { protein }\end{array}$ & 24.000 & 21.333 & 12.000 & 0.000 & -0.036 & -0.008 & 2.000 & 1.778 \\
\hline 323450901 & 70239 & Actin & 17.667 & 23.000 & 10.667 & -0.003 & -0.003 & -0.440 & 1.656 & 2.156 \\
\hline 242620067 & & elongation factor $\mathrm{Tu}$ & 13.000 & 25.667 & 15.000 & -0.510 & -0.035 & -0.034 & 0.867 & 1.711 \\
\hline 323455179 & 59911 & $\begin{array}{l}\text { Peptidyl-prolyl cis-trans } \\
\text { isomerase }\end{array}$ & 15.667 & 21.333 & 14.000 & -0.150 & -0.130 & -0.540 & 1.119 & 1.524 \\
\hline 323456525 & 52245 & ATP synthase & 9.333 & 18.667 & 20.667 & -0.002 & -0.072 & -0.058 & 0.452 & 0.903 \\
\hline 323448027 & 60343 & $\begin{array}{l}\text { Chloroplast light harvesting } \\
\text { protein }\end{array}$ & 16.667 & 19.000 & 12.000 & -0.023 & -0.120 & -0.200 & 1.389 & 1.583 \\
\hline 323455979 & 69630 & ATPase & 5.333 & 24.000 & 17.667 & 0.000 & -0.280 & 0.000 & 0.302 & 1.358 \\
\hline 242620040 & & $\begin{array}{l}\text { photosystem II } 44 \mathrm{kDa} \\
\text { apoprotein (P6) }\end{array}$ & 18.333 & 16.333 & 13.333 & -0.020 & -0.510 & -0.019 & 1.375 & 1.225 \\
\hline 323448510 & 55209 & $\begin{array}{l}\text { S-adenosylmethionine } \\
\text { synthetase }\end{array}$ & 16.333 & 22.000 & 8.333 & -0.001 & 0.000 & -0.510 & 1.960 & 2.640 \\
\hline 323450741 & 65524 & $\begin{array}{l}\text { Carbamoyl-phosphate } \\
\text { synthase, Carboxyl } \\
\text { transferase. Biotin } \\
\text { carboxylase, Biotin binding } \\
\text { site }\end{array}$ & 11.000 & 20.000 & 13.000 & -0.480 & -0.130 & -0.110 & 0.846 & 1.538 \\
\hline 242620037 & & Hsp70-type chaperone & 15.333 & 19.667 & 10.667 & -0.021 & -0.030 & -0.420 & 1.438 & 1.844 \\
\hline 242620082 & & $\begin{array}{l}\text { photosystem I P700 } \\
\text { chlorophyll A apoprotein A1 }\end{array}$ & 10.333 & 14.000 & 17.667 & -0.041 & -0.027 & -0.540 & 0.585 & 0.792 \\
\hline 242620041 & & photosystem II D2 protein & 15.667 & 15.667 & 12.333 & -0.059 & -0.440 & -0.081 & 1.270 & 1.270 \\
\hline 323449102 & 59430 & ATP synthase & 13.333 & 18.000 & 16.000 & -0.440 & -0.410 & -0.520 & 0.833 & 1.125 \\
\hline 323455486 & 52498 & Clathrin vesicle coat & 16.667 & 21.333 & 1.000 & 0.000 & 0.000 & -0.410 & 16.667 & 21.333 \\
\hline
\end{tabular}




\begin{tabular}{|c|c|c|c|c|c|c|c|c|c|c|}
\hline 323452189 & 64431 & PT-repeat & 8.333 & 15.333 & 17.333 & -0.007 & -0.078 & -0.140 & 0.481 & 0.885 \\
\hline 323455687 & 70922 & $\begin{array}{l}\text { HMG1/2 (high mobility } \\
\text { group) box, Amino } \\
\text { acid/polyamine transporter II. } \\
\text { Transcription elongation } \\
\text { factor S-II. N-terminal }\end{array}$ & 11.000 & 22.333 & 7.000 & -0.025 & 0.000 & -0.035 & 1.571 & 3.190 \\
\hline 323447336 & 60366 & Cyanase & 9.667 & 9.667 & 18.000 & -0.018 & 0.000 & -0.150 & 0.537 & 0.537 \\
\hline 323454769 & 22626 & Nucleoside diphosphate kinase & 13.667 & 16.333 & 8.667 & -0.013 & -0.038 & -0.300 & 1.577 & 1.885 \\
\hline 323454760 & 22152 & $\begin{array}{l}\text { Inorganic phosphate } \\
\text { transporter }\end{array}$ & 19.667 & 16.667 & 0.000 & 0.000 & 0.000 & -0.009 & $\mathrm{~N} / \mathrm{A}^{\prime}$ & $\mathrm{N} / \mathrm{A}$ \\
\hline 323449723 & 30727 & $\begin{array}{l}\text { Photosystem 1 reaction center } \\
\text { subunit }\end{array}$ & 14.000 & 9.667 & 14.000 & -0.320 & -0.014 & -0.003 & 1.000 & 0.690 \\
\hline 323448531 & 72519 & Oxidoreductase & 15.333 & 8.000 & 13.333 & -0.130 & -0.004 & 0.000 & 1.150 & 0.600 \\
\hline 323451585 & 69835 & 14-3-3 protein & 10.333 & 15.000 & 9.333 & -0.230 & -0.140 & -0.440 & 1.107 & 1.607 \\
\hline 323454939 & 71070 & $\begin{array}{l}\text { Chloroplast light harvesting } \\
\text { protein }\end{array}$ & 14.667 & 11.667 & 9.333 & -0.011 & -0.490 & -0.011 & 1.571 & 1.250 \\
\hline 323447968 & 67669 & Zn-finger. RING & 8.000 & 9.333 & 15.667 & -0.017 & -0.002 & -0.340 & 0.511 & 0.596 \\
\hline 323447788 & 77845 & $\begin{array}{l}\text { Chloroplast light harvesting } \\
\text { protein }\end{array}$ & 10.333 & 14.333 & 10.000 & -0.310 & -0.270 & -0.520 & 1.033 & 1.433 \\
\hline 242620083 & & $\begin{array}{l}\text { photosystem I P700 } \\
\text { chlorophyll A apoprotein A2 }\end{array}$ & 9.000 & 10.333 & 14.667 & -0.084 & -0.014 & -0.300 & 0.614 & 0.705 \\
\hline 323448543 & 72529 & $\begin{array}{l}\text { Enolase (phosphopyruvate } \\
\text { dehydratase) }\end{array}$ & 6.000 & 8.667 & 17.000 & 0.000 & 0.000 & -0.490 & 0.353 & 0.510 \\
\hline 323448051 & 77848 & $\begin{array}{l}\text { Chloroplast light harvesting } \\
\text { protein }\end{array}$ & 13.000 & 11.333 & 8.000 & -0.012 & -0.310 & -0.036 & 1.625 & 1.417 \\
\hline 242620115 & & Cytochrome f & 10.667 & 9.333 & 11.000 & -0.400 & -0.110 & -0.056 & 0.970 & 0.848 \\
\hline 323453090 & 63510 & Aconitate hydratase & 12.667 & 13.000 & 5.333 & 0.000 & -0.010 & -0.130 & 2.375 & 2.438 \\
\hline 323451606 & 77816 & $\begin{array}{l}\text { Chloroplast light harvesting } \\
\text { protein }\end{array}$ & 8.000 & 15.333 & 9.000 & -0.540 & -0.091 & -0.110 & 0.889 & 1.704 \\
\hline 323446473 & 68712 & Expressed protein & 8.667 & 10.667 & 13.000 & -0.160 & -0.068 & -0.400 & 0.667 & 0.821 \\
\hline 323447782 & 33635 & Histone & 4.333 & 8.333 & 9.000 & -0.047 & -0.210 & -0.200 & 0.481 & 0.926 \\
\hline 323451957 & 37568 & $\begin{array}{l}\text { Rieske protein (Iron sulfur } \\
\text { protein). Chloroplast light } \\
\text { harvesting protein }\end{array}$ & 7.333 & 13.000 & 7.667 & -0.450 & -0.120 & -0.190 & 0.957 & 1.696 \\
\hline 323447684 & 33813 & Cytochrome c6 & 4.000 & 8.333 & 17.000 & 0.000 & 0.000 & -0.150 & 0.235 & 0.490 \\
\hline 242620091 & & Magnesium chelatase subunit & 9.667 & 13.333 & 7.333 & -0.098 & -0.073 & -0.530 & 1.318 & 1.818 \\
\hline 323447679 & 67892 & Hypothetical & 8.333 & 8.000 & 11.667 & -0.250 & -0.022 & -0.140 & 0.714 & 0.686 \\
\hline 323451317 & 37768 & $\begin{array}{l}\text { G-protein beta WD-40 repeat } \\
\text { (Guanine nucleotide-binding } \\
\text { protein) }\end{array}$ & 1.333 & 13.333 & 15.667 & 0.000 & -0.066 & 0.000 & 0.085 & 0.851 \\
\hline 323453907 & 24196 & $\begin{array}{l}\text { Enolase (phosphopyruvate } \\
\text { dehydratase) }\end{array}$ & 10.667 & 11.333 & 7.333 & -0.046 & -0.220 & -0.190 & 1.455 & 1.545 \\
\hline 323451650 & 27306 & $\begin{array}{l}\text { Chloroplast } \\
\text { hydroxymethylbilane synthase }\end{array}$ & 4.333 & 10.333 & 15.000 & 0.000 & -0.011 & -0.057 & 0.289 & 0.689 \\
\hline 242620031 & & $\begin{array}{l}\text { ATP synthase CF0 B'chain } \\
\text { subunit II }\end{array}$ & 9.000 & 10.000 & 11.333 & -0.390 & -0.130 & -0.260 & 0.794 & 0.882 \\
\hline 323453726 & 37153 & Chaperonin ATPase & 8.000 & 15.333 & 5.667 & -0.090 & -0.002 & -0.110 & 1.412 & 2.706 \\
\hline 323455658 & 69678 & Oxygen-evolving enlancer 1 & 9.333 & 11.000 & 7.000 & -0.097 & -0.200 & -0.330 & 1.333 & 1.571 \\
\hline 323449032 & 70352 & $\begin{array}{l}\text { Glyceraldehyde-3-phosphate } \\
\text { dehydrogenase }\end{array}$ & 10.000 & 12.667 & 6.000 & -0.021 & -0.030 & -0.430 & 1.667 & 2.111 \\
\hline 323452387 & 53694 & Ketol-acid reductoisomerase & 9.667 & 11.667 & 6.667 & -0.056 & -0.110 & -0.360 & 1.450 & 1.750 \\
\hline 242620075 & & Cytochrome c550 & 8.000 & 7.667 & 12.000 & -0.170 & -0.011 & -0.140 & 0.667 & 0.639 \\
\hline 323453500 & 69741 & ADP-ribosylation factor & 7.667 & 11.333 & 9.000 & -0.510 & -0.480 & -0.440 & 0.852 & 1.259 \\
\hline 323448862 & 38836 & $\begin{array}{l}\text { Carbamoyl-phosphate } \\
\text { synthase, Carboxyl } \\
\text { transferase, Biotin } \\
\text { carboxylase, Biotin/lipoyl } \\
\text { attachment } \\
\end{array}$ & 10.667 & 13.000 & 0.333 & 0.000 & 0.000 & -0.360 & 32.000 & 39.000 \\
\hline 242620119 & & $\begin{array}{l}\text { ATP-dependent clp protease } \\
\text { ATP-binding subunit }\end{array}$ & 7.333 & 12.000 & 7.000 & -0.340 & -0.120 & -0.290 & 1.048 & 1.714 \\
\hline 323450172 & 72073 & Peptidase & 6.000 & 11.667 & 7.667 & -0.410 & -0.230 & -0.140 & 0.783 & 1.522 \\
\hline 323453642 & 24591 & $\begin{array}{l}\text { O-acetylhomoserine/O- } \\
\text { acetylserine sulfhydrylase }\end{array}$ & 5.000 & 9.000 & 12.667 & -0.004 & -0.023 & -0.240 & 0.395 & 0.711 \\
\hline
\end{tabular}




\begin{tabular}{|c|c|c|c|c|c|c|c|c|c|c|}
\hline 323450799 & 71916 & $\begin{array}{l}\text { Kringle, PT-repeat, } \\
\text { Serine/threonine dehydratase }\end{array}$ & 6.000 & 8.667 & 10.333 & -0.100 & -0.110 & -0.490 & 0.581 & 0.839 \\
\hline 323452158 & 27009 & $\begin{array}{l}\text { Chloroplast light harvesting } \\
\text { protein }\end{array}$ & 9.333 & 12.667 & 4.000 & -0.003 & -0.002 & -0.540 & 2.333 & 3.167 \\
\hline 323445392 & 72895 & Mucin-2 precursor & 6.333 & 7.333 & 13.333 & -0.016 & -0.002 & -0.360 & 0.475 & 0.550 \\
\hline 242620120 & & $\begin{array}{l}\text { photosystem II Q(b) protein } \\
\text { (DI) }\end{array}$ & 7.333 & 9.000 & 8.667 & -0.500 & -0.350 & -0.410 & 0.846 & 1.038 \\
\hline 323456329 & 70752 & $\begin{array}{l}\text { Glutamate-1-semialdehyde } \\
\text { aminotransferase }\end{array}$ & 9.333 & 13.333 & 4.000 & -0.003 & -0.001 & -0.470 & 2.333 & 3.333 \\
\hline 323454246 & 69716 & $\begin{array}{l}\text { UDP-glucose 6- } \\
\text { dehydrogenase }\end{array}$ & 8.333 & 14.000 & 2.333 & 0.000 & 0.000 & -0.240 & 3.571 & 6.000 \\
\hline 323447374 & 34246 & $\begin{array}{l}\text { Ribulose-5-phosphate 3- } \\
\text { epimerase }\end{array}$ & 5.667 & 7.667 & 8.333 & -0.250 & -0.220 & -0.550 & 0.680 & 0.920 \\
\hline 323456872 & 60769 & $\begin{array}{l}\text { FAD linked oxidase. } \mathrm{N}- \\
\text { terminal }\end{array}$ & 10.333 & 12.000 & 2.000 & 0.000 & 0.000 & -0.300 & 5.167 & 6.000 \\
\hline 323445193 & 35642 & Histone & 5.333 & 7.333 & 10.667 & -0.040 & -0.028 & -0.560 & 0.500 & 0.688 \\
\hline 323454481 & 71195 & Sulfate adenylyltransferase & 13.000 & 6.000 & 5.667 & 0.000 & -0.420 & 0.000 & 2.294 & 1.059 \\
\hline 323457207 & 77828 & $\begin{array}{l}\text { Chloroplast light harvesting } \\
\text { protein }\end{array}$ & 10.000 & 10.000 & 5.333 & -0.009 & -0.096 & -0.140 & 1.875 & 1.875 \\
\hline 323449174 & 31507 & Sulfolipid biosynthesis protein & 8.000 & 13.333 & 3.667 & -0.008 & 0.000 & -0.260 & 2.182 & 3.636 \\
\hline 323452005 & 77832 & $\begin{array}{l}\text { Chloroplast light harvesting } \\
\text { protein }\end{array}$ & 10.333 & 10.000 & 4.000 & -0.001 & -0.019 & -0.110 & 2.583 & 2.500 \\
\hline 323452847 & 25732 & $\begin{array}{l}\text { UTP--glucose-1-phosphate } \\
\text { uridylyltransferase }\end{array}$ & 8.667 & 12.667 & 1.000 & 0.000 & 0.000 & -0.440 & 8.667 & 12.667 \\
\hline 323456453 & 20700 & Glutamine synthetase & 6.667 & 11.000 & 6.333 & -0.350 & -0.130 & -0.300 & 1.053 & 1.737 \\
\hline 323451419 & 37826 & Citrate synthase & 3.333 & 10.667 & 7.333 & -0.054 & -0.290 & -0.010 & 0.455 & 1.455 \\
\hline 323456364 & 59843 & Histone & 5.333 & 7.000 & 10.000 & -0.066 & -0.037 & -0.520 & 0.533 & 0.700 \\
\hline 323446545 & 77850 & $\begin{array}{l}\text { Chloroplast light harvesting } \\
\text { protein }\end{array}$ & 10.000 & 13.667 & 12.333 & -0.410 & -0.400 & -0.540 & 0.811 & 1.108 \\
\hline 323452848 & 25705 & Phosphoglucomutase & 10.000 & 11.667 & 0.667 & 0.000 & 0.000 & -0.310 & 15.000 & 17.500 \\
\hline 323450439 & 72012 & Chaperonin & 6.000 & 9.333 & 7.000 & -0.530 & -0.420 & -0.390 & 0.857 & 1.333 \\
\hline 323447358 & 77844 & $\begin{array}{l}\text { Chloroplast light harvesting } \\
\text { protein }\end{array}$ & 5.333 & 8.333 & 7.667 & -0.280 & -0.420 & -0.400 & 0.696 & 1.087 \\
\hline 323454334 & 77810 & $\begin{array}{l}\text { Chloroplast light harvesting } \\
\text { protein }\end{array}$ & 7.667 & 9.000 & 6.000 & -0.150 & -0.280 & -0.350 & 1.278 & 1.500 \\
\hline 323447744 & 55489 & $\begin{array}{l}\text { Chloroplast light harvesting } \\
\text { protein }\end{array}$ & 7.667 & 7.333 & 6.333 & -0.190 & -0.510 & -0.150 & 1.211 & 1.158 \\
\hline 323450268 & 29808 & $\begin{array}{l}\text { Flavin-containing } \\
\text { monooxygenase-like }\end{array}$ & 12.333 & 10,000 & 0.000 & 0.000 & 0.000 & -0.023 & $\mathrm{~N} / \mathrm{A}$ & $\mathrm{N} / \mathrm{A}$ \\
\hline 323455568 & 77960 & $\begin{array}{l}\text { Chloroplast light harvesting } \\
\text { protein }\end{array}$ & 8.000 & 9.000 & 6.333 & -0.150 & -0.340 & -0.290 & 1.263 & 1.421 \\
\hline 323455382 & 61597 & $\begin{array}{l}\text { Dynein heavy chain. AAA } \\
\text { ATPase }\end{array}$ & 7.333 & 8.667 & 4.333 & -0.042 & -0.087 & -0.360 & 1.692 & 2.000 \\
\hline 323454019 & 77822 & $\begin{array}{l}\text { Chloroplast light harvesting } \\
\text { protein }\end{array}$ & 6.333 & 7.333 & 5.333 & -0.240 & -0.400 & -0.360 & 1.188 & 1.375 \\
\hline 323453856 & 6122 & Ribosomal protein L6E & 1.667 & 8.000 & 10.000 & 0.000 & -0.087 & -0.004 & 0.167 & 0.800 \\
\hline 323456180 & 52316 & Ribosomal protein L5 & 2.333 & 6.333 & 14.000 & 0.000 & 0.000 & -0.080 & 0.167 & 0.452 \\
\hline 323452815 & 60076 & Ribosomal protein L4/Lle & 1.333 & 8.333 & 12.667 & 0.000 & -0.012 & -0.001 & 0.105 & 0.658 \\
\hline 323453541 & 24359 & Pyruvate kinase & 6.333 & 9.667 & 5.667 & -0.290 & -0.160 & -0.410 & 1.118 & 1.706 \\
\hline 323452454 & 71657 & Xanthine dehydrogenase & 11.000 & 4.667 & 5.667 & -0.005 & -0.190 & 0.000 & 1.941 & 0.824 \\
\hline 242620038 & & $\begin{array}{l}\text { Photosystem I reaction center } \\
\text { subunit II }\end{array}$ & 7.667 & 7.333 & 7.000 & -0.280 & -0.380 & -0.150 & 1.095 & 1.048 \\
\hline 323450616 & 65502 & Pyruvate carboxylase & 7.667 & 11.333 & 2.667 & -0.002 & 0.000 & -0.440 & 2.875 & 4.250 \\
\hline 323450905 & 71945 & $\begin{array}{l}\text { Endonuclease/exonuclease/ph } \\
\text { osphatase }\end{array}$ & 11.000 & 8.667 & 2.667 & 0.000 & -0.007 & -0.024 & 4.125 & 3.250 \\
\hline 323452472 & 60091 & $\begin{array}{l}\text { Chloroplast light harvesting } \\
\text { protein }\end{array}$ & 10.333 & 8.333 & 4.000 & -0.001 & -0.076 & -0.034 & 2.583 & 2.083 \\
\hline 323454267 & 77759 & Inositol phosphatase & 7.333 & 7.000 & 5.333 & -0.120 & -0.460 & -0.150 & 1.375 & 1.313 \\
\hline 323456600 & 52193 & $\begin{array}{l}\text { Ribosomal protein L30. L7, } \\
\text { Peptidase }\end{array}$ & 4.000 & 7.333 & 10.333 & -0.009 & -0.038 & -0.260 & 0.387 & 0.710 \\
\hline 323457284 & 60527 & $\begin{array}{l}\text { Mucin-associated surface } \\
\text { protein }\end{array}$ & 8.667 & 8.000 & 4.667 & -0.016 & -0.180 & -0.110 & 1.857 & 1.714 \\
\hline 323456271 & 77805 & $\begin{array}{l}\text { Chloroplast light harvesting } \\
\text { protein }\end{array}$ & 10.000 & 7.667 & 4.000 & -0.001 & -0.120 & -0.025 & 2.500 & 1.917 \\
\hline 323449755 & 30726 & Amino transferase class-III & 10.000 & 11.667 & 0.000 & 0.000 & 0.000 & -0.310 & N/A & $\mathrm{N} / \mathrm{A}$ \\
\hline
\end{tabular}




\begin{tabular}{|c|c|c|c|c|c|c|c|c|c|c|}
\hline 323454635 & 23580 & $\begin{array}{l}\text { Chloroplast 3-oxoacyl-[acyl- } \\
\text { carrier protein] reductase } \\
\text { orecursor }\end{array}$ & 4.667 & 8.333 & 7.333 & -0.210 & -0.480 & -0.260 & 0.636 & 1.136 \\
\hline 323449750 & 38422 & $\begin{array}{l}\text { Chloroplast light harvesting } \\
\text { protein }\end{array}$ & 8.333 & 7.333 & 4.667 & -0.023 & -0.270 & -0.088 & 1.786 & 1.571 \\
\hline 323447058 & 68367 & Hypothetical protein & 1.000 & 0.333 & 19.000 & 0.000 & 0.000 & -0.210 & 0.053 & 0.018 \\
\hline 323448850 & 31983 & Ribosomal protein & 2.000 & 8.000 & 9.667 & 0.000 & -0.110 & -0.009 & 0.207 & 0.828 \\
\hline 323454622 & 23768 & Ubiquitin & 4.333 & 8.000 & 8.333 & -0.079 & -0.260 & -0.240 & 0.520 & 0.960 \\
\hline 323452479 & 78109 & Selenoprotein & 5.333 & 5.667 & 8.333 & -0.200 & -0.046 & -0.290 & 0.640 & 0.680 \\
\hline 323453956 & 77824 & $\begin{array}{l}\text { Chloroplast light harvesting } \\
\text { protein }\end{array}$ & 6.000 & 7.333 & 4.667 & -0.190 & -0.270 & -0.430 & 1.286 & 1.571 \\
\hline 323451749 & 64743 & $\begin{array}{l}\text { Calcium-binding EF-hand, } \\
\text { Pleckstrin-like, LMBR 1-like } \\
\text { conserved region }\end{array}$ & 6.333 & 7.667 & 6.000 & -0.350 & -0.490 & -0.410 & 1.056 & 1.278 \\
\hline 323450447 & 77838 & $\begin{array}{l}\text { Chloroplast light harvesting } \\
\text { protein }\end{array}$ & 6.333 & 8.333 & 5.333 & -0.240 & -0.250 & -0.510 & 1.188 & 1.563 \\
\hline 323451960 & 77831 & $\begin{array}{l}\text { Chloroplast light harvesting } \\
\text { protein }\end{array}$ & 7.000 & 8.000 & 4.667 & -0.083 & -0.180 & -0.330 & 1.500 & 1.714 \\
\hline 323455169 & 5527 & Ribosomal protein & 0.667 & 8.667 & 9.333 & 0.000 & -0.210 & 0.000 & 0.071 & 0.929 \\
\hline 323450465 & 60205 & Ribosomal protein L18 & 1.667 & 8.667 & 7.000 & -0.003 & -0.520 & -0.002 & 0.238 & 1.238 \\
\hline 323453622 & 24147 & $\begin{array}{l}\text { Phosphoserine } \\
\text { aminotransferase }\end{array}$ & 3.000 & 8.667 & 6.667 & -0.062 & -0.460 & -0.032 & 0.450 & 1.300 \\
\hline 323455964 & 20379 & Ribosomal protein & 1.667 & 8.333 & 7.667 & -0.001 & -0.420 & -0.003 & 0.217 & 1.087 \\
\hline 242620081 & & cytochrome b559 alpha chain & 3.333 & 3.667 & 5.667 & -0.200 & -0.076 & -0.390 & 0.588 & 0.647 \\
\hline 323449769 & 30589 & Ribosomal protein & 3.000 & 7.000 & 8.333 & -0.012 & -0.140 & -0.120 & 0.360 & 0.840 \\
\hline 323448873 & 38843 & Ribosomal protein & 1.333 & 7.667 & 9.000 & 0.000 & -0.140 & -0.002 & 0.148 & 0.852 \\
\hline 323456798 & 70540 & $\begin{array}{l}\text { Chloroplast light harvesting } \\
\text { protein }\end{array}$ & 7.000 & 6.000 & 5.333 & -0.150 & -0.490 & -0.098 & 1.313 & 1.125 \\
\hline 323445949 & 70003 & Ribosomal protein & 1.000 & 7.000 & 7.667 & 0.000 & -0.220 & -0.002 & 0.130 & 0.913 \\
\hline 323451525 & 69840 & $\begin{array}{l}\text { Chloroplast light harvesting } \\
\text { protein }\end{array}$ & 5.333 & 8.000 & 4.333 & -0.240 & -0.140 & -0.450 & 1.231 & 1.846 \\
\hline 323457181 & 69604 & Ribosomal protein & 0.000 & 7.333 & 9.667 & 0.000 & -0.067 & 0.000 & 0.000 & 0.759 \\
\hline 323454031 & 23855 & $\begin{array}{l}\text { Chloroplast light harvesting } \\
\text { protein }\end{array}$ & 7.000 & 7.333 & 3.667 & -0.025 & -0.110 & -0.240 & 1.909 & 2.000 \\
\hline 323455981 & 59810 & $\begin{array}{l}\text { Chloroplast light harvesting } \\
\text { protein }\end{array}$ & 6.667 & 7.000 & 4.333 & -0.080 & -0.250 & -0.250 & 1.538 & 1.615 \\
\hline 323450876 & 28850 & Pyruvate kinase & 7.667 & 8.000 & 1.000 & 0.000 & 0.000 & -0.220 & 7.667 & 8.000 \\
\hline 323451948 & 4875 & Ribosomal protein & 3.000 & 8.667 & 5.667 & -0.150 & -0.270 & -0.032 & 0.529 & 1.529 \\
\hline 323454655 & 77806 & $\begin{array}{l}\text { Chloroplast light harvesting } \\
\text { protein }\end{array}$ & 6.000 & 6.000 & 4.000 & -0.100 & -0.340 & -0.220 & 1.500 & 1.500 \\
\hline 323453816 & 77825 & $\begin{array}{l}\text { Chloroplast light harvesting } \\
\text { protein }\end{array}$ & 7.667 & 6.333 & 4.000 & -0.019 & -0.290 & -0.071 & 1.917 & 1.583 \\
\hline 323457186 & 18502 & $\begin{array}{l}\text { 3-isopropylmalate } \\
\text { deliydrogenase }\end{array}$ & 5.000 & 5.667 & 6.000 & -0.510 & -0.290 & -0.360 & 0.833 & 0.944 \\
\hline 323454039 & 36932 & Translation elongation factor & 2.667 & 6.667 & 6.667 & -0.038 & -0.330 & -0.098 & 0.400 & 1.000 \\
\hline 323450925 & 60177 & Ribosomal protein & 1.000 & 5.333 & 8.333 & 0.000 & -0.033 & -0.014 & 0.120 & 0.640 \\
\hline 323451995 & 59038 & Triosephosphate isomerase & 6.667 & 5.667 & 4.000 & -0.055 & -0.400 & -0.100 & 1.667 & 1.417 \\
\hline 323450518 & 59217 & $\begin{array}{l}\text { Rieske protein (Iron sulfur } \\
\text { protein) }\end{array}$ & 6.000 & 7.667 & 2.333 & -0.010 & -0.011 & -0.480 & 2.571 & 3.286 \\
\hline 323457115 & 19513 & $\begin{array}{l}\text { Chloroplast precursor } \\
\mathrm{CbxX} / \mathrm{Cfq} \mathrm{X}\end{array}$ & 7.667 & 6.667 & 1.667 & 0.000 & -0.008 & -0.093 & 4.600 & 4.000 \\
\hline 323445826 & 69058 & Hypothetical protein & 5.667 & 5.333 & 5.000 & -0.300 & -0.440 & -0.190 & 1.133 & 1.067 \\
\hline 323449647 & 66270 & Oxidoreductase & 5.000 & 6.667 & 4.000 & -0.240 & -0.240 & -0.540 & 1.250 & 1.667 \\
\hline 323455325 & 61510 & Hypothetical protein & 5.667 & 4.667 & 4.000 & -0.140 & -0.550 & -0.110 & 1.417 & 1.167 \\
\hline 323451117 & 28296 & Ribosomal protein & 2.000 & 7.667 & 6.000 & -0.024 & -0.490 & -0.013 & 0.333 & 1.278 \\
\hline 323448922 & 77815 & $\begin{array}{l}\text { Chloroplast light harvesting } \\
\text { protein }\end{array}$ & 4.667 & 5.667 & 2.667 & -0.086 & -0.130 & -0.440 & 1.750 & 2.125 \\
\hline 323455846 & 70817 & Sodium/Calcium exchanger & 3.333 & 5.333 & 5.667 & -0.200 & -0.300 & -0.420 & 0.588 & 0.941 \\
\hline 323447987 & 59574 & $\begin{array}{l}\text { Pyridoxal-5'-phosphate- } \\
\text { dependent enzyme, beta } \\
\text { subunit }\end{array}$ & 4.667 & 3.667 & 6.667 & -0.310 & -0.025 & -0.120 & 0.700 & 0.550 \\
\hline 323454183 & 36703 & $\begin{array}{l}\text { Amino transferase class-I and } \\
\text { II }\end{array}$ & 5.333 & 8.667 & 1.667 & -0.006 & -0.001 & -0.350 & 3.200 & 5.200 \\
\hline 323456156 & 36157 & Translation elongation factor & 4.333 & 5.000 & 5.000 & -0.560 & -0.370 & -0.400 & 0.867 & 1.000 \\
\hline 323451429 & 77817 & $\begin{array}{l}\text { Chloroplast light harvesting } \\
\text { protein }\end{array}$ & 5.000 & 5.333 & 5.000 & -0.440 & -0.440 & -0.310 & 1.000 & 1.067 \\
\hline
\end{tabular}




\begin{tabular}{|c|c|c|c|c|c|c|c|c|c|c|}
\hline 323452321 & 71636 & ATP-dependent Clp protease & 3.667 & 6.667 & 3.333 & -0.390 & -0.130 & -0.280 & 1.100 & 2.000 \\
\hline 323453146 & 77879 & $\begin{array}{l}\text { Chloroplast light harvesting } \\
\text { protein }\end{array}$ & 5.333 & 10.667 & 5.667 & -0.490 & -0.085 & -0.130 & 0.941 & 1.882 \\
\hline 323448060 & 55398 & Ribosomal protein & 1.333 & 5.333 & 7.667 & 0.000 & -0.062 & -0.033 & 0.174 & 0.696 \\
\hline 323456741 & 35830 & $\begin{array}{l}\text { Mitochondrial substrate } \\
\text { carrier }\end{array}$ & 6.000 & 8.667 & 0.667 & 0.000 & 0.000 & -0.490 & 9.000 & 13.000 \\
\hline 323455317 & 20736 & Inorganic pyrophosphatase & 5.333 & 5.000 & 4.333 & -0.240 & -0.530 & -0.190 & 1.231 & 1.154 \\
\hline 323449640 & 30567 & Ribosomal protein & 1.000 & 5.333 & 6.333 & -0.001 & -0.190 & -0.014 & 0.158 & 0.842 \\
\hline 242620018 & & $\begin{array}{l}\text { photosystem I reaction center } \\
\text { subunit XI }\end{array}$ & 5.667 & 5.000 & 3.667 & -0.100 & -0.450 & -0.150 & 1.545 & 1.364 \\
\hline 323456110 & 20291 & Pyruvate carboxylase & 4.333 & 6.333 & 1.667 & -0.027 & -0.011 & -0.500 & 2.600 & 3.800 \\
\hline 323450214 & 60208 & Ribosomal protein & 2.000 & 6.667 & 5.333 & -0.050 & -0.520 & -0.034 & 0.375 & 1.250 \\
\hline 323450445 & 65714 & Co or Mg Chelatase & 4.000 & 7.333 & 1.667 & -0.042 & -0.003 & -0.260 & 2.400 & 4.400 \\
\hline 323455642 & 21301 & $5^{\prime}$-nucleotidase & 6.000 & 7.667 & 0.000 & 0.000 & 0.000 & -0.480 & $\mathrm{~N} / \mathrm{A}$ & N/A \\
\hline 323453007 & 70153 & Initiation factor & 2.333 & 7.000 & 3.333 & -0.410 & -0.097 & -0.045 & 0.700 & 2.100 \\
\hline 323448492 & 32656 & $\begin{array}{l}\text { Chloroplast photosystem II } 12 \\
\text { kDa extrinsic protein }\end{array}$ & 8.667 & 3.000 & 2.000 & 0.000 & -0.440 & 0.000 & 4.333 & 1.500 \\
\hline 323453325 & 71481 & $\begin{array}{l}\text { Phosphoenolpyruvate } \\
\text { carboxylase }\end{array}$ & 5.333 & 6.667 & 0.667 & 0.000 & 0.000 & -0.460 & 8.000 & 10.000 \\
\hline 323450330 & 72047 & ABC transporter & 7.000 & 6.333 & 0.000 & 0.000 & 0.000 & -0.130 & $\mathrm{~N} / \mathrm{A}$ & $\mathrm{N} / \mathrm{A}$ \\
\hline 323453338 & 53446 & Acetyl-coenzyme A synthetase & 4.667 & 5.667 & 2.000 & -0.032 & -0.047 & -0.440 & 2.333 & 2.833 \\
\hline 323450260 & 29608 & Inorganic pyrophosphatase & 4.667 & 6.000 & 2.000 & -0.032 & -0.033 & -0.500 & 2.333 & 3.000 \\
\hline 242620036 & & $60 \mathrm{kDa}$ chaperonin & 3.000 & 5.333 & 3.667 & -0.520 & -0.390 & -0.330 & 0.818 & 1.455 \\
\hline 323452746 & 60075 & Ribosomal protein & 1.000 & 5.000 & 6.333 & -0.001 & -0.150 & -0.021 & 0.158 & 0.789 \\
\hline 323456545 & 70049 & Ribosomal protein & 0.333 & 6.000 & 6.333 & 0.000 & -0.290 & 0.000 & 0.053 & 0.947 \\
\hline 323456061 & 20268 & Calcium transporting ATpase & 2.667 & 8.333 & 1.667 & -0.220 & -0.001 & -0.024 & 1.600 & 5.000 \\
\hline 323452301 & 37496 & Ribosomal protein & 1.667 & 5.000 & 5.667 & -0.018 & -0.240 & -0.087 & 0.294 & 0.882 \\
\hline 323451867 & 77983 & Selenoprotein & 2.000 & 4.667 & 6.667 & -0.011 & -0.081 & -0.190 & 0.300 & 0.700 \\
\hline 323455294 & 22099 & ABC transporter & 4.000 & 7.333 & 1.000 & -0.009 & 0.000 & -0.260 & 4.000 & 7.333 \\
\hline 323448025 & 60342 & Tubulin alpha- 2 chain & 3.667 & 7.667 & 1.000 & -0.016 & 0.000 & -0.160 & 3.667 & 7.667 \\
\hline 323456379 & 20552 & $\begin{array}{l}\text { Carbamoyl-phosphate } \\
\text { synthase }\end{array}$ & 3.333 & 6.667 & 0.333 & -0.003 & 0.000 & -0.210 & 10.000 & 20.000 \\
\hline 323452318 & 53660 & Myosin head, motor region & 3.000 & 9.333 & 0.000 & -0.001 & 0.000 & -0.018 & $\mathrm{~N} / \mathrm{A}$ & $\mathrm{N} / \mathrm{A}$ \\
\hline 323455059 & 58776 & $\begin{array}{l}\text { Dihydrolipoamide S- } \\
\text { acetyltransferase }\end{array}$ & 4.333 & 4.667 & 3.333 & -0.240 & -0.440 & -0.340 & 1.300 & 1.400 \\
\hline 323451115 & 6356 & $\begin{array}{l}\text { Manganese and iron } \\
\text { superoxide dismutase }\end{array}$ & 3.000 & 4.333 & 4.667 & -0.300 & -0.310 & -0.540 & 0.643 & 0.929 \\
\hline 323454557 & 23003 & Heat shock protein ( $\mathrm{Hsp} 70)$ & 4.667 & 5.333 & 3.000 & -0.130 & -0.230 & -0.380 & 1.556 & 1.778 \\
\hline 242620088 & & Rubisco expression protein & 4.333 & 5.000 & 2.333 & -0.080 & -0.140 & -0.400 & 1.857 & 2.143 \\
\hline 323447119 & 34507 & Ribosomal protein & 0.333 & 7.000 & 5.333 & 0.000 & -0.460 & 0.000 & 0.063 & 1.313 \\
\hline 323452337 & 71644 & Phosphate ABC transporter & 0.000 & 4.667 & 7.667 & 0.000 & -0.030 & 0.000 & 0.000 & 0.609 \\
\hline 323453613 & 58899 & $\begin{array}{l}\text { Chloroplast Ribose 5- } \\
\text { phosphate isomerase }\end{array}$ & 4.000 & 2.667 & 5.333 & -0.410 & -0.030 & -0.086 & 0.750 & 0.500 \\
\hline 323447711 & 72700 & Heat shock protein Hsp90 & 4.000 & 5.000 & 3.333 & -0.310 & .0 .370 & -0.490 & 1.200 & 1.500 \\
\hline 323454985 & 36612 & Histidinol dehydrogenase & 2.333 & 4.667 & 4.333 & -0.200 & -0.460 & -0.270 & 0.538 & 1.077 \\
\hline 323450867 & 37987 & Acetamidase/Formamidase & 2.000 & 4.000 & 5.667 & -0.035 & -0.110 & -0.300 & 0.353 & 0.706 \\
\hline 242620099 & & Cytochrome b6 & 5.000 & 3.667 & 2.333 & -0.036 & -0.380 & -0.083 & 2.143 & 1.571 \\
\hline 242620033 & & ATP synthase CF1 delta chain & 3.333 & 5.000 & 2.333 & -0.230 & -0.140 & -0.490 & 1.429 & 2.143 \\
\hline 323457045 & 52124 & $\begin{array}{l}\text { Cobalmin synthesis } \\
\text { protein/P47K like }\end{array}$ & 4.667 & 4.333 & 1.333 & -0.008 & -0.056 & -0.210 & 3.500 & 3.250 \\
\hline 323450976 & 28757 & Ribosomal protein & 1.000 & 5.000 & 4.667 & -0.013 & -0.450 & -0.021 & 0.214 & 1.071 \\
\hline 323451977 & 69812 & GDP-mannose 3,5-epimerase & 4.333 & 7.333 & 0.000 & 0.000 & 0.000 & -0.330 & $\mathrm{~N} / \mathrm{A}$ & N/A \\
\hline 242620108 & & $\begin{array}{l}\text { Photosystem I iron-sulfur } \\
\text { center subunit VII }\end{array}$ & 5.000 & 2.333 & 4.667 & -0.370 & -0.041 & -0.013 & 1.071 & 0.500 \\
\hline 323448756 & 55048 & RNA binding protein & 2.667 & 6.667 & 1.667 & -0.220 & -0.008 & -0.098 & 1.600 & 4.000 \\
\hline 323452597 & 37371 & $\begin{array}{l}\text { AMP-dependent synthetase } \\
\text { and ligase }\end{array}$ & 3.000 & 6.000 & 2.000 & -0.220 & -0.033 & -0.230 & 1.500 & 3.000 \\
\hline 323450333 & 59240 & $\begin{array}{l}\text { Isocitrate dehydrogenase } \\
\text { NADP-dependent }\end{array}$ & 7.000 & 3.000 & 1.333 & 0.000 & -0.220 & -0.002 & 5.250 & 2.250 \\
\hline 323452437 & 26536 & $\begin{array}{l}\text { Dihydrolipoamide } \\
\text { dehydrogenase }\end{array}$ & 3.000 & 4.333 & 3.667 & -0.520 & -0.560 & -0.540 & 0.818 & 1.182 \\
\hline 323455535 & 70921 & $\mathrm{ABC}$ transporter & 3.000 & 3.667 & 5.000 & -0.240 & -0.140 & -0.490 & 0.600 & 0.733 \\
\hline 323449224 & 31415 & Geranylgeranyl reductase & 2.000 & 5.000 & 2.667 & -0.490 & -0.210 & -0.150 & 0.750 & 1.875 \\
\hline 323446107 & 60394 & Ribosomal Protein & 2.000 & 4.667 & 4.667 & -0.098 & -0.380 & -0.190 & 0.429 & 1.000 \\
\hline 323452672 & 71555 & Hypothetical protein & 9.000 & 6.667 & 13.667 & -0.140 & 0.000 & -0.026 & 0.659 & 0.488 \\
\hline
\end{tabular}




\begin{tabular}{|c|c|c|c|c|c|c|c|c|c|c|}
\hline 323450747 & 7898 & Ribosomal Protein & 0.333 & 5.333 & 5.333 & 0.000 & -0.360 & -0.001 & 0.063 & 1.000 \\
\hline 323448256 & 60332 & Nitrate transporter & 0.333 & 9.000 & 1.333 & -0.230 & 0.000 & 0.000 & 0.250 & 6.750 \\
\hline 242620095 & & 30 S ribosomal protein $\mathrm{S} 4$ & 0.000 & 3.667 & 7.333 & 0.000 & -0.011 & -0.002 & 0.000 & 0.500 \\
\hline 323446616 & 68630 & $\begin{array}{l}\text { S-adenosylmethionine } \\
\text { synthetase }\end{array}$ & 2.333 & 4.667 & 3.667 & -0.330 & -0.530 & -0.270 & 0.636 & 1.273 \\
\hline 323448900 & 32040 & Transketolase & 3.667 & 3.000 & 3.000 & -0.310 & -0.440 & -0.180 & 1.222 & 1.000 \\
\hline 323455645 & 70952 & $\begin{array}{l}\text { Hypothetical protein, no } \\
\text { significant BLAST }\end{array}$ & 5.667 & 3.000 & 2.333 & -0.015 & -0.550 & -0.015 & 2.429 & 1.286 \\
\hline 323452673 & 63886 & Hypothetical protein & 11.333 & 8.000 & 16.333 & -0.170 & 0.000 & -0.009 & 0.694 & 0.490 \\
\hline 323454364 & 53011 & $\begin{array}{l}\text { Serine } \\
\text { hydroxymethyltransferase }\end{array}$ & 3.000 & 5.000 & 1.667 & -0.150 & -0.051 & -0.400 & 1.800 & 3.000 \\
\hline 323454110 & 8613 & Ribosomal protein & 1.333 & 4.667 & 5.000 & -0.019 & -0.310 & -0.065 & 0.267 & 0.933 \\
\hline 323453341 & 25486 & Tryptophan synthase & 3.000 & 3.667 & 2.333 & -0.310 & -0.380 & -0.490 & 1.286 & 1.571 \\
\hline 323454315 & 77808 & $\begin{array}{l}\text { Chloroplast light harvesting } \\
\text { protein }\end{array}$ & 4.333 & 4.000 & 1.333 & -0.013 & -0.080 & -0.220 & 3.250 & 3.000 \\
\hline 323448626 & 70385 & Elongation factor & 2.667 & 6.000 & 2.333 & -0.400 & -0.059 & -0.160 & 1.143 & 2.571 \\
\hline 323455519 & 52520 & Helicase & 3.667 & 6.000 & 0.667 & -0.006 & -0.001 & -0.390 & 5.500 & 9.000 \\
\hline 323449333 & 59391 & Ribosomal protein & 0.333 & 4.000 & 5.000 & -0.001 & -0.190 & -0.008 & 0.067 & 0.800 \\
\hline 323451781 & 71789 & Urea transporter & 0.000 & 5.333 & 5.000 & 0.000 & -0.440 & 0.000 & 0.000 & 1.067 \\
\hline 323456516 & 19845 & Enoyl-acyl carrier & 3.333 & 4.000 & 2.000 & -0.160 & -0.220 & -0.460 & 1.667 & 2.000 \\
\hline 323449254 & 38679 & $\begin{array}{l}\text { Carbamoyl-phosphate } \\
\text { synthase }\end{array}$ & 2.000 & 4.667 & 1.667 & -0.420 & -0.072 & -0.190 & 1.200 & 2.800 \\
\hline 323449672 & 77821 & $\begin{array}{l}\text { Chloroplast light harvesting } \\
\text { protein }\end{array}$ & 4.667 & 3.667 & 1.000 & -0.003 & -0.059 & -0.120 & 4.667 & 3.667 \\
\hline 323454820 & 59906 & $\begin{array}{l}\text { Chloroplast light harvesting } \\
\text { protein }\end{array}$ & 1.000 & 4.667 & 4.667 & -0.013 & -0.380 & -0.031 & 0.214 & 1.000 \\
\hline 323447110 & 70459 & Triosephosphate isomerase & 3.000 & 5.333 & 0.667 & -0.020 & -0.002 & -0.330 & 4.500 & 8.000 \\
\hline 323456607 & 19548 & Aminotransferase & 3.333 & 7.333 & 0.000 & -0.001 & 0.000 & -0.140 & $\mathrm{~N} / \mathrm{A}$ & $\mathrm{N} / \mathrm{A}$ \\
\hline 323448815 & 38929 & Ribosomal Protein & 0.000 & 3.333 & 7.000 & 0.000 & -0.010 & -0.004 & 0.000 & 0.476 \\
\hline 323452938 & 63826 & $\begin{array}{l}\text { Chloroplast inner membrane } \\
\text { protein }\end{array}$ & 2.667 & 4.000 & 2.667 & -0.500 & -0.400 & -0.510 & 1.000 & 1.500 \\
\hline 323448307 & 77917 & $\begin{array}{l}\text { Chloroplast light harvesting } \\
\text { protein }\end{array}$ & 2.667 & 4.333 & 3.000 & -0.590 & -0.420 & -0.440 & 0.889 & 1.444 \\
\hline 323451227 & 77837 & $\begin{array}{l}\text { Chloroplast light harvesting } \\
\text { protein }\end{array}$ & 2.333 & 4.333 & 3.333 & -0.410 & -0.510 & -0.330 & 0.700 & 1.300 \\
\hline 323456836 & 60700 & Hypothetical protein & 5.333 & 4.333 & 0.333 & 0.000 & -0.003 & -0.110 & 16.000 & 13.000 \\
\hline 323446872 & 34777 & Ribosomal Protein & 1.667 & 3.667 & 3.667 & -0.160 & -0.410 & -0.260 & 0.455 & 1.000 \\
\hline 323451587 & 28033 & Ribosomal Protein & 0.333 & 3.000 & 6.667 & 0.000 & -0.009 & -0.034 & 0.050 & 0.450 \\
\hline 323449278 & 38591 & Ribosomal Protein & 1.667 & 3.333 & 4.333 & -0.081 & -0.190 & -0.330 & 0.385 & 0.769 \\
\hline 323454417 & 71232 & Beta-ketoacyl ACP synthase & 4.000 & 4.000 & 1.000 & -0.009 & -0.040 & -0.290 & 4.000 & 4.000 \\
\hline 242620043 & & 50 S ribosomal protein L3 & 0.000 & 3.000 & 6.333 & 0.000 & -0.014 & -0.007 & 0.000 & 0.474 \\
\hline 323450235 & 29718 & Ttubulin beta chain & 3.000 & 5.333 & 0.000 & -0.001 & 0.000 & -0.330 & $\mathrm{~N} / \mathrm{A}$ & N/A \\
\hline 323447579 & 39329 & Ribosomal protein & 1.000 & 2.667 & 4.667 & -0.013 & -0.067 & -0.240 & 0.214 & 0.571 \\
\hline 323449835 & 54518 & $\begin{array}{l}\text { Chloroplast light harvesting } \\
\text { protein }\end{array}$ & 2.667 & 4.333 & 1.667 & -0.220 & -0.100 & -0.440 & 1.600 & 2.600 \\
\hline 323454677 & 71112 & $\begin{array}{l}\text { IspG protein, diphosphate } \\
\text { synthetase }\end{array}$ & 4.333 & 3.667 & 1.000 & -0.005 & -0.059 & -0.170 & 4.333 & 3.667 \\
\hline 323448097 & 55396 & $\begin{array}{l}\text { Chloroplast light harvesting } \\
\text { protein }\end{array}$ & 2.333 & 7.000 & 0.000 & -0.005 & 0.000 & -0.045 & $\mathrm{~N} / \mathrm{A}$ & N/A \\
\hline 323451404 & 64968 & $\begin{array}{l}\text { Tyrosinase, Phytanoyl-CoA } \\
\text { dioxygenase }\end{array}$ & 4.667 & 2.000 & 2.000 & -0.032 & -0.480 & -0.012 & 2.333 & 1.000 \\
\hline 323446694 & 34909 & Ribosomal protein & 1.000 & 3.333 & 3.667 & -0.048 & -0.330 & -0.130 & 0.273 & 0.909 \\
\hline 323455547 & 59886 & $\begin{array}{l}\text { Calreticulin precursor, } \\
\text { calnexin }\end{array}$ & 1.000 & 4.000 & 4.000 & -0.031 & -0.400 & -0.064 & 0.250 & 1.000 \\
\hline 323453645 & 24362 & $\begin{array}{l}\text { Phosphoribosylaminoimidazol } \\
\text { e carboxylase }\end{array}$ & 3.000 & 3.667 & 1.667 & -0.150 & -0.190 & -0.490 & 1.800 & 2.200 \\
\hline 323450079 & 59252 & Cysteine synthase & 1.667 & 2.333 & 4.667 & -0.057 & -0.041 & -0.600 & 0.357 & 0.500 \\
\hline 323447664 & 39321 & Protein kinase & 1.000 & 3.667 & 3.667 & -0.048 & -0.410 & -0.092 & 0.273 & 1.000 \\
\hline 323455675 & 77882 & $\begin{array}{l}\text { Chloroplast light harvesting } \\
\text { protein }\end{array}$ & 4.000 & 3.667 & 1.000 & -0.009 & -0.059 & -0.230 & 4.000 & 3.667 \\
\hline 323454033 & 58885 & Triosephosphate isomerase & 1.333 & 5.667 & 1.333 & -0.570 & -0.011 & -0.023 & 1.000 & 4.250 \\
\hline 323451116 & 28333 & Aliphatic amidase & 2.333 & 2.333 & 3.667 & -0.330 & -0.140 & -0.370 & 0.636 & 0.636 \\
\hline 323453409 & 24874 & Diaminopimelate epimerase & 4.667 & 1.667 & 1.000 & -0.003 & -0.470 & -0.006 & 4.667 & 1.667 \\
\hline 323450958 & 59175 & Peptidase & 2.333 & 3.667 & 0.333 & -0.023 & -0.008 & -0.480 & 7.000 & 11.000 \\
\hline 323453799 & 24373 & Pyruvate kinase & 6.667 & 1.667 & 0.333 & 0.000 & -0.160 & 0.000 & 20.000 & 5.000 \\
\hline 323453165 & 70159 & Ras GTPase & 3.000 & 3.000 & 1.333 & -0.090 & -0.220 & -0.330 & 2.250 & 2.250 \\
\hline
\end{tabular}




\begin{tabular}{|c|c|c|c|c|c|c|c|c|c|c|}
\hline 323451373 & 27934 & Ribosomal protein & 0.667 & 3.333 & 3.667 & -0.020 & -0.330 & $-0.06 \mid$ & 0.182 & 0.909 \\
\hline 323453682 & 71358 & Hypothetical protein & 0.333 & 1.000 & 4.000 & -0.003 & -0.007 & -0.440 & 0.083 & 0.250 \\
\hline 242620032 & & $\begin{array}{l}\text { ATP synthase CF0 B chain } \\
\text { subunit } 1\end{array}$ & 3.000 & 2.333 & 2.667 & -0.400 & -0.360 & -0.190 & 1.125 & 0.875 \\
\hline 323454382 & 71247 & $20 \mathrm{~S}$ proteasome & 1.667 & 1.667 & 2.667 & -0.370 & -0.190 & -0.430 & 0.625 & 0.625 \\
\hline 323448356 & 69968 & Ribosomal protein & 1.667 & 3.000 & 3.333 & -0.220 & -0.340 & -0.410 & 0.500 & 0.900 \\
\hline 323451802 & 64802 & Hypothetical protein & 2.667 & 3.333 & 2.000 & -0.310 & -0.350 & -0.520 & 1.333 & 1.667 \\
\hline 323450585 & 59202 & $\begin{array}{l}\text { Phosphoglycerate/bisphospho } \\
\text { glycerate mutase }\end{array}$ & 2.667 & 2.667 & 2.333 & -0.400 & -0.560 & -0.350 & 1.143 & 1.143 \\
\hline 323454249 & 23507 & $\begin{array}{l}\text { GDP-mannose 4,6- } \\
\text { dehydratase }\end{array}$ & 1.333 & 4.000 & 2.667 & -0.260 & -0.400 & -0.120 & 0.500 & 1.500 \\
\hline 323449374 & 66454 & Hypotheical protein & 1.667 & 3.000 & 2.333 & -0.470 & -0.550 & -0.410 & 0.714 & 1.286 \\
\hline 323456684 & 69589 & $\begin{array}{l}\text { 3-hydroxyacyl-CoA } \\
\text { dehydrogenase }\end{array}$ & 3.000 & 3.667 & 0.333 & -0.006 & -0.008 & -0.490 & 9.000 & 11.000 \\
\hline 323455682 & 69676 & Phosphoglucose isomerase & 3.667 & 3.000 & 0.333 & -0.002 & -0.022 & -0.180 & 11.000 & 9.000 \\
\hline 323455903 & 36266 & Ribosomal protein & 0.333 & 4.000 & 3.000 & -0.018 & -0.500 & -0.008 & 0.111 & 1.333 \\
\hline 323454360 & 58864 & Ribosomal protein & 0.333 & 2.667 & 3.333 & -0.010 & -0.260 & -0.054 & 0.100 & 0.800 \\
\hline 323453694 & 37118 & Glutamate synthase & 1.000 & 6.000 & 0.000 & -0.100 & 0.000 & -0.006 & $\mathrm{~N} / \mathrm{A}$ & $\mathrm{N} / \mathrm{A}$ \\
\hline 323450314 & 65882 & $\begin{array}{l}\text { Dimethymetaquinone } \\
\text { methyltransferase }\end{array}$ & 2.000 & 2.000 & 3.333 & -0.310 & -0.130 & -0.400 & 0.600 & 0.600 \\
\hline 323446737 & 34869 & Acyl carrier protein & 2.000 & 1.667 & 4.000 & -0.180 & -0.033 & -0.300 & 0.500 & 0.417 \\
\hline 323457240 & 18463 & Ammonium transporter & 1.000 & 2.333 & 4.000 & -0.031 & -0.093 & -0.330 & 0.250 & 0.583 \\
\hline 323454160 & 71132 & Peptidase & 1.333 & 4.333 & 2.000 & -0.460 & -0.160 & -0.090 & 0.667 & 2.167 \\
\hline 323446671 & 17075 & $\begin{array}{l}\text { Beta-hydroxyacyl-(acyl- } \\
\text { carrier-protein) dehydratase } \\
\text { FabZ }\end{array}$ & 1.000 & 3.000 & 3.000 & -0.110 & -0.440 & -0.180 & 0.333 & 1.000 \\
\hline 323454408 & 23206 & $\begin{array}{l}\text { Ferredoxin--NADP }(+) \\
\text { reductase }\end{array}$ & 22.333 & 24.667 & 20.667 & -0.140 & -0.520 & -0.120 & 1.081 & 1.194 \\
\hline 323452383 & 37542 & $\begin{array}{l}\text { Ribose-phosphate } \\
\text { pyrophosphokinase }\end{array}$ & 3.667 & 3.667 & 0.333 & -0.002 & -0.008 & -0.300 & 11.000 & 11.000 \\
\hline 323456630 & 60414 & $\begin{array}{l}\text { Heparan Sulfate } 2-0- \\
\text { sulfotranserase }\end{array}$ & 0.333 & 2.333 & 4.667 & -0.001 & -0.041 & -0.084 & 0.071 & 0.500 \\
\hline 323448438 & 72539 & RNA binding protein & 1.333 & 2.667 & 3.000 & -0.190 & -0.350 & -0.370 & 0.444 & 0.889 \\
\hline 323454510 & 71184 & \begin{tabular}{|l} 
Proteasome \\
\end{tabular} & 2.667 & 1.333 & 3.000 & -0.590 & -0.074 & -0.079 & 0.889 & 0.444 \\
\hline 323455949 & 52186 & Proteasome & 1.000 & 3.333 & 3.000 & -0.110 & -0.520 & -0.130 & 0.333 & 1.111 \\
\hline 323451767 & 27224 & $\begin{array}{l}\text { Hydroxyisobutyrate } \\
\text { dehydrogenase }\end{array}$ & 0.667 & 3.667 & 2.333 & -0.120 & -0.380 & -0.041 & 0.286 & 1.571 \\
\hline 323454706 & 23304 & $\begin{array}{l}\text { Ribonucleoprotein complex } \\
\text { subunit }\end{array}$ & 0.667 & 2.667 & 3.333 & -0.032 & -0.260 & -0.130 & 0.200 & 0.800 \\
\hline 323452898 & 25785 & Glutamate dehydrogenase & 3.000 & 3.333 & 0.333 & -0.006 & -0.013 & -0.410 & 9.000 & 10.000 \\
\hline 323455708 & 10538 & Cell division protein $\mathrm{FtsH}$ & 3.000 & 4.667 & 0.000 & -0.001 & 0.000 & -0.460 & $\mathrm{~N} / \mathrm{A}$ & $\mathrm{N} / \mathrm{A}$ \\
\hline 323451167 & 60165 & Ribosomal porotein & 0.000 & 1.333 & 4.333 & 0.000 & -0.009 & -0.110 & 0.000 & 0.308 \\
\hline 323457264 & 51957 & $\begin{array}{l}\text { Nicotinamide nucleotide } \\
\text { transhydrogenase }\end{array}$ & 3.667 & 3.333 & 0.000 & 0.000 & -0.002 & -0.240 & $\mathrm{~N} / \mathrm{A}$ & N/A \\
\hline 323454696 & 59930 & $\begin{array}{l}\text { Tetrahydrofolate } \\
\text { dehydrogenase/cyclohydrolase }\end{array}$ & 1.000 & 5.667 & 0.333 & -0.270 & 0.000 & -0.009 & 3.000 & 17.000 \\
\hline 323456719 & 60533 & Hypothetical protein & 3.000 & 2.333 & 1.333 & -0.090 & -0.390 & -0.190 & 2.250 & 1.750 \\
\hline 323449474 & 31056 & Semialdehyde dehydrogenase & 3.333 & 1.667 & 1.000 & -0.028 & -0.470 & -0.051 & 3.333 & 1.667 \\
\hline 323451071 & 71877 & Ribosomal protein & 0.333 & 3.333 & 3.333 & -0.010 & -0.420 & -0.021 & 0.100 & 1.000 \\
\hline 323450177 & 38219 & Ras small GTPase & 2.667 & 3.333 & 0.333 & -0.012 & -0.013 & -0.520 & 8.000 & 10.000 \\
\hline 323449160 & 69937 & Proteasome & 0.000 & 1.667 & 5.000 & 0.000 & -0.007 & -0.064 & 0.000 & 0.333 \\
\hline 323454354 & 53005 & Ormate nitrite transporter & 2.000 & 2.333 & 2.333 & -0.590 & -0.470 & -0.490 & 0.857 & 1.000 \\
\hline 323450131 & 30014 & $\begin{array}{l}\text { Xanthine/uracil/vitamin C } \\
\text { permease }\end{array}$ & 2.333 & 2.000 & 1.667 & -0.310 & -0.610 & -0.290 & 1.400 & 1.200 \\
\hline 323452963 & 25646 & Light inducinble protein & 2.333 & 2.333 & 1.333 & -0.210 & -0.390 & -0.370 & 1.750 & 1.750 \\
\hline 323446228 & 35224 & Ribosomal protein & 1.000 & 3.000 & 2.333 & -0.230 & -0.550 & -0.180 & 0.429 & 1.286 \\
\hline 323449422 & 72267 & Luteovirus ORF6 protein & 1.333 & 1.333 & 3.333 & -0.130 & -0.046 & -0.460 & 0.400 & 0.400 \\
\hline 323455449 & 59875 & Ribosomal protein & 1.000 & 2.667 & 2.667 & -0.160 & -0.450 & -0.240 & 0.375 & 1.000 \\
\hline 323451852 & 77830 & $\begin{array}{l}\text { Chloroplast light harvesting } \\
\text { protein }\end{array}$ & 1.333 & 3.000 & 2.000 & -0.460 & -0.440 & -0.290 & 0.667 & 1.500 \\
\hline 323451675 & 71753 & Hypothetical protein & 2.000 & 2.333 & 1.667 & -0.420 & -0.520 & -0.490 & 1.200 & 1.400 \\
\hline 323452748 & 25684 & $\begin{array}{l}\text { TB2/DP1/HVA22 related } \\
\text { protein }\end{array}$ & 3.000 & 2.000 & 1.000 & -0.047 & -0.350 & -0.130 & 3.000 & 2.000 \\
\hline 323452124 & 16956 & Cytochrome & 1.000 & 1.667 & 4.000 & -0.031 & -0.033 & -0.540 & 0.250 & 0.417 \\
\hline 323449261 & 66559 & Ribosomal protein & 0.000 & 4.000 & 2.333 & -0.012 & -0.300 & -0.001 & 0.000 & 1.714 \\
\hline
\end{tabular}




\begin{tabular}{|c|c|c|c|c|c|c|c|c|c|c|}
\hline 323453524 & 69744 & Glutathion transferase & 2.333 & 3.667 & 0.000 & -0.005 & -0.001 & -0.480 & $\mathrm{~N} / \mathrm{A}$ & $\mathrm{N} / \mathrm{A}$ \\
\hline 323454682 & 71109 & GDP dissociation protein & 2.333 & 3.000 & 0.000 & -0.005 & -0.004 & -0.550 & $\mathrm{~N} / \mathrm{A}$ & N/A \\
\hline 323453260 & 4272 & $\begin{array}{l}\text { Phosphoadenosine } \\
\text { phosphosulfate reductase }\end{array}$ & 1.667 & 2.000 & 2.000 & -0.580 & -0.480 & -0.530 & 0.833 & 1.000 \\
\hline 323455961 & 59805 & $\begin{array}{l}\text { Chloroplast light harvesting } \\
\text { protein }\end{array}$ & 2.333 & 2.333 & 1.667 & -0.310 & -0.520 & -0.370 & 1.400 & 1.400 \\
\hline 323450829 & 71930 & Ras small GTPase & 1.000 & 2.667 & 1.333 & -0.570 & -0.290 & -0.240 & 0.750 & 2.000 \\
\hline 323457083 & 58588 & Magnesium chelatase & 2.667 & 2.000 & 1.667 & -0.220 & -0.610 & -0.200 & 1.600 & 1.200 \\
\hline 323453963 & 77823 & $\begin{array}{l}\text { Chloroplast light harvesting } \\
\text { protein }\end{array}$ & 2.000 & 2.333 & 1.667 & -0.420 & -0.520 & -0.490 & 1.200 & 1.400 \\
\hline 323452943 & 60062 & Ribosomal protein & 0.667 & 3.000 & 2.667 & -0.080 & -0.540 & -0.091 & 0.250 & 1.125 \\
\hline 323455143 & 22183 & Ribosomal protein & 0.667 & 2.000 & 3.000 & -0.051 & -0.190 & -0.270 & 0.222 & 0.667 \\
\hline 323449038 & 38757 & Peptidase & 0.333 & 2.667 & 3.333 & -0.010 & -0.260 & -0.054 & 0.100 & 0.800 \\
\hline 242620045 & & $50 \mathrm{~S}$ ribosomal protein $\mathrm{L} 2$ & 0.000 & 3.333 & 3.000 & -0.003 & -0.520 & -0.004 & 0.000 & 1.111 \\
\hline 242620089 & & $\begin{array}{l}\text { Conserved hypothetical plastid } \\
\text { protein Ycf39 }\end{array}$ & 2.000 & 3.667 & 0.333 & -0.044 & -0.008 & -0.370 & 6.000 & 11.000 \\
\hline 323452812 & 25795 & $\begin{array}{l}\text { Dihydrolipoamide } \\
\text { dehydrogenase }\end{array}$ & 0.000 & 1.000 & 5.000 & 0.000 & -0.001 & -0.190 & 0.000 & 0.200 \\
\hline 323452243 & 64345 & $\begin{array}{l}\text { Glycinamide ribonucleotide } \\
\text { synthetase-aminoimidazole } \\
\text { ribonucleotide synthetase- } \\
\text { glycinamide ribonucleotide } \\
\text { transformylase }\end{array}$ & 1.000 & 2.000 & 2.333 & -0.230 & -0.370 & -0.420 & 0.429 & 0.857 \\
\hline 323448587 & 38989 & Adenylosuccinate synthetase & 1.000 & 2.333 & 2.667 & -0.160 & -0.360 & -0.330 & 0.375 & 0.875 \\
\hline 323456068 & 52275 & Heat shock protein & 1.000 & 2.333 & 1.667 & -0.430 & -0.520 & -0.330 & 0.600 & 1.400 \\
\hline 323451686 & 59069 & $\begin{array}{l}\text { Chloroplast light harvesting } \\
\text { protein }\end{array}$ & 2.333 & 1.667 & 1.667 & -0.310 & -0.510 & -0.200 & 1.400 & 1.000 \\
\hline 323451892 & 53834 & $\mathrm{H}+$-transporting ATPase & 0.667 & 2.000 & 2.667 & -0.080 & -0.270 & -0.270 & 0.250 & 0.750 \\
\hline 323448447 & 32730 & Endopeptidase Clp activity & 2.000 & 2.000 & 2.000 & -0.530 & -0.480 & -0.400 & 1.000 & 1.000 \\
\hline 323454156 & 23622 & Myo-inositol 2-dehdrogenase & 0.667 & 3.000 & 1.333 & -0.400 & -0.220 & -0.091 & 0.500 & 2.250 \\
\hline 323452393 & 64290 & $\begin{array}{l}\text { OmpA } / \text { MotB domain- } \\
\text { containing protein }\end{array}$ & 3.333 & 1.667 & 0.333 & -0.003 & -0.160 & -0.051 & 10.000 & 5.000 \\
\hline 323447335 & 77912 & Formate/nitrite transporter & 2.000 & 2.667 & 0.000 & -0.011 & -0.008 & -0.590 & $\mathrm{~N} / \mathrm{A}$ & $\mathrm{N} / \mathrm{A}$ \\
\hline 323450320 & 60213 & Ribosomal protein & 0.000 & 3.000 & 3.000 & -0.003 & -0.440 & -0.007 & 0.000 & 1.000 \\
\hline 242620044 & & 50 S ribosomal protein L23 & 0.000 & 1.667 & 3.667 & -0.001 & -0.052 & -0.064 & 0.000 & 0.455 \\
\hline 323449109 & 69941 & $\begin{array}{l}\text { Low molecular weight } \\
\text { phosphotyrosine protein } \\
\text { phosphatase }\end{array}$ & 2.000 & 3.667 & 0.000 & -0.011 & -0.001 & -0.370 & $\mathrm{~N} / \mathrm{A}$ & $N / A$ \\
\hline 323452273 & 64100 & Hypotheical protein & 3.000 & 3.000 & 0.000 & -0.001 & -0.004 & -0.330 & $\mathrm{~N} / \mathrm{A}$ & $\mathrm{N} / \mathrm{A}$ \\
\hline 323450582 & 65618 & Transketolase & 2.333 & 3.000 & 0.000 & -0.005 & -0.004 & -0.550 & N/A & $\mathrm{N} / \mathrm{A}$ \\
\hline 323451061 & 71871 & Histidine kinase & 1.667 & 3.000 & 0.000 & -0.023 & -0.004 & -0.410 & $\mathrm{~N} / \mathrm{A}$ & N/A \\
\hline 323450099 & 54387 & $\begin{array}{l}\text { Proteasome } \\
\end{array}$ & 1.000 & 2.667 & 2.000 & -0.320 & -0.530 & -0.240 & 0.500 & 1.333 \\
\hline 323453003 & 37193 & Vesicle coat complex & 1.667 & 2.333 & 1.667 & -0.540 & -0.520 & -0.600 & 1.000 & 1.400 \\
\hline 323454002 & 15386 & $\begin{array}{l}\text { Peptidyl-prolyl cis-trans } \\
\text { isomerase }\end{array}$ & 1.667 & 3.000 & 0.667 & -0.180 & -0.062 & -0.410 & 2.500 & 4.500 \\
\hline 323453823 & 71380 & Brix domain & 2.333 & 2.000 & 1.000 & -0.130 & -0.350 & -0.290 & 2.333 & 2.000 \\
\hline 323453684 & 37110 & $\begin{array}{l}\text { H+-transporting two-sector } \\
\text { ATPase }\end{array}$ & 1.667 & 3.333 & 0.667 & -0.180 & -0.040 & -0.330 & 2.500 & 5.000 \\
\hline 323455795 & 70840 & Hypotheical protein & 1.333 & 1.000 & 3.000 & -0.190 & -0.038 & -0.340 & 0.444 & 0.333 \\
\hline 323449806 & 30491 & $\begin{array}{l}\text { Phytoene dehydrogenase- } \\
\text { related protein }\end{array}$ & 1.000 & 2.667 & 0.667 & -0.440 & -0.095 & -0.240 & 1.500 & 4.000 \\
\hline 323448789 & 55095 & GUN4 like domain & 2.333 & 2.667 & 0.333 & -0.023 & -0.036 & -0.460 & 7.000 & 8.000 \\
\hline 323453085 & 71458 & Calcium-binding EF-hand & 1.000 & 3.667 & 1.000 & -0.600 & -0.059 & -0.092 & 1.000 & 3.667 \\
\hline 323455637 & 58713 & $\begin{array}{l}\text { RAN finction family member } \\
\text { supported with BLASTp }\end{array}$ & 1.333 & 3.000 & 0.333 & -0.150 & -0.022 & -0.290 & 4.000 & 9.000 \\
\hline 323454406 & 59975 & Armet super family domain & 0.333 & 1.667 & 2.667 & -0.030 & -0.190 & -0.200 & 0.125 & 0.625 \\
\hline 242620051 & & 50 S ribosomal protein $\mathrm{L} 14$ & 0.333 & 2.000 & 3.333 & -0.010 & -0.130 & -0.130 & 0.100 & 0.600 \\
\hline 323448823 & 72468 & Adenylylsulfate kinase & 1.667 & 2.667 & 0.000 & -0.023 & -0.008 & -0.510 & N/A & $\mathrm{N} / \mathrm{A}$ \\
\hline 323454381 & 23365 & Cystathione gamma lyase & 0.000 & 3.000 & 2.000 & -0.022 & -0.440 & -0.007 & 0.000 & 1.500 \\
\hline 323451378 & 59110 & Sterol methyltransferase & 2.333 & 2.667 & 0.000 & -0.005 & -0.008 & -0.460 & $\mathrm{~N} / \mathrm{A}$ & $\mathrm{N} / \mathrm{A}$ \\
\hline 323453289 & 71496 & $\begin{array}{l}\text { BLASTp putative protein with } \\
\text { GPS domain }\end{array}$ & 0.667 & 3.333 & 1.333 & -0.400 & -0.160 & -0.061 & 0.500 & 2.500 \\
\hline 323450531 & 29439 & Calcium ATPase & 1.333 & 2.000 & 1.333 & -0.570 & -0.490 & -0.570 & 1.000 & 1.500 \\
\hline 323449845 & 72180 & Hypothetical protein & 1.667 & 2.000 & 0.667 & -0.180 & -0.210 & -0.530 & 2.500 & 3.000 \\
\hline 323450569 & 54227 & Ribosomal protein & 0.000 & 1.667 & 3.000 & -0.003 & -0.130 & -0.064 & 0.000 & 0.556 \\
\hline 323452077 & 17528 & Ribosomal protein & 0.333 & 2.667 & 2.333 & -0.05 I & -0.560 & -0.054 & 0.143 & 1.143 \\
\hline
\end{tabular}




\begin{tabular}{|c|c|c|c|c|c|c|c|c|c|c|}
\hline 323453164 & 53460 & $\begin{array}{l}\text { N-ethylmaleimide sensitive } \\
\text { fusion protein } \\
\end{array}$ & 1.667 & 3.333 & 0.000 & -0.023 & -0.002 & -0.330 & $\mathrm{~N} / \mathrm{A}$ & $\mathrm{N} / \mathrm{A}$ \\
\hline 323452089 & 53803 & $\begin{array}{l}\text { IMP dehydrogenase/GMP } \\
\text { reductase }\end{array}$ & 0.000 & 1.667 & 3.000 & -0.003 & -0.130 & -0.064 & 0.000 & 0.556 \\
\hline 323454388 & 23619 & Splicing factor & 0.333 & 3.333 & 1.000 & -0.360 & -0.088 & -0.021 & 0.333 & 3.333 \\
\hline 323452833 & 37435 & CAP protein & 2.333 & 2.667 & 0.000 & -0.005 & -0.008 & -0.460 & $\mathrm{~N} / \mathrm{A}$ & $\mathrm{N} / \mathrm{A}$ \\
\hline 323447982 & 33371 & $\begin{array}{l}\text { Peptidyl-prolyl cis-trans } \\
\text { isomerase }\end{array}$ & 0.667 & 4.333 & 0.333 & -0.450 & -0.003 & -0.018 & 2.000 & 13.000 \\
\hline 323456174 & 61355 & Translational activator & 0.667 & 3.000 & 0.333 & -0.450 & -0.022 & -0.091 & 2.000 & 9.000 \\
\hline 323454181 & 12877 & $\begin{array}{l}\text { Zinc-containing alcohol } \\
\text { dehydrogenase superfamily }\end{array}$ & 1.333 & 3.000 & 0.000 & -0.048 & -0.004 & -0.290 & $\mathrm{~N} / \mathrm{A}$ & $\mathrm{N} / \mathrm{A}$ \\
\hline 323456017 & 59818 & CTP synthase & 1.000 & 1.667 & 1.000 & -0.600 & -0.470 & -0.540 & 1.000 & 1.667 \\
\hline 323452600 & 77873 & $\begin{array}{l}\text { Inorganic phosphate } \\
\text { transporter }\end{array}$ & 1.333 & 1.667 & 0.333 & -0.150 & -0.160 & -0.580 & 4.000 & 5.000 \\
\hline 323446721 & 39490 & $\begin{array}{l}\text { Coproporphyrinogen III } \\
\text { oxidase }\end{array}$ & 0.667 & 2.000 & 1.667 & -0.280 & -0.610 & -0.270 & 0.400 & 1.200 \\
\hline 323447291 & 34298 & Phosphoglycerate mutase & 2.000 & 1.333 & 0.667 & -0.110 & -0.430 & -0.210 & 3.000 & 2.000 \\
\hline 323447671 & 72706 & Ribosomal protein & 0.667 & 2.000 & 2.333 & -0.120 & -0.370 & -0.270 & 0.286 & 0.857 \\
\hline 323450970 & 28783 & Ribosomal protein & 0.333 & 2.000 & 2.667 & -0.030 & -0.270 & -0.130 & 0.125 & 0.750 \\
\hline 323455165 & 21835 & Inorganic pyrophosphatase & 1.667 & 1.667 & 0.333 & -0.083 & -0.160 & -0.430 & 5.000 & 5.000 \\
\hline 323452927 & 71545 & Asparagine synthase & 0.667 & 3.000 & 1.000 & -0.560 & -0.130 & -0.091 & 0.667 & 3.000 \\
\hline 323449776 & 77854 & Urease & 1.333 & 0.333 & 2.333 & -0.350 & -0.019 & -0.110 & 0.571 & 0.143 \\
\hline 323451387 & 28095 & $\begin{array}{l}20 \mathrm{~S} \text { proteasome, } \mathrm{A} \text { and } \mathrm{B} \\
\text { subunits }\end{array}$ & 0.333 & 1.333 & 3.333 & -0.010 & -0.046 & -0.300 & 0.100 & 0.400 \\
\hline 323452801 & 64057 & Hypothetical protein & 1.000 & 1.000 & 0.333 & -0.270 & -0.380 & -0.500 & 3.000 & 3.000 \\
\hline 323453239 & 70163 & $\begin{array}{l}\text { Proliferating cell nuclear } \\
\text { antigen, PCNA }\end{array}$ & 0.000 & 2.000 & 2.333 & -0.012 & -0.370 & -0.037 & 0.000 & 0.857 \\
\hline 242620066 & & $30 \mathrm{~S}$ ribosomal protein S7 & 0.000 & 2.333 & 2.333 & -0.012 & -0.470 & -0.021 & 0.000 & 1.000 \\
\hline 323452338 & 37524 & $\begin{array}{l}\text { Helicase and restriction } \\
\text { enzyme domain }\end{array}$ & 0.000 & 2.333 & 1.667 & -0.042 & -0.520 & -0.021 & 0.000 & 1.400 \\
\hline 323455998 & 70668 & Alkaline phosphatase & 4.333 & 0.667 & 0.000 & 0.000 & -0.300 & -0.001 & $\mathrm{~N} / \mathrm{A}$ & $\mathrm{N} / \mathrm{A}$ \\
\hline 323447466 & 72743 & Acting binding $\mathrm{FH} 2$ & 1.667 & 1.333 & 1.667 & -0.540 & -0.390 & -0.320 & 1.000 & 0.800 \\
\hline 323452857 & 25558 & Glutathione reductase & 0.667 & 2.000 & 1.667 & -0.280 & -0.610 & -0.270 & 0.400 & 1.200 \\
\hline 323452157 & 59049 & Ribosomal protein & 0.667 & 1.000 & 2.000 & -0.190 & -0.170 & -0.640 & 0.333 & 0.500 \\
\hline 323452499 & 26373 & Homoserine dehydrogenase & 1.000 & 1.667 & 2.000 & -0.320 & -0.380 & -0.540 & 0.500 & 0.833 \\
\hline 323448899 & 31937 & Deliydrogenase & 1.000 & 2.333 & 0.667 & -0.440 & -0.140 & -0.330 & 1.500 & 3.500 \\
\hline 323455705 & 20758 & $\begin{array}{l}\begin{array}{l}\text { Serine } \\
\text { hydroxymethyltransferase }\end{array} \\
\end{array}$ & 1.000 & 2.333 & 0.667 & -0.440 & -0.140 & -0.330 & 1.500 & 3.500 \\
\hline 323457101 & 59786 & Chaperonin & 1.000 & 2.000 & 0.667 & -0.440 & -0.210 & -0.420 & 1.500 & 3.000 \\
\hline 323456188 & 19929 & Heat shock protein & 0.667 & 2.333 & 0.667 & -0.640 & -0.140 & -0.190 & 1.000 & 3.500 \\
\hline 323454770 & 1561 & Calreticulin/calnexin & 2.000 & 2.667 & 0.333 & -0.044 & -0.036 & -0.590 & 6.000 & 8.000 \\
\hline 323456208 & 36201 & \begin{tabular}{|l} 
Synaptobrevin \\
\end{tabular} & 2.333 & 2.000 & 0.000 & -0.005 & -0.026 & -0.290 & $\mathrm{~N} / \mathrm{A}$ & $\mathrm{N} / \mathrm{A}$ \\
\hline 323452787 & 17219 & Ribosomal protein & 0.000 & 1.667 & 2.333 & -0.012 & -0.270 & -0.064 & 0.000 & 0.714 \\
\hline 323449760 & 59319 & Glycine cleavage system & 1.000 & 3.000 & 0.333 & -0.270 & -0.022 & -0.180 & 3.000 & 9.000 \\
\hline 323452846 & 26092 & Argininosuccinate synthase & 1.333 & 2.333 & 0.667 & -0.290 & -0.140 & -0.470 & 2.000 & 3.500 \\
\hline 323453590 & 63073 & ATPase & 1.667 & 3.000 & 0.000 & -0.023 & -0.004 & -0.410 & $\mathrm{~N} / \mathrm{A}$ & N/A \\
\hline 323446732 & 68563 & Hypothetical protein & 2.333 & 2.000 & 0.000 & -0.005 & -0.026 & -0.290 & $\mathrm{~N} / \mathrm{A}$ & $\mathrm{N} / \mathrm{A}$ \\
\hline 323449711 & 59335 & Heat shock protein & 0.000 & 2.333 & 1.333 & -0.080 & -0.390 & -0.021 & 0.000 & 1.750 \\
\hline 323449583 & 54676 & Ribosomal protein & 0.333 & 1.000 & 3.333 & -0.010 & -0.022 & -0.440 & 0.100 & 0.300 \\
\hline 323455948 & 70645 & $\begin{array}{l}\text { Mucin-associated surface } \\
\text { protein (MASP) }\end{array}$ & 0.667 & 0.000 & 3.333 & -0.032 & 0.000 & -0.180 & 0.200 & 0.000 \\
\hline 323455062 & 59926 & Cytochrome $\mathrm{C}$ & 2.000 & 1.000 & 1.000 & -0.200 & -0.570 & -0.130 & 2.000 & 1.000 \\
\hline 323450323 & 29703 & Threonyl-tRNA synthetase & 1.000 & 2.000 & 0.667 & -0.440 & -0.210 & -0.420 & 1.500 & 3.000 \\
\hline 323446946 & 68429 & Hypothetical protein & 1.333 & 1.667 & 3.667 & -0.094 & -0.052 & -0.580 & 0.364 & 0.455 \\
\hline 323455402 & 21676 & Protease & 1.000 & 2.000 & 1.000 & -0.600 & -0.350 & -0.420 & 1.000 & 2.000 \\
\hline 323456496 & 20345 & $\begin{array}{l}\text { AICARFT/IMPCHase } \\
\text { bienzyme, Methylglyoxal } \\
\text { synthase-like }\end{array}$ & 1.000 & 2.000 & 0.667 & -0.440 & -0.210 & -0.420 & 1.500 & 3.000 \\
\hline 242620056 & & $30 \mathrm{~S}$ ribosomal protein S5 & 0.333 & 2.000 & 2.000 & -0.086 & -0.480 & -0.130 & 0.167 & 1.000 \\
\hline 323450650 & 65557 & $\begin{array}{l}\text { Phosphate } \mathrm{ABC} \text { transporter } \\
\text { permease }\end{array}$ & 1.667 & 0.333 & 2.000 & -0.580 & -0.037 & -0.053 & 0.833 & 0.167 \\
\hline 323454389 & 22992 & Translation initiaion factor & 0.333 & 1.333 & 1.667 & -0.140 & -0.390 & -0.300 & 0.200 & 0.800 \\
\hline 323448266 & 33048 & Histone & 12.667 & 36.667 & 41.667 & -0.460 & -0.010 & -0.018 & 0.304 & 0.880 \\
\hline 323455110 & 12414 & $\begin{array}{l}\text { Uroporphyrinogen } \\
\text { decarboxylase (URO-D) }\end{array}$ & 2.000 & 1.333 & 0.667 & -0.110 & -0.430 & -0.210 & 3.000 & 2.000 \\
\hline 323455057 & 22578 & Threonine synthase & 1.000 & 2.333 & 0.667 & -0.440 & -0.140 & -0.330 & 1.500 & 3.500 \\
\hline
\end{tabular}




\begin{tabular}{|c|c|c|c|c|c|c|c|c|c|c|}
\hline 323451149 & 60167 & $\begin{array}{l}20 \mathrm{~S} \text { proteasome, } \mathrm{A} \text { and } \mathrm{B} \\
\text { subunits }\end{array}$ & 0.667 & 0.333 & 2.333 & -0.120 & -0.019 & -0.390 & 0.286 & 0.143 \\
\hline 323446359 & 68778 & $\begin{array}{l}\text { Patched, Sterol-sensing 5TM } \\
\text { box }\end{array}$ & 1.667 & 1.333 & 0.667 & -0.180 & -0.430 & -0.320 & 2.500 & 2.000 \\
\hline 323456109 & 10168 & ATPase & 2.000 & 2.000 & 0.000 & -0.011 & -0.026 & -0.400 & $\mathrm{~N} / \mathrm{A}$ & $\mathrm{N} / \mathrm{A}$ \\
\hline 323453433 & 53391 & Nitrate reducatase & 0.000 & 4.000 & 0.333 & -0.530 & -0.005 & -0.001 & 0.000 & 12.000 \\
\hline 323451357 & 69836 & Rab family GTPase & 2.000 & 1.333 & 0.333 & -0.044 & -0.250 & -0.210 & 6.000 & 4.000 \\
\hline 323456121 & 70709 & Actin like protein & 1.333 & 2.000 & 0.333 & -0.150 & -0.098 & -0.570 & 4.000 & 6.000 \\
\hline 242620053 & & $50 \mathrm{~S}$ ribosomal protein $\mathrm{L} 5$ & 0.000 & 2.333 & 1.000 & -0.150 & -0.260 & -0.021 & 0.000 & 2.333 \\
\hline 242620100 & & $30 \mathrm{~S}$ ribosomal protein $\mathrm{S} 6$ & 0.333 & 2.000 & 1.667 & -0.140 & -0.610 & -0.130 & 0.200 & 1.200 \\
\hline 323453700 & 60020 & Elongation factor & 0.333 & 2.000 & 1.333 & -0.230 & -0.490 & -0.130 & 0.250 & 1.500 \\
\hline 323448915 & 32029 & Beta ketoacyl ACP synthase & 0.333 & 2.000 & 1.333 & -0.230 & -0.490 & -0.130 & 0.250 & 1.500 \\
\hline 323450977 & 71923 & $\begin{array}{l}\text { Tubulin, Cell division protein } \\
\text { FtsZ }\end{array}$ & 1.333 & 2.333 & 0.333 & -0.150 & -0.060 & -0.470 & 4.000 & 7.000 \\
\hline 323453278 & 37323 & Oxoglutarate dehydrogenase & 1.667 & 1.667 & 0.333 & -0.083 & -0.160 & -0.430 & 5.000 & 5.000 \\
\hline 323455128 & 59919 & Hypothetical protein & 0.333 & 1.667 & 2.000 & -0.086 & -0.380 & -0.200 & 0.167 & 0.833 \\
\hline 323455320 & 70771 & Amine oxidase & 0.667 & 1.000 & 1.333 & -0.400 & -0.400 & -0.640 & 0.500 & 0.750 \\
\hline 323451608 & 27981 & Ribosomal Protein & 0.000 & 1.667 & 1.333 & -0.080 & -0.610 & -0.064 & 0.000 & 1.250 \\
\hline 323455983 & 61076 & $\begin{array}{l}\text { Flavin containing } \\
\text { monooxygenase } 5\end{array}$ & 1.333 & 1.000 & 0.000 & -0.048 & -0.160 & -0.340 & $\mathrm{~N} / \mathrm{A}$ & $\mathrm{N} / \mathrm{A}$ \\
\hline 323450621 & 29090 & Ribosomal protein & 0.000 & 1.667 & 1.667 & -0.042 & -0.510 & -0.064 & 0.000 & 1.000 \\
\hline 323454199 & 59942 & DnaJ homolog & 0.667 & 1.667 & 0.667 & -0.640 & -0.310 & -0.370 & 1.000 & 2.500 \\
\hline 323450083 & 60218 & Ribosomal protein & 0.000 & 1.333 & 1.667 & -0.042 & -0.390 & -0.110 & 0.000 & 0.800 \\
\hline 323452263 & 69799 & Peptidase / Proteasome & 0.333 & 1.000 & 2.000 & -0.086 & -0.170 & -0.440 & 0.167 & 0.500 \\
\hline 323456325 & 52346 & Phosphatase & 0.000 & 2.000 & 2.000 & -0.022 & -0.480 & -0.037 & 0.000 & 1.000 \\
\hline 323450948 & 28673 & $\begin{array}{l}\text { Succinyl-CoA synthetase, ATP } \\
\text { citrate lyase/succinyl-CoA } \\
\text { ligase. Succinyl-CoA } \\
\text { synthetase. ATP-citrate } \\
\text { lyase/succinyl-CoA ligase }\end{array}$ & 0.667 & 0.667 & 1.667 & -0.280 & -0.160 & -0.560 & 0.400 & 0.400 \\
\hline 323450133 & 38247 & Heat shock protein & 1.000 & 2.000 & 0.667 & -0.440 & -0.210 & -0.420 & 1.500 & 3.000 \\
\hline 323449973 & 60228 & Proteasome & 0.000 & 1.333 & 1.667 & -0.042 & -0.390 & -0.110 & 0.000 & 0.800 \\
\hline 323451260 & 69850 & Cobalamin synthesis protein & 2.000 & 1.667 & 0.000 & -0.011 & -0.048 & -0.300 & $\mathrm{~N} / \mathrm{A}$ & $\mathrm{N} / \mathrm{A}$ \\
\hline 323451909 & 27356 & $\begin{array}{l}\text { ATP } \\
\text { phosphoribosyltransferase }\end{array}$ & 0.333 & 2.000 & 1.667 & -0.140 & -0.610 & -0.130 & 0.200 & 1.200 \\
\hline 323450497 & 72023 & $\begin{array}{l}\text { Serine/threonine-protein } \\
\text { phosphatase }\end{array}$ & 1.000 & 1.667 & 0.000 & -0.100 & -0.048 & -0.540 & $\mathrm{~N} / \mathrm{A}$ & N/A \\
\hline 323452306 & 26433 & RNA binding protein & 0.333 & 1.333 & 1.000 & -0.360 & -0.600 & -0.300 & 0.333 & 1.333 \\
\hline 323448914 & 60302 & Malate dehydrogenase & 0.667 & 3.000 & 0.000 & -0.220 & -0.004 & -0.091 & $\mathrm{~N} / \mathrm{A}$ & $\mathrm{N} / \mathrm{A}$ \\
\hline 323451863 & 27395 & $\begin{array}{l}\text { Aspartate/other } \\
\text { aminotransferase }\end{array}$ & 0.667 & 3.000 & 0.000 & -0.220 & -0.004 & -0.091 & $\mathrm{~N} / \mathrm{A}$ & N/A \\
\hline 323451862 & 27202 & $\begin{array}{l}\mathrm{H}+\text {-transporting two-sector } \\
\text { ATPase }\end{array}$ & 1.000 & 1.667 & 1.000 & -0.600 & -0.470 & -0.540 & 1.000 & 1.667 \\
\hline 323457289 & 59757 & $\begin{array}{l}\text { Eukaryotic initiation factor } 5 \mathrm{~A} \\
\text { hypusine }\end{array}$ & 1.000 & 1.667 & 0.667 & -0.440 & -0.310 & -0.540 & 1.500 & 2.500 \\
\hline 323448128 & 7478 & $\begin{array}{l}\text { Peptidyl-prolyl cis-trans } \\
\text { isomerase }\end{array}$ & 1.333 & 1.000 & 0.667 & -0.290 & -0.590 & -0.340 & 2.000 & 1.500 \\
\hline 323447945 & 72648 & Phosphofructokinase & 0.667 & 2.000 & 0.667 & -0.640 & -0.210 & -0.270 & 1.000 & 3.000 \\
\hline 323449674 & 69917 & Peptidase & 0.000 & 2.000 & 1.000 & -0.150 & -0.350 & -0.037 & 0.000 & 2.000 \\
\hline 323457341 & 70480 & $\begin{array}{l}\text { Contains pleckstrin-like } \\
\text { domain }\end{array}$ & 1.333 & 2.000 & 0.333 & -0.150 & -0.098 & -0.570 & 4.000 & 6.000 \\
\hline 323454473 & 23252 & $\begin{array}{l}\text { Iron-dependent fumarate } \\
\text { hydratase, Fe-S type hydro- } \\
\text { lyases tartrate/fumarate }\end{array}$ & 1.333 & 1.667 & 0.000 & -0.048 & -0.048 & -0.580 & $\mathrm{~N} / \mathrm{A}$ & $\mathrm{N} / \mathrm{A}$ \\
\hline 323449899 & 60237 & Ribosomal protein & 0.000 & 1.667 & 2.000 & -0.022 & -0.380 & -0.064 & 0.000 & 0.833 \\
\hline 323456455 & 59830 & Ribosomal protein & 0.333 & 0.333 & 2.333 & -0.051 & -0.019 & -0.670 & 0.143 & 0.143 \\
\hline 323454954 & 71078 & Calmodulin & 0.333 & 0.333 & 2.667 & -0.030 & -0.010 & -0.670 & 0.125 & 0.125 \\
\hline 323451287 & 28200 & Argininosuccinate lyase & 1.000 & 0.667 & 0.000 & -0.100 & -0.300 & -0.360 & $\mathrm{~N} / \mathrm{A}$ & $\mathrm{N} / \mathrm{A}$ \\
\hline 323454341 & 9008 & Thioredoxin domain 2 & 0.000 & 0.667 & 2.667 & -0.006 & -0.029 & -0.330 & 0.000 & 0.250 \\
\hline 323448003 & 67583 & Hypothetical protein & 0.667 & 0.000 & 0.667 & -0.640 & -0.210 & -0.180 & 1.000 & 0.000 \\
\hline 323450849 & 7494 & Protein of plotosystem II & 1.000 & 1.333 & 1.000 & -0.600 & -0.600 & -0.630 & 1.000 & 1.333 \\
\hline 323446625 & 72830 & $\begin{array}{l}\text { Transcriptional regulatory } \\
\text { protein algP }\end{array}$ & 1.333 & 1.000 & 1.000 & -0.430 & -0.570 & -0.340 & 1.333 & 1.000 \\
\hline 323451064 & 77836 & $\begin{array}{l}\text { Chloroplast light harvesting } \\
\text { protein }\end{array}$ & 0.667 & 1.333 & 0.667 & -0.640 & -0.430 & -0.500 & 1.000 & 2.000 \\
\hline
\end{tabular}




\begin{tabular}{|c|c|c|c|c|c|c|c|c|c|c|}
\hline 323456234 & 61432 & $\begin{array}{l}\text { NADH-quinone } \\
\text { oxidoreductase subunit }\end{array}$ & 1.667 & 0.667 & 1.000 & -0.300 & -0.410 & -0.120 & 1.667 & 0.667 \\
\hline 323455839 & 61607 & Generic methyltransferase & 1.667 & 1.000 & 0.667 & -0.180 & -0.590 & -0.210 & 2.500 & 1.500 \\
\hline 323449225 & 59414 & $\begin{array}{l}\text { Bifunctional aspartate } \\
\text { kinase/homoserine } \\
\text { dehydrogenase }\end{array}$ & 1.000 & 1.667 & 0.667 & -0.440 & -0.310 & -0.540 & 1.500 & 2.500 \\
\hline 323453705 & 37129 & Ammonium transporter & 0.667 & 2.333 & 2.333 & -0.080 & -0.360 & -0.190 & 0.286 & 1.000 \\
\hline 323446944 & 72810 & Hypothetical protein & 0.667 & 1.000 & 1.333 & -0.400 & -0.400 & -0.640 & 0.500 & 0.750 \\
\hline 323446659 & 72828 & ATPase & 1.000 & 1.667 & 0.333 & -0.270 & -0.160 & -0.540 & 3.000 & 5.000 \\
\hline 323451333 & 27870 & Ribosomal Protein & 0.000 & 1.333 & 1.000 & -0.150 & -0.600 & -0.110 & 0.000 & 1.333 \\
\hline 323456908 & 70598 & Acetyl-coenzyme A synthetase & 1.333 & 0.667 & 0.333 & -0.150 & -0.570 & -0.210 & 4.000 & 2.000 \\
\hline 323454832 & 62132 & TPR repeat containing protein & 0.000 & 1.333 & 1.667 & -0.042 & -0.390 & -0.110 & 0.000 & 0.800 \\
\hline 323455019 & 13348 & $\begin{array}{l}\text { Carbamoylphosphate } \\
\text { synthetase } 2 / \text { aspartate } \\
\text { transcarbamylase/dihydroorota } \\
\text { se }\end{array}$ & 0.667 & 2.000 & 0.333 & -0.450 & -0.098 & -0.270 & 2.000 & 6.000 \\
\hline 323454055 & 36910 & Ribosomal protein & 0.333 & 0.667 & 1.667 & -0.140 & -0.160 & -0.610 & 0.200 & 0.400 \\
\hline 323450361 & 29693 & Triosephosphate isomerase & 0.000 & 2.000 & 1.333 & -0.080 & -0.490 & -0.037 & 0.000 & 1.500 \\
\hline 323453878 & 71352 & Aspartyl-tRNA synthetase & 0.333 & 1.000 & 1.333 & -0.230 & -0.400 & -0.440 & 0.250 & 0.750 \\
\hline 323451615 & 71802 & $\begin{array}{l}\text { Methionyl/Aminoacyl-tRNA } \\
\text { synthetase }\end{array}$ & 0.667 & 2.000 & 0.000 & -0.220 & -0.026 & -0.270 & N/A & $\mathrm{N} / \mathrm{A}$ \\
\hline 323451627 & 12112 & $\mathrm{Na}+/ \mathrm{H}+$ antiporter $\mathrm{NhaA}$ & 0.000 & 1.333 & 2.000 & -0.022 & -0.270 & -0.110 & 0.000 & 0.667 \\
\hline 323446387 & 68761 & $\begin{array}{l}\mathrm{KH} \text { domain for binding } \\
\text { nucleic acids }\end{array}$ & 0.667 & 2.000 & 0.667 & -0.640 & -0.210 & -0.270 & 1.000 & 3.000 \\
\hline 323454189 & 7695 & Ribosomal protein & 0.000 & 1.000 & 1.667 & -0.042 & -0.270 & -0.190 & 0.000 & 0.600 \\
\hline 323453547 & 59995 & Prohibitin & 2.000 & 0.667 & 0.000 & -0.011 & -0.300 & -0.066 & $\mathrm{~N} / \mathrm{A}$ & $\mathrm{N} / \mathrm{A}$ \\
\hline 323454570 & 71153 & Hypothetical protein & 0.667 & 2.667 & 0.000 & -0.220 & -0.008 & -0.130 & $\mathrm{~N} / \mathrm{A}$ & $\mathrm{N} / \mathrm{A}$ \\
\hline 323453434 & 37238 & Nitrite reductase & 0.000 & 2.333 & 1.000 & -0.150 & -0.260 & -0.021 & 0.000 & 2.333 \\
\hline 323456737 & 70513 & $\begin{array}{l}\text { Inorganic phosphate } \\
\text { transporter }\end{array}$ & 2.333 & 1.333 & 0.000 & -0.005 & -0.089 & -0.130 & $\mathrm{~N} / \mathrm{A}$ & N/A \\
\hline 323457185 & 52040 & Adaptin & 0.000 & 2.333 & 1.000 & -0.150 & -0.260 & -0.021 & 0.000 & 2.333 \\
\hline 323455015 & 52760 & $\begin{array}{l}\text { Cycloartenol-C24- } \\
\text { methyltransferase }\end{array}$ & 2.333 & 0.333 & 0.000 & -0.005 & -0.550 & -0.012 & $\mathrm{~N} / \mathrm{A}$ & $\mathrm{N} / \mathrm{A}$ \\
\hline 323452327 & 71640 & Zn-finger & 0.667 & 1.333 & 0.000 & -0.220 & -0.089 & -0.500 & $\mathrm{~N} / \mathrm{A}$ & $\mathrm{N} / \mathrm{A}$ \\
\hline 323449390 & 54723 & Exportin & 2.333 & 0.667 & 0.000 & -0.005 & -0.300 & -0.035 & $\mathrm{~N} / \mathrm{A}$ & $\mathrm{N} / \mathrm{A}$ \\
\hline 323456463 & 69639 & Hypothetical protein & 1.000 & 1.000 & 1.000 & -0.600 & -0.570 & -0.500 & 1.000 & 1.000 \\
\hline 323456395 & 1116 & $\begin{array}{l}\text { Eukaryotic translation } \\
\text { initiation factor }\end{array}$ & 0.667 & 1.333 & 0.667 & -0.640 & -0.430 & -0.500 & 1.000 & 2.000 \\
\hline 323455383 & 58678 & Phenylalanyl-tRNA synthetase & 1.667 & 1.000 & 0.333 & -0.083 & -0.380 & -0.210 & 5.000 & 3.000 \\
\hline 323451360 & 28035 & Chorismate synthase & 0.667 & 0.667 & 1.000 & -0.560 & -0.410 & -0.560 & 0.667 & 0.667 \\
\hline 323449322 & 38625 & Isopropylmalate synthase & 1.667 & 1.000 & 0.667 & -0.180 & -0.590 & -0.210 & 2.500 & 1.500 \\
\hline 323456879 & 18780 & Protease & 0.667 & 0.667 & 1.667 & -0.280 & -0.160 & -0.560 & 0.400 & 0.400 \\
\hline 323455013 & 22474 & Ankyrin & 0.000 & 1.333 & 1.333 & -0.080 & -0.530 & -0.110 & 0.000 & 1.000 \\
\hline 323451434 & 28009 & Hypothetical protein & 1.000 & 1.333 & 0.333 & -0.270 & -0.250 & -0.630 & 3.000 & 4.000 \\
\hline 323450398 & 3154 & $\begin{array}{l}\text { Plastidic triose- } \\
\text { phosphate/phosphate } \\
\text { translocator }\end{array}$ & 1.667 & 1.000 & 0.000 & -0.023 & -0.160 & -0.210 & $\mathrm{~N} / \mathrm{A}$ & $\mathrm{N} / \mathrm{A}$ \\
\hline 323447220 & 68254 & Hypothetical protein & 0.667 & 1.667 & 0.000 & -0.220 & -0.048 & -0.370 & $\mathrm{~N} / \mathrm{A}$ & $\mathrm{N} / \mathrm{A}$ \\
\hline 323446727 & 34875 & $\begin{array}{l}\text { Cobalanin-requiring } \\
\text { methionine synthase }\end{array}$ & 0.333 & 2.000 & 0.333 & -0.720 & -0.098 & -0.130 & 1.000 & 6.000 \\
\hline 323452805 & 71598 & $\begin{array}{l}\text { NADPH protochlorophyllide } \\
\text { reductase }\end{array}$ & 1.333 & 0.333 & 0.667 & -0.290 & -0.430 & -0.110 & 2.000 & 0.500 \\
\hline 323453262 & 71507 & $\begin{array}{l}\text { Serine/threonine-protein } \\
\text { kinase }\end{array}$ & 0.000 & 1.000 & 2.000 & -0.022 & -0.170 & -0.190 & 0.000 & 0.500 \\
\hline 323448712 & 67109 & Thiolase & 0.333 & 0.667 & 0.667 & -0.550 & -0.620 & -0.610 & 0.500 & 1.000 \\
\hline 323457297 & 18821 & Myosin & 1.667 & 0.667 & 0.000 & -0.023 & -0.300 & -0.120 & $\mathrm{~N} / \mathrm{A}$ & $\mathrm{N} / \mathrm{A}$ \\
\hline 323456351 & 77802 & $\begin{array}{l}\text { Chloroplast light harvesting } \\
\text { protein }\end{array}$ & 1.333 & 1.667 & 0.000 & -0.048 & -0.048 & -0.580 & N/A & N/A \\
\hline 323449561 & 38491 & Ribosomal protein & 0.000 & 1.333 & 1.333 & -0.080 & -0.530 & -0.110 & 0.000 & 1.000 \\
\hline 323454302 & 23053 & \begin{tabular}{|l} 
Protease \\
\end{tabular} & 1.667 & 1.000 & 0.333 & -0.083 & -0.380 & -0.210 & 5.000 & 3.000 \\
\hline 323453584 & 24204 & Ribosomal protein & 0.000 & 1.333 & 0.333 & -0.530 & -0.250 & -0.110 & 0.000 & 4.000 \\
\hline 323450277 & 29821 & Ribosomal Protein & 0.000 & 1.000 & 1.333 & -0.080 & -0.400 & -0.190 & 0.000 & 0.750 \\
\hline 323450718 & 29089 & $\begin{array}{l}\text { Photosystem II } \\
\text { stability/assembly factor }\end{array}$ & 2.333 & 0.333 & 0.333 & -0.023 & -0.700 & -0.012 & 7.000 & 1.000 \\
\hline
\end{tabular}




\begin{tabular}{|c|c|c|c|c|c|c|c|c|c|c|}
\hline 323452552 & 60080 & Proteasome & 0.000 & 0.667 & 2.000 & -0.022 & -0.092 & -0.330 & 0.000 & 0.333 \\
\hline 323452930 & 1689 & $\mathrm{ABC}$ transporter & 1.333 & 7.000 & 0.667 & -0.016 & -0.001 & -0.230 & 2.000 & 10.500 \\
\hline 323449871 & 54528 & $\begin{array}{l}\text { HMG-CoA lyase-like, Alpha- } \\
\text { isopropylmalate/homocitrate } \\
\text { synthase }\end{array}$ & 2.000 & 0.333 & 0.000 & -0.011 & -0.550 & -0.026 & $\mathrm{~N} / \mathrm{A}$ & $\mathrm{N} / \mathrm{A}$ \\
\hline 323447741 & 55500 & Nonaspanin & 0.000 & 2.333 & 0.333 & -0.530 & -0.060 & -0.021 & 0.000 & 7.000 \\
\hline 242620028 & & 30 S ribosomal protein $\mathrm{S} 2$ & 0.000 & 2.667 & 0.333 & -0.530 & -0.036 & -0.012 & 0.000 & 8.000 \\
\hline 323454310 & 52969 & Adenosine kinase & 0.000 & 2.667 & 0.000 & -1.000 & -0.008 & -0.012 & $\mathrm{~N} / \mathrm{A}$ & $\mathrm{N} / \mathrm{A}$ \\
\hline 323451431 & 77818 & $\begin{array}{l}\text { Chloroplast light harvesting } \\
\text { protein }\end{array}$ & 0.000 & 2.000 & 6.000 & -0.110 & -0.240 & -0.330 & 0.000 & 0.333 \\
\hline 323453970 & 60001 & Hypothetical protein & 1.000 & 1.333 & 0.333 & -0.270 & -0.250 & -0.630 & 3.000 & 4.000 \\
\hline 323451979 & 78108 & Selenoprotein & 0.333 & 1.333 & 1.000 & -0.360 & -0.600 & -0.300 & 0.333 & 1.333 \\
\hline 323454125 & 71117 & $\mathrm{ABC}$ transporter & 1.333 & 1.000 & 0.000 & -0.048 & -0.160 & -0.340 & $\mathrm{~N} / \mathrm{A}$ & $\mathrm{N} / \mathrm{A}$ \\
\hline 323448681 & 32244 & KDPG and KHG aldolase & 1.000 & 0.333 & 1.000 & -0.600 & -0.250 & -0.210 & 1.000 & 0.333 \\
\hline 323449180 & 66715 & Mannosyltransferase & 1.333 & 0.000 & 1.333 & -0.570 & -0.043 & -0.032 & 1.000 & 0.000 \\
\hline 323450841 & 28553 & Electron transfer flavoprotein & 1.000 & 1.000 & 0.333 & -0.270 & -0.380 & -0.500 & 3.000 & 3.000 \\
\hline 323456793 & 18389 & Nuclear transport factor 2 & 0.333 & 1.333 & 0.667 & -0.550 & -0.430 & -0.300 & 0.500 & 2.000 \\
\hline 323449211 & 38723 & PAS & 0.000 & 1.333 & 1.333 & -0.080 & -0.530 & -0.110 & 0.000 & 1.000 \\
\hline 323451135 & 37911 & Proteasome & 0.000 & 1.000 & 1.667 & -0.042 & -0.270 & -0.190 & 0.000 & 0.600 \\
\hline 323456300 & 61455 & CreA family protein & 1.333 & 0.333 & 1.000 & -0.430 & -0.250 & -0.110 & 1.333 & 0.333 \\
\hline 323452724 & 25961 & Hypothetical protein & 1.000 & 1.000 & 0.667 & -0.440 & -0.590 & -0.500 & 1.500 & 1.500 \\
\hline 323448268 & 33034 & Aldo/keto reductase & 0.667 & 1.333 & 0.333 & -0.450 & -0.250 & -0.500 & 2.000 & 4.000 \\
\hline 323450964 & 28667 & Mannitol phosphate & 0.333 & 1.000 & 1.000 & -0.360 & -0.570 & -0.440 & 0.333 & 1.000 \\
\hline 323452169 & 5924 & Hypothetical protein & 0.667 & 2.000 & 0.000 & -0.220 & -0.026 & -0.270 & $\mathrm{~N} / \mathrm{A}$ & $\mathrm{N} / \mathrm{A}$ \\
\hline 323451897 & 59068 & Nucleolar protein Nop56 & 0.333 & 0.333 & 2.000 & -0.086 & -0.037 & -0.670 & 0.167 & 0.167 \\
\hline 323448884 & 55034 & Proteasome & 0.000 & 1.000 & 1.667 & -0.042 & -0.270 & -0.190 & 0.000 & 0.600 \\
\hline 323454580 & 70105 & Glutathione peroxidase & 1.333 & 1.000 & 0.000 & -0.048 & -0.160 & -0.340 & $\mathrm{~N} / \mathrm{A}$ & $\mathrm{N} / \mathrm{A}$ \\
\hline 242620059 & & 30 S ribosomal protein SI3 & 0.000 & 1.333 & 1.333 & -0.080 & -0.530 & -0.110 & 0.000 & 1.000 \\
\hline 323451363 & 14994 & $\begin{array}{l}\text { Phospholipid/glycerol } \\
\text { acyltransferase }\end{array}$ & 0.667 & 2.000 & 0.000 & -0.220 & -0.026 & -0.270 & $\mathrm{~N} / \mathrm{A}$ & $\mathrm{N} / \mathrm{A}$ \\
\hline 323448448 & 32655 & Nonphototropic hypocotyl & 0.000 & 0.333 & 2.333 & -0.012 & -0.019 & -0.580 & 0.000 & 0.143 \\
\hline 242620055 & & 50 S ribosomal protein L6 & 0.000 & 0.333 & 2.333 & -0.012 & -0.019 & -0.580 & 0.000 & 0.143 \\
\hline 323454894 & 22512 & $\begin{array}{l}\text { Formylglycineamide ribotide } \\
\text { amidotransferase }\end{array}$ & 0.000 & 2.667 & 0.000 & -1.000 & -0.008 & -0.012 & $\mathrm{~N} / \mathrm{A}$ & $\mathrm{N} / \mathrm{A}$ \\
\hline 323449382 & 38538 & Glutamate synthase & 0.000 & 1.000 & 0.000 & -1.000 & -0.160 & -0.190 & $\mathrm{~N} / \mathrm{A}$ & $\mathrm{N} / \mathrm{A}$ \\
\hline 323448821 & 70378 & ATPase, proteasome & 1.000 & 1.000 & 0.000 & -0.100 & -0.160 & -0.500 & $\mathrm{~N} / \mathrm{A}$ & $\mathrm{N} / \mathrm{A}$ \\
\hline 323450953 & 28840 & Epsilon1-COP & 0.667 & 1.667 & 0.000 & -0.220 & -0.048 & -0.370 & $\mathrm{~N} / \mathrm{A}$ & $\mathrm{N} / \mathrm{A}$ \\
\hline 323451761 & 27287 & mRNA binding protein & 0.667 & 1.000 & 0.333 & -0.450 & -0.380 & -0.640 & 2.000 & 3.000 \\
\hline 323445273 & 9896 & Proteasome & 0.000 & 0.667 & 1.667 & -0.042 & -0.160 & -0.330 & 0.000 & 0.400 \\
\hline 323457195 & 19173 & Ribosomal Protein & 0.000 & 0.667 & 1.667 & -0.042 & -0.160 & -0.330 & 0.000 & 0.400 \\
\hline 323450275 & 1254 & Lysyl-tRNA synthetase & 0.333 & 1.333 & 0.667 & -0.550 & -0.430 & -0.300 & 0.500 & 2.000 \\
\hline 323456994 & 58606 & Glycyl tRNA synthetase & 1.000 & 1.000 & 0.333 & -0.270 & -0.380 & -0.500 & 3.000 & 3.000 \\
\hline 323451216 & 28476 & Ribosomal protein & 0.000 & 0.667 & 1.667 & -0.042 & -0.160 & -0.330 & 0.000 & 0.400 \\
\hline 323449910 & 38303 & $\begin{array}{l}\text { Rhamnose biosynthetic } \\
\text { enzyme } 1\end{array}$ & 0.333 & 0.667 & 0.000 & -0.470 & -0.300 & -0.610 & $\mathrm{~N} / \mathrm{A}$ & $\mathrm{N} / \mathrm{A}$ \\
\hline 323453288 & 24967 & Glutamyl-tRNA reductase & 0.667 & 0.333 & 0.333 & -0.450 & -0.700 & -0.390 & 2.000 & 1.000 \\
\hline 323454888 & 21939 & $\begin{array}{l}\text { S-adenosylmethionine- } \\
\text { dependent methyltransferase } \\
\text { activity }\end{array}$ & 0.333 & 1.333 & 0.000 & -0.470 & -0.089 & -0.300 & $N / A$ & $\mathrm{~N} / \mathrm{A}$ \\
\hline 323455339 & 21514 & Ribosomal protein & 0.000 & 0.333 & 1.333 & -0.080 & -0.140 & -0.580 & 0.000 & 0.250 \\
\hline 323454405 & 22805 & Aminoacyl-tRNA synthetase & 0.000 & 1.333 & 0.667 & -0.280 & -0.430 & -0.110 & 0.000 & 2.000 \\
\hline 323449847 & 72183 & Proteasome & 0.000 & 1.000 & 0.667 & -0.280 & -0.590 & -0.190 & 0.000 & 1.500 \\
\hline 323457245 & 19010 & Aminoacyl-tRNA synthetase & 1.000 & 1.000 & 0.000 & -0.100 & -0.160 & -0.500 & $\mathrm{~N} / \mathrm{A}$ & $\mathrm{N} / \mathrm{A}$ \\
\hline 323453077 & 16 & $\begin{array}{l}\text { Dynein heavy chain, AAA } \\
\text { ATPase }\end{array}$ & 1.000 & 0.000 & 0.000 & -0.100 & -1.000 & -0.076 & $\mathrm{~N} / \mathrm{A}$ & $\mathrm{N} / \mathrm{A}$ \\
\hline 323454617 & 71135 & $\begin{array}{l}\text { GCN5-related N- } \\
\text { acetyltransferase }\end{array}$ & 0.667 & 0.333 & 1.000 & -0.560 & -0.250 & -0.390 & 0.667 & 0.333 \\
\hline 323454603 & 71137 & Prolyl 4-liydroxylase & 1.000 & 1.000 & 0.000 & -0.100 & -0.160 & -0.500 & $\mathrm{~N} / \mathrm{A}$ & $\mathrm{N} / \mathrm{A}$ \\
\hline 323447558 & 34011 & $\begin{array}{l}\text { Glutamine } \\
\text { amidotransferase/cyclase }\end{array}$ & 1.000 & 0.667 & 0.333 & -0.270 & -0.570 & -0.360 & 3.000 & 2.000 \\
\hline 323451314 & 64822 & Tnks; tankyrase & 1.000 & 0.667 & 0.333 & -0.270 & -0.570 & -0.360 & 3.000 & 2.000 \\
\hline 323455735 & 70885 & $\begin{array}{l}\text { Vacuolar-type } \mathrm{H}^{+-} \\
\text {translocating inorganic } \\
\text { pyrophosphatase }\end{array}$ & 0.333 & 1.000 & 1.333 & -0.140 & -0.390 & -0.300 & 0.250 & 0.750 \\
\hline 323451825 & 2849 & Squalene synthase & 0.667 & 0.667 & 0.667 & -0.640 & -0.620 & -0.560 & 1.000 & 1.000 \\
\hline 323453323 & 60042 & Elongation factor & 0.667 & 1.000 & 0.000 & -0.220 & -0.160 & -0.640 & N/A & $\mathrm{N} / \mathrm{A}$ \\
\hline
\end{tabular}




\begin{tabular}{|c|c|c|c|c|c|c|c|c|c|c|}
\hline 323451463 & 59127 & $\begin{array}{l}\text { SecA-type chloroplast protein } \\
\text { transport factor }\end{array}$ & 1.333 & 0.333 & 0.000 & -0.048 & -0.550 & -0.110 & $\mathrm{~N} / \mathrm{A}$ & $\mathrm{N} / \mathrm{A}$ \\
\hline 242620084 & & $30 \mathrm{~S}$ ribosomal protein $\mathrm{S} 14$ & 0.000 & 0.667 & 1.000 & -0.150 & -0.410 & -0.330 & 0.000 & 0.667 \\
\hline 323446340 & 68788 & $\begin{array}{l}\text { AMP-dependent synthetase } \\
\text { and ligase }\end{array}$ & 1.000 & 0.667 & 0.333 & -0.270 & -0.570 & -0.360 & 3.000 & 2.000 \\
\hline 242620063 & & $30 \mathrm{~S}$ ribosomal protein $\mathrm{S} 9$ & 0.000 & 1.000 & 1.000 & -0.150 & -0.570 & -0.190 & 0.000 & 1.000 \\
\hline 323450284 & 4661 & Aldose 1-epimerase & 0.333 & 0.667 & 0.667 & -0.550 & -0.620 & -0.610 & 0.500 & 1.000 \\
\hline 323456303 & 52378 & Glutaminyl-tRNA synthetase & 0.333 & 1.000 & 0.333 & -0.720 & -0.380 & -0.440 & 1.000 & 3.000 \\
\hline 323449383 & 54714 & Ribosomal protein & 0.000 & 1.333 & 0.667 & -0.280 & -0.430 & -0.110 & 0.000 & 2.000 \\
\hline 323450814 & 28676 & Ubiquitin-activating enzyme & 0.333 & 1.000 & 0.000 & -0.470 & -0.160 & -0.440 & $\mathrm{~N} / \mathrm{A}$ & $\mathrm{N} / \mathrm{A}$ \\
\hline 323448551 & 32534 & Prolyl-tRNA synthetase & 0.667 & 0.333 & 0.333 & -0.450 & -0.700 & -0.390 & 2.000 & 1.000 \\
\hline 323453669 & 23934 & Sodium dependent transporter & 0.333 & 1.000 & 0.000 & -0.470 & -0.160 & -0.440 & $\mathrm{~N} / \mathrm{A}$ & $\mathrm{N} / \mathrm{A}$ \\
\hline 323452581 & 26043 & Chaperonin & 0.000 & 1.667 & 0.000 & -1.000 & -0.048 & -0.064 & $\mathrm{~N} / \mathrm{A}$ & N/A \\
\hline 323454658 & 23725 & Cytochrome precurser & 2.333 & 0.000 & 11.000 & 0.000 & 0.000 & -0.170 & 0.212 & 0.000 \\
\hline 323451614 & 71803 & $\begin{array}{l}\text { Insulinase-like, Mitochondrial } \\
\text { substrate carrier }\end{array}$ & 0.000 & 0.000 & 1.333 & -0.080 & -0.043 & -1.000 & 0.000 & 0.000 \\
\hline 323450997 & 28593 & LMP7-like protein & 0.000 & 0.000 & 1.333 & -0.080 & -0.043 & -1.000 & 0.000 & 0.000 \\
\hline 323449787 & 72138 & Hedgehog protein & 1.333 & 0.000 & 0.000 & -0.048 & -1.000 & -0.032 & $\mathrm{~N} / \mathrm{A}$ & N/A \\
\hline 323447426 & 39368 & Isoleucine trna synthetase & 0.667 & 1.000 & 0.000 & -0.220 & -0.160 & -0.640 & $\mathrm{~N} / \mathrm{A}$ & $\mathrm{N} / \mathrm{A}$ \\
\hline 323449971 & 30237 & Phypo stress protein & 0.667 & 1.000 & 0.000 & -0.220 & -0.160 & -0.640 & $\mathrm{~N} / \mathrm{A}$ & $\mathrm{N} / \mathrm{A}$ \\
\hline 323449093 & 3405 & Protein kinase & 0.333 & 1.000 & 0.333 & -0.720 & -0.380 & -0.440 & 1.000 & 3.000 \\
\hline 323455262 & 11148 & tRNA synthetases & 0.333 & 0.333 & 1.000 & -0.360 & -0.250 & -0.670 & 0.333 & 0.333 \\
\hline 323455416 & 52464 & $\begin{array}{l}\text { Geranylgeranyl diphosphate } \\
\text { synthase }\end{array}$ & 0.667 & 0.333 & 0.667 & -0.640 & -0.430 & -0.390 & 1.000 & 0.500 \\
\hline 323454215 & 71160 & Hypothetical protein & 0.333 & 1.333 & 0.000 & -0.470 & -0.089 & -0.300 & $\mathrm{~N} / \mathrm{A}$ & N/A \\
\hline 323448527 & 67169 & Protein phosphatase. ankyrin & 0.333 & 1.333 & 0.000 & -0.470 & -0.089 & -0.300 & N/A & $\mathrm{N} / \mathrm{A}$ \\
\hline 323454082 & 52773 & Ribosomal Protein & 0.000 & 1.000 & 0.667 & -0.280 & -0.590 & -0.190 & 0.000 & 1.500 \\
\hline 323450170 & 65948 & Hypothetical protein & 0.333 & 0.667 & 0.667 & -0.550 & -0.620 & -0.610 & 0.500 & 1.000 \\
\hline 323450794 & 54097 & Ubiquitin-activating enzyme & 0.000 & 1.000 & 0.333 & -0.530 & -0.380 & -0.190 & 0.000 & 3.000 \\
\hline 323453528 & 62976 & WW/Rsp5/WWP & 0.000 & 1.000 & 0.333 & -0.530 & -0.380 & -0.190 & 0.000 & 3.000 \\
\hline 323448800 & 70381 & ATP-dependent RNA helicase & 0.000 & 1.333 & 0.000 & -1.000 & -0.089 & -0.110 & $\mathrm{~N} / \mathrm{A}$ & N/A \\
\hline 323449569 & 70314 & $\begin{array}{l}\text { Coatomer WD associated } \\
\text { region }\end{array}$ & 1.000 & 0.333 & 0.000 & -0.100 & -0.550 & -0.210 & $\mathrm{~N} / \mathrm{A}$ & $\mathrm{N} / \mathrm{A}$ \\
\hline 323448946 & 31792 & $\begin{array}{l}\text { Anthranilate } \\
\text { phosphoribosyltransferase }\end{array}$ & 0.667 & 0.000 & 0.000 & -0.220 & -1.000 & -0.180 & $\mathrm{~N} / \mathrm{A}$ & $\mathrm{N} / \mathrm{A}$ \\
\hline 323452026 & 59047 & Alcohol dehydrogenase & 1.667 & 0.000 & 0.000 & -0.023 & -1.000 & -0.014 & $\mathrm{~N} / \mathrm{A}$ & $\mathrm{N} / \mathrm{A}$ \\
\hline 323451541 & 6384 & Ras small GTPase & 0.000 & 1.667 & 0.000 & -1.000 & -0.048 & -0.064 & $\mathrm{~N} / \mathrm{A}$ & $\mathrm{N} / \mathrm{A}$ \\
\hline 323448259 & 60333 & Mitochondrial carrier protein & 1.333 & 0.333 & 0.000 & -0.048 & -0.550 & -0.110 & $\mathrm{~N} / \mathrm{A}$ & $\mathrm{N} / \mathrm{A}$ \\
\hline 323457329 & 19506 & $\begin{array}{l}\text { Proteasome non-ATPase } \\
\text { regulatory subunit }\end{array}$ & 0.000 & 1.333 & 0.000 & -1.000 & -0.089 & -0.110 & $\mathrm{~N} / \mathrm{A}$ & $\mathrm{N} / \mathrm{A}$ \\
\hline 323454107 & 36667 & Tyrosine protein kinase & 0.000 & 1.000 & 0.000 & -1.000 & -0.160 & -0.190 & $\mathrm{~N} / \mathrm{A}$ & N/A \\
\hline 323447825 & 39241 & $\mathrm{MCM}$ & 0.000 & 1.000 & 0.000 & -1.000 & -0.160 & -0.190 & $\mathrm{~N} / \mathrm{A}$ & $\mathrm{N} / \mathrm{A}$ \\
\hline 323451030 & 2169 & $\begin{array}{l}\text { DEAD/DEAH box helicase } \\
\text { domain-containing protein }\end{array}$ & 1.333 & 0.000 & 0.000 & -0.048 & -1.000 & -0.032 & $\mathrm{~N} / \mathrm{A}$ & $\mathrm{N} / \mathrm{A}$ \\
\hline 323453797 & 63307 & Chloroplast Chaperonin & 1.000 & 0.000 & 0.333 & -0.270 & -0.450 & -0.076 & 3.000 & 0.000 \\
\hline 323452541 & 78110 & Selenoprotein & 0.000 & 0.000 & 1.333 & -0.080 & -0.043 & -1.000 & 0.000 & 0.000 \\
\hline 323446199 & 68863 & $\begin{array}{l}\text { Cell wall surface anchor } \\
\text { protein }\end{array}$ & 0.000 & 0.000 & 2.000 & -0.190 & -0.037 & -0.390 & 0.000 & 0.000 \\
\hline 323450033 & 54443 & Acyl-CoA synthetase & 0.333 & 0.333 & 0.667 & -0.550 & -0.430 & -0.670 & 0.500 & 0.500 \\
\hline 323447566 & 59628 & Phosphoglucomutase & 1.000 & 0.333 & 0.000 & -0.100 & -0.550 & -0.210 & $\mathrm{~N} / \mathrm{A}$ & $\mathrm{N} / \mathrm{A}$ \\
\hline 323455362 & 21520 & $\begin{array}{l}\text { Ribose-phosphate } \\
\text { pyrophosphokinase }\end{array}$ & 0.333 & 1.000 & 0.000 & -0.470 & -0.160 & -0.440 & $\mathrm{~N} / \mathrm{A}$ & $\mathrm{N} / \mathrm{A}$ \\
\hline 323452894 & 63896 & Contain SPX, N-terminal & 1.000 & 0.333 & 0.000 & -0.100 & -0.550 & -0.210 & $\mathrm{~N} / \mathrm{A}$ & $\mathrm{N} / \mathrm{A}$ \\
\hline 323454860 & 62184 & Predicted membrane protein & 0.000 & 0.333 & 1.000 & -0.150 & -0.250 & -0.580 & 0.000 & 0.333 \\
\hline 323450018 & 72128 & Inorganic pyrophosphatase & 1.000 & 0.333 & 0.000 & -0.100 & -0.550 & -0.210 & $\mathrm{~N} / \mathrm{A}$ & $\mathrm{N} / \mathrm{A}$ \\
\hline 323451609 & 37770 & Alanine transaminase & 0.667 & 0.667 & 0.000 & -0.220 & -0.300 & -0.560 & $\mathrm{~N} / \mathrm{A}$ & $\mathrm{N} / \mathrm{A}$ \\
\hline 323454420 & 58861 & Phosphoglycerate kinase & 1.000 & 1.000 & 0.000 & -0.100 & -0.160 & -0.500 & $\mathrm{~N} / \mathrm{A}$ & $\mathrm{N} / \mathrm{A}$ \\
\hline 323456665 & 70491 & RNA binding region & 0.000 & 1.333 & 0.000 & -1.000 & -0.089 & -0.110 & $\mathrm{~N} / \mathrm{A}$ & $\mathrm{N} / \mathrm{A}$ \\
\hline 323454572 & 52868 & \begin{tabular}{|l|} 
Acyltransferase region, \\
Thioestarase
\end{tabular} & 0.667 & 0.000 & 0.333 & -0.450 & -0.450 & -0.180 & 2.000 & 0.000 \\
\hline 323452696 & 26083 & $\begin{array}{l}\text { Methylmalonate-semialdehyde } \\
\text { dehydrogenase }\end{array}$ & 0.000 & 0.667 & 0.333 & -0.530 & -0.570 & -0.330 & 0.000 & 2.000 \\
\hline 323447245 & 34382 & Monooxygenase & 0.333 & 0.000 & 0.667 & -0.550 & -0.210 & -0.420 & 0.500 & 0.000 \\
\hline 323452117 & 59057 & \begin{tabular}{|l|} 
Delta l-pyrroline-5- \\
carboxylate reductase (P5CR)
\end{tabular} & 0.000 & 1.000 & 0.000 & -1.000 & -0.160 & -0.190 & N/A & $\mathrm{N} / \mathrm{A}$ \\
\hline
\end{tabular}




\begin{tabular}{|c|c|c|c|c|c|c|c|c|c|c|}
\hline 323455706 & 550 & AAA ATPase & 0.000 & 1.333 & 0.667 & -0.080 & -0.610 & -0.064 & 0.000 & 2.000 \\
\hline 323456297 & 70759 & Aldehyde dehydrogenase & 0.000 & 1.000 & 0.000 & -1.000 & -0.160 & -0.190 & $\mathrm{~N} / \mathrm{A}$ & $\mathrm{N} / \mathrm{A}$ \\
\hline 323446517 & 72838 & $\begin{array}{l}\text { Vacuolar sorting receptor } \\
\text { protein }\end{array}$ & 0.000 & 0.000 & 1.000 & -0.150 & -0.094 & -1.000 & 0.000 & 0.000 \\
\hline 323453809 & 24439 & Phosphoglucomutase & 0.000 & 0.000 & 1.000 & -0.150 & -0.094 & -1.000 & 0.000 & 0.000 \\
\hline 323446697 & 60388 & $\begin{array}{l}\text { 3-hydroxyacyl-CoA } \\
\text { dehydrogenase }\end{array}$ & 0.000 & 1.000 & 0.000 & -1.000 & -0.160 & -0.190 & N/A & $\mathrm{N} / \mathrm{A}$ \\
\hline 323449869 & 70285 & $\begin{array}{l}\text { Tryptophanyl-tRNA } \\
\text { synthetase }\end{array}$ & 0.000 & 1.000 & 0.000 & -1.000 & -0.160 & -0.190 & N/A & N/A \\
\hline 323450473 & 72024 & Calcium-binding EF hand & 0.667 & 0.667 & 0.000 & -0.220 & -0.300 & -0.560 & $\mathrm{~N} / \mathrm{A}$ & $\mathrm{N} / \mathrm{A}$ \\
\hline 323447373 & 59650 & $\begin{array}{l}\text { Deoxyxylulose-5-phosphate } \\
\text { synthase }\end{array}$ & 0.667 & 0.000 & 0.000 & -0.220 & -1.000 & -0.180 & $\mathrm{~N} / \mathrm{A}$ & $\mathrm{N} / \mathrm{A}$ \\
\hline 323447574 & 67977 & $\begin{array}{l}\text { Dynein heavy chain, AAA } \\
\text { ATPase } \\
\end{array}$ & 0.000 & 0.667 & 0.000 & -1.000 & -0.300 & -0.330 & $\mathrm{~N} / \mathrm{A}$ & $\mathrm{N} / \mathrm{A}$ \\
\hline 323456247 & 58667 & Skp-1 component & 0.000 & 0.000 & 1.000 & -0.150 & -0.094 & -1.000 & 0.000 & 0.000 \\
\hline 323446558 & 35012 & Ribosomal protein & 0.000 & 0.000 & 1.333 & -0.080 & -0.043 & -1.000 & 0.000 & 0.000 \\
\hline 323447255 & 59665 & N-Acetyl-L-glutamate kinase & 0.000 & 1.000 & 0.000 & -1.000 & -0.160 & -0.190 & $\mathrm{~N} / \mathrm{A}$ & $\mathrm{N} / \mathrm{A}$ \\
\hline 323447748 & 39278 & AAA ATPase & 0.000 & 0.667 & 0.000 & -1.000 & -0.300 & -0.330 & $\mathrm{~N} / \mathrm{A}$ & $\mathrm{N} / \mathrm{A}$ \\
\hline 323453862 & 71360 & Ubiquitin-protein ligase & 0.333 & 0.667 & 0.000 & -0.470 & -0.300 & -0.610 & $\mathrm{~N} / \mathrm{A}$ & $\mathrm{N} / \mathrm{A}$ \\
\hline 323450178 & 65936 & Ankyrin & 1.000 & 0.000 & 0.000 & -0.100 & -1.000 & -0.076 & $\mathrm{~N} / \mathrm{A}$ & $\mathrm{N} / \mathrm{A}$ \\
\hline 323448917 & 31918 & Eukaryotic initiation factor 3 & 0.333 & 0.667 & 0.000 & -0.470 & -0.300 & -0.610 & $\mathrm{~N} / \mathrm{A}$ & $\mathrm{N} / \mathrm{A}$ \\
\hline 323455074 & 71075 & Hypothetical protein & 1.000 & 0.000 & 0.000 & -0.100 & -1.000 & -0.076 & $\mathrm{~N} / \mathrm{A}$ & $\mathrm{N} / \mathrm{A}$ \\
\hline 323451194 & 3292 & $\mathrm{ABC}$ transporter & 0.000 & 0.667 & 0.333 & -0.530 & -0.570 & -0.330 & 0.000 & 2.000 \\
\hline 323452072 & 26912 & $\begin{array}{l}\text { ATP-dependent RNA helicase } \\
\text { DBP3 }\end{array}$ & 0.000 & 0.667 & 0.333 & -0.530 & -0.570 & -0.330 & 0.000 & 2.000 \\
\hline 323455685 & 61839 & $\begin{array}{l}\text { Pyridoxamine 5'-phosphate } \\
\text { oxidase-related }\end{array}$ & 0.333 & 0.667 & 0.000 & -0.470 & -0.300 & -0.610 & $\mathrm{~N} / \mathrm{A}$ & $\mathrm{N} / \mathrm{A}$ \\
\hline 323452968 & 63783 & Hypothetical protein & 0.000 & 0.000 & 1.000 & -0.150 & -0.094 & -1.000 & 0.000 & 0.000 \\
\hline 323453349 & 71468 & Hypothetical protein & 0.000 & 0.333 & 0.667 & -0.280 & -0.430 & -0.580 & 0.000 & 0.500 \\
\hline 323455818 & 69665 & Ras small GTPase & 0.000 & 1.333 & 0.000 & -0.220 & -0.048 & -0.370 & $\mathrm{~N} / \mathrm{A}$ & $\mathrm{N} / \mathrm{A}$ \\
\hline 323451436 & 65013 & Ubiquitin thioesterase & 0.667 & 0.333 & 0.000 & -0.220 & -0.550 & -0.390 & $\mathrm{~N} / \mathrm{A}$ & $\mathrm{N} / \mathrm{A}$ \\
\hline 323457189 & 52028 & \begin{tabular}{|l|} 
Vacular sorting protein \\
\end{tabular} & 0.000 & 1.000 & 0.000 & -1.000 & -0.160 & -0.190 & $\mathrm{~N} / \mathrm{A}$ & $\mathrm{N} / \mathrm{A}$ \\
\hline 323456269 & 70763 & $\begin{array}{l}\text { Peptidase } \mathrm{M} \text {, neutral zinc } \\
\text { metallopeptidases. zinc- } \\
\text { binding site }\end{array}$ & 0.000 & 0.000 & 0.667 & -0.280 & -0.210 & -1.000 & 0.000 & 0.000 \\
\hline 323450302 & 29630 & Acyl-CoA dehydrogenase & 0.000 & 0.667 & 0.000 & -1.000 & -0.300 & -0.330 & $\mathrm{~N} / \mathrm{A}$ & $\mathrm{N} / \mathrm{A}$ \\
\hline 323457348 & 35763 & $\begin{array}{l}\mathrm{S} / \mathrm{T} \text { protein phosphatase } \\
\text { and/or metallophosphoesterase }\end{array}$ & 0.000 & 0.000 & 0.667 & -0.280 & -0.210 & -1.000 & 0.000 & 0.000 \\
\hline 242620052 & & 50 S ribosomal protein L24 & 0.000 & 0.000 & 0.667 & -0.280 & -0.210 & -1.000 & 0.000 & 0.000 \\
\hline 242620048 & & 30 S ribosomal protein S3 & 0.000 & 0.667 & 0.000 & -1.000 & -0.300 & -0.330 & $\mathrm{~N} / \mathrm{A}$ & $\mathrm{N} / \mathrm{A}$ \\
\hline 323448907 & 66948 & Ion transport protein & 0.000 & 0.000 & 0.667 & -0.280 & -0.210 & -1.000 & 0.000 & 0.000 \\
\hline 323448957 & 66859 & Hypothetical protein & 0.667 & 0.000 & 0.000 & -0.220 & -1.000 & -0.180 & $\mathrm{~N} / \mathrm{A}$ & $\mathrm{N} / \mathrm{A}$ \\
\hline 323449154 & 66674 & Peptide synthetase & 0.667 & 0.000 & 0.000 & -0.220 & -1.000 & -0.180 & $\mathrm{~N} / \mathrm{A}$ & $\mathrm{N} / \mathrm{A}$ \\
\hline 323449633 & 30762 & $\begin{array}{l}\text { SNF2-related helicase, C- } \\
\text { terminal }\end{array}$ & 0.667 & 0.000 & 0.000 & -0.220 & -1.000 & -0.180 & $\mathrm{~N} / \mathrm{A}$ & $\mathrm{N} / \mathrm{A}$ \\
\hline 323449944 & 66042 & $\begin{array}{l}\text { Mucin-associated surface } \\
\text { protein (MASP) }\end{array}$ & 0.000 & 0.000 & 0.667 & -0.280 & -0.210 & -1.000 & 0.000 & 0.000 \\
\hline 323450897 & 28631 & $\mathrm{ABC}$ transporter & 0.667 & 0.000 & 0.000 & -0.220 & -1.000 & -0.180 & $\mathrm{~N} / \mathrm{A}$ & $\mathrm{N} / \mathrm{A}$ \\
\hline 323452907 & 71551 & $\mathrm{C} 2$ domain containing protein & 0.667 & 0.000 & 0.000 & -0.220 & -1.000 & -0.180 & $\mathrm{~N} / \mathrm{A}$ & $\mathrm{N} / \mathrm{A}$ \\
\hline 323453109 & 37286 & Cysteinyl-tRNA synthetase & 0.667 & 0.000 & 0.000 & -0.220 & -1.000 & -0.180 & $\mathrm{~N} / \mathrm{A}$ & $\mathrm{N} / \mathrm{A}$ \\
\hline 323454275 & 62732 & Hypothetical protein & 0.667 & 0.000 & 0.000 & -0.220 & -1.000 & -0.180 & $\mathrm{~N} / \mathrm{A}$ & $\mathrm{N} / \mathrm{A}$ \\
\hline 323454523 & 58835 & DNA primase & 0.667 & 0.000 & 0.000 & -0.220 & -1.000 & -0.180 & N/A & $\mathrm{N} / \mathrm{A}$ \\
\hline
\end{tabular}

'N/A means that the control condition had a value of zero and a fold-change could not be calculated. 
Table S2) Proteins separated by cluster. Proteins listed in order of how they appear in Figure 2 from top to bottom.

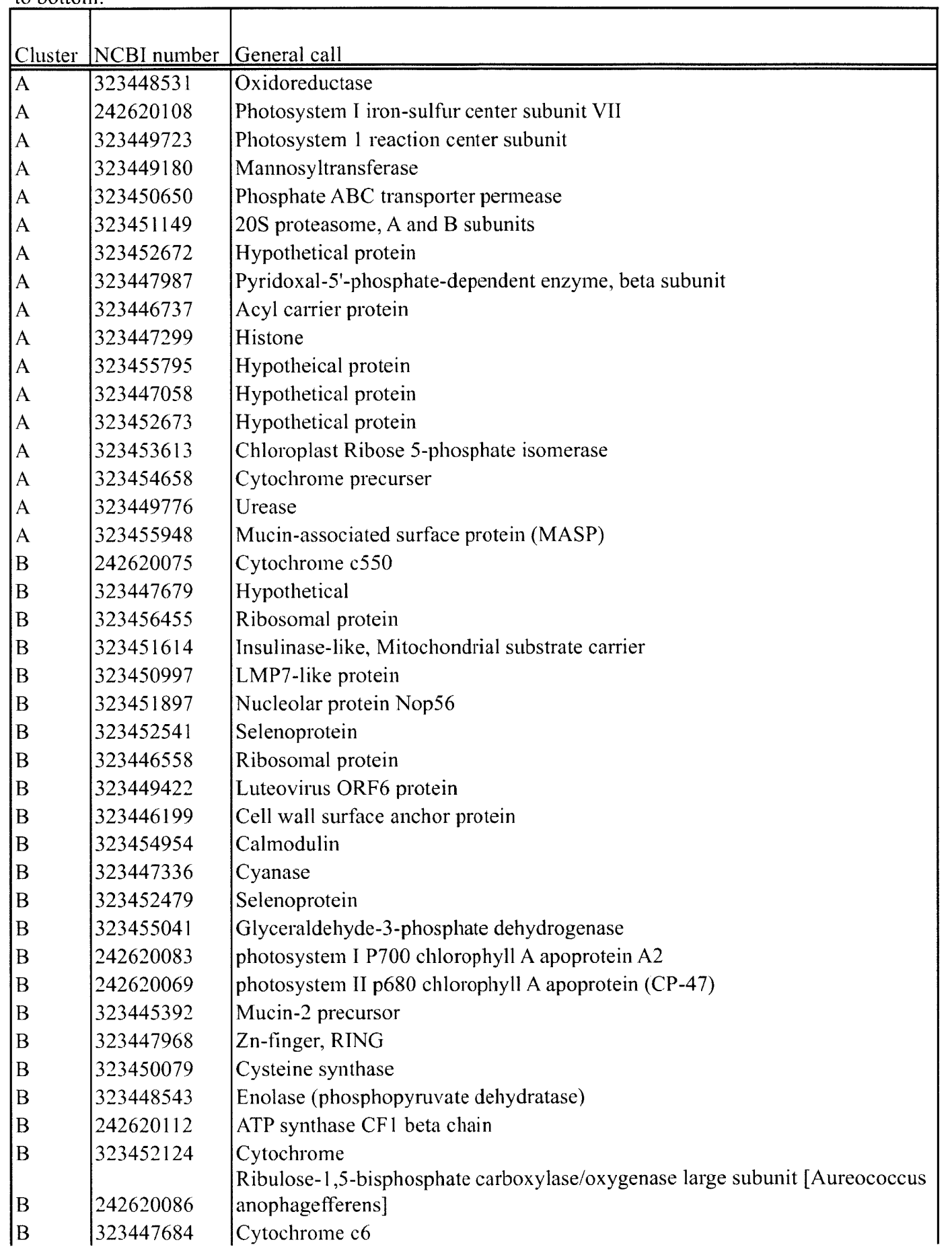




\begin{tabular}{|c|c|c|}
\hline B & 323456364 & Histone \\
\hline $\mathrm{B}$ & 323453682 & Hypothetical protein \\
\hline B & 323449583 & Ribosomal protein \\
\hline B & 323445193 & Histone \\
\hline B & 242620087 & Ribulose bisphosphate carboxlyase small chain \\
\hline B & 323451650 & Chloroplast hydroxymethylbilane synthase \\
\hline $\mathrm{B}$ & 323451867 & Selenoprotein \\
\hline B & 323451587 & Ribosomal Protein \\
\hline B & 323452812 & Dihydrolipoamide dehydrogenase \\
\hline B & 323456630 & Heparan Sulfate 2-0-sulfotranserase \\
\hline B & 323454341 & Thioredoxin domain 2 \\
\hline B & 323450925 & Ribosomal protein \\
\hline B & 323448060 & Ribosomal protein \\
\hline B & 323452552 & Proteasome \\
\hline B & 242620051 & $50 \mathrm{~S}$ ribosomal protein $\mathrm{L} 14$ \\
\hline B & 323454406 & Armet super family domain \\
\hline B & 323452815 & Ribosomal protein L4/L1e \\
\hline B & 323451167 & Ribosomal porotein \\
\hline B & 323452189 & PT-repeat \\
\hline B & 323449769 & Ribosomal protein \\
\hline B & 323449160 & Proteasome \\
\hline B & 323445273 & Proteasome \\
\hline B & 323457195 & Ribosomal Protein \\
\hline B & 323451216 & Ribosomal protein \\
\hline B & 323456180 & Ribosomal protein L5 \\
\hline B & 242620082 & photosystem I P700 chlorophyll A apoprotein A I \\
\hline B & 323451387 & 20S proteasome, $\mathrm{A}$ and $\mathrm{B}$ subunits \\
\hline B & 323457240 & Ammonium transporter \\
\hline B & 323453642 & O-acetylhomoserine/O-acetylserine sulfhydrylase \\
\hline B & 323456600 & Ribosomal protein L30, L7, Peptidase \\
\hline B & 323447579 & Ribosomal protein \\
\hline B & 323448448 & Nonphototropic hypocotyl \\
\hline B & 242620055 & 50S ribosomal protein L6 \\
\hline B & 323450867 & Acetamidase/Formamidase \\
\hline $\mathrm{C}$ & 323453007 & Initiation factor \\
\hline C & 242620067 & elongation factor $\mathrm{Tu}$ \\
\hline $\mathrm{C}$ & 323451553 & Glutamine synthetase \\
\hline $\mathrm{C}$ & 323454637 & Chaperonin ATPase \\
\hline $\mathrm{C}$ & 323455818 & Ras small GTPase \\
\hline $\mathrm{C}$ & 323454310 & Adenosine kinase \\
\hline $\mathrm{C}$ & 323454894 & Formylglycineamide ribotide amidotransferase \\
\hline $\mathrm{C}$ & 323454033 & Triosephosphate isomerase \\
\hline $\mathrm{C}$ & 323452581 & Chaperonin \\
\hline $\mathrm{C}$ & 323451541 & Ras small GTPase \\
\hline $\mathrm{D}$ & 323451419 & Citrate synthase \\
\hline $\mathrm{D}$ & 323447741 & Nonaspanin \\
\hline $\mathrm{D}$ & 242620028 & $30 \mathrm{~S}$ ribosomal protein $\mathrm{S} 2$ \\
\hline
\end{tabular}




\begin{tabular}{|c|c|c|}
\hline $\mathrm{D}$ & 323451948 & Ribosomal protein \\
\hline $\mathrm{D}$ & 323453433 & Nitrate reducatase \\
\hline $\mathrm{D}$ & 323448256 & Nitrate transporter \\
\hline $\mathrm{D}$ & 323454388 & Splicing factor \\
\hline $\mathrm{D}$ & 323453622 & Phosphoserine aminotransferase \\
\hline $\mathrm{D}$ & 323451767 & Hydroxyisobutyrate dehydrogenase \\
\hline $\mathrm{D}$ & 242620053 & 50 S ribosomal protein L5 \\
\hline $\mathrm{D}$ & 323453434 & Nitrite reductase \\
\hline $\mathrm{D}$ & 323457185 & Adaptin \\
\hline $\mathrm{D}$ & 323449674 & Peptidase \\
\hline $\mathrm{D}$ & 323450465 & Ribosomal protein L 18 \\
\hline $\mathrm{D}$ & 323455979 & ATPase \\
\hline $\mathrm{D}$ & 323451117 & Ribosomal protein \\
\hline $\mathrm{D}$ & 323450214 & Ribosomal protein \\
\hline $\mathrm{D}$ & 323448815 & Ribosomal Protein \\
\hline $\mathrm{D}$ & 242620043 & 50 S ribosomal protein L3 \\
\hline $\mathrm{D}$ & 323448850 & Ribosomal protein \\
\hline $\mathrm{D}$ & 323453856 & Ribosomal protein L6E \\
\hline D & 323452746 & Ribosomal protein \\
\hline $\mathrm{D}$ & 323456525 & ATP synthase \\
\hline $\mathrm{D}$ & 242620044 & $50 \mathrm{~S}$ ribosomal protein $\mathrm{L} 23$ \\
\hline $\mathrm{D}$ & 323453262 & Serine/threonine-protein kinase \\
\hline $\mathrm{D}$ & 323450970 & Ribosomal protein \\
\hline $\mathrm{D}$ & 323454706 & Ribonucleoprotein complex subunit \\
\hline $\mathrm{D}$ & 323448873 & Ribosomal protein \\
\hline $\mathrm{D}$ & 323449333 & Ribosomal protein \\
\hline $\mathrm{D}$ & 323452337 & Phosphate $\mathrm{ABC}$ transporter \\
\hline $\mathrm{D}$ & 323446694 & Ribosomal protein \\
\hline $\mathrm{D}$ & 323451627 & $\mathrm{Na}+/ \mathrm{H}+$ antiporter $\mathrm{NhaA}$ \\
\hline D & 323448266 & Histone \\
\hline $\mathrm{D}$ & 242620095 & $30 \mathrm{~S}$ ribosomal protein $\mathrm{S} 4$ \\
\hline D & 323447782 & Histone \\
\hline D & 323450569 & Ribosomal protein \\
\hline $\mathrm{D}$ & 323452089 & IMP dehydrogenase/GMP reductase \\
\hline $\mathrm{D}$ & 323452301 & Ribosomal protein \\
\hline D & 242620034 & ATP synthase CF 1 alpha chain \\
\hline $\mathrm{D}$ & 323449640 & Ribosomal protein \\
\hline D & 323454360 & Ribosomal protein \\
\hline $\mathrm{D}$ & 323449038 & Peptidase \\
\hline $\mathrm{D}$ & 323454189 & Ribosomal protein \\
\hline $\mathrm{D}$ & 323451135 & Proteasome \\
\hline $\mathrm{D}$ & 323448884 & Proteasome \\
\hline D & 323456545 & Ribosomal protein \\
\hline $\mathrm{D}$ & 323455169 & Ribosomal protein \\
\hline $\mathrm{D}$ & 323453239 & Proliferating cell nuclear antigen, PCNA \\
\hline $\mathrm{D}$ & 323449899 & Ribosomal protein \\
\hline $\mathrm{D}$ & 323451317 & G-protein beta WD-40 repeat (Guanine nucleotide-binding protein) \\
\hline
\end{tabular}




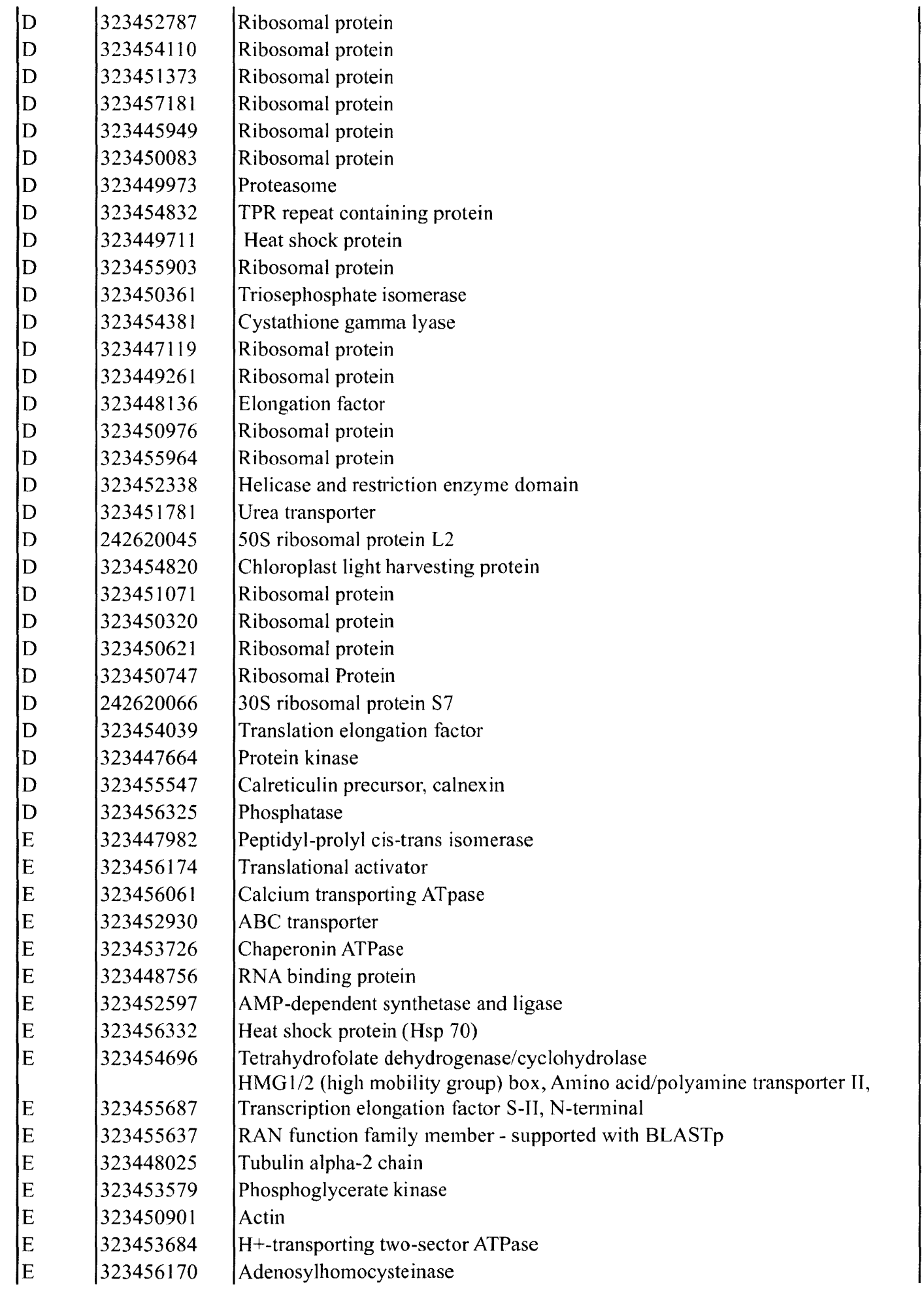


Sulfolipid biosynthesis protein

Hsp70-type chaperone

Co or Mg Chelatase

Glycine cleavage system

Hypothetical

Fructose bisphosphate aldolase

ATP synthase

Malate dehydrogenase

Aspartate/other aminotransferase

Chloroplast light harvesting protein

Pyruvate carboxylase

Glutamate synthase

Nucleoside diphosphate kinase

Triosephosphate isomerase

UDP-glucose 6-dehydrogenase

Chloroplast light harvesting protein

Pyruvate carboxylase

Glutamate-1-semialdehyde aminotransferase

Amino transferase class-I and II

Chloroplast light harvesting protein

S-adenosylmethionine synthetase

$\mathrm{ABC}$ transporter

Glyceraldehyde-3-phosphate dehydrogenase

Methionyl / Aminoacyl-tRNA synthetase

Hypothetical protein

Phospholipid/glycerol acyltransferase

Rieske protein (Iron sulfur protein)

Helicase

Carbamoyl-phosphate synthase

Inorganic pyrophosphatase

Hypothetical protein

Conserved hypothetical plastid protein Ycf39

Dynein heavy chain, AAA ATPase

Hypothetical protein

Epsilon 1-COP

Peptidase

Acetyl-coenzyme A synthetase

Myosin head, motor region

Chloroplast light harvesting protein

UTP--glucose-1-phosphate uridylyltransferase

Mitochondrial substrate carrier

Zinc-containing alcohol dehydrogenase superfamily

Calreticulin/calnexin

Enolase (phosphopyruvate dehydratase)

Inorganic phosphate transporter

ABC transporter

Nicotinamide nucleotide transhydrogenase 


\begin{tabular}{|c|c|c|}
\hline $\mathrm{F}$ & 323450268 & Flavin-containing monooxygenase-like \\
\hline $\mathrm{F}$ & 323456208 & Synaptobrevin \\
\hline $\mathrm{F}$ & 323446732 & Hypothetical protein \\
\hline $\mathrm{F}$ & 323452005 & Chloroplast light harvesting protein \\
\hline $\mathrm{F}$ & 323451260 & Cobalamin synthes is protein \\
\hline $\mathrm{F}$ & 323452273 & Hypotheical protein \\
\hline $\mathrm{F}$ & 323452383 & Ribose-phosphate pyrophosphokinase \\
\hline $\mathrm{F}$ & 323457207 & Chloroplast light harvesting protein \\
\hline $\mathrm{F}$ & 323454417 & Beta-ketoacyl ACP synthase \\
\hline F & 323456109 & ATPase \\
\hline $\mathrm{F}$ & 323455642 & 5'-nucleotidase \\
\hline $\mathrm{F}$ & 323453090 & Aconitate hydratase \\
\hline $\mathrm{F}$ & 323449755 & Amino transferase class-III \\
\hline $\mathrm{F}$ & 323450876 & Pyruvate kinase \\
\hline $\mathrm{F}$ & 323451378 & Sterol methyltransferase \\
\hline $\mathrm{F}$ & 323452833 & CAP protein \\
\hline $\mathrm{F}$ & 323448862 & $\begin{array}{l}\text { Carbamoyl-phosphate synthase, Carboxyl transferase, Biotin carboxylase, } \\
\text { Biotin/lipoyl attachment }\end{array}$ \\
\hline $\mathrm{F}$ & 323452848 & Phosphoglucomutase \\
\hline $\mathrm{F}$ & 323447335 & Formate/nitrite transporter \\
\hline $\mathrm{F}$ & 323452898 & Glutamate dehydrogenase \\
\hline $\mathrm{F}$ & 323454682 & GDP dissociation protein \\
\hline $\mathrm{F}$ & 323450582 & Transketolase \\
\hline $\mathrm{F}$ & 323454473 & Iron-dependent fumarate hydratase, $\mathrm{Fe}$-S type hydro-lyases tartrate/fumarate \\
\hline $\mathrm{F}$ & 323456351 & Chloroplast light harvesting protein \\
\hline $\mathrm{F}$ & 323455486 & Clathrin vesicle coat \\
\hline $\mathrm{F}$ & 323451977 & GDP-mannose 3,5-epimerase \\
\hline $\mathrm{F}$ & 323453524 & Glutathion transferase \\
\hline F & 323456872 & FAD linked oxidase, $N$-terminal \\
\hline $\mathrm{F}$ & 323456684 & 3-hydroxyacyl-CoA dehydrogenase \\
\hline $\mathrm{F}$ & 323448823 & Adenylylsulfate kinase \\
\hline $\mathrm{F}$ & 323455708 & Cell division protein $\mathrm{FtsH}$ \\
\hline $\mathrm{F}$ & 323448789 & GUN4 like domain \\
\hline $\mathrm{F}$ & 323454031 & Chloroplast light harvesting protein \\
\hline $\mathrm{F}$ & 323450235 & Ttubulin beta chain \\
\hline $\mathrm{F}$ & 323450497 & Serine/threonine-protein phosphatase \\
\hline $\mathrm{F}$ & 323453325 & Phosphoenolpyruvate carboxylase \\
\hline $\mathrm{F}$ & 323450177 & Ras small GTPase \\
\hline $\mathrm{F}$ & 323449109 & Low molecular weight phosphotyrosine protein phosphatase \\
\hline $\mathrm{F}$ & 323451061 & Histidine kinase \\
\hline $\mathrm{F}$ & 323453590 & ATPase \\
\hline $\mathrm{F}$ & 323456607 & Aminotransferase \\
\hline $\mathrm{F}$ & 323453164 & N-ethylmaleimide sensitive fusion protein \\
\hline $\mathrm{F}$ & 323450905 & Endonuclease/exonuclease/phosphatase \\
\hline $\mathrm{F}$ & 323449461 & Chloroplast light harvesting protein \\
\hline $\mathrm{F}$ & 323457297 & Myosin \\
\hline $\mathrm{F}$ & 323449672 & Chloroplast light harvesting protein \\
\hline
\end{tabular}




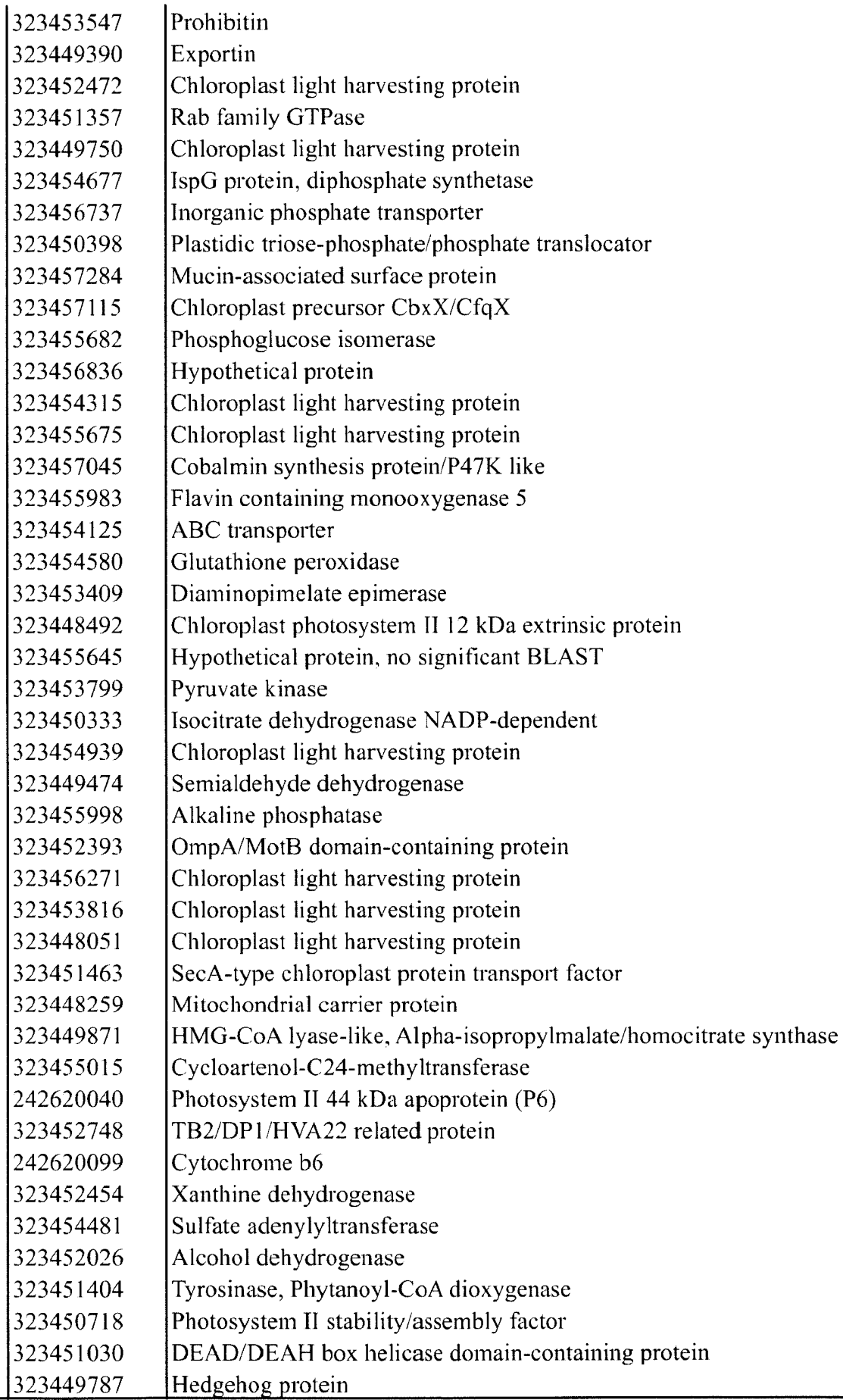


Table S3) Proteins and associated transcript data (SAGE tag counts).

\begin{tabular}{|c|c|c|c|c|c|c|c|}
\hline NCBI & General call & $\begin{array}{l}\text { Mean of } \\
\text { spectral }\end{array}$ & counts & $\begin{array}{l}\text { SAut lag } \\
\text { (normalize } \\
1: \text { in }\end{array}$ & do to & $\begin{array}{l}\text { Fold cha } \\
\text { to contr }\end{array}$ & inge relaive \\
\hline & & Control & $-\mathrm{P}$ & Control & $-\mathrm{P}$ & Protein & Transcript \\
\hline 323455041 & $\begin{array}{l}\text { Glyceraldehyde-3-phosphate } \\
\text { dehydrogenase }\end{array}$ & 138.33 & 61.67 & $5.62 \mathrm{E}-05$ & $4.09 \mathrm{E}-05$ & -2.24 & -1.37 \\
\hline 323447300 & Histone & 52.67 & 39.67 & $8.43 \mathrm{E}-05$ & $4.09 \mathrm{E}-05$ & -1.33 & -2.06 \\
\hline 323453579 & Phosphoglycerate kinase & 27.00 & 37.67 & $5.62 \mathrm{E}-05$ & $4.09 \mathrm{E}-05$ & 1.40 & -1.37 \\
\hline 323456332 & Heat shock protein (Hsp 70) & 19.67 & 25.00 & $5.62 \mathrm{E}-05$ & $4.09 \mathrm{E}-05$ & 1.27 & -1.37 \\
\hline 323454637 & Chaperonin ATPase & 19.67 & 19.00 & $1.15 \mathrm{E}-03$ & $2.13 \mathrm{E}-03$ & -1.04 & 1.85 \\
\hline 323448984 & Ferredoxin NADP reductase & 22.67 & 21.67 & $2.81 \mathrm{E}-05$ & $4.09 \mathrm{E}-05$ & -1.05 & 1.46 \\
\hline 323457021 & Hypothetical & 16.33 & 21.00 & $8.43 \mathrm{E}-05$ & $8.18 \mathrm{E}-05$ & 1.29 & -1.03 \\
\hline 323456989 & $\begin{array}{l}\text { Fructose bisphosphate } \\
\text { aldolase }\end{array}$ & 18.00 & 16.00 & $5.34 \mathrm{E}-04$ & $1.64 \mathrm{E}-04$ & -1.13 & -3.26 \\
\hline 323449461 & $\begin{array}{l}\text { Chloroplast light harvesting } \\
\text { protein }\end{array}$ & 12.00 & 24.00 & $3.94 E-04$ & $4.91 \mathrm{E}-04$ & 2.00 & 1.25 \\
\hline 323450901 & Actin & 10.67 & 17.67 & $2.81 \mathrm{E}-05$ & $8.18 \mathrm{E}-05$ & 1.66 & 2.91 \\
\hline 323455179 & $\begin{array}{l}\text { Peptidyl-prolyl cis-trans } \\
\text { isomerase }\end{array}$ & 14.00 & 15.67 & $2.81 \mathrm{E}-03$ & $1.64 \mathrm{E}-03$ & 1.12 & -1.72 \\
\hline 323455979 & ATPase & 17.67 & 5.33 & $1.12 \mathrm{E}-04$ & $1.23 \mathrm{E}-04$ & -3.31 & 1.09 \\
\hline 323455486 & Clathrin vesicle coat & 1.00 & 16.67 & $4.22 \mathrm{E}-04$ & $9.41 \mathrm{E}-04$ & 16.67 & 2.23 \\
\hline 323452189 & $\begin{array}{l}\text { PT-repeat } \\
\text { HMG1/2 (high mobility } \\
\text { group) box, Amino }\end{array}$ & 17.33 & 8.33 & $1.12 \mathrm{E}-04$ & $4.09 \mathrm{E}-04$ & -2.08 & 3.64 \\
\hline 323455687 & $\begin{array}{l}\text { acid/polyamine transporter II, } \\
\text { Transcription elongation } \\
\text { factor S-II, N-terminal }\end{array}$ & 7.00 & 11.00 & 3.37E-04 & $3.27 \mathrm{E}-04$ & 1.57 & -1.03 \\
\hline 323447336 & Cyanase & 18.00 & 9.67 & $1.97 \mathrm{E}-04$ & 4.91E-04 & -1.86 & 2.50 \\
\hline 323454769 & $\begin{array}{l}\text { Nucleoside diphosphate } \\
\text { kinase }\end{array}$ & 8.67 & 13.67 & $2.81 \mathrm{E}-04$ & $1.39 \mathrm{E}-03$ & 1.58 & 4.95 \\
\hline 323454760 & $\begin{array}{l}\text { Inorganic phosphate } \\
\text { transporter }\end{array}$ & 0.33 & 19.67 & $3.94 \mathrm{E}-04$ & $2.25 \mathrm{E}-03$ & 59.00 & 5.72 \\
\hline 323449723 & $\begin{array}{l}\text { Photosystem } 1 \text { reaction center } \\
\text { subunit }\end{array}$ & 14.00 & 14.00 & $8.43 \mathrm{E}-05$ & $8.18 \mathrm{E}-05$ & -1.00 & -1.03 \\
\hline 323448531 & Oxidoreductase & 13.33 & 15.33 & $8.43 E-05$ & 4.09E-05 & 1.15 & -2.06 \\
\hline 323454939 & $\begin{array}{l}\text { Chloroplast light harvesting } \\
\text { protein }\end{array}$ & 9.33 & 14.67 & $8.43 \mathrm{E}-05$ & 4.09E-04 & 1.57 & 4.85 \\
\hline 323448051 & $\begin{array}{l}\text { Chloroplast light harvesting } \\
\text { protein }\end{array}$ & 8.00 & 13.00 & $2.81 \mathrm{E}-05$ & $8.18 \mathrm{E}-05$ & 1.63 & 2.91 \\
\hline 323453090 & Aconitate hydratase & 5.33 & 12.67 & $1.12 \mathrm{E}-04$ & $4.09 \mathrm{E}-05$ & 2.38 & -2.75 \\
\hline 323446473 & Expressed protein & 13.00 & 8.67 & $1.12 \mathrm{E}-04$ & 4.09E-04 & -1.50 & 3.64 \\
\hline 323447782 & $\begin{array}{l}\text { Histone } \\
\text { Rieske protein (Iron sulfur }\end{array}$ & 9.00 & 4.33 & $6.18 \mathrm{E}-04$ & $8.18 \mathrm{E}-04$ & -2.08 & 1.32 \\
\hline 323451957 & $\begin{array}{l}\text { protein), Chloroplast light } \\
\text { harvesting protein } \\
\text { G-protein beta WD- } 40 \text { repeat }\end{array}$ & 7.67 & 7.33 & $3.37 \mathrm{E}-04$ & $6.14 \mathrm{E}-04$ & -1.05 & 1.82 \\
\hline 323451317 & $\begin{array}{l}\text { (Guanine nucleotide-binding } \\
\text { protein) }\end{array}$ & 15.67 & 1.33 & $2.53 E-04$ & $8.18 \mathrm{E}-05$ & -11.75 & -3.09 \\
\hline
\end{tabular}




\begin{tabular}{|c|c|c|c|c|c|c|c|}
\hline 323453907 & $\begin{array}{l}\text { Enolase (phosphopyruvate } \\
\text { dehydratase) }\end{array}$ & 7.33 & 10.67 & $1.97 \mathrm{E}-04$ & $2.86 \mathrm{E}-04$ & 1.45 & 1.46 \\
\hline 323453726 & Chaperonin ATPase & 5.67 & 8.00 & $2.81 \mathrm{E}-05$ & $4.09 \mathrm{E}-05$ & 1.41 & 1.46 \\
\hline 323455658 & Oxygen-evolving enhancer 1 & 7.00 & 9.33 & $2.81 \mathrm{E}-05$ & $4.09 \mathrm{E}-05$ & 1.33 & 1.46 \\
\hline 323453500 & ADP-ribosylation factor & 9.00 & 7.67 & $9.56 \mathrm{E}-04$ & $4.91 \mathrm{E}-04$ & -1.17 & -1.95 \\
\hline 323450172 & Peptidase & 7.67 & 6.00 & $1.97 \mathrm{E}-04$ & 2.05E-04 & -1.28 & 1.04 \\
\hline 323453642 & $\begin{array}{l}\text { O-acetylhomoserine/O- } \\
\text { acetylserine sulfhydrylase }\end{array}$ & 12.67 & 5.00 & $5.62 \mathrm{E}-05$ & 4.09E-05 & -2.53 & -1.37 \\
\hline 323450799 & $\begin{array}{l}\text { Kringle, PT-repeat, } \\
\text { Serine/threonine dehydratase }\end{array}$ & 10.33 & 6.00 & $2.81 \mathrm{E}-05$ & $4.09 \mathrm{E}-05$ & -1.72 & 1.46 \\
\hline 323452158 & $\begin{array}{l}\text { Chloroplast light harvesting } \\
\text { protein }\end{array}$ & 4.00 & 9.33 & $9.56 \mathrm{E}-04$ & $4.91 \mathrm{E}-04$ & 2.33 & -1.95 \\
\hline 323445392 & Mucin-2 precursor & 13.33 & 6.33 & $4.22 \mathrm{E}-04$ & $6.55 \mathrm{E}-04$ & -2.11 & 1.55 \\
\hline 323454246 & $\begin{array}{l}\text { UDP-glucose 6- } \\
\text { dehydrogenase }\end{array}$ & 2.33 & 8.33 & $8.43 \mathrm{E}-05$ & $1.23 \mathrm{E}-04$ & 3.57 & 1.46 \\
\hline 323456872 & $\begin{array}{l}\text { FAD linked oxidase, } \mathrm{N}- \\
\text { terminal }\end{array}$ & 2.00 & 10.33 & $1.69 \mathrm{E}-04$ & $3.68 \mathrm{E}-04$ & 5.17 & 2.18 \\
\hline 323454481 & Sulfate adenylyltransferase & 5.67 & 13.00 & $8.43 \mathrm{E}-05$ & $4.09 \mathrm{E}-05$ & 2.29 & -2.06 \\
\hline 323457207 & $\begin{array}{l}\text { Chloroplast light harvesting } \\
\text { protein }\end{array}$ & 5.33 & 10.00 & $5.62 \mathrm{E}-05$ & $3.27 \mathrm{E}-04$ & 1.88 & 5.82 \\
\hline 323451419 & Citrate synthase & 7.33 & 3.33 & $2.81 \mathrm{E}-05$ & $4.09 \mathrm{E}-05$ & -2.20 & 1.46 \\
\hline 323446545 & $\begin{array}{l}\text { Chloroplast light harvesting } \\
\text { protein }\end{array}$ & 12.33 & 10.00 & $1.41 \mathrm{E}-04$ & $2.05 \mathrm{E}-04$ & -1.23 & 1.46 \\
\hline 323447358 & $\begin{array}{l}\text { Chloroplast light harvesting } \\
\text { protein }\end{array}$ & 7.67 & 5.33 & $1.41 \mathrm{E}-04$ & $2.05 \mathrm{E}-04$ & -1.44 & 1.46 \\
\hline 323454334 & $\begin{array}{l}\text { Chloroplast light harvesting } \\
\text { protein }\end{array}$ & 6.00 & 7.67 & $2.53 \mathrm{E}-04$ & $2.86 \mathrm{E}-04$ & 1.28 & 1.13 \\
\hline 323447744 & $\begin{array}{l}\text { Chloroplast light harvesting } \\
\text { protein }\end{array}$ & 6.33 & 7.67 & $8.43 \mathrm{E}-05$ & $1.23 \mathrm{E}-04$ & 1.21 & 1.46 \\
\hline 323450268 & $\begin{array}{l}\text { Flavin-containing } \\
\text { monooxygenase-like }\end{array}$ & 0.33 & 12.33 & $5.90 \mathrm{E}-04$ & $1.84 \mathrm{E}-03$ & 37.00 & 3.12 \\
\hline 323455568 & $\begin{array}{l}\text { Chloroplast light harvesting } \\
\text { protein }\end{array}$ & 6.33 & 8.00 & $3.09 \mathrm{E}-04$ & $4.91 \mathrm{E}-04$ & 1.26 & 1.59 \\
\hline 323455382 & $\begin{array}{l}\text { Dynein heavy chain, AAA } \\
\text { ATPase }\end{array}$ & 4.33 & 7.33 & $1.41 \mathrm{E}-04$ & $2.86 \mathrm{E}-04$ & 1.69 & 2.04 \\
\hline 323454019 & $\begin{array}{l}\text { Chloroplast light harvesting } \\
\text { protein }\end{array}$ & 5.33 & 6.33 & $2.53 \mathrm{E}-04$ & $1.10 \mathrm{E}-03$ & 1.19 & 4.37 \\
\hline 323453856 & Ribosomal protein L6E & 10.00 & 1.67 & $1.69 \mathrm{E}-04$ & 4.09E-05 & -6.00 & -4.12 \\
\hline 323456180 & Ribosomal protein L5 & 14.00 & 2.33 & $4.22 \mathrm{E}-04$ & $4.91 \mathrm{E}-04$ & -6.00 & 1.16 \\
\hline 323453541 & Pyruvate kinase & 5.67 & 6.33 & $2.81 \mathrm{E}-05$ & $1.23 \mathrm{E}-04$ & 1.12 & 4.37 \\
\hline 323452454 & Xanthine dehydrogenase & 5.67 & 11.00 & $8.43 \mathrm{E}-05$ & $4.09 \mathrm{E}-05$ & 1.94 & -2.06 \\
\hline 323450616 & Pyruvate carboxylase & 2.67 & 7.67 & $5.62 \mathrm{E}-05$ & 4.09E-05 & 2.87 & -1.37 \\
\hline 323450905 & $\begin{array}{l}\text { Endonuclease/exonuclease/ph } \\
\text { osphatase }\end{array}$ & 2.67 & 11.00 & $5.62 \mathrm{E}-05$ & 4.09E-05 & 4.12 & -1.37 \\
\hline 323452472 & $\begin{array}{l}\text { Chloroplast light harvesting } \\
\text { protein }\end{array}$ & 4.00 & 10.33 & $5.62 \mathrm{E}-05$ & $3.68 \mathrm{E}-04$ & 2.58 & 6.55 \\
\hline 323454267 & Inositol phosphatase & 5.33 & 7.33 & $5.62 \mathrm{E}-05$ & $4.09 \mathrm{E}-05$ & 1.38 & -1.37 \\
\hline 323456271 & $\begin{array}{l}\text { Chloroplast light harvesting } \\
\text { protein }\end{array}$ & 4.00 & 10.00 & $1.12 \mathrm{E}-04$ & $1.23 \mathrm{E}-04$ & 2.50 & 1.09 \\
\hline 323449755 & Amino transferase class-III & 0.33 & 10.00 & 1.69E-04 & $5.32 \mathrm{E}-04$ & 30.00 & 3.15 \\
\hline
\end{tabular}




\begin{tabular}{|c|c|c|c|c|c|c|c|}
\hline 323454635 & $\begin{array}{l}\text { Chloroplast 3-oxoacyl-[acyl- } \\
\text { carrier protein] reductase } \\
\text { orecursor }\end{array}$ & 7.33 & 4.67 & $8.43 \mathrm{E}-05$ & $4.09 \mathrm{E}-05$ & -1.57 & -2.06 \\
\hline 323449750 & $\begin{array}{l}\text { Chloroplast light harvesting } \\
\text { protein }\end{array}$ & 4.67 & 8.33 & $1.41 \mathrm{E}-04$ & $2.45 \mathrm{E}-04$ & 1.79 & 1.75 \\
\hline 323454622 & Ubiquitin & 8.33 & 4.33 & $2.25 \mathrm{E}-04$ & $8.18 \mathrm{E}-05$ & -1.92 & -2.75 \\
\hline 323452479 & Selenoprotein & 8.33 & 5.33 & $8.43 \mathrm{E}-04$ & $1.19 \mathrm{E}-03$ & -1.56 & 1.41 \\
\hline 323453956 & $\begin{array}{l}\text { Chloroplast light harvesting } \\
\text { protein }\end{array}$ & 4.67 & 6.00 & $1.35 \mathrm{E}-03$ & $1.55 \mathrm{E}-03$ & 1.29 & 1.15 \\
\hline 323451749 & $\begin{array}{l}\text { Calcium-binding EF-hand, } \\
\text { Pleckstrin-like, LMBR l-like } \\
\text { conserved region }\end{array}$ & 6.00 & 6.33 & $2.81 \mathrm{E}-05$ & $4.09 \mathrm{E}-05$ & 1.06 & 1.46 \\
\hline 323450447 & $\begin{array}{l}\text { Chloroplast light harvesting } \\
\text { protein }\end{array}$ & 5.33 & 6.33 & $5.62 \mathrm{E}-05$ & $8.18 \mathrm{E}-05$ & 1.19 & 1.46 \\
\hline 323455169 & Ribosomal protein & 9.33 & 0.67 & $1.43 \mathrm{E}-03$ & $6.14 \mathrm{E}-04$ & -14.00 & -2.34 \\
\hline 323450465 & Ribosomal protein L18 & 7.00 & 1.67 & $8.43 \mathrm{E}-05$ & $1.23 \mathrm{E}-04$ & -4.20 & 1.46 \\
\hline 323457181 & Ribosomal protein & 9.67 & 0.33 & $3.09 \mathrm{E}-04$ & $2.45 \mathrm{E}-04$ & -29.00 & -1.26 \\
\hline 323450876 & Pyruvate kinase & 1.00 & 7.67 & $5.62 \mathrm{E}-05$ & $8.18 \mathrm{E}-05$ & 7.67 & 1.46 \\
\hline 323451948 & Ribosomal protein & 5.67 & 3.00 & $2.81 \mathrm{E}-05$ & $8.18 \mathrm{E}-05$ & -1.89 & 2.91 \\
\hline 323454655 & $\begin{array}{l}\text { Chloroplast light harvesting } \\
\text { protein }\end{array}$ & 4.00 & 6.00 & $1.12 \mathrm{E}-04$ & $2.05 \mathrm{E}-04$ & 1.50 & 1.82 \\
\hline 323454039 & Translation elongation factor & 6.67 & 2.67 & $9.56 \mathrm{E}-04$ & $4.09 \mathrm{E}-04$ & -2.50 & -2.34 \\
\hline 323450925 & Ribosomal protein & 8.33 & 1.00 & $1.41 \mathrm{E}-03$ & $8.59 \mathrm{E}-04$ & -8.33 & -1.64 \\
\hline 323450518 & $\begin{array}{l}\text { Rieske protein (Iron sulfur } \\
\text { protein) }\end{array}$ & 2.33 & 6.00 & $3.65 \mathrm{E}-04$ & $1.64 \mathrm{E}-04$ & 2.57 & -2.23 \\
\hline 323451117 & Ribosomal protein & 6.00 & 2.00 & $1.88 \mathrm{E}-03$ & $1.02 \mathrm{E}-03$ & -3.00 & -1.84 \\
\hline 323447987 & $\begin{array}{l}\text { Pyridoxal-5'-phosphate- } \\
\text { dependent enzyme, beta } \\
\text { subunit }\end{array}$ & 6.67 & 4.67 & $2.81 \mathrm{E}-05$ & $8.18 \mathrm{E}-05$ & -1.43 & 2.91 \\
\hline 323453146 & $\begin{array}{l}\text { Chloroplast light harvesting } \\
\text { protein }\end{array}$ & 5.67 & 5.33 & $2.81 \mathrm{E}-05$ & $1.23 \mathrm{E}-04$ & -1.06 & 4.37 \\
\hline 323456741 & $\begin{array}{l}\text { Mitochondrial substrate } \\
\text { carrier }\end{array}$ & 0.67 & 6.00 & $1.69 \mathrm{E}-04$ & $2.86 \mathrm{E}-04$ & 9.00 & 1.70 \\
\hline 323455317 & Inorganic pyrophosphatase & 4.33 & 5.33 & $1.12 \mathrm{E}-04$ & 4.09E-05 & 1.23 & -2.75 \\
\hline 323449640 & Ribosomal protein & 6.33 & 1.00 & $3.09 \mathrm{E}-04$ & $2.45 \mathrm{E}-04$ & -6.33 & -1.26 \\
\hline 323456110 & Pyruvate carboxylase & 1.67 & 4.33 & $2.81 \mathrm{E}-05$ & 4.09E-05 & 2.60 & 1.46 \\
\hline 323455642 & 5 '-nucleotidase & 0.33 & 6.00 & $3.65 \mathrm{E}-04$ & $2.41 \mathrm{E}-03$ & 18.00 & 6.61 \\
\hline 323453007 & Initiation factor & 3.33 & 2.33 & $1.41 \mathrm{E}-04$ & $4.09 \mathrm{E}-05$ & -1.43 & -3.43 \\
\hline 323453325 & $\begin{array}{l}\text { Phosphoenolpyruvate } \\
\text { carboxylase }\end{array}$ & 0.67 & 5.33 & $5.62 \mathrm{E}-05$ & 4.09E-05 & 8.00 & -1.37 \\
\hline 323450330 & $\mathrm{ABC}$ transporter & 0.33 & 7.00 & $1.97 \mathrm{E}-04$ & $2.45 \mathrm{E}-04$ & 21.00 & 1.25 \\
\hline 323456061 & Calcium transporting ATpase & 1.67 & 2.67 & $5.34 \mathrm{E}-04$ & $9.00 \mathrm{E}-04$ & 1.60 & 1.69 \\
\hline 323455294 & ABC transporter & 1.00 & 4.00 & 1.12E-04 & $6.96 \mathrm{E}-04$ & 4.00 & 6.19 \\
\hline 323448025 & Tubulin alpha- 2 chain & 1.00 & 3.67 & $1.97 \mathrm{E}-04$ & $1.23 \mathrm{E}-04$ & 3.67 & -1.60 \\
\hline 323455059 & $\begin{array}{l}\text { Dihydrolipoamide S- } \\
\text { acetyltransferase }\end{array}$ & 3.33 & 4.33 & $1.41 \mathrm{E}-04$ & $4.09 \mathrm{E}-05$ & 1.30 & -3.43 \\
\hline 323447119 & Ribosomal protein & 5.33 & 0.33 & $5.62 \mathrm{E}-04$ & $4.50 \mathrm{E}-04$ & -16.00 & -1.25 \\
\hline 323447711 & Heat shock protein Hsp90 & 3.33 & 4.00 & $2.81 \mathrm{E}-04$ & $8.18 \mathrm{E}-05$ & 1.20 & -3.43 \\
\hline 323454985 & Histidinol dehydrogenase & 4.33 & 2.33 & $2.25 \mathrm{E}-04$ & $8.18 \mathrm{E}-05$ & -1.86 & -2.75 \\
\hline
\end{tabular}




\begin{tabular}{|c|c|c|c|c|c|c|c|}
\hline 323450867 & Acetamidase/Formamidase & 5.67 & 2.00 & 1.97E-04 & $4.09 \mathrm{E}-05$ & -2.83 & -4.81 \\
\hline 323457045 & $\begin{array}{l}\text { Cobalmin synthesis } \\
\text { protein/P47K like }\end{array}$ & 1.33 & 4.67 & $5.90 \mathrm{E}-04$ & $5.73 \mathrm{E}-04$ & 3.50 & -1.03 \\
\hline 23451977 & GDP-mannose 3,5-epimerase & 0.33 & 4.33 & $3.37 \mathrm{E}-04$ & $6.96 \mathrm{E}-04$ & 13.00 & 2.06 \\
\hline 23452597 & $\begin{array}{l}\text { AMP-dependent synthetase } \\
\text { and ligase }\end{array}$ & 2.00 & 3.00 & $5.62 \mathrm{E}-05$ & $4.09 \mathrm{E}-05$ & 1.50 & -1.37 \\
\hline 323450333 & $\begin{array}{l}\text { Isocitrate dehydrogenase } \\
\text { NADP-dependent }\end{array}$ & 1.33 & 7.00 & $3.94 \mathrm{E}-04$ & $2.45 \mathrm{E}-04$ & 5.25 & -1.60 \\
\hline 323452437 & $\begin{array}{l}\text { Dihydrolipoamide } \\
\text { dehydrogenase }\end{array}$ & 3.67 & 3.00 & $3.94 \mathrm{E}-04$ & $6.14 \mathrm{E}-04$ & -1.22 & 1.56 \\
\hline 23448256 & Nitrate transporter & 1.33 & 0.33 & 3.37E-04 & 4.09E-05 & -4.00 & -8.24 \\
\hline 23455645 & $\begin{array}{l}\text { thetical protein, no } \\
\text { ficant BLAST }\end{array}$ & 2.33 & 5.67 & $2.25 \mathrm{E}-04$ & $3.68 \mathrm{E}-04$ & 2.43 & 1.64 \\
\hline 323454364 & $\begin{array}{l}\text { Serine } \\
\text { hydroxymethyltransferase }\end{array}$ & 1.67 & 3.00 & $1.41 \mathrm{E}-04$ & $8.18 \mathrm{E}-05$ & 1.80 & -1.72 \\
\hline 453341 & Tryptophan synthase & 2.33 & 3.00 & $5.62 \mathrm{E}-05$ & 4.09E-05 & 1.29 & -1.37 \\
\hline 48626 & Elor & 2.33 & 2.67 & $3 E-04$ & $6.14 \mathrm{E}-04$ & 1.14 & -1.01 \\
\hline 456516 & Enoyl & 2.00 & 3.33 & $97 \mathrm{E}-04$ & $4.09 \mathrm{E}-05$ & 1.67 & -4.81 \\
\hline 23449254 & $\begin{array}{l}\text { Carbamoyl-phosphate } \\
\text { synthase }\end{array}$ & & 2.00 & $2.81 \mathrm{E}-05$ & $1.23 \mathrm{E}-04$ & 1.20 & 4.37 \\
\hline 448815 & Ribosomal Protein & 7.00 & 0.33 & $3 \mathrm{E}-05$ & $8.18 \mathrm{E}-05$ & -21.00 & -1.03 \\
\hline 1587 & Rib & 6.67 & 0.33 & $7 \mathrm{E}-04$ & $1.64 \mathrm{E}-04$ & -20.00 & -2.06 \\
\hline 446694 & Ribc & 3.67 & 1.00 & $5.90 \mathrm{E}-04$ & $3.68 \mathrm{E}-04$ & -3.67 & -1.60 \\
\hline 323455547 & lin precursor, & & 1.00 & $2.81 \mathrm{E}-05$ & $1.23 \mathrm{E}-04$ & -4.00 & 4.37 \\
\hline 50079 & synthase & 4.67 & 1.67 & $5 E-04$ & $1.23 \mathrm{E}-04$ & -2.80 & \\
\hline & isomerase & & & & -05 & & \\
\hline 1116 & Alip & 3.67 & 2.33 & -04 & $E-04$ & -1.57 & -1.37 \\
\hline 409 & te epimerase & 1.00 & 4.67 & $7 \mathrm{E}-04$ & -04 & 4.67 & -1.65 \\
\hline 3165 & Ras & & 3.00 & 9E-04 & -04 & & \\
\hline & & & & E-04 & $8.18 \mathrm{E}-05$ & -5.50 & -4.12 \\
\hline 323454382 & $20 \mathrm{~S}$ & 2.67 & 1.67 & $6.46 \mathrm{E}-04$ & $5.32 \mathrm{E}-04$ & -1.60 & -1.22 \\
\hline 323450585 & $\begin{array}{l}\text { Phosphoglycerate/bisphospho } \\
\text { glycerate mutase }\end{array}$ & 2.33 & 2.67 & $1.69 \mathrm{E}-04$ & $1.23 \mathrm{E}-04$ & 1.14 & -1.37 \\
\hline 323456684 & yl-CoA & 0.33 & 3.00 & $1.12 \mathrm{E}-04$ & $4.09 \mathrm{E}-05$ & 9.00 & -2.75 \\
\hline & se isomerase & & & & $1.23 \mathrm{E}-04$ & & 2.18 \\
\hline & Acy & 4.00 & 2.00 & $62 \mathrm{E}-05$ & $4.09 \mathrm{E}-05$ & -2.00 & -1.37 \\
\hline 157240 & nium transporter & 4.00 & 1.00 & $.62 \mathrm{E}-05$ & $4.09 \mathrm{E}-05$ & -4.00 & -1.37 \\
\hline 323454160 & Peptidase & 2.00 & 1.33 & $5.59 \mathrm{E}-03$ & $9.21 \mathrm{E}-03$ & -1.50 & 1.65 \\
\hline 323452383 & $\begin{array}{l}\text { Ribose-phosphate } \\
\text { pyrophosphokinase }\end{array}$ & 0.33 & 3.67 & $1.12 \mathrm{E}-04$ & $8.18 \mathrm{E}-05$ & 11.00 & -1.37 \\
\hline 23448438 & RNA binding protein & 3.00 & 1.33 & $8.71 \mathrm{E}-04$ & $3.27 \mathrm{E}-04$ & -2.25 & -2.66 \\
\hline & Proteasome & 3.00 & 2.67 & 7.59E-04 & $4.91 \mathrm{E}-04$ & -1.12 & -1.55 \\
\hline 323452898 & Glutamate dehydrogenase & 0.33 & 3.00 & 1.69E-04 & $4.09 \mathrm{E}-05$ & 9.00 & -4.12 \\
\hline 323451071 & Ribosomal protein & 3.33 & 0.33 & $2.81 \mathrm{E}-05$ & $8.18 \mathrm{E}-05$ & -10.00 & 2.91 \\
\hline & Ras small GTPase & 0.33 & 2.67 & 3.37E-04 & $2.45 \mathrm{E}-04$ & 8.00 & -1.37 \\
\hline 323449160 & Proteasome & 5.00 & 0.33 & 7.87E-04 & $8.59 \mathrm{E}-04$ & -15.00 & 1.09 \\
\hline
\end{tabular}




\begin{tabular}{|c|c|c|c|c|c|c|c|}
\hline 323454354 & Ormate nitrite transporter & 2.33 & 2.00 & 3.09E-04 & 4.91E-04 & $\mid-1.17$ & 1.59 \\
\hline 323450131 & $\begin{array}{l}\text { Xanthine/uracil/vitamin C } \\
\text { permease }\end{array}$ & 1.67 & 2.33 & $2.81 \mathrm{E}-05$ & $4.09 \mathrm{E}-05$ & 1.40 & 1.46 \\
\hline 323452963 & Light inducinble protein & 1.33 & 2.33 & $6.18 \mathrm{E}-04$ & $5.32 \mathrm{E}-04$ & 1.75 & -1.16 \\
\hline 323449422 & Luteovirus ORF6 protein & 3.33 & 1.33 & $5.62 \mathrm{E}-05$ & $1.23 \mathrm{E}-04$ & -2.50 & 2.18 \\
\hline 323455449 & Ribosomal protein & 2.67 & 1.00 & $2.53 \mathrm{E}-04$ & $2.86 \mathrm{E}-04$ & -2.67 & 1.13 \\
\hline 323451675 & Hypothetical protein & 1.67 & 2.00 & $8.43 \mathrm{E}-05$ & $4.09 \mathrm{E}-05$ & 1.20 & -2.06 \\
\hline 323452748 & $\begin{array}{l}\text { TB2/DP1/HVA22 related } \\
\text { protein }\end{array}$ & 1.00 & 3.00 & $7.03 \mathrm{E}-04$ & $3.27 \mathrm{E}-04$ & 3.00 & -2.15 \\
\hline 323453524 & Glutathion transferase & 0.33 & 2.33 & $1.41 \mathrm{E}-04$ & $1.23 \mathrm{E}-04$ & 7.00 & -1.14 \\
\hline 323454682 & GDP dissociation protein & 0.33 & 2.33 & $8.43 \mathrm{E}-05$ & $8.18 \mathrm{E}-05$ & 7.00 & -1.03 \\
\hline 323453963 & $\begin{array}{l}\text { Chloroplast light harvesting } \\
\text { protein }\end{array}$ & 1.67 & 2.00 & $2.81 \mathrm{E}-05$ & $4.09 \mathrm{E}-05$ & 1.20 & 1.46 \\
\hline 323452943 & Ribosomal protein & 2.67 & 0.67 & $2.08 \mathrm{E}-03$ & $1.02 \mathrm{E}-03$ & -4.00 & -2.03 \\
\hline 323455143 & Ribosomal protein & 3.00 & 0.67 & $5.62 \mathrm{E}-05$ & $4.09 \mathrm{E}-05$ & -4.50 & -1.37 \\
\hline 323452812 & $\begin{array}{l}\text { Dihydrolipoamide } \\
\text { dehydrogenase }\end{array}$ & 5.00 & 0.33 & $1.12 \mathrm{E}-04$ & $1.23 \mathrm{E}-04$ & -15.00 & 1.09 \\
\hline 323448587 & Adenylosuccinate synthetase & 2.67 & 1.00 & $1.69 \mathrm{E}-04$ & $2.45 \mathrm{E}-04$ & -2.67 & 1.46 \\
\hline 323456068 & Heat shock protein & 1.67 & 1.00 & $8.43 \mathrm{E}-05$ & $4.09 \mathrm{E}-05$ & -1.67 & -2.06 \\
\hline 323448447 & Endopeptidase Clp activity & 2.00 & 2.00 & $5.34 \mathrm{E}-04$ & $3.68 \mathrm{E}-04$ & 1.00 & -1.45 \\
\hline 323447335 & Formate/nitrite transporter & 0.33 & 2.00 & $4.78 \mathrm{E}-04$ & $6.55 \mathrm{E}-04$ & 6.00 & 1.37 \\
\hline 323450320 & Ribosomal protein & 3.00 & 0.33 & $8.43 \mathrm{E}-05$ & $1.64 \mathrm{E}-04$ & -9.00 & 1.94 \\
\hline 323453003 & Vesicle coat complex & 1.67 & 1.67 & $5.62 \mathrm{E}-04$ & $4.50 \mathrm{E}-04$ & 1.00 & -1.25 \\
\hline 323453823 & Brix domain & 1.00 & 2.33 & $2.81 \mathrm{E}-05$ & $4.09 \mathrm{E}-05$ & 2.33 & 1.46 \\
\hline 323453684 & $\begin{array}{l}\mathrm{H}+\text {-transporting two-sector } \\
\text { ATPase }\end{array}$ & 0.67 & 1.67 & 7.59E-04 & $4.50 \mathrm{E}-04$ & 2.50 & -1.69 \\
\hline 323448789 & GUN4 like domain & 0.33 & 2.33 & $2.25 \mathrm{E}-04$ & $8.18 \mathrm{E}-05$ & 7.00 & -2.75 \\
\hline 323453085 & Calcium-binding EF-hand & 1.00 & 1.00 & $2.81 \mathrm{E}-05$ & $4.09 \mathrm{E}-05$ & 1.00 & 1.46 \\
\hline 323455637 & $\begin{array}{l}\text { RAN function family member } \\
\text { - supported with BLASTp }\end{array}$ & 0.33 & 1.33 & $3.09 \mathrm{E}-04$ & $1.64 \mathrm{E}-04$ & 4.00 & -1.89 \\
\hline 323454406 & Armet super family domain & 2.67 & 0.33 & $3.94 \mathrm{E}-04$ & $3.27 \mathrm{E}-04$ & -8.00 & -1.20 \\
\hline 323454381 & Cystathione gamma lyase & 2.00 & 0.33 & $2.81 \mathrm{E}-05$ & $1.64 \mathrm{E}-04$ & -6.00 & 5.82 \\
\hline 323451378 & Sterol methyltransferase & 0.33 & 2.33 & $1.41 \mathrm{E}-04$ & $1.23 \mathrm{E}-04$ & 7.00 & -1.14 \\
\hline 323453289 & $\begin{array}{l}\text { BLASTp putative protein } \\
\text { with GPS domain }\end{array}$ & 1.33 & 0.67 & $2.81 \mathrm{E}-04$ & $4.91 \mathrm{E}-04$ & -2.00 & 1.75 \\
\hline 323450531 & Calcium ATPase & 1.33 & 1.33 & $2.81 \mathrm{E}-05$ & $4.09 \mathrm{E}-05$ & 1.00 & 1.46 \\
\hline 323449845 & Hypothetical protein & 0.67 & 1.67 & $1.41 \mathrm{E}-04$ & $1.64 \mathrm{E}-04$ & 2.50 & 1.16 \\
\hline 323450569 & Ribosomal protein & 3.00 & 0.33 & $2.53 \mathrm{E}-04$ & $3.68 \mathrm{E}-04$ & -9.00 & 1.46 \\
\hline 323452077 & Ribosomal protein & 2.33 & 0.33 & $5.90 \mathrm{E}-04$ & 4.09E-04 & -7.00 & -1.44 \\
\hline 323452089 & $\begin{array}{l}\text { IMP dehydrogenase/GMP } \\
\text { reductase }\end{array}$ & 3.00 & 0.33 & $2.81 \mathrm{E}-05$ & $4.09 \mathrm{E}-05$ & -9.00 & 1.46 \\
\hline 323452833 & CAP protein & 0.33 & 2.33 & $2.81 \mathrm{E}-04$ & $2.45 \mathrm{E}-04$ & 7.00 & -1.14 \\
\hline 323456017 & CTP synthase & 1.00 & 1.00 & $5.62 \mathrm{E}-05$ & 4.09E-05 & 1.00 & -1.37 \\
\hline 323452600 & $\begin{array}{l}\text { Inorganic phosphate } \\
\text { transporter }\end{array}$ & 0.33 & 1.33 & $2.81 \mathrm{E}-05$ & $4.09 E-05$ & 4.00 & 1.46 \\
\hline 323447291 & Phosphoglycerate mutase & 0.67 & 2.00 & $1.97 \mathrm{E}-04$ & 4.09E-05 & 3.00 & -4.81 \\
\hline 323447671 & Ribosomal protein & 2.33 & 0.67 & $3.09 \mathrm{E}-04$ & $2.05 \mathrm{E}-04$ & -3.50 & -1.51 \\
\hline
\end{tabular}




\begin{tabular}{|c|c|c|c|c|c|c|c|}
\hline 323449776 & Urease & 2.33 & 1.33 & $5.62 \mathrm{E}-05$ & $8.18 \mathrm{E}-05$ & -1.75 & 1.46 \\
\hline 323453239 & $\begin{array}{l}\text { Proliferating cell nuclear } \\
\text { antigen, PCNA }\end{array}$ & 2.33 & 0.33 & $1.97 \mathrm{E}-04$ & 4.09E-05 & -7.00 & -4.81 \\
\hline 323452338 & $\begin{array}{l}\text { Helicase and restriction } \\
\text { enzyme domain }\end{array}$ & 1.67 & 0.33 & $8.43 \mathrm{E}-05$ & 1.23E-04 & -5.00 & 1.46 \\
\hline 323455998 & Alkaline phosphatase & 0.33 & 4.33 & $3.37 \mathrm{E}-04$ & $9.82 \mathrm{E}-04$ & 13.00 & 2.91 \\
\hline 23455705 & $\begin{array}{l}\text { Serine } \\
\text { hydroxymethyltransferase }\end{array}$ & 0.67 & 1.00 & $2.81 \mathrm{E}-05$ & $1.23 \mathrm{E}-04$ & 1.50 & 4.37 \\
\hline 323456188 & Heat shock protein & 0.67 & 0.67 & $2.81 \mathrm{E}-05$ & $8.18 \mathrm{E}-05$ & 1.00 & 2.91 \\
\hline 323456208 & Synaptobrevin & 0.33 & 2.33 & $1.97 \mathrm{E}-04$ & $6.55 \mathrm{E}-04$ & 7.00 & 3.33 \\
\hline 23452846 & Argininosuccinate synthase & 0.67 & 1.33 & $1.12 \mathrm{E}-04$ & $4.09 \mathrm{E}-05$ & 2.00 & -2.75 \\
\hline 23449583 & Ribosomal protein & 3.33 & 0.33 & $1.97 \mathrm{E}-04$ & $8.18 \mathrm{E}-05$ & -10.00 & -2.40 \\
\hline 323456496 & $\begin{array}{l}\text { AICARFT/IMPCHase } \\
\text { bienzyme, Methylglyoxal } \\
\text { synthase-like }\end{array}$ & 0.67 & 1.00 & $1.97 \mathrm{E}-04$ & $8.18 \mathrm{E}-05$ & 1.50 & -2.40 \\
\hline 323454389 & Translation initiaion factor & 1.67 & 0.33 & $3.09 \mathrm{E}-04$ & $8.18 \mathrm{E}-05$ & -5.00 & -3.78 \\
\hline 323455110 & $\begin{array}{l}\text { Uroporphyrinogen } \\
\text { decarboxylase (URO-D) }\end{array}$ & 0.67 & 2.00 & 1.12E-04 & $1.23 \mathrm{E}-04$ & 3.00 & 1.09 \\
\hline 323456121 & Actin like protein & 0.33 & 1.33 & $2.81 \mathrm{E}-04$ & $2.05 \mathrm{E}-04$ & 4.00 & -1.37 \\
\hline 453700 & Elongation factor & 1.33 & 0.33 & 8.43E-05 & $4.09 \mathrm{E}-05$ & -4.00 & -2.06 \\
\hline 453278 & Oxoglutarate dehydrogenase & 0.33 & 1.67 & $8.43 \mathrm{E}-05$ & $1.64 \mathrm{E}-04$ & 5.00 & 1.94 \\
\hline 454199 & DnaJ homolog & 0.67 & 0.67 & $8.43 \mathrm{E}-05$ & $1.23 \mathrm{E}-04$ & 1.00 & 1.46 \\
\hline 450083 & al protein & 1.6 & 0.33 & $6.18 \mathrm{E}-04$ & $2.86 \mathrm{E}-04$ & -5.00 & -2.16 \\
\hline 323452263 & $\begin{array}{l}\text { Peptidase / Proteasome } \\
\text { Succinyl-CoA synthetase, } \\
\text { ATP-citrate lyase/succinyl- }\end{array}$ & 2.00 & 0.33 & $2.25 \mathrm{E}-04$ & $4.09 \mathrm{E}-04$ & -6.00 & 1.82 \\
\hline 323450948 & $\begin{array}{l}\text { CoA ligase, Succinyl-CoA } \\
\text { synthetase, ATP-citrate } \\
\text { lyase/succinyl-CoA ligase }\end{array}$ & 1.67 & 0.67 & $2.81 \mathrm{E}-05$ & $1.23 \mathrm{E}-04$ & -2.50 & 4.37 \\
\hline 323451260 & Cobalamin synthesis protein & 0.33 & 2.00 & $2.81 \mathrm{E}-05$ & $8.18 \mathrm{E}-05$ & 6.00 & 2.91 \\
\hline 323451909 & $\begin{array}{l}\text { ATP } \\
\text { phosphoribosyltransferase }\end{array}$ & 1.67 & 0.33 & $1.97 \mathrm{E}-04$ & $8.18 \mathrm{E}-05$ & -5.00 & -2.40 \\
\hline 323448914 & Malate dehydrogenase & 0.33 & 0.67 & $1.38 \mathrm{E}-03$ & $1.47 \mathrm{E}-03$ & 2.00 & 1.07 \\
\hline 323457289 & $\begin{array}{l}\text { Eukaryotic initiation factor } \\
5 \mathrm{~A} \text { hypusine }\end{array}$ & 0.67 & 1.00 & 7.03E-04 & $1.23 \mathrm{E}-04$ & 1.50 & -5.72 \\
\hline 323448128 & $\begin{array}{l}\text { Peptidyl-prolyl cis-trans } \\
\text { isomerase }\end{array}$ & 0.67 & 1.33 & 1.12E-04 & $4.09 \mathrm{E}-05$ & 2.00 & -2.75 \\
\hline 447945 & Phosphofructokinase & 0.67 & 0.67 & $1.04 \mathrm{E}-03$ & $9.00 \mathrm{E}-04$ & 1.00 & -1.16 \\
\hline 323449674 & Peptidase & 1.00 & 0.33 & $2.25 \mathrm{E}-04$ & $1.23 \mathrm{E}-04$ & -3.00 & \\
\hline 323454473 & $\begin{array}{l}\text { Iron-dependent fumarate } \\
\text { hydratase, Fe-S type hydro- } \\
\text { lyases tartrate/fumarate }\end{array}$ & 0.33 & 1.33 & $2.81 \mathrm{E}-05$ & $1.23 \mathrm{E}-04$ & 4.00 & 4.37 \\
\hline 323449899 & Ribosomal protein & 2.00 & 0.33 & $8.43 \mathrm{E}-05$ & $1.23 \mathrm{E}-04$ & -6.00 & 1.46 \\
\hline 456455 & Ribosomal protein & 2.33 & 0.33 & $1.97 \mathrm{E}-04$ & $1.23 \mathrm{E}-04$ & -7.00 & -1.60 \\
\hline 451287 & Argininosuccinate lyase & 0.33 & 1.00 & $5.62 \mathrm{E}-05$ & $4.09 \mathrm{E}-05$ & 3.00 & -1.37 \\
\hline 453705 & Ammonium transporter & 2.33 & 0.67 & $5.62 \mathrm{E}-05$ & $4.09 \mathrm{E}-05$ & -3.50 & -1.37 \\
\hline 446944 & Hypothetical protein & 1.33 & 0.67 & 5.62E-04 & $2.45 \mathrm{E}-04$ & -2.00 & -2.29 \\
\hline 323454055 & Ribosomal protein & 1.67 & 0.33 & 2.25E-04 & $4.09 \mathrm{E}-05$ & -5.00 & \\
\hline 323450361 & Triosephosphate isomerase & 1.33 & 0.33 & $8.43 \mathrm{E}-05$ & $4.09 \mathrm{E}-05$ & -4.00 & \\
\hline
\end{tabular}




\begin{tabular}{|c|c|c|c|c|c|c|c|}
\hline 323453878 & Aspartyl-tRNA synthetase & 1.33 & 0.33 & $5.62 \mathrm{E}-05$ & $8.18 \mathrm{E}-05$ & -4.00 & 1.46 \\
\hline 323454189 & Ribosomal protein & 1.67 & 0.33 & $5.06 \mathrm{E}-04$ & $4.91 \mathrm{E}-04$ & -5.00 & -1.03 \\
\hline 323453434 & Nitrite reductase & 1.00 & 0.33 & $3.94 \mathrm{E}-04$ & $4.09 \mathrm{E}-05$ & -3.00 & -9.62 \\
\hline 323455015 & $\begin{array}{l}\text { Cycloartenol-C24- } \\
\text { methyltransferase }\end{array}$ & 0.33 & 2.33 & $2.25 \mathrm{E}-04$ & $1.64 \mathrm{E}-04$ & 7.00 & -1.37 \\
\hline 323452327 & Zn-finger & 0.33 & 0.67 & $2.81 \mathrm{E}-05$ & $8.18 \mathrm{E}-05$ & 2.00 & 2.91 \\
\hline 323449390 & Exportin & 0.33 & 2.33 & $8.43 \mathrm{E}-05$ & $4.09 \mathrm{E}-05$ & 7.00 & -2.06 \\
\hline 323455383 & $\begin{array}{l}\text { Phenylalanyl-tRNA } \\
\text { synthetase }\end{array}$ & 0.33 & 1.67 & $5.62 \mathrm{E}-05$ & 4.09E-05 & 5.00 & -1.37 \\
\hline 323451434 & Hypothetical protein & 0.33 & 1.00 & $5.62 \mathrm{E}-05$ & $8.18 \mathrm{E}-05$ & 3.00 & 1.46 \\
\hline 323452805 & $\begin{array}{l}\text { NADPH protochlorophyllide } \\
\text { reductase }\end{array}$ & 0.67 & 1.33 & $2.81 \mathrm{E}-05$ & $8.18 \mathrm{E}-05$ & 2.00 & 2.91 \\
\hline 323448712 & Thiolase & 0.67 & 0.33 & $5.62 \mathrm{E}-05$ & $8.18 \mathrm{E}-05$ & -2.00 & 1.46 \\
\hline 323449561 & Ribosomal protein & 1.33 & 0.33 & $5.62 \mathrm{E}-05$ & $1.64 \mathrm{E}-04$ & -4.00 & 2.91 \\
\hline 323450277 & Ribosomal Protein & 1.33 & 0.33 & $1.41 \mathrm{E}-04$ & $8.18 \mathrm{E}-05$ & -4.00 & -1.72 \\
\hline 323447741 & Nonaspanin & 0.33 & 0.33 & $8.43 \mathrm{E}-05$ & $4.09 \mathrm{E}-05$ & 1.00 & -2.06 \\
\hline 323451431 & $\begin{array}{l}\text { Chloroplast light harvesting } \\
\text { protein }\end{array}$ & 6.00 & 0.33 & $8.43 \mathrm{E}-04$ & 4.05E-03 & -18.00 & 4.80 \\
\hline 323456793 & Nuclear transport factor 2 & 0.67 & 0.33 & 3.94E-04 & $8.18 \mathrm{E}-05$ & -2.00 & -4.81 \\
\hline 323451135 & Proteasome & 1.67 & 0.33 & $6.75 \mathrm{E}-04$ & $5.73 \mathrm{E}-04$ & -5.00 & -1.18 \\
\hline 323448268 & Aldo/keto reductase & 0.33 & 0.67 & $2.81 \mathrm{E}-05$ & $4.09 \mathrm{E}-05$ & 2.00 & 1.46 \\
\hline 323452169 & Hypothetical protein & 0.33 & 0.67 & $4.22 \mathrm{E}-04$ & $3.27 \mathrm{E}-04$ & 2.00 & -1.29 \\
\hline 323448884 & Proteasome & 1.67 & 0.33 & $8.43 \mathrm{E}-05$ & $4.09 \mathrm{E}-05$ & -5.00 & -2.06 \\
\hline 323454580 & Glutathione peroxidase & 0.33 & 1.33 & $2.81 \mathrm{E}-05$ & $4.09 \mathrm{E}-05$ & 4.00 & 1.46 \\
\hline 323448448 & Nonphototropic hypocotyl & 2.33 & 0.33 & $2.81 \mathrm{E}-05$ & 4.09E-05 & -7.00 & 1.46 \\
\hline 323454894 & $\begin{array}{l}\text { Formylglycineamide ribotide } \\
\text { amidotransferase }\end{array}$ & 0.33 & 0.33 & $2.81 \mathrm{E}-05$ & 4.09E-05 & 1.00 & 1.46 \\
\hline 323448821 & ATPase, proteasome & 0.33 & 1.00 & 3.37E-04 & $6.14 \mathrm{E}-04$ & 3.00 & 1.82 \\
\hline 323450953 & Epsilon 1-COP & 0.33 & 0.67 & $2.25 \mathrm{E}-04$ & $2.45 \mathrm{E}-04$ & 2.00 & 1.09 \\
\hline 323454888 & $\begin{array}{l}\text { S-adenosylmethionine- } \\
\text { dependent methyltransferase } \\
\text { activity }\end{array}$ & 0.33 & 0.33 & $5.62 \mathrm{E}-05$ & $4.09 \mathrm{E}-05$ & 1.00 & -1.37 \\
\hline 323449847 & Proteasome & 0.67 & 0.33 & $2.81 \mathrm{E}-04$ & $1.23 \mathrm{E}-04$ & -2.00 & -2.29 \\
\hline 323454603 & Prolyl 4-hydroxylase & 0.33 & 1.00 & $2.81 \mathrm{E}-05$ & $1.64 \mathrm{E}-04$ & 3.00 & 5.82 \\
\hline 323447558 & $\begin{array}{l}\text { Glutamine } \\
\text { amidotransferase/cyclase }\end{array}$ & 0.33 & 1.00 & $8.43 \mathrm{E}-05$ & 4.09E-05 & 3.00 & -2.06 \\
\hline 323453323 & Elongation factor & 0.33 & 0.67 & $8.43 \mathrm{E}-05$ & $4.09 \mathrm{E}-05$ & 2.00 & -2.06 \\
\hline 323448551 & Prolyl-tRNA synthetase & 0.33 & 0.67 & $2.81 \mathrm{E}-05$ & $4.09 \mathrm{E}-05$ & 2.00 & 1.46 \\
\hline 323449787 & Hedgehog protein & 0.33 & 1.33 & $8.43 \mathrm{E}-05$ & $2.05 \mathrm{E}-04$ & 4.00 & 2.43 \\
\hline 323447426 & Isoleucine trna synthetase & 0.33 & 0.67 & $4.78 \mathrm{E}-04$ & $3.27 \mathrm{E}-04$ & 2.00 & -1.46 \\
\hline 323449971 & Phypo stress protein & 0.33 & 0.67 & $1.12 \mathrm{E}-04$ & $2.05 \mathrm{E}-04$ & 2.00 & 1.82 \\
\hline 323455262 & tRNA synthetases & 1.00 & 0.33 & $5.62 \mathrm{E}-05$ & $4.09 \mathrm{E}-05$ & -3.00 & -1.37 \\
\hline 323455416 & $\begin{array}{l}\text { Geranylgeranyl diphosphate } \\
\text { synthase }\end{array}$ & 0.67 & 0.67 & $1.69 \mathrm{E}-04$ & $8.18 \mathrm{E}-05$ & 1.00 & -2.06 \\
\hline 323450170 & Hypothetical protein & 0.67 & 0.33 & $8.43 \mathrm{E}-05$ & 4.09E-05 & -2.00 & -2.06 \\
\hline 323449569 & $\begin{array}{l}\text { Coatomer WD associated } \\
\text { region }\end{array}$ & 0.33 & 1.00 & $8.71 \mathrm{E}-04$ & $2.45 \mathrm{E}-04$ & 3.00 & -3.55 \\
\hline 323451541 & Ras small GTPase & 0.33 & 0.33 & $2.25 \mathrm{E}-04$ & $1.23 \mathrm{E}-04$ & 1.00 & -1.83 \\
\hline
\end{tabular}




\begin{tabular}{|c|c|c|c|c|c|c|c|}
\hline 323448259 & Mitochondrial carrier protein & 0.33 & 1.33 & $1.41 \mathrm{E}-04$ & $1.64 \mathrm{E}-04$ & 4.00 & 1.16 \\
\hline 323457329 & $\begin{array}{l}\text { Proteasome non-ATPase } \\
\text { regulatory subunit }\end{array}$ & 0.33 & 0.33 & 1.12E-04 & $8.18 \mathrm{E}-05$ & 1.00 & -1.37 \\
\hline 323453797 & Chloroplast Chaperonin & 0.33 & 1.00 & $8.43 \mathrm{E}-05$ & $1.23 \mathrm{E}-04$ & 3.00 & 1.46 \\
\hline 323450033 & Acyl-CoA synthetase & 0.67 & 0.33 & 1.12E-04 & $1.23 \mathrm{E}-04$ & -2.00 & 1.09 \\
\hline 323451609 & Alanine transaminase & 0.33 & 0.67 & $2.81 \mathrm{E}-05$ & $4.09 \mathrm{E}-05$ & 2.00 & 1.46 \\
\hline 323454572 & $\begin{array}{l}\text { Acyltransferase region, } \\
\text { Thioestarase }\end{array}$ & 0.33 & 0.67 & $1.69 \mathrm{E}-04$ & $2.05 \mathrm{E}-04$ & 2.00 & 1.21 \\
\hline 323452117 & $\begin{array}{l}\text { Delta 1-pyrroline-5- } \\
\text { carboxylate reductase (P5CR) }\end{array}$ & 0.33 & 0.33 & $1.12 \mathrm{E}-04$ & 4.09E-05 & 1.00 & -2.75 \\
\hline 323446697 & $\begin{array}{l}\text { 3-hydroxyacyl-CoA } \\
\text { dehydrogenase }\end{array}$ & 0.33 & 0.33 & $5.62 \mathrm{E}-05$ & $1.23 \mathrm{E}-04$ & 1.00 & 2.18 \\
\hline 323449869 & $\begin{array}{l}\text { Tryptophanyl-tRNA } \\
\text { synthetase }\end{array}$ & 0.33 & 0.33 & $8.43 E-05$ & $2.45 \mathrm{E}-04$ & 1.00 & 2.91 \\
\hline 323447574 & $\begin{array}{l}\text { Dynein heavy chain, AAA } \\
\text { ATPase }\end{array}$ & 0.33 & 0.33 & $8.43 \mathrm{E}-05$ & $1.64 \mathrm{E}-04$ & 1.00 & 1.94 \\
\hline 323446558 & Ribosomal protein & 1.33 & 0.33 & $3.65 \mathrm{E}-03$ & $2.41 \mathrm{E}-03$ & -4.00 & -1.51 \\
\hline 323447748 & AAA ATPase & 0.33 & 0.33 & $4.22 \mathrm{E}-04$ & $1.23 \mathrm{E}-04$ & 1.00 & -3.43 \\
\hline 323451194 & $\mathrm{ABC}$ transporter & 0.33 & 0.33 & $5.62 \mathrm{E}-05$ & $4.09 \mathrm{E}-05$ & 1.00 & -1.37 \\
\hline 323452072 & $\begin{array}{l}\text { ATP-dependent RNA helicase } \\
\text { DBP3 }\end{array}$ & 0.33 & 0.33 & $2.81 \mathrm{E}-05$ & $8.18 \mathrm{E}-05$ & 1.00 & 2.91 \\
\hline 323455685 & $\begin{array}{l}\text { Pyridoxamine } 5 \text { '-phosphate } \\
\text { oxidase-related } \\
\text { Peptidase M, neutral zinc }\end{array}$ & 0.33 & 0.33 & $5.62 \mathrm{E}-05$ & $8.18 \mathrm{E}-05$ & 1.00 & 1.46 \\
\hline 323456269 & $\begin{array}{l}\text { metallopeptidases, zinc- } \\
\text { binding site }\end{array}$ & 0.67 & 0.33 & $1.69 \mathrm{E}-04$ & $2.86 \mathrm{E}-04$ & -2.00 & 1.70 \\
\hline 323450302 & Acyl-CoA dehydrogenase & 0.33 & 0.33 & $2.25 \mathrm{E}-04$ & $4.50 \mathrm{E}-04$ & 1.00 & 2.00 \\
\hline
\end{tabular}


CHAPTER FOUR

Targeted gene expression in cultures and field populations of Aureococcus anophagefferens: Patterns in nitrogen and phosphorus metabolism.

\author{
Louie L. Wurcha \\ Elyse A. Walker c \\ Christopher J. Gobler ${ }^{c}$ \\ Sonya T. Dyhrman b,d \\ aMIT-WHOI Joint Program in Oceanography/Applied Ocean Science and \\ Engineering, Cambridge, MA 02139 \\ bWoods Hole Oceanographic Institution Biology Department \\ Woods Hole, MA 02543
}

cStony Brook University, School of Marine and Atmospheric Sciences

Stony Brook, NY 11794

dCorresponding author: sdyhrman@whoi.eduFax: (508) 457-2134 


\section{Abstract:}

Aureococcus anophagefferens, the harmful alga responsible for brown tides, has adversely affected coastal ecosystems in the Eastern U.S. Past research efforts have focused on the factors leading to bloom initiation and decline such as nutrient preference and supply. However, these field studies have relied on community level approaches such as bulk uptake rates and elemental composition. Gene expression offers a promising metric for examining species-specific nutrition in natural populations of $A$. anophagefferens. In this study, quantitative gene expression assays were developed to examine nitrogen $(\mathrm{N})$ and phosphorus $(\mathrm{P})$ deficiency in axenic cultures of $A$. anophagefferens. Results demonstrate that a phosphate transporter (PTA3) is up-regulated over 500-fold in cells experiencing P-deficiency relative to a P-replete environment. This expression signal degrades upon P readdition in a matter of hours. Furthermore, PTA3 expression was not regulated by $\mathrm{N}$ deficiency, but was up-regulated about 40 -fold when cells were exponentially growing on ammonium. Four genes involved in $\mathrm{N}$ metabolism were examined as a potential marker of $\mathrm{N}$ deficiency including a xanthine/uracil/vitamin $\mathrm{C}$ transporter (XUV), a formate/nitrite transporter (NAR1.3), a urea transporter (DUR2), and a formamidase/acetamidase enzyme (FMD2). Expression patterns demonstrate all $\mathrm{N}$ metabolism genes tested show differential expression in response to $\mathrm{N}$ supply. The most promising candidate for assaying $\mathrm{N}$ deficiency was the XUV gene, which was up-regulated $\sim 50$-fold when nitrate grown cells experience $\mathrm{N}$ deficiency and $\sim 35$ fold when ammonium grown cells experience $\mathrm{N}$ deficiency. XUV expression rapidly 
declined after two hours. Further, XUV expression was not governed by $\mathrm{P}$ supply. The expression of XUV and PTA3 was analyzed in samples from a natural brown tide bloom. Results suggest that as the bloom is growing toward peak cell densities, $A$. anophagefferens is not experiencing $\mathrm{N}$ or $\mathrm{P}$ deficiency and may be growing on ammonium.

\section{Introduction:}

Brown tides caused by the pelagophyte Aureococcus anophagefferens have adverse effects on the coastal environment and caused substantial losses to commercially important shellfish where these events occur (see reviews by Gobler et. al. 2005, Sunda et al. 2006). As a result, A. anophagefferens blooms are classified as ecosystem destructive algal blooms, a term prescribed to harmful algal blooms (HABs) that can modify or degrade ecosystems (Sunda et al. 2006). The ability of $A$. anophagefferens to dominate its environment under certain conditions, and the severe consequences of its presence in coastal ecosystems, has led to $A$. anophagefferens becoming a widely studied HAB species.

Substantial effort has been invested into defining the environmental conditions that allow $A$. anophagefferens blooms to initiate, persist and eventually decline. Field studies have shown that nutrient supply and nutrient type may be important in this aspect (as reviewed Gobler et al. 2005). Natural assemblages of phytoplankton during brown tide events can assimilate reduced $\mathrm{N}$ (e.g. ammonia) and DON (e.g. urea and amino acids) and have a higher affinity for these compounds compared to nitrate (Lomas et al. 
1996, Berg et al. 1997; 2003, Mulholland et al. 2002; 2004). Low nitrate inputs have been positively correlated to brown tides around Long Island (LaRoche et al. 1997) while mesocosm experiments during a bloom pointed to an inverse correlation between DIN enrichment and A. anophagefferens cell densities (Keller and Rice, 1989). Experiments with DIN enrichment led to a decrease in the relative abundance of $A$. anophagefferens within the phytoplankton community (Gobler and Sañudo-Wilhelmy 2001, Gobler et al. 2002; 2004, Kana et al. 2004) signifying that $A$. anophagefferens is outcompeted when DIN is high. These results suggest that $A$. anophagefferens may not be experiencing $\mathrm{N}$ deficiency during peak bloom periods.

Although not as well studied, phosphorus (P) may be playing a significant role in controlling $A$. anophagefferens blooms. Culture work has demonstrated that $A$. anophagefferens can utilize some dissolved organic phosphorus (DOP) compounds such as glycerol-phosphate and adenosine monophosphate (Dzurica et al. 1989, Wurch et al. 2011). As with DIN, A. anophagefferens blooms tend to correlate with relatively low dissolved inorganic phosphorus (DIP) concentrations (Gobler et al. 2005). Further, during peak A. anophagefferens cell densities there is a significant reduction of DOP (Gobler et al. 2004). If $A$. anophagefferens is not experiencing $\mathrm{N}$ deficiency at peak cell densities, it is possible that $\mathrm{P}$ deficiency might be constraining these blooms.

Past studies of both $\mathrm{N}$ and $\mathrm{P}$ have provided valuable insight into how $\mathrm{N}$ and $\mathrm{P}$ availability may influence blooms. However, one of the fundamental challenges in definitively linking $\mathrm{N}$ and $\mathrm{P}$ supply to bloom dynamics is that there is a disconnect between single species responses and nutrient chemistry. Nutrient concentrations are not 
equal to nutrient fluxes, so it is difficult to correlate in situ nutrient measurements with $\mathrm{N}$ or $\mathrm{P}$ deficiency. Elemental ratios (e.g particulate $\mathrm{C}: \mathrm{N}: \mathrm{P})$ and nutrient uptake rates are community level approaches (Dyhrman 2008). In the case of brown tides, it is important to know the physiology of $A$. anophagefferens specifically. A potential way to bridge this gap is through the use of molecular techniques such as targeted gene expression. This approach offers a means in which the nutritional physiology of individual species living in complex mixed assemblages can be examined at the cellular level (Dyhrman 2008). However, this approach hinges on the ability to accurately comprehend both the organism's physiological potential encoded within its genome and how that genome is expressed under distinct environmental conditions.

Due to its importance, $A$. anophagefferens was the first HAB species to have its genome sequenced (Gobler et al. 2011). Insights gained from the genome sequence have provided a framework for understanding the potential niche of $A$. anophagefferens and how it responds to changes in its environment. For example, A. anophagefferens possesses genes for the uptake and/or metabolism of a variety of both inorganic and organic nitrogen $(\mathrm{N})$ compounds including nitrate, formate/nitrite, ammonia, nitriles, urea, amino acids and peptides, and others (Gobler et al. 2011). These data are supported by culture studies demonstrating the ability of $A$. anophagefferens to utilize these compounds as a sole N source (Berg et al. 2002, Mulholland et al. 2002, MacIntyre et al. 2004, Pustizzi et al. 2004, Berg et al. 2008). However, it is the ordered expression of the genome that determines an organism's ability to occupy a given environmental niche (as opposed to its potential niche). A global transcriptome profiling study revealed that $A$. 
anophagefferens up-regulates genes involved in reduced and organic $\mathrm{N}$ metabolism when nitrate is unavailable including a xanthine/uracil/vitamin $\mathrm{C}$ permease (XUV) and acetamidase/formamidase (FMD2) (Wurch et al. 2011). Another study identified that $A$. anophagefferens also up-regulates a urea transporter (DUR2) and nitrite transporter (NAR1.3) under N deficiency. A. anophagefferens also contains genes for the uptake and/or metabolism of inorganic and organic phosphorus $(\mathrm{P})$ compounds including esters, diesters and nucleotides (Gobler et al. 2011) and these genes are induced during P deficiency (Wurch et al. 2011). A phosphate transporter (PTA3) in A. anophagefferens was shown to be particularly responsive to P supply (Wurch et al. 2011, and Chapter 3). These results suggest that gene expression may be a good approach for assaying $\mathrm{N}$ and $\mathrm{P}$ deficiency in A. anophagefferens.

In this study, the expression patterns of the gene targets described above were examined through detailed time-course culture experiments as A. anophagefferens transitioned from a nutrient replete to N- or P-deficient environment. Expression patterns were also examined as $A$. anophagefferens transitioned back into a nutrient replete environment. Quantitative assays were developed for tracking the expression patterns of these gene targets in natural field populations. This work serves as a critical step in linking culture experiments with natural populations of $A$. anophagefferens and provides a platform for tracking $\mathrm{N}$ and $\mathrm{P}$ deficiency in $A$. anophagefferens populations over the course a brown tide bloom. 


\section{Materials and Methods:}

\section{Phosphorus experiment}

Axenic $A$. anophagefferens strain CCMP 1984 was obtained from the ProvasoliGuillard Center for the Culture of Marine Phytoplankton and used for all culture experiments. Control cultures were grown in triplicate, while low P cultures were grown in quadruplicate. Locally collected Vineyard Sound seawater was filtered $(0.2 \mu \mathrm{m})$ twice and used to make modified Ll media (see below) with no silica (Guillard and Hargraves 1993). Vitamins (thiamine, biotin, and $B_{12}$ were sterile filtered $(0.2 \mu \mathrm{m})$ and added to the media after autoclaving. For the $\mathrm{P}$ experiment, $\mathrm{P}$ concentrations in $\mathrm{L} 1$ media were modified as follows: $\mathrm{L} 1$ replete $\left(+\mathrm{P}\right.$ control; $\left.36 \mu \mathrm{M} \mathrm{PO}_{4}{ }^{3-}\right)$ and low phosphate (low $\mathrm{P} ; 2$ $\left.\mu \mathrm{M} \mathrm{PO}_{4}{ }^{3-}\right)$ (Table 1). Cells were grown at $18^{\circ} \mathrm{C}$ on a $14: 10$ hour light:dark cycle $(140$ umol quanta $\mathrm{m}^{-2} \mathrm{~s}^{-1}$ ) and growth was monitored daily by cell counting on a hemacytometer and tracking fluorescence on a Turner Designs fluorometer. Nutrient samples were collected by filtering out cells through acid washed $0.2 \mu \mathrm{m}$ polycarbonate filters and into acid washed tubes. Nutrient samples were sent to the Woods Hole Oceanographic Institution Nutrient Analytical Facility for analysis of ammonium, silicate, phosphate, nitrate + nitrite concentrations. Control cells were harvested on day 6 (Figure 1). Starting on day 4, cells were harvested daily for the low $\mathbf{P}$ treatment. On day 7 of the experiment, low $\mathrm{P}$ cells were pooled and redistributed into 4 flasks at equal volume. Two of the flasks were refed $36 \mu \mathrm{M}$ phosphate (low $\mathrm{P} /+\mathrm{P})$ while the other two flasks were not changed (low P/-P). In both cases, cells were harvested at T=2, 4, 6, 24 and 48 hours after redistribution (Table 1). Approximately 5 to $10 \times 10^{7}$ cells were 
harvested by filtration onto a $0.2 \mu \mathrm{m}$ polycarbonate filter and immediately placed in $1 \mathrm{~mL}$ CTAB extraction solution (Teknova, Hollister CA) amended with $1 \% \mathrm{~m} / \mathrm{v}$ polyvinylpyrrolidone, incubated at $50^{\circ} \mathrm{C}$ for 20 minutes, and snap frozen in liquid nitrogen. Samples were stored at $-80^{\circ} \mathrm{C}$ until further processing.

\section{Nitrogen experiment}

Strain and media preparation methods were identical to those described above except for the nutrient conditions. $\mathrm{N}$ concentrations in L1 media were modified as follows: $\mathrm{Ll}$ replete control $\left(+\mathrm{N}\right.$ control; $883 \mu \mathrm{M} \mathrm{NO}_{3}{ }^{-}$), nitrate grown (low $\mathrm{NO}_{3}{ }^{-} ; 50 \mu \mathrm{M}$ $\mathrm{NO}_{3}{ }^{-}$), ammonium grown (low $\mathrm{NH}_{4}{ }^{+} ; 50 \mu \mathrm{M} \mathrm{NH}{ }_{4}^{+}$) and a no $\mathrm{N}$ added negative control (no $\mathrm{N}$ added) (Table 1). Growth was monitored and nutrient samples were collected as described above. Photosynthetic efficiency of photosystem II was determined daily for the nitrogen experiment in all treatments by the $F_{v} / F_{m}$ method (Parkhill et al. 2001). In brief, $10 \mathrm{~mL}$ aliquots of cells were dark adapted for 30 minutes and initial fluorescence $\left(\mathrm{F}_{0}\right)$ was determined on a Turner Designs Fluorometer. Then, $50 \mu \mathrm{L}$ of $3 \mathrm{mM} 3^{\prime}-(3,4$ dichlorophenyl)-1', 1'-dimethyl urea (DCMU) in 100\% ethanol was added to each aliquot and maximal fluorescence $\left(F_{m}\right)$ was determined after 30 seconds. $F_{v} / F_{m}$ was calculated by: $F_{v} / F_{m}=\left(F_{m}-F_{0}\right) / F_{m}$. Between 5 and $10 \times 10^{7}$ cells were harvested daily starting on day 5 of the low $\mathrm{NO}_{3}{ }^{-}$condition. On day 7 , low $\mathrm{NO}_{3}{ }^{-}$cells were pooled and re-distributed into 4 flasks. Two of the flasks were not changed (low $\mathrm{NO}_{3}{ }^{-} /-\mathrm{NO}_{3}{ }^{-}$). In the other two flasks, nitrate was added to a concentration of $883 \mu \mathrm{M}$ (low $\mathrm{NO}_{3}{ }^{-} /+\mathrm{NO}_{3}{ }^{-}$). In both the low $\mathrm{NO}_{3}{ }^{-} /-\mathrm{NO}_{3}{ }^{-}$and low $\mathrm{NO}_{3}{ }^{-} /+\mathrm{NO}_{3}{ }^{-}$conditions, cells were harvested at $\mathrm{T}=2,4,6,24$, 
and 48 hours after redistribution ( 5 to $10 \times 10^{7}$ cells). On day 9 , low $\mathrm{NH}_{4}{ }^{+}$cells were pooled and re-distributed into 4 flasks. Two of the flasks were not changed (low $\mathrm{NH}_{4}^{+} /-$ $\mathrm{NH}_{4}^{+}$). In the other two flasks, ammonium was added to a concentration of only $50 \mu \mathrm{M}$ (low $\mathrm{NH}_{4}{ }^{+} /+\mathrm{NH}_{4}{ }^{+}$) due to toxicity of ammonium at high concentrations. In both the low $\mathrm{NH}_{4}{ }^{+} /-\mathrm{NH}_{4}{ }^{+}$and low $\mathrm{NH}_{4}{ }^{+} /+\mathrm{NH}_{4}{ }^{+}$conditions, cells were harvested at $\mathrm{T}=2,4,6,24$, and 48 hours after redistribution ( 5 to $10 \times 10^{7}$ ).

\section{Culture RNA isolation}

Approximately 1.0-4.0 $\mu \mathrm{g}$ of RNA was isolated from each sample using the UltraClean ${ }^{\circledR}$ Plant RNA Isolation Kit (MO BIO Laboratories, Inc., Carlsbad CA) with modified manufacturer's instructions. Samples were removed from $-80^{\circ} \mathrm{C}$ and incubated at $65^{\circ} \mathrm{C}$ for 10 minutes. Then, the samples were centrifuged at $10,000 \times g$ to separate cell lysate from the filter and $650 \mu \mathrm{L}$ of supernatant was transferred to a fresh $1.5 \mathrm{~mL}$ tube. Second, $300 \mu \mathrm{L}$ of PMR1 was added to each sample and vortexed, followed by the addition of $800 \mu \mathrm{L}$ of PMR4 to each sample and again vortexed. Last, samples were loaded onto the columns and RNA extraction continued according to manufacturer's instructions. Isolated RNA was then treated with TURBO ${ }^{\mathrm{TM}}$ DNase (Ambion, Austin TX) to remove potential genomic DNA contamination. The RNA was quantified spectrophotometrically for yield and purity. For each sample, 100 ng of RNA was primed with oligo dT primers and reverse transcribed into cDNA using the iScript Select cDNA Synthesis kit (Bio-Rad, Hercules CA). A second reaction containing no reverse transcriptase served as a control for genomic DNA contamination. Subsequent qRT-PCR 
analysis using reference and target genes showed no amplification $\left(C_{T}\right.$ values $\left.=N / A\right)$ in these controls suggesting all samples were free of genomic DNA contamination.

qRT-PCR assay

Species-specific primers were designed from genomic sequences for the following genes using MacVector (MacVector, Inc., Cary NC) or Primer3 (Rozen and Skaletsky 2000): Xanthine/Uracil/Vitamin C transporter (XUV; JGI protein ID: 52593), acetamidase/formamidase (FMD2; JGI protein ID: 37987), urea transporter (DUR2; JGI protein ID: 71789) and phosphate transporter (PTA3; JGI protein ID: 22152). Primers from a previous study (Berg et al. 2008) were also used for a formate/nitrite transporter (NAR1.3) and the constitutively expressed ubiquitin-conjugating enzyme (UbE2). UbE2 was demonstrated to be a good reference gene for $A$. anophagefferens because of its constitutive expression patterns over a range of physiological conditions (Berg et al. 2008). In this study, the $C_{T}$ values of UbE2 across treatments were fairly stable, with the majority of samples falling between 29-31. Amplicons for all primer sets were screened for secondary structure using Mfold software (Zuker 2003) to confirm the primers were qRT-PCR compatible. A qRT-PCR assay was designed to optimize primer efficiency between $90-110 \%$ and examine relative abundance of cDNA transcripts across treatments using the comparative $\mathrm{C}_{\mathrm{T}}\left(2^{-}{ }^{-\mathrm{Ct}}\right)$ method (Livak and Schmittgen 2001). The $\Delta \mathrm{C}_{\mathrm{T}}\left(\mathrm{C}_{\mathrm{T}}\right.$ target $-\mathrm{C}_{\mathrm{T}}$ reference) was examined over a range of cDNA concentrations (1 $0.001 \mathrm{ng})$ to determine which concentrations produced near equal amplification efficiencies between target and reference amplicons. A plot of the log cDNA dilution 
versus $\Delta \mathrm{C}_{\mathrm{T}}$ was constructed to ensure the absolute value of the slope did not differ significantly from zero. All qRT-PCR reactions were run in triplicate using Brilliant ${ }^{\circledR}$ II Fast SYBR ${ }^{(\mathbb{R})}$ Green qRT-PCR Master Mix (Agilent Technologies, Santa Clara CA) and analyzed on a Bio-Rad iCycleriQ ${ }^{(B)}$ qRT-PCR detection system (Bio-Rad. Hercules CA) with the following cycling parameters: $1 \times 95^{\circ} \mathrm{C} 5$ minutes, $45 \mathrm{x}$ : $95^{\circ} \mathrm{C}$ for 10 seconds, $62^{\circ} \mathrm{C}$ for 30 seconds. A dissociation curve was performed to check for non-specific amplification by holding $\mathrm{PCR}$ reactions at $95^{\circ} \mathrm{C}$ for 1 minute and lowering the temperature by $0.5^{\circ} \mathrm{C}$ every 10 seconds to $55^{\circ} \mathrm{C}$. A list of all primer sequences, concentration, and efficiencies can be found in Table 2 .

Fold-changes of target genes among conditions were determined using the Relative Expression Software Tool (REST) located at http://www.genequantification.de/download.html. REST accounts for differences in efficiency between primer sets. The $P$-values for each biological replicate were determined by a pair-wise fixed reallocation randomization analysis (Pfaffl et al. 2002). The fold-changes of the target genes were then averaged from two biological replicates for each condition. Differences between conditions were determined using a one-way analysis of variance (ANOVA) with a Tukey post test (significantly different if $P$-value $<0.05$ between conditions). Statistical $P$-values, average fold-changes, and standard deviations for each gene target on every biological sample are listed in Tables 4-9. 


\section{Expression of XUV and PTA3 from natural populations}

Natural samples during a brown tide bloom in Quantuck Bay (Suffolk County, Long Island, NY) were collected throughout the summer season in 2007. $A$. anophagefferens cell counts were determined according to the methods described in Stauffer et al. 2008. For RNA samples, approximately $25 \mathrm{~mL}$ of natural sea water was filtered onto $0.2 \mu \mathrm{m}$ polycarbonate filters and stored at $-80^{\circ} \mathrm{C}$. CTAB buffer (Teknova, Hollister CA) amended by the addition of $1 \%$ mass/volume polyvinylpyrrolidone was subsequently added for further processing. Samples were incubated at $65^{\circ} \mathrm{C}$ for 10 minutes, centrifuged for 2 minutes at $10,000 \times g$ and $750 \mu \mathrm{L}$ was transferred to a fresh tube. Then, $750 \mu \mathrm{L}$ of chloroform: isoamyl alcohol (24:1) was added and samples were vortexed for 5 minutes. Samples were then centrifuged for 15 minutes and the supernatant was transferred to a fresh tube. The addition of chloroform: isoamyl alcohol (24:1) was then repeated and samples were vortexed and centrifuged as described above. Again, supernatant was transferred to a fresh tube and $300 \mu \mathrm{L}$ of $5 \mathrm{M} \mathrm{NaCl}$ and $600100 \%$

$\mu \mathrm{L}$ Isopropyl alcohol was added to each sample and stored at $-20^{\circ} \mathrm{C}$ for at least 90 minutes. Samples were then centrifuged at $10,000 \times \mathrm{g}$ for 15 minutes and the supernatant was carefully removed from the RNA pellet. The RNA pelletes were washed by the addition of $100 \mu \mathrm{L}$ of $100 \%$ ethanol. Molecular grade water was then added to the RNA pellets. RNA was then treated with TURBO ${ }^{\mathrm{TM}}$ DNase (Ambion, Austin TX) to remove potential genomic DNA contamination. The RNA was quantified spectrophotometrically for yield and purity. For each sample, $100 \mathrm{ng}$ of RNA was primed with oligo dT primers and reverse transcribed into cDNA using the iScript Select 
cDNA Synthesis kit (Bio-Rad, Hercules CA). A second reaction containing no reverse transcriptase served as a control for genomic DNA contamination. Subsequent qRT-PCR analysis using reference and target genes showed no amplification $\left(C_{T}\right.$ values $\left.=N / A\right)$ in these controls suggesting all samples were free of genomic DNA contamination. A qRTPCR assay was designed for the XUV and PTA3 genes as described above. New efficiencies were calculated from dilutions of cDNA generated from two field samples tested: 6-25-07 and 7-2-07.

\section{Results:}

Phosphorus experiment:

To examine phosphate transporter (PTA3) expression as a function of phosphate availability, $A$. anophagefferens cells were grown in batch cultures under phosphate replete $(+\mathrm{P}$ control) and low $\mathrm{P}$ conditions (Figure 1). A comparison of $+\mathrm{P}$ control and low $\mathrm{P}$ growth data show that by day 6 , low $\mathrm{P}$ cell concentrations and fluorescence were slightly lower than in the $+\mathrm{P}$ control, suggesting that day 6 represents the onset of stationary phase of growth (Figure 1). By day 7, external phosphate concentrations were below detection limit $(50 \mathrm{nM})$ while nitrate concentrations remained high and $A$. anophagefferens cell densities had not increased from the previous day (Figure 1, Table 2).

Expression of PTA3 was examined in low P cells on days 4-7 and compared to expression in the $+\mathrm{P}$ control to calculate a fold change. On day 4 , low $\mathrm{P}$ cell growth resembled the $+\mathrm{P}$ control (Figure 1). Expression of PTA3 in low P cells on this day was 
not detected (Figure 2A, Table 3). On day 5, expression of PTA3 was roughly 500-fold higher in low $\mathrm{P}$ cells relative to the $+\mathrm{P}$ control (Figure 2A, Table 3 ) corresponding with low external phosphate concentrations (Figure 1, Table 2). On day 6, PTA3 expression peaked at approximately 2000-fold higher than the $+\mathrm{P}$ control (Figure 2A). This peak expression coincided with onset of stationary growth due to $\mathrm{P}$ deficiency and phosphate concentrations below the detection limit. Finally, on day 7, expression of PTA3 was still over 500-fold greater than the $+\mathrm{P}$ control (Figure 2A, Table 3).

To examine how quickly phosphate re-addition would repress PTA3 expression, a re-feed experiment was conducted on low P cells. As growth had become stationary on day 7 and external phosphate concentrations were below detection, this time was chosen to examine phosphate addition. Phosphate was spiked into two low P cultures (low $\mathrm{P} /+\mathrm{P}$ ), while two were left unchanged (low $\mathrm{P} /-\mathrm{P}$ ). After 24 hours, low $\mathrm{P} /+\mathrm{P}$ cells resumed growth while low $\mathrm{P} /$-P cells remained in stationary phase (Figure 1).

Expression of PTA3 was examined at 2, 4, 6, 24, and 48 hours after phosphate addition (low $\mathrm{P} /+\mathrm{P}$ ) or no phosphate addition (low $\mathrm{P} / \mathrm{-P}$ ) and compared to expression at $\mathrm{T}_{0}$, where PTA3 expression was over 500-fold higher than in the $+\mathrm{P}$ control. In the low $\mathrm{P} / \mathrm{P}$ cells, there was no significant difference in expression of PTA3 over the course of the 48 hours relative to $\mathrm{T}_{0}$ (Figure $2 \mathrm{~B}$, Table 4). After only 2 hours of phosphate addition, PTA3 was down-regulated almost 100 -fold in low $\mathrm{P} /+\mathrm{P}$ cells relative to $\mathrm{T}_{0}$ (Figure 2B, Table 4). By 4 hours, PTA3 was down-regulated approximately 600 -fold (Figure 2B, Table 4). After 6 hours, PTA3 was undetectable in one of the biological replicates. At 6 hours, the PTA3 transcript from one biological replicate was not detected, 
while the other replicate was down-regulated 200-fold. By 24 hours, the expression of PTA3 was undetectable in all biological replicates and remained undetectable after 48 hours (Figure 2B, Table 4).

\section{Nitrogen experiment}

A. anophagefferens cells were grown on $\mathrm{N}$ replete $(+\mathrm{N})$, low nitrate $\left(\right.$ low $\left.\mathrm{NO}_{3}{ }^{-}\right)$, and low ammonium (low $\mathrm{NH}_{4}{ }^{+}$) to examine how the expression patterns of the following four genes are influenced by both $\mathrm{N}$ source and $\mathrm{N}$ supply: xanthine/uracil/vitamin $\mathrm{C}$ transporter (XUV), formate/nitrite transporter (NAR1.3), urea transporter (DUR2), and acetamidase/formamidase (FMD2). A anophagefferens cells were also grown in a no N added control to ensure that growth in the other conditions was due to added $\mathrm{N}$ compounds and not residual $\mathrm{N}$ from the seawater base (Figure 3A-C). The fluorescence of cells in the low $\mathrm{NO}_{3}{ }^{-}$condition was identical to cells in the $+\mathrm{N}$ condition until day 6 , where the low $\mathrm{NO}_{3}{ }^{-}$cells reached a peak fluorescence of approximately 30 relative fluorescence units (Figure 3A). Continuing into day 7, cell concentrations continued to increase, but fluorescence remained steady in the low $\mathrm{NO}_{3}{ }^{-}$condition (Figure 3A,B). This transition between day 6 and day 7 coincided with a rapid drop in $F_{v} / F_{m}$ (Figure 3C).

A. anophagefferens cells in the low $\mathrm{NH}_{4}{ }^{+}$condition stayed in the lag phase of growth for a longer period of time, and did not reach onset of stationary phase growth until day 9 (Figure 4A-C). As with the low $\mathrm{NO}_{3}{ }^{-}$condition, the transition into stationary phase coincided with a rapid decline in $F_{v} / F_{m}$ (Figure 3C). There was no noticeable growth in the no $\mathrm{N}$ added control and $\mathrm{F}_{\mathrm{v}} / \mathrm{F}_{\mathrm{m}}$ steadily decreased throughout the experiment 
in this condition (Figure 3A-C). As such, cell counts and $F_{v} / F_{m}$ measurements were stopped after day 7 and fluorescence measurements were stopped after day 8 for this condition.

Exponentially growing A. anophagefferens cells from day 7 in the low $\mathrm{NH}_{4}^{+}$ condition were used as the reference condition for examining the expression of $\mathrm{N}$ metabolism genes as a function of $\mathrm{N}$ source and supply (Figure 4). The expression of XUV was roughly 3-fold higher on day 5, 24-fold higher on day 6, and 50-fold higher on day 7 of the low $\mathrm{NO}_{3}{ }^{-}$condition relative to the reference condition (Figure 5A, Table 5). In the $\mathrm{NH}_{4}^{+}$condition, expression of XUV was not significantly different from the control condition on day 8 , but was about 35 -fold higher on day 9 (Figure 5B). In both cases, expression of XUV increased as N supply decreased (Figures 3-5, Table 3). The NAR1.3 gene displayed a similar expression pattern as XUV. In the low $\mathrm{NO}_{3}{ }^{+}$condition, NAR 1.3 expression was approximately 4-fold higher on day 5, 46-fold higher on day 6, and 30-fold higher on day 7 (Figure 5B, Table 6). NAR1.3 expression was also over 8fold higher on day 8 and over 17-fold higher on day 9 in the $\mathrm{NH}_{4}{ }^{+}$condition (Figure 5B, Table 6). For DUR2, expression patterns were similar to XUV and NAR1.3, but the foldchanges were lower, reaching a maximum expression of about 10 -fold higher than the reference condition on day 7 of the low $\mathrm{NO}_{3}{ }^{-}$condition (Figure 5C, Table 6). The FMD2 gene was expressed almost 18-fold higher on day 5 of the low $\mathrm{NO}_{3}{ }^{-}$condition in one biological replicate, but was not detected in the other biological replicate (Figure 5D, Table 6). Expression of FMD2 appeared to steadily decrease as cells reached stationary phase in the low $\mathrm{NO}_{3}{ }^{-}$condition. The XUV, NAR1.3, and DUR2 gene expression 
patterns were similar in the low $\mathrm{NH}_{4}{ }^{+}$conditions, but the absolute fold-changes were lower (Figure 5A-C). The FMD2 gene was not differentially expressed in the low $\mathrm{NH}_{4}^{+}$ condition (Figure 5D).

A re-feed experiment was conducted to examine how quickly $\mathrm{N}$ re-addition would influence expression patterns of these $\mathrm{N}$ metabolism genes. Nitrate was spiked into two low $\mathrm{NO}_{3}{ }^{-}$cultures on day 7 (low $\mathrm{NO}_{3}{ }^{-} /+\mathrm{NO}_{3}{ }^{-}$), while two were left unchanged (low $\mathrm{NO}_{3}{ }^{-}$ / $-\mathrm{NO}_{3}{ }^{-}$). Similarly, ammonium was spiked into two low $\mathrm{NH}_{4}^{+}$cultures (low $\left.\mathrm{NH}_{4}{ }^{+} /+\mathrm{NH}_{4}{ }^{+}\right)$while two were left unchanged $\left(\mathrm{NH}_{4}^{+} /-\mathrm{NH}_{4}{ }^{+}\right)$. After 24 hours, fluorescence and cell concentrations increased in both the low $\mathrm{NO}_{3}{ }^{-} /+\mathrm{NO}_{3}{ }^{-}$and low $\mathrm{NH}_{4}{ }^{+} /+\mathrm{NH}_{4}{ }^{+}$conditions (Figure 3, 4). Further, $\mathrm{F}_{\mathrm{v}} / \mathrm{F}_{\mathrm{m}}$ recovered in the low $\mathrm{NO}_{3}{ }^{-} /+\mathrm{NO}_{3}{ }^{-}$ condition, but continued to decline low $\mathrm{NO}_{3}{ }^{-} /-\mathrm{NO}_{3}{ }^{-}$cells (Figure 3C). In the low $\mathrm{NH}_{4}{ }^{+}$ condition, cells were refed ammonium at the point where $F_{v} / F_{m}$ was beginning to decline (Figure 4). Therefore, the addition of $\mathrm{NH}_{4}^{+}$delayed the decline in $\mathrm{F}_{\mathrm{v}} / \mathrm{F}_{\mathrm{m}}$ by 24 hours rather than recovering it as seen in the case of the low $\mathrm{NO}_{3}{ }^{-} /+\mathrm{NO}_{3}{ }^{-}$condition (Figure 5).

Expression of XUV, NAR1.3, DUR2, and FMD2 was examined at T=2, 4, 6, 24, and 48 hours after $\mathrm{N}$ re-addition and compared to a $\mathrm{T}_{0}$ : low $\mathrm{NO}_{3}{ }^{-}$cells on day 7 for the low $\mathrm{NO}_{3}{ }^{-} /-\mathrm{NO}_{3}{ }^{-}$and low $\mathrm{NO}_{3}{ }^{-} /+\mathrm{NO}_{3}{ }^{-}$conditions low $\mathrm{NH}_{4}{ }^{+}$cells on day 9 for the low $\mathrm{NH}_{4}^{+} /-\mathrm{NH}_{4}^{+}$and low $\mathrm{NH}_{4}^{+} /-\mathrm{NH}_{4}^{+}$conditions (Figure 6, 7). In the low $\mathrm{NO}_{3}{ }^{-} /+\mathrm{NO}_{3}{ }^{-}$ condition, expression of XUV continued to increase for 4 hours where it reached maximum levels of about 4-fold higher than the reference condition (Figure 6A, Table 8). After only 2 hours of nitrate re-addition, expression of XUV decreased over 70 -fold compared to the reference condition (Figure 6A, Table 8). The expression of XUV 
remained down-regulated relative to the reference condition over the course of the re-feed until $\mathrm{T}=48$ hours where it was no longer detectable (Figure $6 \mathrm{~A}$, Table 8 ). The expression patterns of NAR1.3 and DUR2 were similar to that of XUV in both the low $\mathrm{NO}_{3}{ }^{-} /-\mathrm{NO}_{3}^{-}$ and low $\mathrm{NO}_{3}{ }^{-} /+\mathrm{NO}_{3}{ }^{-}$conditions, but the magnitudes of the fold-changes were less (Figure 6B, C, Table 8). The $\mathrm{C}_{\mathrm{T}}$ values for the FMD2 gene were outside the acceptable range for the low $\mathrm{NO}_{3}{ }^{-} /+\mathrm{NO}_{3}{ }^{-}$condition at $\mathrm{T}=2$ and 24 hours. However, at $\mathrm{T}=4,6$, and 48 hours, the expression of FMD2 was significantly less than the control condition (Figure 6D, Table 8).

In the ammonium re-addition experiment, XUV, NAR1.3, DUR2, and FMD2 were all significantly down-regulated at $\mathrm{T}=2$ hours in the low $\mathrm{NH}_{4}^{+} /+\mathrm{NH}_{4}^{+}$condition (Figure 7, Table 9). XUV was down-regulated over 120-fold in one biological replicate, and undetectable in the second biological replicate at $\mathrm{T}=2$ hours in the low $\mathrm{NH}_{4}{ }^{+} /+\mathrm{NH}_{4}{ }^{+}$ condition (Figure 7A, Table 9). After 4 hours, XUV expression was undetectable in both biological replicates. Continuing into $\mathrm{T}=6,24$, and 48 hours, XUV expression increased in the low $\mathrm{NH}_{4}^{+} /+\mathrm{NH}_{4}{ }^{+}$condition, but was still significantly less than the reference condition (Figure 7A, Table 9). In the low $\mathrm{NH}_{4}{ }^{+} /-\mathrm{NH}_{4}{ }^{+}$condition, expression of XUV showed little difference to the reference condition until $\mathrm{T}=48$ when expression was over 10-fold lower than the reference condition (Figure 7A, Table 9). Expression of NAR1.3 followed a similar pattern to XUV in the low $\mathrm{NH}_{4}{ }^{+} /+\mathrm{NH}_{4}{ }^{+}$condition (Figure $7 \mathrm{~B}$, Table 9). At T=2 hours, expression of NAR1.3 in the low $\mathrm{NH}_{4}{ }^{+} /+\mathrm{NH}_{4}{ }^{+}$condition was over 40 fold less than the reference condition in one biological replicate and not detected in the second biological replicate (Figure 7B, Table 9). At $\mathrm{T}=4$ and 6 hours, expression of 
NAR 1.3 in the low $\mathrm{NH}_{4}{ }^{+} /+\mathrm{NH}_{4}{ }^{+}$condition was still significantly less than the reference condition, but the fold-changes were less different (Figure 7B, Table 9). After 24 and 48 hours, expression of NAR1.3 in the low $\mathrm{NH}_{4}{ }^{+} /+\mathrm{NH}_{4}{ }^{+}$condition was not statistically different from the reference condition (Figure 7B, Table 9). No significant difference in expression of NAR1.3 was detected in the low $\mathrm{NH}_{4}{ }^{+} /-\mathrm{NH}_{4}{ }^{+}$condition at any time point (Figure 7B, Table 9). Expression of DUR2 was significantly less in the low $\mathrm{NH}_{4}{ }^{+} /+\mathrm{NH}_{4}{ }^{+}$ condition relative to the reference condition throughout the experiment, but again, the largest fold-changes were earlier in the experiment (Figure 7C, Table 9). Similar to XUV, in the low $\mathrm{NH}_{4}{ }^{+} /-\mathrm{NH}_{4}{ }^{+}$condition DUR2 expression was significantly less at $\mathrm{T}=24$ and 48 hours relative to the reference condition (Figure 7C, Table 9). Finally, expression of FMD2 in the low $\mathrm{NH}_{4}{ }^{+} /+\mathrm{NH}_{4}{ }^{+}$condition was about 35 -fold less than the reference condition in one biological replicate and undetectable in the second biological replicate (Figure 7D, Table 9). It remained undetectable in the low $\mathrm{NH}_{4}{ }^{+} /+\mathrm{NH}_{4}{ }^{+}$condition for the rest of the time course (Figure 7D, Table 9). Conversely, in the low $\mathrm{NH}_{4}^{+} /-\mathrm{NH}_{4}{ }^{+}$ condition, expression of FMD2 was not significantly different than the reference condition over the time course (Figure 7D, Table 9).

Expression of XUV was tested on low $\mathrm{P}$ conditions to ensure that expression patterns are indicative of $\mathrm{N}$ deficiency only. Expression was compared to exponentially growing $A$. anophagefferens cells from day 7 in the low $\mathrm{NH}_{4}{ }^{+}$condition. No significant differences in expression of XUV were observed on any low P sample tested relative to the reference condition. Expression of PTA3 was also tested on low $\mathrm{NO}_{3}{ }^{-}$and low $\mathrm{NH}_{4}^{+}$ conditions to ensure that expression patterns are indicative of $\mathrm{P}$ deficiency only. 
Exponentially growing $+\mathrm{P}$ control cells were used as the reference condition. Expression of PTA3 was undetectable in all low $\mathrm{NO}_{3}{ }^{-}$samples tested. However, expression of PTA3 was up-regulated about 40 -fold on low $\mathrm{NH}_{4}^{+}$day 7 (exponentially growing cells on ammonium). This expression decreased to only 4-fold higher than the reference condition as cells in the low $\mathrm{NH}_{4}{ }^{+}$condition entered stationary phase. Upon ammonium re-addition, PTA3 expression increased to a maximum of 60 -fold higher on low $\mathrm{NH}_{4}{ }^{+} /+\mathrm{NH}_{4}{ }^{+} \mathrm{T}=6$ hours.

Expression of XUV and PTA3 from natural populations

Two samples from different stages of a natural brown tide bloom in Quantuck Bay, (Suffolk County, Long Island, NY) were analyzed for XUV and PTA3 expression (Figure 8). Exponentially growing cells on ammonium ( $\mathrm{N}$ replete: low $\mathrm{NH}_{4}{ }^{+}$day 7 ) were used as the reference condition for XUV expression and exponentially growing $\mathrm{P}$ replete cells $(+\mathrm{P}$ control day 6$)$ were used as the reference condition for PTA3 expression. Expression of XUV was $\sim 2$-fold higher in both field samples tested relative to the reference condition (Figure 8). Expression of XUV during $\mathrm{N}$-deficient conditions (low $\mathrm{NO}_{3}$ day 7) is plotted for comparison. The expression of PTA3 was tested on only one field sample (6-25-07) due to problems with obtaining a near $100 \%$ amplification efficiency over a range of cDNA dilutions on the field sample from 7-2-07. Analysis of the sample from 6-25-07 demonstrated that PTA3 expression was approximately 80-fold higher than the reference condition. For comparison, expression of PTA3 from P replete 
exponentially growing cells on ammonium (low $\mathrm{NH}_{4}{ }^{+}$day 7) and stationary phase Pdeficient cells (low P day 7) is shown for comparison (Figure 8).

\section{Discussion:}

The aim of this research was to explore nutritional strategies of $A$. anophagefferens by analyzing the expression patterns of genes involved in $\mathrm{P}$ and $\mathrm{N}$ acquisition over time as $A$. anophagefferens transitioned into and out of a nutrientdeficient environment. Furthermore, these data were used to establish a species-specific indicator of $\mathrm{P}$ or $\mathrm{N}$ deficiency in natural populations of $A$. anophagefferens.

\section{Assaying P deficiency}

In a transcriptome profiling study, a phosphate transporter (PTA3) was shown to be up-regulated under P-deficient conditions (Wurch et al. 2011). Additionally, the protein for this gene also increases under P-deficiency (Chapter 3). Here, PTA3 expression was examined daily in batch cultures as A. anophagefferens approached $\mathrm{P}$ deficiency. PTA3 expression was first induced on day 5, before a noticeable effect was observed on cell growth (Figure 2A). In the first biological replicate, external phosphate concentrations were below the detection limit of the assay $(<50 \mathrm{nM})$ on day 5 and expression of the PTA3 was over 600 fold higher relative to the $+\mathrm{P}$ control. In the second biological replicate, phosphate concentrations were approximately $156 \mathrm{nM}$ and expression of PTA3 was about 360 -fold higher relative to the $+\mathrm{P}$ control. These results hint at a correlation between external phosphate concentrations and PTA3 expression. 
The highest expression levels of PTA3 correlated with the onset of stationary phase, when external phosphate concentrations were below the detection limit.

It is clear that PTA3 is induced under P deficiency, but in order to use it as a physiological marker it is important to determine how quickly the signal degrades upon alleviation of P deficiency. The re-feed experiment demonstrated that PTA3 expression is significantly down-regulated after 2 hours of $\mathrm{P}$ resupply (Figure 2B). This was the first time point examined, so it is difficult to determine exactly how quickly $A$. anophagefferens adjusts its expression of PTA3 when moving from a P-deficient to P replete environment. However, these results suggest that expression of PTA3 may be linked to $\mathrm{P}$ supply. If $\mathrm{P}$ is abundant, the PTA3 transcript is rapidly lost. If $\mathrm{P}$ becomes deficient, A. anophagefferens induces PTA3. A possible explanation for this induction is that $A$. anophagefferens is simply increasing the number of phosphate transporters, or switching to a more efficient one, when phosphate becomes low. This strategy has been seen in other eukaryotic phytoplankton (Chung et al. 2003, Dyhrman et al. 2006).

A recent proteomics study in Ostreococcus tauri revealed that proteins involved in phosphate transport were up-regulated under low nitrogen conditions (Le Bihan et al. 2011 ), therefore it was important to explore how PTA3 expression was influenced by $\mathrm{N}$ supply. In this study, the expression of PTA3 was not affected by $\mathrm{N}$ deficiency. When A. anophagefferens cells were growing on nitrate as their sole $\mathrm{N}$ source, and $\mathrm{P}$ was abundant, PTA3 expression was undetectable regardless of growth phase. This suggests that PTA3 expression is specific to $\mathrm{P}$ supply, an important consideration when interpreting expression patterns from field samples. However, PTA3 expression was 
about 40 -fold higher when cells were actively growing on ammonium as their sole $\mathrm{N}$ source. This result is consistent with a previous study in which this same gene (labeled PHO) was up-regulated $\sim 68$ times higher when cells were grown on ammonium relative to cells nitrate (Berg et al. 2008). The fact that PTA3 was not induced under $\mathrm{N}$ deficiency indicates that although PTA3 might be regulated by $\mathrm{N}$ source, it is not influenced by $\mathrm{N}$ deficiency. Given the magnitude of fold-changes of PTA3 under Pdeficient conditions, it should be possible to resolve whether or not the expression of PTA3 is being influenced by growth on ammonium or general P deficiency. However, more work needs to be done to examine is PTA3 expression is influenced by other $\mathrm{N}$ sources other than ammonium and nitrate.

\section{Assaying $N$ deficiency}

Four genes were considered for potential markers of $\mathrm{N}$ deficiency in $A$. anophagefferens. The xanthine/uracil/vitamin C permease is putatively involved with transport of nucleobases (purines and pyrimidines). It is unknown whether $A$. anophagefferens can utilize these compounds as a sole $\mathrm{N}$ source, however other algae, like the coccolithophore Emiliania huxleyi have been shown to utilize hypoxanthine, among other purine derivatives, as its sole $\mathrm{N}$ source (Palenik and Henson 1997). Furthermore, it was previously shown that $A$. anophagefferens induces this XUV during $\mathrm{N}$ deficiency, suggesting that purines/pyrimidines could be a potential $\mathrm{N}$ source (Wurch et al. 2011). In this study, as A. anophagefferens transitioned into an $\mathrm{N}$-deficient state, XUV expression increased. The highest XUV expression levels corresponded to a rapid 
decline in $F_{v} / F_{m}$. When ammonium or nitrate were re-supplied to the cells, the transcript signal was rapidly lost. The magnitude of the fold changes and the rapid loss of signal upon $\mathrm{N}$ re-addition suggests $\mathrm{XUV}$ is a good marker for assaying $\mathrm{N}$ deficiency in $A$. anophagefferens. This gene could potentially be used as a marker of $\mathrm{N}$ deficiency in other phytoplankton groups as well because it was demonstrated to be up-regulated under $\mathrm{N}$ deficiency in the diatom Thalassiosira pseudonana using a tiling array experiment (Mock et al. 2008).

The NAR1.3 and DUR2 genes also increased expression levels as cells approached $\mathrm{N}$ deficiency, however the fold changes were not nearly as high as seen in a previous study, which examined the expression of these genes under acute $\mathrm{N}$ deficiency (Berg et al. 2008). However, it is difficult to cross compare because of differences in seawater base (natural seawater versus artificial seawater) and reference conditions. In Berg et al. 2008, N replete cells grown on acetamide were used as the reference conditions. Nonetheless, the observation here that these genes are up-regulated under $\mathrm{N}$ deficiency is consistent with the overall patterns from the previous study. Little is known about whether $A$. anophagefferens can utilize nitrite as an $\mathrm{N}$ source. Furthermore, it is difficult to distinguish whether this transporter is transporting nitrite or formate. Formate is a compound that does not contain $\mathrm{N}$, and therefore would not be a potential $\mathrm{N}$ source. Urea, however, has been suggested to play an important role in $A$. anophagefferens growth (see review by Gobler et al. 2005). The expression of the urea transporter (DUR2) indicates that $A$. anophagefferens may be actively taking up urea. DUR2 was also induced as $A$. anophagefferens transitioned into $\mathrm{N}$ deficiency. This result 
supports the hypothesized importance of urea an $\mathrm{N}$ source when inorganic sources are unavailable.

Finally, expression of FMD2 was analyzed. FMD2 putatively hydrolyzes amides such as formamide or acetamide. In E. huxleyi, both formamide and acetamide were shown to be excellent $\mathrm{N}$ sources for growth (Palenik and Henson 1997). Acetamide has also been shown to support the growth of $A$. anophagefferens (Berg et al. 2008). Here, the expression of FMD2 was highest when cells were exponentially growing on nitrate. This is intriguing because the reference condition was exponentially growing cells on ammonium. As cells growing on nitrate transitioned into stationary phase, FMD2 expression started to decline. At first, these patterns suggest that FMD2 regulation is sensitive to the presence of nitrate and may be indicative of growth on nitrate. However, this result is confounded by the fact that when $\mathrm{N}$-deficient cells were re-supplied with nitrate, or re-supplied with ammonium, FMD2 expression declined.

In the ammonium re-addition experiment, all 4 genes tested were initially downregulated. However, after 48 hours the expression patterns trended toward $\mathrm{T}_{0}(\mathrm{~N}-$ deficient conditions). This is most likely due to the fact that only $50 \mu \mathrm{M}$ ammonium was re-supplied (compared to $883 \mu \mathrm{M}$ nitrate), which was not enough to keep the cultures from $\mathrm{N}$ deficiency over 48 hours. The $\mathrm{F}_{\mathrm{v}} / \mathrm{F}_{\mathrm{m}}$ rapidly declined between days 10 and 11 (corresponding to $\mathrm{T}=24$ and 48 hours after ammonium re-supply) suggesting that cells were actually experiencing $\mathrm{N}$ deficiency during that time. This would explain the expression patterns trending back toward $\mathrm{T}_{0}$ over the 48 hour period when ammonium was re-supplied, but not when the much more concentrated nitrate was re-supplied. 
Expression of XUV and PTA3 from natural populations

The expression patterns of XUV and PTA3 were examined in field populations on June 25, 2007 during brown tide bloom. This point marked the beginning of a rapid increase in growth as $A$. anophagefferens cell densities increased from $\sim 6.48 \times 10^{6}$ cells $/ \mathrm{mL}$ to $8.82 \times 10^{6}$ cells $/ \mathrm{mL}$ in a 24 hour period. Expression of XUV was about twofold higher than the reference condition (exponentially growing cells on ammonium). Given the magnitude of XUV up-regulation when cells are N-deficient, a 2-fold change would indicate that the cells were probably not experiencing $\mathrm{N}$ deficiency. The $\sim 60$-fold up-regulation of the PTA3 gene, however, is suggestive that these cells were growing on ammonium. A second sample was tested for XUV expression later in the bloom when cell concentrations were decreasing. Again, XUV was only up-regulated $\sim 2$-fold, suggesting that even when the bloom was declining, cells were not in a period of $\mathrm{N}$ deficiency.

One caveat to this interpretation is the fact that during acute $\mathrm{N}$ deficiency, when A.anophagefferens cells were initially grown on ammonium and in stationary phase for 48 hours, expression of XUV started to decline (Figure 7A). Therefore, it may be that the cells are so $\mathrm{N}$-deficient that they can no longer express XUV. Analysis of other ancillary data such as nutrient concentration or particulate $\mathrm{C}: \mathrm{N}: \mathrm{P}$ ratios may help discern which scenario is actually occurring. 
Summary

The results of this research provide a method for assaying $\mathrm{N}$ and $\mathrm{P}$ deficiency in natural populations of the harmful alga $A$. anophagefferens. As A. anophagefferens transitions from a nutrient replete to $\mathrm{N}$-deficient state, the XUV gene is induced. After only two hours of re-supplying N, the XUV signal rapidly degrades. Thus XUV is tightly linked with $\mathrm{N}$ supply. This is also the case for the PTA3 gene. As A. anophagefferens enters a P-deficient state, PTA3 is highly expressed, and the signal is rapidly degraded upon P re-supply. PTA3 is also induced, albeit at much lower levels, when cells are actively growing on ammonium. Therefore, PTA3 can potentially be used to assay both $\mathrm{P}$ deficiency as well as growth on ammonium. Application to natural bloom samples demonstrate that this method has strong potential for tracking the nutritional physiology of $A$. anophagefferens in its natural environment. More field samples need to be tested at different stages of the bloom and compared between years to distinguish the nutritional controls of $A$. anophagefferens blooms. 
Table 1) Culture conditions in this study.

\begin{tabular}{ll}
\hline Notation: & Description: \\
\hline$+\mathrm{P}$ & Cells grown in $\mathrm{L} 1$ replete media at $36 \mu \mathrm{M} \mathrm{PO}_{4}{ }^{3-}$ \\
low $\mathrm{P}$ & Cells grown in modified $\mathrm{L} 1$ media at $2 \mu \mathrm{M} \mathrm{PO}_{4}{ }^{3-}$ \\
$+\mathrm{N}$ & Cells grown in L1 replete media at $883 \mu \mathrm{M} \mathrm{NO}_{3}^{-}$ \\
low $\mathrm{NO}_{3}^{-}$ & Cells grown in modified L1 media at $50 \mu \mathrm{M} \mathrm{NO}_{3}^{-}$ \\
low $\mathrm{NO}_{3}^{-} /-\mathrm{NO}_{3}^{-}$ & Stationary phase, low $\mathrm{NO}_{3}^{-}$cells with no $\mathrm{NO}_{3}^{-}$addition \\
low $\mathrm{NO}_{3}^{-} /+\mathrm{NO}_{3}^{-}$ & Stationary phase, low $\mathrm{NO}_{3}^{-}$cells with $883 \mu \mathrm{M} \mathrm{NO}_{3}^{-}$addition \\
low $\mathrm{NH}_{4}^{+}$ & Cells grown in modified L1 media at $50 \mu \mathrm{M} \mathrm{NH}_{4}^{+}$ \\
low $\mathrm{NH}_{4}^{+} /-\mathrm{NH}_{4}^{+}$ & Stationary phase, low $\mathrm{NH}_{4}^{+}$cells with no $\mathrm{NH}_{4}^{+}$addition \\
low $\mathrm{NH}_{4}^{+} /+\mathrm{NH}_{4}^{+}$ & Stationary phase, low $\mathrm{NH}_{4}^{+}$cells with $50 \mu \mathrm{M} \mathrm{NH}_{4}^{+}$addition \\
no $\mathrm{Nadded}^{+}$ & Cells grown in L1 replete media with no nitrogen added \\
\hline
\end{tabular}


Table 2) List of primers used in this study.

\begin{tabular}{|c|c|c|c|c|c|c|c|}
\hline Gene target: & Gene symbol: & Accession: & Sequence: & Efficiency: & CT Range: & Concentration: & Amplicon size: \\
\hline Xanthine/Uracil/VitaminC permease & XUV & JGI: 52593 & $\begin{array}{l}\text { F: GTTCATGACGGCCATCTTCT } \\
\text { R: TCGTCGATCTTCGGGTAGAG }\end{array}$ & 105.0 & $25-33$ & $260 \mathrm{nM}$ & $245 \mathrm{nt}$ \\
\hline Formamidase & FMD2 & JGI: 37987 & $\begin{array}{l}\text { F: CCAGATCAAGAACGACGACA } \\
\text { R: GTAGTGGTCCGTGAGGAAGC }\end{array}$ & 111.4 & $27-34$ & $400 \mathrm{nM}$ & $208 \mathrm{nt}$ \\
\hline Formate/Nitrite transporter & NAR 1.3 & NCBI: EH058542 & $\begin{array}{l}\text { F: GAACTGGTTCGTCTGCTGG } \\
\text { R: CAGAAGTCGCCGTTGAAGTC }\end{array}$ & 99.6 & $28-34$ & $400 \mathrm{nM}$ & $201 \mathrm{nt}$ \\
\hline Urea transporter & DUR2 & JGI: 71789 & $\begin{array}{l}\text { F: CCACTACACCTTCCTCTTCTTCGG } \\
\text { R: CGTCTTCTTGAGCATCTCCCAG }\end{array}$ & 92.1 & $25-33$ & $400 \mathrm{nM}$ & $292 \mathrm{nt}$ \\
\hline Phosphate transporter & PTA3 & JGI: 22152 & $\begin{array}{l}\text { F: CATCCTCTACGGCATCACCAAG } \\
\text { R: ATCCAGAAGACGGAGTTGACGC }\end{array}$ & 104.9 & $22-36$ & $300 \mathrm{nM}$ & $141 \mathrm{nt}$ \\
\hline Ubiquitin-conjugating enzyme & $\mathrm{UbE} 2$ & NCBI: EH058515 & $\begin{array}{l}\text { F: GCGAGCTCCAGGACTTTATG } \\
\text { R: CGGGGTCGAGGAAGTAGAC } \\
\end{array}$ & 102.7 & $28-35$ & $400 \mathrm{nM}$ & $192 \mathrm{nt}$ \\
\hline
\end{tabular}


Table 3. Nutrient concentrations from the phosphorus and nitrogen experiments. Numbers are reported as the average \pm standard deviation of 2 or 3 measurements from a single biological sample.

\begin{tabular}{|c|c|c|c|c|c|c|c|c|c|}
\hline \multirow{2}{*}{$\begin{array}{l}\text { Sample } \\
\text { (biological replicate): } \\
\text { low P 4-27 (1) }\end{array}$} & \multirow{2}{*}{$\begin{array}{r}\text { Day(s) after } \\
\text { inocculation: }\end{array}$} & \multicolumn{2}{|c|}{$\mu \mathrm{M} \mathrm{NH}_{4}{ }^{+}:$} & \multicolumn{2}{|c|}{$\mu \mathrm{M}$ Silicate: } & \multicolumn{2}{|c|}{$\mu \mathrm{MPO}_{4}{ }^{3}$ : } & \multicolumn{2}{|c|}{$\mu \mathrm{M} \mathrm{NO}_{2}{ }^{-}+\mathrm{NO}_{3}=$} \\
\hline & & 0.931 & \pm 0.100 & 58.099 & \pm 0.578 & 1.382 & \pm 0.025 & 958.176 & \pm 17.598 \\
\hline low P 4-27(2) & 1 (Figure 1) & 0.583 & \pm 0.024 & 87.298 & \pm 2.666 & 1.408 & \pm 0.139 & 951.954 & \pm 0.000 \\
\hline low P 4-29(1) & 3 (Figure 1) & 0.691 & \pm 0.043 & 55.114 & \pm 0.178 & 1.310 & \pm 0.060 & 909.735 & \pm 6.912 \\
\hline low P 4-29 (2) & 3 (Figure 1) & 0.304 & \pm 0.024 & 84.614 & \pm 0.180 & 1.275 & \pm 0.026 & 1316.925 & \pm 8.447 \\
\hline low P 5-1 (1) & 5 (Figure 1 ) & 1.157 & \pm 0.010 & 56.559 & \pm 0.267 & $<0.050^{*}$ & & 899.180 & \pm 4.241 \\
\hline low P 5-1 (2) & 5 (Figure 1) & $<0.050^{*}$ & & 86.960 & \pm 0.886 & 0.156 & \pm 0.216 & 1328.579 & \pm 8.820 \\
\hline low P 5-2 (1) & 6 (Figure 1) & 2.248 & \pm 0.240 & 54.108 & \pm 2.577 & $<0.050^{*}$ & & 887.291 & \pm 3.456 \\
\hline low P 5-2 (2) & 6 (Figure 1) & 0.603 & \pm 0.052 & 84.470 & \pm 1.333 & $<0.050^{*}$ & & 927.066 & \pm 8.799 \\
\hline low P 5-3 (1) & 7 (Figure 1) & 1.719 & \pm 0.030 & 54.580 & \pm 0.755 & $<0.050^{*}$ & & 886.624 & \pm 4.400 \\
\hline low P 5-3 (2) & 7 (Figure 1) & $<0.050^{*}$ & & 87.095 & \pm 3.658 & $<0.050^{*}$ & & 1233.886 & \pm 7.899 \\
\hline low $\mathrm{NO}_{3}^{-} 5-7(1)$ & 2 (Figure 2) & 1.442 & \pm 0.212 & 58.162 & \pm 1.733 & 20.433 & \pm 1.785 & 52.637 & \pm 1.408 \\
\hline low $\mathrm{NO}_{3}^{-} 5-7(2)$ & 2 (Figure 2) & 1.161 & \pm 0.174 & 48.672 & \pm 2.444 & 21.740 & \pm 1.092 & 54.566 & \pm 0.616 \\
\hline low $\mathrm{NO}_{3}^{-} 5-9(1)$ & 4 (Figure 2) & $<0.050^{*}$ & & 80.642 & \pm 0.525 & 22.907 & \pm 1.184 & 32.198 & \pm 0.220 \\
\hline low $\mathrm{NO}_{3}-5-9(2)$ & 4 (Figure 2) & $<0.050^{*}$ & & 74.192 & \pm 1.362 & 21.912 & \pm 0.503 & 30.239 & \pm 3.784 \\
\hline low $\mathrm{NO}_{3} 5-10(1)$ & 5 (Figure 2) & $<0.050^{*}$ & & 77.298 & \pm 0.889 & 26.698 & \pm 0.334 & 18.417 & \pm 0.352 \\
\hline low $\mathrm{NO}_{3}^{-} 5-10(2)$ & 5 (Figure 2) & $<0.050^{*}$ & & 56.654 & \pm 1.200 & 22.855 & \pm 0.478 & 18.821 & \pm 0.044 \\
\hline low $\mathrm{NO}_{3}^{-} 5-11(1)$ & 6 (Figure 2) & $<0.050^{*}$ & & 72.584 & \pm 0.444 & 23.717 & \pm 0.045 & 0.063 & \\
\hline low $\mathrm{NO}_{3} \cdot 5-11(2)$ & 6 (Figure 2) & $<0.050^{*}$ & & 54.171 & \pm 0.622 & 24.631 & \pm 0.919 & 0.063 & \pm 0.002 \\
\hline low $\mathrm{NO}_{3} \cdot 5-12(1)$ & 7 (Figure 2) & 0.217 & \pm 0.010 & 71.642 & \pm 1.777 & 17.998 & \pm 0.417 & $<0.050^{*}$ & \\
\hline low $\mathrm{NO}_{3}-5-12(2)$ & 7 (Figure 2) & 0.662 & \pm 0.221 & 52.600 & \pm 1.333 & 20.833 & \pm 0.084 & $<0.050^{*}$ & \\
\hline low $\mathrm{NH}_{4}^{+} 5-7(1)$ & 2 (Figure 3 ) & 77.794 & \pm 0.566 & 81.383 & \pm 0.444 & 24.640 & \pm 1.575 & 2.878 & \pm 0.189 \\
\hline low $\mathrm{NH}_{4}^{+} 5-7(2)$ & 2 (Figure 3 ) & 68.485 & \pm 0.694 & 50.338 & \pm 0.355 & 15.004 & \pm 0.622 & 2.206 & \pm 0.761 \\
\hline low $\mathrm{NH}_{4}{ }^{+} 5-9(1)$ & 4 (Figure 3 ) & 63.894 & \pm 0.708 & 74.156 & \pm 1.777 & 22.897 & \pm 0.722 & 2.207 & \pm 0.003 \\
\hline low $\mathrm{NH}_{4}^{+} 5-9(2)$ & 4 (Figure 3) & 60.494 & \pm 0.424 & 73.103 & \pm 1.244 & 27.466 & \pm 0.251 & 2.455 & $\pm 0.25 \mathrm{l}$ \\
\hline low $\mathrm{NH}_{4}^{+} 5-11(1)$ & 6 (Figure 3 ) & 50.326 & \pm 0.495 & 79.812 & \pm 7.999 & 21.555 & \pm 1.413 & 1.969 & \pm 0.136 \\
\hline low $\mathrm{NH}_{4}{ }^{+} 5-11(2)$ & 6 (Figure 3 ) & 49.236 & \pm 0.226 & 52.066 & \pm 0.133 & 20.617 & \pm 0.505 & 2.845 & \pm 0.276 \\
\hline low $\mathrm{NH}_{4}{ }^{+} 5-13(1)$ & 8 (Figure 3 ) & 7.709 & \pm 0.976 & 76.669 & \pm 1.777 & 23.647 & \pm 0.723 & 2.728 & \pm 0.216 \\
\hline low $\mathrm{NH}_{4}^{+} 5-13(2)$ & 8 (Figure 3 ) & 6.638 & \pm 0.455 & 49.269 & \pm 1.066 & 32.250 & \pm 0.418 & 2.106 & \pm 0.216 \\
\hline low $\mathrm{NH}_{4}^{+} 5-14(1)$ & 9 (Figure 3) & 0.958 & \pm 0.150 & 79.497 & \pm 3.111 & 20.466 & \pm 0.352 & $<0.050^{*}$ & \\
\hline low $\mathrm{NH}_{4}^{+} 5-14(2)$ & 9 (Figure 3) & 0.158 & \pm 0.029 & 51.831 & \pm 1.116 & 24.633 & \pm 0.462 & $<0.050^{*}$ & \\
\hline
\end{tabular}

* Detection limit of the assay 
Table 4. Expression data for phosphate transporter (PTA3). A value under "Regulation" shows the fold change of that sample relative to the reference condition (+P control day 6: exponentially growing cells on replete phosphate; Figure 1). Bold indicates statistically signicant $(P$-value $<0.05)$ fold-changes using a pair-wise fixed reallocation randomization analysis based on triplicate wells. The high and low range represent the range of fold-changes calculated from the standard error of the mean (- and + error) for fold-changes.

\begin{tabular}{|l|l|l|ll|ll|l|l|}
\hline Gene: & $\begin{array}{l}\text { Sample } \\
\text { biological replicate): }\end{array}$ & Regulation: & Low range: & High range: & $(-)$ error: & $(+)$ error: & $P$-value: & Reference: \\
\hline PTA3 & low P day 4 (1) & ND & - & - & - & - & - & + +P control day 6 \\
PTA3 & low P day 4 (2) & ND & - & - & - & - & - & control day 6 \\
PTA3 & low P day 5 (1) & $\mathbf{6 3 6 . 3 2 6}$ & 446.596 & 1044.638 & 189.730 & 408.312 & 0.000 & + P control day 6 \\
PTA3 & low P day 5 (2) & $\mathbf{3 7 6 . 7 5 5}$ & 274.893 & 467.175 & 101.862 & 90.420 & 0.000 & + control day 6 \\
PTA3 & low P day 6 (1) & $\mathbf{2 1 4 8 . 1 1 1}$ & 1463.828 & 2966.989 & 684.283 & 818.878 & 0.000 & + +P control day 6 \\
PTA3 & low P day 6 (2) & $\mathbf{1 6 7 5 . 4 1 9}$ & 1201.020 & 2127.074 & 474.399 & 451.655 & 0.000 & + +P control day 6 \\
PTA3 & low P day 7 (1) & $\mathbf{5 4 8 . 2 1 9}$ & 378.044 & 843.319 & 170.175 & 295.100 & 0.000 & + P control day 6 \\
PTA3 & low P day 7 (2) & $\mathbf{5 9 7 . 9 4 7}$ & 456.954 & 776.513 & 140.993 & 178.566 & 0.021 & + control day 6 \\
\hline
\end{tabular}

${ }^{1} \mathrm{ND}$ : Not detected, meaning the $\mathrm{C}_{\mathrm{T}}$ values were higher than the effective efficiency range for the primers or no amplification occurred at all. 
Table 5. Expression data for phosphate transporter (PTA3). A value under "Regulation" shows the fold change of that sample relative to the reference condition (low $\mathrm{P}$ day 7 : stationary phase P-deficient cells; Figure 1). Bold indicates statistically signicant $(P$-value $<0.05)$ fold-changes using a pair-wise fixed reallocation randomization analysis based on triplicate wells. The high and low range represent the range of fold-changes calculated from the standard error of the mean (- and + error) for fold-changes.

\begin{tabular}{|c|c|c|c|c|c|c|c|c|}
\hline Gene: & $\begin{array}{l}\text { Sample } \\
\text { (biological replicate): }\end{array}$ & Regulation: & Low range: & High range: & (-) error: & $(+)$ error: & $P$-value: & Reference: \\
\hline PTA3 & low $\mathrm{P} / \mathrm{-P} \mathrm{T}=2 \mathrm{~h}(\mathrm{l})$ & -1.499 & 0.000 & -1.302 & $\mathrm{~N} / \mathrm{A}$ & 0.197 & 0.336 & low P day 7 (1) \\
\hline PTA3 & low $\mathrm{P} / \mathrm{-P} \mathrm{T}=2 \mathrm{~h}(2)$ & 2.257 & 1.305 & 4.240 & 0.952 & 2.935 & 0.170 & low P day 7 (2) \\
\hline PTA3 & low $\mathrm{P} /+\mathrm{P} \mathrm{T}=2 \mathrm{~h}(1)$ & -66.667 & -76.923 & -55.556 & 10.256 & 11.111 & 0.000 & low P day 7 (1) \\
\hline PTA3 & low $\mathrm{P} /+\mathrm{P} T=2 \mathrm{~h}(2)$ & -125.000 & -166.667 & -71.429 & 41.667 & 53.571 & 0.000 & low P day 7 (2) \\
\hline PTA3 & low $\mathrm{P} /-\mathrm{P} T=4 \mathrm{~h}(1)$ & 2.268 & 1.704 & 2.843 & 0.564 & 0.575 & 0.165 & low P day 7 (1) \\
\hline PTA3 & low $\mathrm{P} / \mathrm{-P} T=4 \mathrm{~h}(2)$ & 1.052 & 0.707 & 1.769 & 0.345 & 0.717 & 0.903 & low P day 7 (2) \\
\hline PTA3 & low $\mathrm{P} /+\mathrm{P} \mathrm{T}=4 \mathrm{~h}(1)$ & -1000.000 & -1000.000 & -500.000 & 0.000 & 500.000 & 0.000 & low P day 7 (1) \\
\hline PTA3 & low $\mathrm{P} /+\mathrm{P} \mathrm{T}=4 \mathrm{~h}(2)$ & -250.000 & -1000.000 & -66.667 & 750.000 & 183.333 & 0.000 & low P day 7 (2) \\
\hline PTA3 & low $\mathrm{P} / \mathrm{-P} \mathrm{T}=6 \mathrm{~h}(\mathrm{l})$ & 1.217 & 0.628 & 3.467 & 0.589 & 2.250 & 0.907 & low P day 7 (1) \\
\hline PTA3 & low $\mathrm{P} / \mathrm{-P} T=6 \mathrm{~h}(2)$ & 4.470 & 2.579 & 6.707 & 1.891 & 2.237 & 0.033 & low P day 7 (2) \\
\hline PTA3 & low $\mathrm{P} /+\mathrm{P} \mathrm{T}=6 \mathrm{~h}(1)$ & $\mathrm{ND}^{\prime}$ & - & - & - & - & - & low P day 7 (1) \\
\hline PTA3 & low $\mathrm{P} /+\mathrm{P} \mathrm{T}=6 \mathrm{~h}(2)$ & -200.000 & -333.333 & -111.111 & 133.333 & 88.889 & 0.000 & low P day 7 (2) \\
\hline PTA3 & low $\mathrm{P} / \mathrm{-P} \mathrm{T}=24 \mathrm{~h}(1)$ & -7.246 & -28.571 & -1.647 & 21.325 & 5.599 & 0.106 & low P day 7 (1) \\
\hline PTA3 & low $\mathrm{P} / \mathrm{-P} \mathrm{T}=24 \mathrm{~h}(2)$ & 2.372 & 1.337 & 3.379 & 1.035 & 1.007 & 0.000 & low P day 7 (2) \\
\hline PTA3 & low $\mathrm{P} /+\mathrm{P} T=24 \mathrm{~h}(1)$ & ND & - & - & - & - & - & low P day 7 (1) \\
\hline PTA3 & low $\mathrm{P} /+\mathrm{P} T=24 \mathrm{~h}(2)$ & ND & - & - & - & - & - & low P day 7 (2) \\
\hline PTA3 & low $\mathrm{P} /-\mathrm{P} T=48 \mathrm{~h}(1)$ & -1.143 & -1.276 & -1.019 & 0.133 & 0.123 & 0.490 & low P day 7 (1) \\
\hline PTA3 & low P/-P T=48h (2) & 1.073 & 0.634 & 2.094 & 0.439 & 1.021 & 0.830 & low P day 7 (2) \\
\hline PTA3 & low $\mathrm{P} / \mathrm{P} \mathrm{P}=48 \mathrm{~h}(\mathrm{l})$ & ND & - & - & - & - & - & low P day 7 (1) \\
\hline PTA3 & low $\mathrm{P} /+\mathrm{P} \mathrm{T}=48 \mathrm{~h}(2)$ & ND & - & - & - & - & - & low $P$ day 7 (2) \\
\hline
\end{tabular}

${ }^{1} \mathrm{ND}$ : Not detected, meaning the $\mathrm{C}_{\mathrm{T}}$ values were higher than the effective efficiency range for the primers or no amplification occurred at all. 
Table 6. Expression data for xanthine/uracil/vitamin $\mathrm{C}$ permease (XUV), acetamidase/formamidase (FMD2), urea transporter (DUR2), and formate/nitirte transporter (NAR1.3). A value under "Regulation" shows the fold change of that sample relative to the reference condition (low $\mathrm{NH}_{4}{ }^{+}$day 7 : exponentially growing cells on ammonium; Figure 4). Bold indicates statistically signicant $(\mathrm{P}$-value $<0.05$ ) fold-changes using a pair-wise fixed reallocation randomization analysis based on triplicate wells. The high and low range represent the range of fold-changes calculated from the standard error of the mean (- and + error) for fold-changes.

\begin{tabular}{|c|c|c|c|c|c|c|c|c|}
\hline Gene: & $\begin{array}{l}\text { Sample } \\
\text { (biological replicate): }\end{array}$ & Regulation: & Low range: & High range: & (-) error: & $(+)$ error: & $P$-value: & Reference: \\
\hline XUV & low $\mathrm{NO}_{3}$ day $5(1)$ & 2.237 & 1.059 & 5.769 & 1.178 & 3.532 & 0.202 & low $\mathrm{NH}_{4}^{+}$day 7 \\
\hline XUV & low $\mathrm{NO}_{3}$ day 5 (2) & 5.885 & 4.485 & 7.956 & 1.400 & 3.471 & 0.000 & low $\mathrm{NH}_{4}^{+}$day 7 \\
\hline XUV & low $\mathrm{NO}_{3}$ day $6(1)$ & 16.445 & 9.953 & 32.485 & 6.492 & 16.040 & 0.000 & low $\mathrm{NH}_{4}^{+}$day 7 \\
\hline XUV & low $\mathrm{NO}_{3}$ day $6(2)$ & 33.032 & 25.440 & 39.022 & 7.592 & 13.582 & 0.000 & low $\mathrm{NH}_{4}^{+}$day 7 \\
\hline XUV & low $\mathrm{NO}_{3}$ day 7 (1) & 54.988 & 26.762 & 94.600 & 28.226 & 39.612 & 0.000 & low $\mathrm{NH}_{4}{ }^{+}$day 7 \\
\hline XUV & low $\mathrm{NO}_{3}$ day 7 (2) & 44.185 & 36.290 & 54.694 & 7.895 & 18.404 & 0.036 & low $\mathrm{NH}_{4}{ }^{+}$day 7 \\
\hline NAR 1.3 & low $\mathrm{NO}_{3}$ day 5 (1) & 1.918 & 1.080 & 2.783 & 0.838 & 0.865 & 0.020 & low $\mathrm{NH}_{4}{ }^{+}$day 7 \\
\hline NAR 1.3 & low $\mathrm{NO}_{3}$ day $5(2)$ & 6.104 & 1.712 & 36.083 & 4.392 & 29.979 & 0.000 & low $\mathrm{NH}_{4}{ }^{+}$day 7 \\
\hline NAR 1.3 & low $\mathrm{NO}_{3}$ day $6(1)$ & 36.046 & 23.850 & 48.814 & 12.196 & 12.768 & 0.008 & low $\mathrm{NH}_{4}{ }^{+}$day 7 \\
\hline NAR 1.3 & low $\mathrm{NO}_{3}$ day $6(2)$ & 56.269 & 35.176 & 94.147 & 21.093 & 37.878 & 0.000 & low $\mathrm{NH}_{4}{ }^{+}$day 7 \\
\hline NAR 1.3 & low $\mathrm{NO}_{3}$ day 7 (1) & 47.553 & 34.430 & 61.293 & 13.123 & 13.740 & 0.010 & low $\mathrm{NH}_{4}{ }^{+}$day 7 \\
\hline NAR 1.3 & low $\mathrm{NO}_{3}$ day 7 (2) & 12.855 & 7.717 & 22.141 & 5.138 & 9.286 & 0.000 & low $\mathrm{NH}_{4}{ }^{+}$day 7 \\
\hline DUR2 & low $\mathrm{NO}_{3}$ day 5 (1) & -2.037 & -4.132 & -1.170 & 2.096 & 0.867 & 0.127 & low $\mathrm{NH}_{4}{ }^{+}$day 7 \\
\hline DUR2 & low $\mathrm{NO}_{3}$ day 5 (2) & 5.295 & 3.631 & 6.983 & 1.664 & 1.688 & 0.053 & low $\mathrm{NH}_{4}{ }^{+}$day 7 \\
\hline DUR2 & low $\mathrm{NO}_{3}$ day 6 (1) & 5.505 & 4.303 & 8.139 & 1.202 & 2.634 & 0.033 & low $\mathrm{NH}_{4}{ }^{+}$day 7 \\
\hline DUR2 & low $\mathrm{NO}_{3}$ day $6(2)$ & 10.653 & 9.064 & 13.572 & 1.589 & 2.919 & 0.000 & low $\mathrm{NH}_{4}{ }^{+}$day 7 \\
\hline DUR2 & low $\mathrm{NO}_{3}$ day 7 (1) & 12.628 & 10.008 & 19.039 & 2.620 & 6.411 & 0.000 & low $\mathrm{NH}_{4}{ }^{+}$day 7 \\
\hline DUR2 & low $\mathrm{NO}_{3}$, day 7 (2) & 9.848 & 8.756 & 11.840 & 1.092 & 1.992 & 0.000 & low $\mathrm{NH}_{4}{ }^{+}$day 7 \\
\hline FMD2 & low $\mathrm{NO}_{3}$ day $5(1)$ & $\mathrm{ND}^{!}$ & - & - & - & - & - & low $\mathrm{NH}_{4}{ }^{+}$day 7 \\
\hline FMD2 & low $\mathrm{NO}_{3}$ day $5(2)$ & 18.157 & 8.258 & 36.106 & 9.899 & 17.949 & 0.030 & low $\mathrm{NH}_{4}^{+}$day 7 \\
\hline FMD2 & low $\mathrm{NO}_{3}$ day $6(1)$ & 9.942 & 4.457 & 17.529 & 5.485 & 7.587 & 0.019 & low $\mathrm{NH}_{4}{ }^{+}$day 7 \\
\hline FMD2 & low $\mathrm{NO}_{3}$ day $6(2)$ & 12.484 & 6.089 & 26.068 & 6.395 & 13.584 & 0.000 & low $\mathrm{NH}_{4}{ }^{+}$day 7 \\
\hline FMD2 & low $\mathrm{NO}_{3}$ day 7 (1) & 8.536 & 4.249 & 16.339 & 4.287 & 7.803 & 0.000 & low $\mathrm{NH}_{4}{ }^{+}$day 7 \\
\hline FMD2 & low $\mathrm{NO}_{3}$ day 7 (2) & 3.558 & 1.76 & 7.204 & 1.798 & 3.646 & 0.141 & low $\mathrm{NH}_{4}{ }^{+}$day 7 \\
\hline
\end{tabular}

'ND: Not detected, meaning the $C_{T}$ values were higher than the effective efficiency range for the primers or no amplification occurred at all. 
Table 7. Expression data for xanthine/uracil/vitamin C permease (XUV), acetamidase/formamidase (FMD2), urea transporter (DUR2), and formate/nitirte transporter (NAR1.3). A value under "Regulation" shows the fold change of that sample relative to the reference condition (low $\mathrm{NH}_{4}{ }^{+}$day 7 : exponentially growing cells on ammonium; Figure 3). Bold indicates statistically signicant $(P$-value $<0.05)$ fold-changes using a pair-wise fixed reallocation randomization analysis based on triplicate wells. The high and low range represent the range of fold-changes calculated from the standard error of the mean (- and + error) for fold-changes.

\begin{tabular}{|c|c|c|c|c|c|c|c|c|}
\hline Gene: & $\begin{array}{l}\text { Sample } \\
\text { (biological replicate): }\end{array}$ & Regulation: & Low range: & High range: & (-) error: & $(+)$ error: & $P$-value: & Reference: \\
\hline XUV & $\mathrm{NH}_{4}^{+}$day $8(1)$ & 1.737 & 0.915 & 3.543 & 0.822 & 1.806 & 0.193 & low $\mathrm{NH}_{4}^{+}$day 7 \\
\hline XUV & $\mathrm{NH}_{4}{ }^{+}$day $8(2)$ & 1.015 & 0.797 & 1.267 & 0.218 & 0.252 & 0.868 & low $\mathrm{NH}_{4}{ }^{+}$day 7 \\
\hline XUV & $\mathrm{NH}_{4}{ }^{+}$day $9(1)$ & 21.247 & 9.948 & 44.746 & 11.299 & 23.499 & 0.008 & low $\mathrm{NH}_{4}{ }^{+}$day 7 \\
\hline XUV & $\mathrm{NH}_{4}{ }^{+}$day 9 (2) & 50.050 & 42.978 & 60.215 & 7.072 & 10.165 & 0.012 & low $\mathrm{NH}_{4}{ }^{+}$day 7 \\
\hline NAR 1.3 & $\mathrm{NH}_{4}{ }^{+}$day $8(1)$ & -1.037 & -2.525 & -0.467 & 1.488 & 0.571 & 0.894 & low $\mathrm{NH}_{4}{ }^{+}$day 7 \\
\hline NAR 1.3 & $\mathrm{NH}_{4}{ }^{+}$day $8(2)$ & 15.979 & 7.890 & 28.455 & 8.089 & 12.476 & 0.000 & low $\mathrm{NH}_{4}^{+}$day 7 \\
\hline NARI.3 & $\mathrm{NH}_{4}{ }^{+}$day $9(1)$ & 10.792 & 7.169 & 17.334 & 3.623 & 6.542 & 0.000 & low $\mathrm{NH}_{4}{ }^{+}$day 7 \\
\hline NAR 1.3 & $\mathrm{NH}_{4}{ }^{+}$day 9 (2) & 10.452 & 5.910 & 20.984 & 4.542 & 10.532 & 0.000 & low $\mathrm{NH}_{4}{ }^{+}$day 7 \\
\hline DUR2 & $\mathrm{NH}_{4}{ }^{+}$day $8(1)$ & 1.833 & 1.482 & 2.130 & 0.351 & 0.297 & 0.035 & low $\mathrm{NH}_{4}^{+}$day 7 \\
\hline DUR2 & $\mathrm{NH}_{4}{ }^{+}$day $8(2)$ & 2.908 & 1.723 & 4.628 & 1.185 & 1.720 & 0.000 & low $\mathrm{NH}_{4}^{+}$day 7 \\
\hline DUR2 & $\mathrm{NH}_{4}{ }^{+}$day 9 (1) & 7.160 & 6.294 & 9.045 & 0.866 & 1.885 & 0.036 & low $\mathrm{NH}_{4}{ }^{+}$day 7 \\
\hline DUR2 & $\mathrm{NH}_{4}{ }^{+}$day $9(2)$ & 4.738 & 2.906 & 7.360 & 1.832 & 2.622 & 0.000 & low $\mathrm{NH}_{4}{ }^{+}$day 7 \\
\hline FMD2 & $\mathrm{NH}_{4}{ }^{+}$day $8(1)$ & 1.399 & 0.603 & 3.309 & 0.796 & 1.910 & 0.593 & low $\mathrm{NH}_{4}{ }^{+}$day 7 \\
\hline FMD2 & $\mathrm{NH}_{4}{ }^{+}$day $8(2)$ & -1.018 & -2.632 & -0.406 & 1.613 & 0.612 & 0.900 & low $\mathrm{NH}_{4}{ }^{+}$day 7 \\
\hline FMD2 & $\mathrm{NH}_{4}{ }^{+}$day 9 (1) & 3.073 & 1.465 & 7.724 & 1.608 & 4.651 & 0.099 & low $\mathrm{NH}_{4}{ }^{+}$day 7 \\
\hline FMD2 & $\mathrm{NH}_{4}{ }^{+}$day $9(2)$ & 4.507 & 2.280 & 9.451 & 2.227 & 4.944 & 0.000 & low $\mathrm{NH}_{4}{ }^{+}$day 7 \\
\hline
\end{tabular}


Table 8. Expression data for xanthine/uracil/vitamin C permease (XUV), acetamidase/formamidase (FMD2), urea transporter (DUR2), and formate/nitirte transporter (NAR1.3). A value under "Regulation" shows the fold change of that sample relative to the reference condition (low $\mathrm{NO}_{3} \cdot$ day 7: stationary phase $\mathrm{N}$-deficient cells grown on nitrate; Figure 3). Bold indicates statistically signicant $(P$-value $<0.05)$ fold-changes using a pair-wise fixed reallocation randomization analysis based on triplicate wells. The high and low range represent the range of fold-changes calculated from the standard error of the mean ( and + error) for fold-changes.

\begin{tabular}{|c|c|c|c|c|c|c|c|c|}
\hline Gene: & $\begin{array}{l}\text { Sample } \\
\text { (biological replicate): }\end{array}$ & Regulation: & Low range & : High range: & $(-)$ error: & $(+)$ error: & $P$-value: & Reference: \\
\hline XUV & low $\mathrm{NO}_{3}-1-\mathrm{NO}_{3}^{-\mathrm{T}}=2 \mathrm{~h}(1)$ & 2.374 & 1.541 & 3.833 & 0.833 & 1.459 & 0.000 & low $\mathrm{NO}_{3}^{-}$day $7(2)$ \\
\hline XUV & low $\mathrm{NO}_{3} \%-\mathrm{NO}_{3}^{-} \mathrm{T}=2 \mathrm{~h}(2)$ & 2.700 & 1.460 & 4.264 & - & - & 0.094 & low $\mathrm{NO}_{3}$ - day 7 (2) \\
\hline XUV & low $\mathrm{NO}_{3}-1+\mathrm{NO}_{3}^{-} \mathrm{T}=2 \mathrm{~h}(1)$ & -100.000 & -125.000 & -55.556 & 25.000 & 44.444 & 0.037 & low $\mathrm{NO}_{3}$ day 7 (2) \\
\hline XUV & low $\mathrm{NO}_{3}^{-} /+\mathrm{NO}_{3}^{-} \mathrm{T}=2 \mathrm{~h}(2)$ & -47.619 & -62.500 & -34.483 & 14.881 & 13.136 & 0.034 & low $\mathrm{NO}_{3}$ day 7 (2) \\
\hline XUV & low $\mathrm{NO}_{3} \%-\mathrm{NO}_{3}^{-\mathrm{T}}=4 \mathrm{~h}(1)$ & 5.627 & 3.834 & 9.505 & 1.793 & 3.878 & 0.000 & low $\mathrm{NO}_{3}$ day 7 (2) \\
\hline XUV & low $\mathrm{NO}_{3}{ }^{-} /-\mathrm{NO}_{3}^{-} \mathrm{T}=4 \mathrm{~h}(2)$ & 2.290 & 1.809 & 2.804 & 0.481 & 0.514 & 0.000 & low $\mathrm{NO}_{3}$ day 7 (2) \\
\hline XUV & low $\mathrm{NO}_{3}-1+\mathrm{NO}_{3}^{-} \mathrm{T}=4 \mathrm{~h}$ (1) & -41.667 & -111.111 & -19.231 & 69.444 & 22.436 & 0.033 & low $\mathrm{NO}_{3}$ day 7 (2) \\
\hline XUV & low $\mathrm{NO}_{3}{ }^{-} /+\mathrm{NO}_{3}^{-} \mathrm{T}=4 h(2)$ & -18.519 & -22.727 & -14.706 & 4.209 & 3.813 & 0.000 & low $\mathrm{NO}_{3}$ day 7 (2) \\
\hline XUV & low $\mathrm{NO}_{3} \%-\mathrm{NO}_{3}^{-\mathrm{T}}=6 \mathrm{~h}(1)$ & -1.274 & -4.587 & -0.447 & 3.313 & 0.827 & 0.766 & low $\mathrm{NO}_{3}$ day 7 (2) \\
\hline XUV & low $\mathrm{NO}_{3} /-\mathrm{NO}_{3}^{-} \mathrm{T}=6 \mathrm{~h}(2)$ & 3.336 & 3.021 & 3.962 & 0.315 & 0.626 & 0.058 & low $\mathrm{NO}_{3}$ day \\
\hline XUV & low $\mathrm{NO}_{3}-1+\mathrm{NO}_{3}^{-\mathrm{T}}=6 \mathrm{~h}(1)$ & -90.909 & -333.333 & -21.277 & 242.424 & 69.632 & 0.010 & low $\mathrm{NO}_{3}$ day 7 (2) \\
\hline XUV & low $\mathrm{NO}_{3} /+\mathrm{NO}_{3}^{-} \mathrm{T}=6 \mathrm{~h}(2)$ & -50.000 & -62.500 & -35.714 & 12.500 & 14.286 & 0.000 & low $\mathrm{NO}_{3}$ day 7 (2) \\
\hline XUV & low $\mathrm{NO}_{3} /-\mathrm{NO}_{3}^{-} \mathrm{T}=24 \mathrm{~h}(1)$ & -3.311 & -6.711 & -1.493 & 3.400 & 1.819 & 0.000 & low $\mathrm{NO}_{3}$ day 7 (2) \\
\hline XUV & low $\mathrm{NO}_{3} /-\mathrm{NO}_{3}^{-} \mathrm{T}=24 \mathrm{~h}(2)$ & N/A & - & - & - & - & - & low $\mathrm{NO}_{3}$ day 7 (2) \\
\hline XUV & low $\mathrm{NO}_{3} \cdot 1+\mathrm{NO}_{3}^{-} \mathrm{T}=24 \mathrm{~h}(1)$ & $\mathrm{ND}^{\prime}$ & - & - & - & - & - & low $\mathrm{NO}_{3}$ day 7 (2) \\
\hline XUV & low $\mathrm{NO}_{3}^{-} /+\mathrm{NO}_{3}^{-} \mathrm{T}=24 \mathrm{~h}(2)$ & -52.632 & -90.909 & -23.810 & 38.278 & 28.822 & 0.030 & low $\mathrm{NO}_{3}$ \\
\hline XUV & low $\mathrm{NO}_{3}-1-\mathrm{NO}_{3}^{-\mathrm{T}}=48 \mathrm{~h}(1)$ & -1.570 & -5.650 & -0.389 & 4.080 & 1.181 & 0.648 & low $\mathrm{NO}_{3} \mathrm{c}$ \\
\hline XUV & low $\mathrm{NO}_{3} /-\mathrm{NO}_{3}^{-\mathrm{T}}=48 \mathrm{~h}(2)$ & -1.045 & -3.861 & -0.251 & 2.816 & 0.794 & 1.000 & low $\mathrm{NO}_{3}$ \\
\hline XUV & low $\mathrm{NO}_{3}{ }^{-} /+\mathrm{NO}_{3}^{-\mathrm{T}}=48 \mathrm{~h}$ (1) & ND & - & - & - & - & - & low $\mathrm{NO}_{3}$ day 7 (2) \\
\hline XUV & low $\mathrm{NO}_{3}-1+\mathrm{NO}_{3}^{-\mathrm{T}}=48 \mathrm{~h}(2)$ & ND & - & - & - & - & - & low $\mathrm{NO}_{3}$ day 7 (2) \\
\hline NAR 1.3 & low $\mathrm{NO}_{3} /-\mathrm{NO}_{3} \mathrm{~T}=2 \mathrm{~h}(1)$ & 1.885 & 0.948 & 3.024 & 0.937 & 1.139 & 0.290 & low $\mathrm{NO}_{3}^{-}$ \\
\hline NAR 1.3 & low $\mathrm{NO}_{3} \cdot-\mathrm{NO}_{3}^{-} \mathrm{T}=2 \mathrm{~h}(2)$ & 3.379 & 1.581 & 5.808 & 1.798 & 2.429 & 0.102 & low $\mathrm{NO}_{3}^{-}$ \\
\hline NAR 1.3 & low $\mathrm{NO}_{3}^{-} /+\mathrm{NO}_{3}^{-\mathrm{T}}=2 \mathrm{~h}(1)$ & -4.016 & -7.143 & -2.381 & 3.127 & & 00 & low $\mathrm{NO}_{3}$ \\
\hline NAR 1.3 & low $\mathrm{NO}_{3}^{-} /+\mathrm{NO}_{3}^{-\mathrm{T}}=2 \mathrm{~h}(2)$ & -1.131 & -1.212 & -1.029 & 0.081 & 0.102 & 0.018 & low $\mathrm{NO}_{3}$ \\
\hline NAR 1.3 & low $\mathrm{NO}_{3} /-\mathrm{NO}_{3}^{-} \mathrm{T}=4 \mathrm{~h}(1)$ & -1.883 & -2.899 & -1.152 & 1.015 & 0.731 & 0.023 & low $\mathrm{NO}_{3}$ \\
\hline NAR 1.3 & low $\mathrm{NO}_{3}-1-\mathrm{NO}_{3}^{-} \mathrm{T}=4 \mathrm{~h}(2)$ & -1.567 & -2.062 & -1.079 & 0.494 & 0.489 & & low $\mathrm{NO}_{3}$ \\
\hline NAR 1.3 & low $\mathrm{NO}_{3}{ }^{-} /+\mathrm{NO}_{3}^{-} \mathrm{T}=4 \mathrm{~h}(1)$ & -10.101 & -16.949 & -6.452 & 6.848 & 3.649 & 0.000 & low $\mathrm{NO}_{3}$ \\
\hline NAR 1.3 & low $\mathrm{NO}_{3}{ }^{-} /+\mathrm{NO}_{3}{ }^{-} \mathrm{T}=4 \mathrm{~h}(2)$ & -4.274 & -8.264 & -2.833 & 3.991 & 1.441 & 0.000 & low $\mathrm{NO}_{3}$ \\
\hline NAR 1.3 & low $\mathrm{NO}_{3} /-\mathrm{NO}_{3}^{-\mathrm{T}}=6 \mathrm{~h}(1)$ & 1.178 & 0.911 & 1.718 & 0.267 & 0.540 & & low $\mathrm{NO}_{3}$ \\
\hline NAR 1.3 & low $\mathrm{NO}_{3} /-\mathrm{NO}_{3}-\mathrm{T}=6 \mathrm{~h}(2)$ & 1.751 & 1.042 & 2.539 & 0.709 & 0.788 & 0.085 & low $\mathrm{NO}_{3} \mathrm{c}$ \\
\hline NAR 1.3 & low $\mathrm{NO}_{3}^{-} /+\mathrm{NO}_{3}^{-} \mathrm{T}=6 \mathrm{~h}$ (1) & -17.241 & -27.027 & -12.048 & 9.786 & 5.193 & 0.001 & low $\mathrm{NO}_{3}$ \\
\hline NAR 1.3 & low $\mathrm{NO}_{3}{ }^{-} /+\mathrm{NO}_{3}^{-} \mathrm{T}=6 \mathrm{~h}(2)$ & -7.813 & -16.949 & -4.673 & 9.137 & 3.140 & 000 & $y 7(2)$ \\
\hline NAR 1.3 & low $\mathrm{NO}_{3} /-\mathrm{NO}_{3}^{-\mathrm{T}}=24 \mathrm{~h}(1)$ & -1.088 & -1.661 & -0.623 & 0.573 & 0.465 & 0.681 & low $\mathrm{NO}_{3}$ day 7 (1) \\
\hline NAR 1.3 & low $\mathrm{NO}_{3}{ }^{-} /-\mathrm{NO}_{3}^{-} \mathrm{T}=24 \mathrm{~h}(2)$ & $\mathrm{N} / \mathrm{A}$ & - & - & - & - & - & low $\mathrm{NO}_{3}$ day 7 (2) \\
\hline NAR 1.3 & low $\mathrm{NO}_{3}-1+\mathrm{NO}_{3}^{-} \mathrm{T}=24 h(1)$ & $\mathrm{N} / \mathrm{A}$ & - & - & - & - & - & low $\mathrm{NO}_{3}$ day 7 (1) \\
\hline AR 1.3 & low $\mathrm{NO}_{3}{ }^{-} /+\mathrm{NO}_{3}{ }^{-\mathrm{T}}=24 \mathrm{~h}(2)$ & -5.348 & -7.937 & -4.115 & 2.589 & 1.232 & 0.000 & low $\mathrm{NO}_{3}$ day $7(2)$ \\
\hline NAR 1.3 & low $\mathrm{NO}_{3} /-\mathrm{NO}_{3} \cdot \mathrm{T}=48 \mathrm{~h}$ (1) & -1.689 & -2.375 & -1.163 & 0.686 & 0.526 & 0.039 & low $\mathrm{NO}_{3}$ \\
\hline NAR 1.3 & low $\mathrm{NO}_{3} /-\mathrm{NO}_{3} \cdot \mathrm{T}=48 \mathrm{~h}(2)$ & 1.401 & 0.687 & 3.567 & 0.714 & 2.1 & & low $\mathrm{NO}_{3} \mathrm{da}$ \\
\hline NAR 1.3 & low $\mathrm{NO}_{3}^{-} /+\mathrm{NO}_{3}^{-} \mathrm{T}=48 \mathrm{~h}(1)$ & -9.434 & -15.152 & -6.494 & 5.718 & 2.940 & 0.000 & low $\mathrm{NO}_{3}$ day 7 (1) \\
\hline AR 1.3 & low $\mathrm{NO}_{3}^{-} /+\mathrm{NO}_{3}^{-} \mathrm{T}=48 \mathrm{~h}(2)$ & -4.405 & -7.042 & -3.115 & 2.637 & 1.290 & 0.000 & low $\mathrm{NO}_{3}$ \\
\hline UR2 & low $\mathrm{NO}_{3} \%-\mathrm{NO}_{3} \mathrm{~T}=2 \mathrm{~h}(1)$ & -1.330 & -2.625 & -0.925 & 1.295 & 0.405 & 0.683 & low $\mathrm{NO}_{3} \mathrm{C}$ \\
\hline UR2 & low $\mathrm{NO}_{3} \%-\mathrm{NO}_{3}^{-} \mathrm{T}=2 \mathrm{~h}(2)$ & 3.023 & 1.232 & 7.108 & 1.791 & & & low $\mathrm{NO}_{3}$ day 7 (2) \\
\hline UR2 & low $\mathrm{NO}_{3}{ }^{-} /+\mathrm{NO}_{3}^{-} \mathrm{T}=2 \mathrm{~h}(1)$ & -10.309 & -11.905 & -9.174 & 1.595 & 1.135 & 0.040 & low $\mathrm{NO}_{3}$ day 7 (1) \\
\hline DUR2 & low $\mathrm{NO}_{3}{ }^{-} /+\mathrm{NO}_{3}^{-} \mathrm{T}=2 \mathrm{~h}(2)$ & -5.263 & -6.135 & -4.255 & 0.872 & 1.008 & 0.000 & low $\mathrm{NO}_{3}$ day $7(2)$ \\
\hline DUR2 & low $\mathrm{NO}_{3}^{-} /-\mathrm{NO}_{3}^{-} \mathrm{T}=4 \mathrm{~h}(1)$ & -1.992 & -3.067 & -0.924 & & & & low $\mathrm{NO}_{3}$ day 7 (1) \\
\hline DUR2 & low $\mathrm{NO}_{3} /-\mathrm{NO}_{3}^{-\mathrm{T}}=4 \mathrm{~h}(2)$ & 1.000 & 0.638 & 1.741 & 0.362 & 0.741 & 0.986 & low $\mathrm{NO}_{3}$ day 7 (2) \\
\hline
\end{tabular}




\begin{tabular}{|c|c|c|c|c|c|c|c|c|}
\hline DUR2 & low $\mathrm{NO}_{3}{ }^{-} /+\mathrm{NO}_{3}{ }^{-} \mathrm{T}=4 \mathrm{~h}(1)$ & -12.346 & -20.833 & -5.952 & 8.488 & 6.393 & 0.003 & low $\mathrm{NO}_{3}$ day 7 (1) \\
\hline DUR2 & low $\mathrm{NO}_{3}-1+\mathrm{NO}_{3}-\mathrm{T}=4 \mathrm{~h}(2)$ & -2.770 & -4.425 & -1.761 & 1.655 & 1.010 & 0.025 & low $\mathrm{NO}_{3}$ day 7 (2) \\
\hline DUR2 & low $\mathrm{NO}_{3} /-\mathrm{NO}_{3}^{-\mathrm{T}}=6 \mathrm{~h}(1)$ & 1.083 & 0.674 & 1.614 & 0.409 & 0.531 & 0.830 & low $\mathrm{NO}_{3}$ day 7 (1) \\
\hline DUR2 & low $\mathrm{NO}_{3}^{-} /-\mathrm{NO}_{3}^{-} \mathrm{T}=6 \mathrm{~h}(2)$ & 2.307 & 1.333 & 3.561 & 0.974 & 1.254 & 0.041 & low $\mathrm{NO}_{3}$ day 7 (2) \\
\hline DUR2 & low $\mathrm{NO}_{3}^{-} /+\mathrm{NO}_{3}^{-\mathrm{T}}=6 \mathrm{~h}(1)$ & -8.264 & -12.658 & -5.587 & 4.394 & 2.678 & 0.001 & low $\mathrm{NO}_{3}$ day 7 (1) \\
\hline DUR2 & low $\mathrm{NO}_{3}^{-} /+\mathrm{NO}_{3}^{-} \mathrm{T}=6 \mathrm{~h}(2)$ & -2.924 & -4.587 & -1.821 & 1.663 & 1.102 & 0.036 & low $\mathrm{NO}_{3}$ day 7 (2) \\
\hline DUR2 & low $\mathrm{NO}_{3}^{-} /-\mathrm{NO}_{3}^{-} \mathrm{T}=24 \mathrm{~h}(1)$ & -3.175 & -4.950 & -1.757 & 1.776 & 1.417 & 0.000 & low $\mathrm{NO}_{3}$ day 7 (1) \\
\hline DUR2 & low $\mathrm{NO}_{3}-/-\mathrm{NO}_{3}^{-} \mathrm{T}=24 \mathrm{~h}(2)$ & N/A & - & - & - & - & - & low $\mathrm{NO}_{3}$ day 7 (2) \\
\hline DUR2 & low $\mathrm{NO}_{3}^{-} /+\mathrm{NO}_{3}^{-\mathrm{T}}=24 \mathrm{~h}(1)$ & N/A & - & - & - & - & - & low $\mathrm{NO}_{3}$ day 7 (1) \\
\hline DUR2 & low $\mathrm{NO}_{3}^{-} /+\mathrm{NO}_{3}^{-} \mathrm{T}=24 \mathrm{~h}(2)$ & -6.849 & -7.576 & -5.714 & 0.726 & 1.135 & 0.000 & low $\mathrm{NO}_{3}$ day 7 (2) \\
\hline DUR2 & low $\mathrm{NO}_{3} /-\mathrm{NO}_{3}^{-} \mathrm{T}=48 \mathrm{~h}(1)$ & -2.538 & -3.802 & -1.859 & 1.264 & 0.679 & 0.000 & low $\mathrm{NO}_{3}$ day 7 (1) \\
\hline DUR2 & low $\mathrm{NO}_{3} /-\mathrm{NO}_{3}^{-} \mathrm{T}=48 \mathrm{~h}(2)$ & 1.154 & 0.555 & 2.093 & 0.599 & 0.939 & 0.760 & low $\mathrm{NO}_{3}$ day $7(2)$ \\
\hline DUR2 & low $\mathrm{NO}_{3}^{-} /+\mathrm{NO}_{3}^{-\mathrm{T}}=48 \mathrm{~h}(1)$ & -50.000 & -71.429 & -34.483 & 21.429 & 15.517 & 0.001 & low $\mathrm{NO}_{3}$ day 7 (1) \\
\hline DUR2 & low $\mathrm{NO}_{3}^{-} /+\mathrm{NO}_{3}^{-\mathrm{T}}=48 \mathrm{~h}(2)$ & -10.989 & -18.182 & -6.211 & 7.193 & 4.778 & 0.000 & low $\mathrm{NO}_{3}$ day 7 (2) \\
\hline FMD2 & low $\mathrm{NO}_{3}^{-} /-\mathrm{NO}_{3}-\mathrm{T}=2 \mathrm{~h}(1)$ & -1.429 & -2.618 & -0.739 & 1.189 & 0.689 & 0.473 & low $\mathrm{NO}_{3}$ day 7 (1) \\
\hline FMD2 & low $\mathrm{NO}_{3}-/-\mathrm{NO}_{3} \mathrm{~T}=2 \mathrm{~h}(2)$ & ND & - & - & - & - & - & low $\mathrm{NO}_{3}$ day 7 (2) \\
\hline FMD2 & low $\mathrm{NO}_{3}^{-} /+\mathrm{NO}_{3}^{-\mathrm{T}}=2 \mathrm{~h}(1)$ & ND & - & - & - & - & - & low $\mathrm{NO}_{3}$ day 7 (1) \\
\hline FMD2 & low $\mathrm{NO}_{3}-1+\mathrm{NO}_{3}^{-} \mathrm{T}=2 \mathrm{~h}(2)$ & ND & - & - & - & - & - & low $\mathrm{NO}_{3}$ day 7 (2) \\
\hline FMD2 & low $\mathrm{NO}_{3} /-\mathrm{NO}_{3}^{-} \mathrm{T}=4 \mathrm{~h}(\mathrm{l})$ & -2.740 & -4.444 & -1.656 & 1.705 & 1.084 & 0.019 & low $\mathrm{NO}_{3}$ day 7 (1) \\
\hline FMD2 & low $\mathrm{NO}_{3} /-\mathrm{NO}_{3}-\mathrm{T}=4 \mathrm{~h}(2)$ & 1.322 & 0.930 & 2.077 & 0.392 & 0.755 & 0.342 & low $\mathrm{NO}_{3}$ day 7 (2) \\
\hline FMD2 & low $\mathrm{NO}_{3}^{-} /+\mathrm{NO}_{3}^{-} \mathrm{T}=4 \mathrm{~h}(1)$ & ND & - & & - & - & - & low $\mathrm{NO}_{3}$ day 7 (1) \\
\hline FMD2 & low $\mathrm{NO}_{3} /+\mathrm{NO}_{3}^{-} \mathrm{T}=4 \mathrm{~h}(2)$ & -3.906 & -7.407 & -2.119 & 3.501 & 1.788 & 0.018 & low $\mathrm{NO}_{3}$ day 7 (2) \\
\hline FMD2 & low $\mathrm{NO}_{3}-/-\mathrm{NO}_{3}^{-\mathrm{T}}=6 \mathrm{~h}(1)$ & 1.072 & 0.548 & 2.028 & 0.524 & 0.956 & 0.907 & low $\mathrm{NO}_{3}$ day 7 (1) \\
\hline FMD2 & low $\mathrm{NO}_{3} /-\mathrm{NO}_{3}^{-} \mathrm{T}=6 \mathrm{~h}(2)$ & 3.806 & 1.953 & 9.010 & 1.853 & 5.204 & 0.002 & low $\mathrm{NO}_{3}$ day $7(2)$ \\
\hline FMD2 & low $\mathrm{NO}_{3}^{-} /+\mathrm{NO}_{3}^{-} \mathrm{T}=6 \mathrm{~h}(1)$ & -21.277 & -34.483 & -11.628 & 13.206 & 9.649 & 0.002 & low $\mathrm{NO}_{3}$ day 7 (1) \\
\hline FMD2 & low $\mathrm{NO}_{3}^{-} /+\mathrm{NO}_{3}^{-} \mathrm{T}=6 \mathrm{~h}(2)$ & -3.534 & -6.494 & -1.866 & 2.960 & 1.668 & 0.061 & low $\mathrm{NO}_{3}$ day 7 (2) \\
\hline FMD2 & low $\mathrm{NO}_{3} /-\mathrm{NO}_{3} \mathrm{~T}=24 \mathrm{~h}(1)$ & -2.358 & -11.765 & -0.689 & 9.406 & 1.669 & 0.496 & low $\mathrm{NO}_{3}$ day 7 (1) \\
\hline FMD2 & low $\mathrm{NO}_{3}^{-} /-\mathrm{NO}_{3}^{-} \mathrm{T}=24 \mathrm{~h}(2)$ & N/A & - & - & - & - & - & low $\mathrm{NO}_{3}$ day 7 (2) \\
\hline FMD2 & low $\mathrm{NO}_{3}^{-} /+\mathrm{NO}_{3}^{-} \mathrm{T}=24 \mathrm{~h}(1)$ & $\mathrm{N} / \mathrm{A}$ & - & - & - & - & - & low $\mathrm{NO}_{3}$ day 7 (1) \\
\hline FMD2 & low $\mathrm{NO}_{3} /+\mathrm{NO}_{3}^{-} \mathrm{T}=24 \mathrm{~h}(2)$ & ND & - & - & - & - & - & low $\mathrm{NO}_{3}$ day 7 (2) \\
\hline FMD2 & low $\mathrm{NO}_{3} /-\mathrm{NO}_{3}^{-} \mathrm{T}=48 \mathrm{~h}(1)$ & -1.669 & -3.731 & -0.723 & 2.062 & 0.947 & 0.375 & low $\mathrm{NO}_{3}$ day 7 (1) \\
\hline FMD2 & low $\mathrm{NO}_{3}^{-} /-\mathrm{NO}_{3} \mathrm{~T}=48 \mathrm{~h}(2)$ & 7.696 & 4.412 & 15.657 & 3.284 & 7.961 & 0.002 & low $\mathrm{NO}_{3}$ day $7(2)$ \\
\hline FMD2 & low $\mathrm{NO}_{3}^{-} /+\mathrm{NO}_{3}^{-\mathrm{T}}=48 \mathrm{~h}(1)$ & -21.277 & -37.037 & -10.101 & 15.760 & 11.176 & 0.003 & low $\mathrm{NO}_{3}$ day 7 (1) \\
\hline FMD2 & low $\mathrm{NO}_{3} /+\mathrm{NO}_{3}^{-} \mathrm{T}=48 \mathrm{~h}(2)$ & -2.262 & -5.587 & -0.976 & 3.324 & 1.287 & 0.236 & low $\mathrm{NO}_{3}$ day 7 (2) \\
\hline
\end{tabular}

${ }^{1} N D$ : Not detected, meaning the $C_{T}$ values were higher than the effective efficiency range for the primers or no amplification occurred at all. 
Table 9. Expression data for xanthine/uracil/vitamin C Permease (XUV), acetamidase/formamidase (FMD2), urea transporter (DUR2), and formate/nitirte transporter (NAR1.3). A value under "Regulation" shows the fold change of that sample relative to the reference condition (low $\mathrm{NH}_{4}{ }^{\prime}$ day 9: stationary phase $\mathrm{N}$-deficient cells grown on ammonium; Figure 4). Bold indicates statistically signicant $(P$-value $<0.05)$ fold-changes using a pair-wise fixed reallocation randomization analysis based on triplicate wells. The high and low range represent the range of fold-changes calculated from the standard error of the mean ( - and + error) for fold-changes.

\begin{tabular}{|c|c|c|c|c|c|c|c|c|}
\hline Gene: & $\begin{array}{l}\text { Sample } \\
\text { (biological replicate): }\end{array}$ & Regulation: & Low Range: & High Range: & (-) error: & $(+)$ error: & $P$-value: & Reference: \\
\hline $\mathrm{XUV}$ & low $\mathrm{NH}_{4}{ }^{+} /-\mathrm{NH}_{4}{ }^{+} \mathrm{T}=2 \mathrm{~h}(1)$ & 1.222 & 0.713 & 1.779 & 0.509 & 0.557 & 0.323 & low $\mathrm{NH}_{4}{ }^{1}$ day $9(1)$ \\
\hline XUV & low $\mathrm{NH}_{4}{ }^{+} /-\mathrm{NH}_{4}{ }^{\prime} \mathrm{T}=2 \mathrm{~h}(2)$ & -1.410 & -3.115 & -0.548 & 1.705 & 0.862 & 0.581 & low $\mathrm{NH}_{4}{ }^{4}$ day 9 (2) \\
\hline XUV & low $\mathrm{NH}_{4}{ }^{1} /+\mathrm{NH}_{4}{ }^{+} \mathrm{T}=2 \mathrm{~h}(1)$ & $\mathrm{ND}^{\prime}$ & - & - & - & - & - & low $\mathrm{NH}_{4}{ }^{\prime}$ day $9(1)$ \\
\hline XUV & low $\mathrm{NH}_{4}{ }^{+} /+\mathrm{NH}_{4}{ }^{+} \mathrm{T}=2 \mathrm{~h} \mathrm{(2)}$ & -125.000 & -142.857 & -111.111 & 17.857 & 13.889 & 0.000 & low $\mathrm{NH}_{4}{ }^{+}$day 9 (2) \\
\hline XUV & low $\mathrm{NH}_{4}{ }^{1} /-\mathrm{NH}_{4} \mathrm{~T}=4 \mathrm{~h}(1)$ & 1.210 & 0.717 & 2.031 & 0.493 & 0.821 & 0.561 & low $\mathrm{NH}_{4}{ }^{1}$ day 9 (1) \\
\hline XUV & low $\mathrm{NH}_{4}{ }^{+} /-\mathrm{NH}_{4}{ }^{+} \mathrm{T}=4 \mathrm{~h}(2)$ & -4.348 & -8.850 & -2.688 & 4.502 & 1.660 & 0.000 & low $\mathrm{NH}_{4}{ }^{+}$day $9(2)$ \\
\hline XUV & low $\mathrm{NH}_{4}{ }^{+} /+\mathrm{NH}_{4}{ }^{+} \mathrm{T}=4 \mathrm{~h}(1)$ & ND & - & - & - & - & - & low $\mathrm{NH}_{4}{ }^{+}$day $9(1)$ \\
\hline XUV & low $\mathrm{NH}_{4}{ }^{+} /+\mathrm{NH}_{4}{ }^{+} \mathrm{T}=4 \mathrm{~h}(2)$ & ND & - & - & - & - & - & low $\mathrm{NH}_{4}{ }^{+}$day $9(2)$ \\
\hline XUV & low $\mathrm{NH}_{4}{ }^{+} /-\mathrm{NH}_{4} \mathrm{~T}=6 \mathrm{~h}(1)$ & 1.593 & 1.115 & 2.960 & 0.478 & 1.367 & 0.088 & low $\mathrm{NH}_{4}$ day $9(1)$ \\
\hline XUV & low $\mathrm{NH}_{4}{ }^{+} /-\mathrm{NH}_{4}{ }^{+} \mathrm{T}=6 \mathrm{~h}(2)$ & -1.439 & -3.289 & -0.848 & 1.851 & 0.591 & 0.804 & low $\mathrm{NH}_{4}{ }^{+}$day $9(2)$ \\
\hline XUV & low $\mathrm{NH}_{4}{ }^{+} /+\mathrm{NH}_{4}{ }^{+} \mathrm{T}=6 \mathrm{~h}(1)$ & -50.000 & -125.000 & -15.385 & 75.000 & 34.615 & 0.024 & low $\mathrm{NH}_{4}{ }^{+}$day 9 (1) \\
\hline XUV & low $\mathrm{NH}_{4}{ }^{1} /+\mathrm{NH}_{4}{ }^{+} \mathrm{T}=6 \mathrm{~h}(2)$ & ND & - & - & - & - & - & low $\mathrm{NH}_{4}$ day 9 (2) \\
\hline XUV & low $\mathrm{NH}_{4}{ }^{+} /-\mathrm{NH}_{4}{ }^{1} \mathrm{~T}=24 \mathrm{~h} \mathrm{(1)}$ & -3.205 & -5.495 & -2.141 & 2.289 & 1.064 & 0.030 & low $\mathrm{NH}_{4}$ day $9(1)$ \\
\hline XUV & low $\mathrm{NH}_{4}{ }^{+} /-\mathrm{NH}_{4}{ }^{+} \mathrm{T}=24 \mathrm{~h}(2)$ & -3.155 & -5.495 & -1.718 & 2.340 & 1.436 & 0.181 & low $\mathrm{NH}_{4}{ }^{+}$day $9(2)$ \\
\hline XUV & low $\mathrm{NH}_{4}{ }^{1} /+\mathrm{NH}_{4}{ }^{+} \mathrm{T}=24 \mathrm{~h}(1)$ & -9.615 & -16.129 & -6.173 & 6.514 & 3.443 & 0.000 & low $\mathrm{NH}_{4}$ day 9 (1) \\
\hline XUV & low $\mathrm{NH}_{4}{ }^{\prime} /+\mathrm{NH}_{4}{ }^{+} \mathrm{T}=24 \mathrm{~h}(2)$ & -15.625 & -28.571 & -10.204 & 12.946 & 5.421 & 0.000 & low $\mathrm{NH}_{4}$ day $9(2)$ \\
\hline XUV & low $\mathrm{NH}_{4}{ }^{1} /-\mathrm{NH}_{4}{ }^{1} \mathrm{~T}=48 \mathrm{~h}(2)$ & -22.222 & -25.000 & -20.000 & 2.778 & 2.222 & 0.000 & low $\mathrm{NH}_{4}$ day 9 (1) \\
\hline XUV & low $\mathrm{NH}_{4}{ }^{+} /+\mathrm{NH}_{4}{ }^{+} \mathrm{T}=48 \mathrm{~h} \mathrm{(2)}$ & -13.699 & -33.333 & -5.587 & 19.635 & 8.112 & 0.176 & low $\mathrm{NH}_{4}$ day 9 (2) \\
\hline NAR 1.3 & low $\mathrm{NH}_{4}{ }^{+} /-\mathrm{NH}_{4}{ }^{+} \mathrm{T}=2 \mathrm{~h}(1)$ & 2.657 & 1.816 & 3.633 & 0.841 & 0.976 & 0.100 & low $\mathrm{NH}_{4}$ day $9(1)$ \\
\hline NAR 1.3 & low $\mathrm{NH}_{4}^{+} /-\mathrm{NH}_{4}^{+} \mathrm{T}=2 \mathrm{~h}(2)$ & 1.541 & 1.267 & 1.892 & 0.274 & 0.351 & 0.106 & low $\mathrm{NH}_{4}$, day 9 (2) \\
\hline NAR 1.3 & low $\mathrm{NH}_{4}{ }^{+} /+\mathrm{NH}_{4}{ }^{+} \mathrm{T}=2 \mathrm{~h}(1)$ & ND & - & - & - & - & - & low $\mathrm{NH}_{4}{ }^{\prime}$ day 9 (1) \\
\hline NAR 1.3 & low $\mathrm{NH}_{4}{ }^{+} /+\mathrm{NH}_{4}{ }^{+} \mathrm{T}=2 \mathrm{~h}(2)$ & -45.455 & -76.923 & -26.316 & 31.469 & 19.139 & 0.023 & low $\mathrm{NH}_{4}^{+}$day $9(2)$ \\
\hline NAR 1.3 & low $\mathrm{NH}_{4}{ }^{1} /-\mathrm{NH}_{4}{ }^{t} \mathrm{~T}=4 \mathrm{~h}(\mathrm{l})$ & 1.768 & 1.396 & 2.719 & 0.372 & 0.951 & 0.104 & low $\mathrm{NH}_{4}{ }^{1}$ day 9 (1) \\
\hline NAR 1.3 & low $\mathrm{NH}_{4}{ }^{+} /-\mathrm{NH}_{4}{ }^{+} \mathrm{T}=4 \mathrm{~h}(2)$ & -2.342 & -2.959 & -1.709 & 0.617 & 0.633 & 0.000 & low $\mathrm{NH}_{4}$ day $9(2)$ \\
\hline NAR 1.3 & low $\mathrm{NH}_{4}{ }^{1} /+\mathrm{NH}_{4}{ }^{1} \mathrm{~T}=4 \mathrm{~h}(\mathrm{I})$ & -9.434 & -10.638 & -8.130 & 1.204 & 1.304 & 0.000 & low $\mathrm{NH}_{4}$ day 9 (1) \\
\hline NAR 1.3 & low $\mathrm{NH}_{4}{ }^{\prime} /+\mathrm{NH}_{4}{ }^{+} \mathrm{T}=4 \mathrm{~h}(2)$ & -11.111 & -20.833 & -4.608 & 9.722 & 6.503 & 0.000 & low $\mathrm{NH}_{4}$ day $9(2)$ \\
\hline NAR 1.3 & low $\mathrm{NH}_{4}{ }^{\prime} /-\mathrm{NH}_{4}{ }^{+} \mathrm{T}=6 \mathrm{~h}(1)$ & -1.312 & -2.137 & -0.901 & 0.824 & 0.411 & 0.451 & low $\mathrm{NH}_{4}{ }^{1}$ day 9 (1) \\
\hline NAR 1.3 & low $\mathrm{NH}_{4}{ }^{1} /-\mathrm{NH}_{4}{ }^{1} \mathrm{~T}=6 \mathrm{~h}(2)$ & -2.358 & -3.135 & -1.818 & 0.776 & 0.540 & 0.103 & low $\mathrm{NH}_{4}$ day $9(2)$ \\
\hline NAR 1.3 & low $\mathrm{NH}_{4}{ }^{1} /+\mathrm{NH}_{4}{ }^{1} \mathrm{~T}=6 \mathrm{~h}(1)$ & -18.182 & -20.000 & -15.873 & 1.818 & 2.309 & 0.011 & low $\mathrm{NH}_{4}$ day $9(1)$ \\
\hline NAR 1.3 & low $\mathrm{NH}_{4}{ }^{1} /+\mathrm{NH}_{4}{ }^{+} \mathrm{T}=6 \mathrm{~h}(2)$ & -6.410 & -10.753 & -3.344 & 4.342 & 3.066 & 0.000 & low $\mathrm{NH}_{4}{ }^{1}$ day $9(2)$ \\
\hline NAR 1.3 & low $\mathrm{NH}_{4}{ }^{1} /-\mathrm{NH}_{4}{ }^{+} \mathrm{T}=24 \mathrm{~h}(1)$ & -1.486 & -3.704 & -0.611 & 2.218 & 0.875 & 0.550 & low $\mathrm{NH}_{4}$ day $9(1)$ \\
\hline NAR 1.3 & low $\mathrm{NH}_{4}{ }^{\prime} /-\mathrm{NH}_{4}{ }^{\prime} \mathrm{T}=24 \mathrm{~h}(2)$ & -1.376 & -3.378 & -0.333 & 2.003 & 1.042 & 0.709 & low $\mathrm{NH}_{4}$ day $9(2)$ \\
\hline NAR 1.3 & low $\mathrm{NH}_{4}{ }^{\prime} /+\mathrm{NH}_{4}{ }^{\prime} \mathrm{T}=24 \mathrm{~h}(1)$ & -1.159 & -2.151 & -0.752 & 0.992 & 0.406 & 0.698 & low $\mathrm{NH}_{4}$ day 9 (1) \\
\hline NAR 1.3 & low $\mathrm{NH}_{4}{ }^{+} /+\mathrm{NH}_{4}{ }^{+} \mathrm{T}=24 \mathrm{~h}(2)$ & -1.362 & -2.347 & -0.619 & 0.985 & 0.743 & 0.585 & low $\mathrm{NH}_{4}{ }^{1}$ day $9(2)$ \\
\hline NAR 1.3 & low $\mathrm{NH}_{4}{ }^{1} /-\mathrm{NH}_{4}{ }^{+} \mathrm{T}=48 \mathrm{~h}(1)$ & -1.309 & -2.137 & -0.894 & 0.828 & 0.415 & 0.392 & low $\mathrm{NH}_{4}$ day 9 (1) \\
\hline NAR 1.3 & low $\mathrm{NH}_{4}{ }^{1} /-\mathrm{NH}_{4}{ }^{\prime} \mathrm{T}=48 \mathrm{~h}$ (2) & 1.274 & 0.866 & 1.919 & 0.408 & 0.645 & 0.346 & low $\mathrm{NH}_{4}{ }^{+}$day 9 (2) \\
\hline NAR 1.3 & low $\mathrm{NH}_{4}{ }^{+} /+\mathrm{NH}_{4}{ }^{\prime} \mathrm{T}=48 \mathrm{~h}(1)$ & 1.052 & 0.927 & 1.227 & 0.125 & 0.175 & 0.424 & low $\mathrm{NH}_{4}{ }^{+}$day 9 (1) \\
\hline NAR 1.3 & low $\mathrm{NH}_{4}{ }^{1} /+\mathrm{NH}_{4}{ }^{+} \mathrm{T}=48 \mathrm{~h}(2)$ & -1.558 & -2.967 & -0.655 & 1.410 & 0.902 & 0.375 & low $\mathrm{NH}_{4}{ }^{+}$day $9(2)$ \\
\hline DUR2 & low $\mathrm{NH}_{4}{ }^{1} /-\mathrm{NH}_{4}{ }^{1} \mathrm{~T}=2 \mathrm{~h}(1)$ & 1.136 & 0.783 & 1.770 & 0.353 & 0.634 & 0.654 & low $\mathrm{NH}_{4}$ day $9(\mathrm{I})$ \\
\hline DUR2 & low $\mathrm{NH}_{4}{ }^{+} /-\mathrm{NH}_{4}{ }^{+} \mathrm{T}=2 \mathrm{~h}(2)$ & 2.090 & 1.403 & 2.952 & 0.687 & 0.862 & 0.106 & low $\mathrm{NH}_{4}{ }^{+}$day $9(2)$ \\
\hline DUR2 & low $\mathrm{NH}_{4}{ }^{+} /+\mathrm{NH}_{4}{ }^{1} \mathrm{~T}=2 \mathrm{~h}(1)$ & -5.882 & -8.264 & -3.155 & 2.382 & 2.728 & 0.000 & low $\mathrm{NH}_{4}$ day $9(1)$ \\
\hline DUR2 & low $\mathrm{NH}_{4}{ }^{1} /+\mathrm{NH}_{4}{ }^{+} \mathrm{T}=2 \mathrm{~h}(2)$ & -12.048 & -17.544 & -9.091 & 5.496 & 2.957 & 0.016 & low $\mathrm{NH}_{4}$ ' day $9(2)$ \\
\hline DUR2 & low $\mathrm{NH}_{4}{ }^{+} /-\mathrm{NH}_{4}{ }^{+} \mathrm{T}=4 \mathrm{~h}(1)$ & 1.190 & 0.752 & 1.681 & 0.438 & 0.491 & 0.430 & low $\mathrm{NH}_{4}{ }^{+}$day 9 (1) \\
\hline DUR2 & low $\mathrm{NH}_{4}{ }^{1} /-\mathrm{NH}_{4}{ }^{+} \mathrm{T}=4 \mathrm{~h}(2)$ & 1.113 & 0.732 & 1.879 & 0.381 & 0.766 & 0.000 & low $\mathrm{NH}_{4}{ }^{\prime}$ day $9(2)$ \\
\hline DUR2 & low $\mathrm{NH}_{4}{ }^{1} /+\mathrm{NH}_{4}{ }^{+} \mathrm{T}=4 \mathrm{~h}(1)$ & -8.772 & -11.765 & -7.299 & 2.993 & 1.473 & 0.000 & low $\mathrm{NH}_{4}$ day 9 (1) \\
\hline DUR2 & low $\mathrm{NH}_{4}{ }^{1} /+\mathrm{NH}_{4}{ }^{1} \mathrm{~T}=4 \mathrm{~h}(2)$ & -26.316 & -40.000 & -18.519 & 13.684 & 7.797 & 0.000 & low $\mathrm{NH}_{4}{ }^{\prime}$ day $9(2)$ \\
\hline DUR2 & low $\mathrm{NH}_{4} /-\mathrm{NH}_{4} \mathrm{~T}=6 \mathrm{~h}(1)$ & -1.522 & -2.020 & -1.302 & 0.498 & 0.220 & 0.069 & low $\mathrm{NH}_{4}$ day 9 (1) \\
\hline DUR2 & low $\mathrm{NH}_{4}{ }^{1} /-\mathrm{NH}_{4}{ }^{\prime} \mathrm{T}=6 \mathrm{~h}(2)$ & -1.357 & -2.793 & -0.531 & 1.436 & 0.826 & 0.544 & low $\mathrm{NH}_{4}$, day $9(2)$ \\
\hline DUR2 & low $\mathrm{NH}_{4}^{+} /+\mathrm{NH}_{4} \mathrm{~T}=6 \mathrm{~h}(1)$ & -4.566 & -7.576 & -3.205 & 3.010 & 1.361 & 0.000 & low $\mathrm{NH}_{4}$ day 9 (1) \\
\hline
\end{tabular}




\begin{tabular}{|c|c|c|c|c|c|c|c|c|}
\hline DUR2 & low $\mathrm{NH}_{4}{ }^{1} /+\mathrm{NH}_{4}{ }^{1} \mathrm{~T}=6 \mathrm{~h}(2)$ & -22.222 & -34.483 & -16.393 & 12.261 & 5.829 & 0.000 & low $\mathrm{NH}_{4}{ }^{+}$day $9(2)$ \\
\hline DUR2 & low $\mathrm{NH}_{4}{ }^{1} /-\mathrm{NH}_{4}{ }^{+} \mathrm{T}=24 \mathrm{~h}$ (1) & -2.336 & -3.534 & -1.531 & 1.197 & 0.805 & 0.000 & low $\mathrm{NH}_{4}{ }^{+}$day 9 (1) \\
\hline DUR2 & low $\mathrm{NH}_{4}{ }^{\dagger} /-\mathrm{NH}_{4}{ }^{\top} \mathrm{T}=24 \mathrm{~h}(2)$ & -2.817 & -8.000 & -1.021 & 5.183 & 1.795 & 0.232 & low $\mathrm{NH}_{4}{ }^{+}$day $9(2)$ \\
\hline DUR2 & low $\mathrm{NH}_{4}{ }^{+} /+\mathrm{NH}_{4}{ }^{+} \mathrm{T}=24 \mathrm{~h}(1)$ & -2.088 & -4.149 & -1.110 & 2.062 & 0.978 & 0.000 & low $\mathrm{NH}_{4}{ }^{\prime}$ day $9(1)$ \\
\hline DUR2 & low $\mathrm{NH}_{4}{ }^{1} /+\mathrm{NH}_{4}{ }^{1} \mathrm{~T}=24 \mathrm{~h}(2)$ & -8.850 & -13.158 & -5.587 & 4.308 & 3.263 & 0.007 & low $\mathrm{NH}_{4}{ }^{+}$day $9(2)$ \\
\hline DUR2 & low $\mathrm{NH}_{4}{ }^{+} /-\mathrm{NH}_{4}{ }^{+} \mathrm{T}=48 \mathrm{~h}(1)$ & -2.717 & -3.448 & -1.855 & 0.731 & 0.862 & 0.000 & low $\mathrm{NH}_{4}^{+}$day $9(1)$ \\
\hline DUR2 & low $\mathrm{NH}_{4}{ }^{+} /-\mathrm{NH}_{4}{ }^{+} \mathrm{T}=48 \mathrm{~h}(2)$ & -2.128 & -8.130 & -0.770 & 6.002 & 1.358 & 0.123 & low $\mathrm{NH}_{4}{ }^{+}$day 9 (2) \\
\hline DUR2 & low $\mathrm{NH}_{4}{ }^{1} /+\mathrm{NH}_{4}{ }^{+} \mathrm{T}=48 \mathrm{~h}(1)$ & -2.525 & -3.636 & -1.502 & 1.111 & 1.024 & 0.071 & low $\mathrm{NH}_{4}{ }^{\prime}$ day 9 (1) \\
\hline DUR2 & low $\mathrm{NH}_{4}{ }^{1} /+\mathrm{NH}_{4}^{+} \mathrm{T}=48 \mathrm{~h}(2)$ & -6.173 & -11.111 & -3.584 & 4.938 & 2.589 & 0.000 & low $\mathrm{NH}_{4}{ }^{+}$day 9 (2) \\
\hline FMD2 & low $\mathrm{NH}_{4}{ }^{1} /-\mathrm{NH}_{4}{ }^{\dagger} \mathrm{T}=2 \mathrm{~h}(1)$ & 2.086 & 1.236 & 3.545 & 0.850 & 1.459 & 0.000 & low $\mathrm{NH}_{4}{ }^{+}$day 9 (1) \\
\hline FMD2 & low $\mathrm{NH}_{4}{ }^{1} /-\mathrm{NH}_{4}{ }^{+} \mathrm{T}=2 \mathrm{~h}(2)$ & -1.175 & -1.859 & -0.668 & 0.684 & 0.508 & 0.704 & low $\mathrm{NH}_{4}{ }^{\prime}$ day 9 (2) \\
\hline FMD2 & low $\mathrm{NH}_{4}{ }^{+} /+\mathrm{NH}_{4}{ }^{+} \mathrm{T}=2 \mathrm{~h}(1)$ & ND & - & - & - & - & - & low $\mathrm{NH}_{4}{ }^{+}$day 9 (1) \\
\hline FMD2 & low $\mathrm{NH}_{4}^{+} /+\mathrm{NH}_{4}{ }^{+} \mathrm{T}=2 \mathrm{~h}(2)$ & -35.714 & -55.556 & -20.833 & 19.841 & 14.881 & 0.000 & low $\mathrm{NH}_{4}{ }^{+}$day 9 (2) \\
\hline FMD2 & low $\mathrm{NH}_{4}{ }^{1} /-\mathrm{NH}_{4} \mathrm{~T}=4 \mathrm{~h}(1)$ & 3.816 & 2.585 & 6.546 & 1.231 & 2.730 & 0.040 & low $\mathrm{NH}_{4}{ }^{+}$day $9(1)$ \\
\hline FMD2 & low $\mathrm{NH}_{4}^{+} /-\mathrm{NH}_{4}^{+} \mathrm{T}=4 \mathrm{~h}(2)$ & 1.792 & 1.051 & 3.337 & 0.741 & 1.545 & 0.195 & low $\mathrm{NH}_{4}{ }^{+}$day $9(2)$ \\
\hline FMD2 & low $\mathrm{NH}_{4}{ }^{+} /+\mathrm{NH}_{4}{ }^{+} \mathrm{T}=4 \mathrm{~h}(1)$ & ND & - & - & - & - & - & low $\mathrm{NH}_{4}{ }^{+}$day $9(1)$ \\
\hline FMD2 & low $\mathrm{NH}_{4}{ }^{1} /+\mathrm{NH}_{4}{ }^{+} \mathrm{T}=4 \mathrm{~h}(2)$ & ND & - & - & - & - & - & low $\mathrm{NH}_{4}{ }^{+}$day $9(2)$ \\
\hline FMD2 & low $\mathrm{NH}_{4} 1 /-\mathrm{NH}_{4}{ }^{+} \mathrm{T}=6 \mathrm{~h}(1)$ & -1.508 & -2.364 & -0.935 & 0.856 & 0.574 & 0.340 & low $\mathrm{NH}_{4}{ }^{+}$day 9 (1) \\
\hline FMD2 & low $\mathrm{NH}_{4}{ }^{1} /-\mathrm{NH}_{4} \mathrm{~T}=6 \mathrm{~h}(2)$ & -2.584 & -5.495 & -1.297 & 2.911 & 1.287 & 0.128 & low $\mathrm{NH}_{4}{ }^{+}$day 9 (2) \\
\hline FMD2 & low $\mathrm{NH}_{4}{ }^{i} /+\mathrm{NH}_{4}{ }^{i} \mathrm{~T}=6 \mathrm{~h}(1)$ & -7.937 & -18.868 & -3.378 & 10.931 & 4.558 & 0.000 & low $\mathrm{NH}_{4}{ }^{+}$day 9 (1) \\
\hline FMD2 & low $\mathrm{NH}_{4}{ }^{+}+\mathrm{NH}_{4}{ }^{+} \mathrm{T}=6 \mathrm{~h}(2)$ & ND & - & 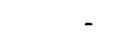 & - & - & - & low $\mathrm{NH}_{4}{ }^{+}$day 9 (2) \\
\hline FMD2 & low $\mathrm{NH}_{4}{ }^{+} /-\mathrm{NH}_{4}{ }^{i} \mathrm{~T}=24 \mathrm{~h}(1)$ & ND & - & & - & - & - & low $\mathrm{NH}_{4}{ }^{+}$day $9(1)$ \\
\hline FMD2 & low $\mathrm{NH}_{4}{ }^{1} /-\mathrm{NH}_{4}{ }^{1} \mathrm{~T}=24 \mathrm{~h}(2)$ & -1.282 & -10.101 & -0.163 & 8.819 & 1.119 & 0.839 & low $\mathrm{NH}_{4}{ }^{\prime}$ day $9(2)$ \\
\hline FMD2 & low $\mathrm{NH}_{4}{ }^{\dagger} /+\mathrm{NH}_{4}{ }^{i} \mathrm{~T}=24 \mathrm{~h}(1)$ & ND & - & - & - & - & - & low $\mathrm{NH}_{4}{ }^{+}$day 9 (1) \\
\hline FMD2 & low $\mathrm{NH}_{4}+1+\mathrm{NH}_{4} \mathrm{~T}=24 \mathrm{~h}(2)$ & ND & - & - & - & - & - & low $\mathrm{NH}_{4}$ day $9(2)$ \\
\hline FMD2 & low $\mathrm{NH}_{4}^{+} /-\mathrm{NH}_{4}{ }^{\prime} \mathrm{T}=48 \mathrm{~h}(1)$ & 1.926 & 1.040 & 2.719 & 0.886 & 0.793 & 0.148 & low $\mathrm{NH}_{4}$ day 9 (1) \\
\hline FMD2 & low $\mathrm{NH}_{4}{ }^{1} /-\mathrm{NH}_{4}{ }^{1} \mathrm{~T}=48 \mathrm{~h}(2)$ & 1.152 & 0.607 & 2.582 & 0.545 & 1.430 & 0.684 & low $\mathrm{NH}_{4}{ }^{+}$day 9 (2) \\
\hline FMD2 & low $\mathrm{NH}_{4}{ }^{\prime}+\mathrm{NH}_{4}{ }^{+} \mathrm{T}=48 \mathrm{~h}(1)$ & ND & - & $\begin{array}{ll}- & -1 \\
-1\end{array}$ & - & - & - & low $\mathrm{NH}_{4}{ }^{+}$day 9 (1) \\
\hline FMD2 & low $\mathrm{NH}_{4} /+\mathrm{NH}_{4} \mathrm{~T}=48 \mathrm{~h} \mathrm{(2)}$ & ND & - & - & - & - & - & low $\mathrm{NH}_{4}{ }^{+}$day $9(2)$ \\
\hline
\end{tabular}

${ }^{\prime} \mathrm{ND}$ : Not detected, meaning the $\mathrm{C}_{\mathrm{T}}$ values were higher than the effective efficiency range for the primers or no amplification occurred at all. 


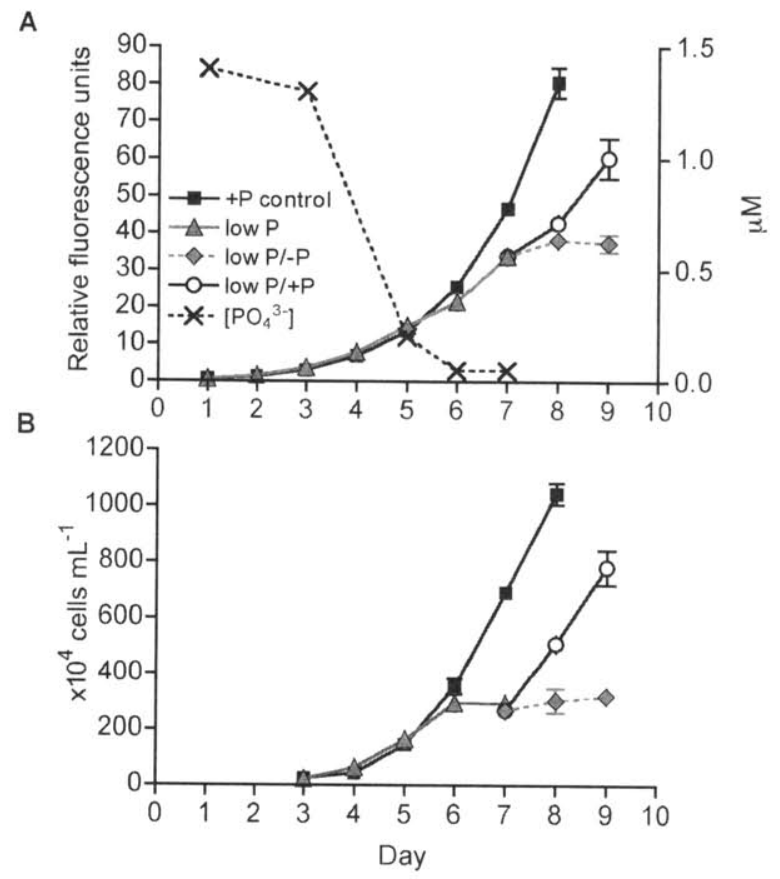

Figure 1. Growth of $A$. anophagefferens in phosphorus replete $(+\mathrm{P}$ control) and low phosphorus (low P) conditions tracked by (A) fluorescence and (B) cell concentration. On day 7, low $\mathrm{P}$ cells were pooled and redistributed. Phosphorus was re-supplied to two cultures (low $\mathrm{P} /+\mathrm{P}$ ) while two were left unchanged (low $\mathrm{P} /-\mathrm{P}$ ). Error bars represent standard error of the mean of 3 biological replicates for the $+\mathrm{P}$ control, 4 biological replicates for the low $\mathrm{P}$, and 2 biological replicates for both low $\mathrm{P} /-\mathrm{P}$ and low $\mathrm{P} /+\mathrm{P}$. External phosphate concentrations are also plotted in panel (A) with error bars representing standard error of the mean of two biological replicates. 


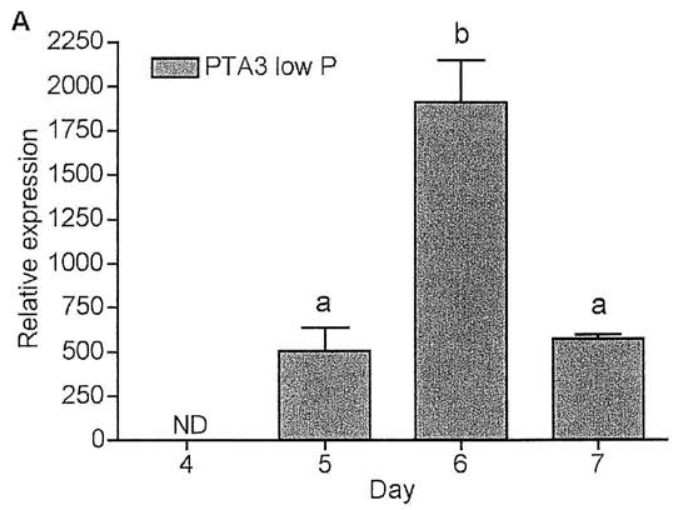

B

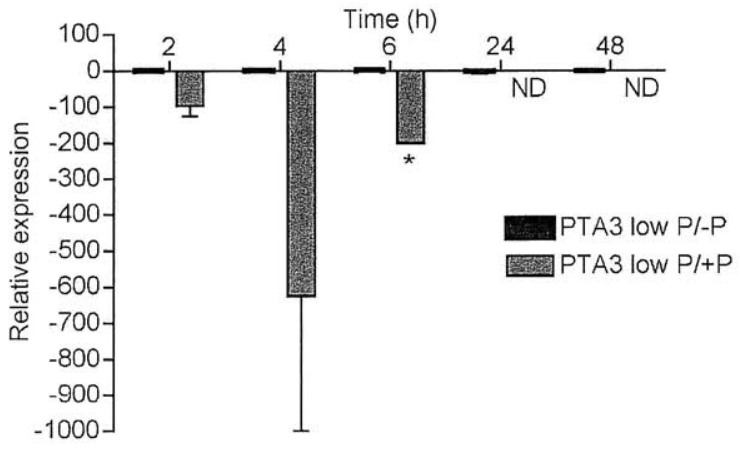

Figure 2. Bar graph comparing the expression of a phosphate transporter (PTA3) over the course of the (A) low $\mathrm{P}$ and (B) $\mathrm{P}$ re-addition experiments: top low $\mathrm{P} / \mathrm{-P}$ and bottom low $\mathrm{P} /+\mathrm{P}$. Transcript data are plotted as average fold-change relative to a reference condition using the comparative $\mathrm{C}_{\mathrm{T}}$ method for qRT-PCR with a reference gene that encodes a ubiquitin-conjugating enzyme. Error bars specify standard error of the average fold change of duplicate biological samples between the sample conditions and the reference condition. Letters indicate statistical difference $(P$-value $<0.05)$ based upon a one-way ANOVA Tukey post test (e.g "a" is different than "b"). The reference condition for the low $\mathrm{P}$ condition was exponentially growing $\mathrm{P}$ replete cells (+P control). The reference condition for the $\mathrm{P}$ re-addition conditions was $\mathrm{T}_{0}$ (low $\mathrm{P}$ cells day 7). An asterisk (*) indicates that the transcript was only detected in one biological replicate. ND means the transcript was not detected. In graph (B), the data were not significantly different from each other, so no letters are shown. 
A

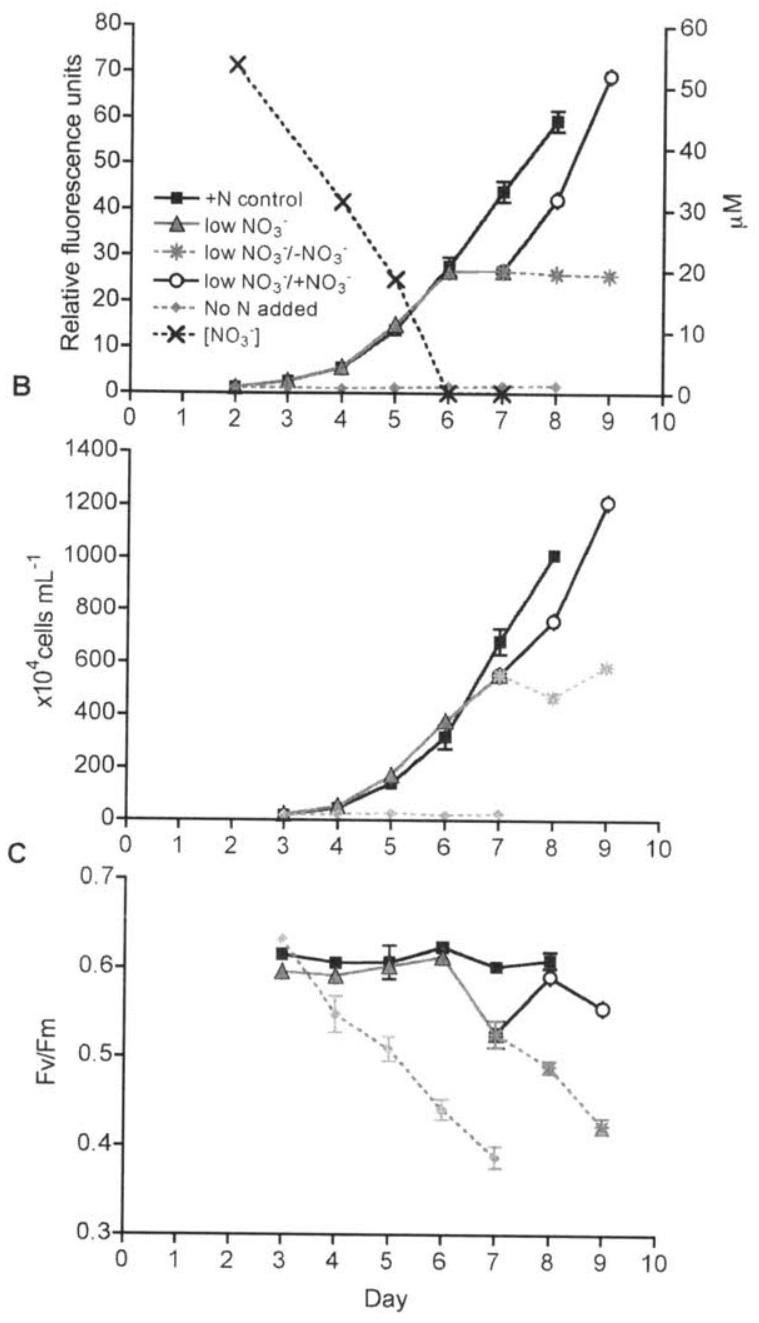

Figure 3. Growth of $A$. anophagefferens under nitrate replete $(+\mathrm{N}$ control), low nitrate (low $\mathrm{NO}_{3}{ }^{-}$), and no nitrogen added (no $\mathrm{N}$ added) conditions tracked by (A) fluorescence and (B) cell concentration. The $\mathrm{F}_{\mathrm{v}} / \mathrm{F}_{\mathrm{m}}$ ratio was also tracked in all conditions $(\mathrm{C})$. On day 7 , low $\mathrm{NO}_{3}{ }^{-}$cells were pooled and redistributed. Nitrate was re-supplied to two cultures (low $\mathrm{NO}_{3}{ }^{-} /+\mathrm{NO}_{3}{ }^{-}$) while two were left unchanged (low $\mathrm{NO}_{3}{ }^{-} /-\mathrm{NO}_{3}^{-}$). Error bars represent standard error of the mean of 3 biological replicates for the $+\mathrm{N}$ control, low $\mathrm{NO}_{3}{ }_{3}$, and no $\mathrm{N}$ added conditions and 2 biological replicates for both low $\mathrm{NO}_{3}{ }^{-} /-\mathrm{NO}_{3}{ }^{-}$and low $\mathrm{NO}_{3}{ }^{-} /+\mathrm{NO}_{3}{ }^{-}$conditions. External nitrate concentrations are also plotted in panel (A) with error bars representing standard error of the mean of two biological replicates. 


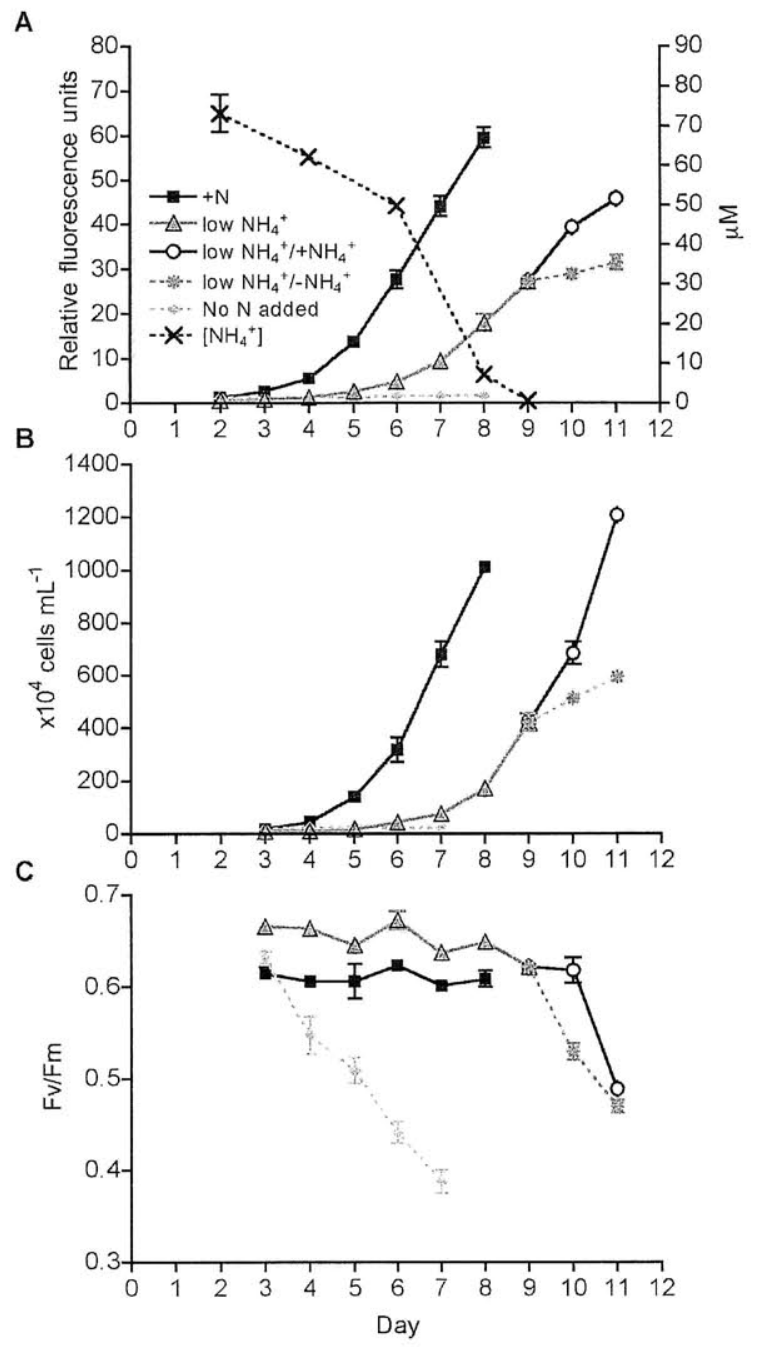

Figure 4. Growth of $A$. anophagefferens under nitrogen replete ( $+\mathrm{N}$ control), low ammonium (low $\mathrm{NH}_{4}{ }^{+}$), and no nitrogen added (no $\mathrm{N}$ added) conditions tracked by (A) fluorescence and (B) cell concentration. The $\mathrm{F}_{\mathrm{v}} / \mathrm{F}_{\mathrm{m}}$ ratio was also tracked in all conditions (C). On day 9, low $\mathrm{NH}_{4}^{+}$cells were pooled and redistributed. Ammonium was re-supplied to two cultures (low $\mathrm{NH}_{4}{ }^{+} /+\mathrm{NH}_{4}{ }^{+}$) while two were left unchanged (low $\mathrm{NH}_{4}^{+} /-\mathrm{NH}_{4}^{+}$). Error bars represent standard error of the mean of 3 biological replicates for the $+\mathrm{N}$ control, low $\mathrm{NH}_{4}{ }^{+}$, and no $\mathrm{N}$ added conditions and 2 biological replicates for both low $\mathrm{NH}_{4}{ }^{+} /-\mathrm{NH}_{4}{ }^{+}$and low $\mathrm{NH}_{4}{ }^{+} /+\mathrm{NH}_{4}{ }^{+}$conditions. External ammonium concentrations are also plotted in panel (A) with error bars representing standard error of the mean of two biological replicates. 

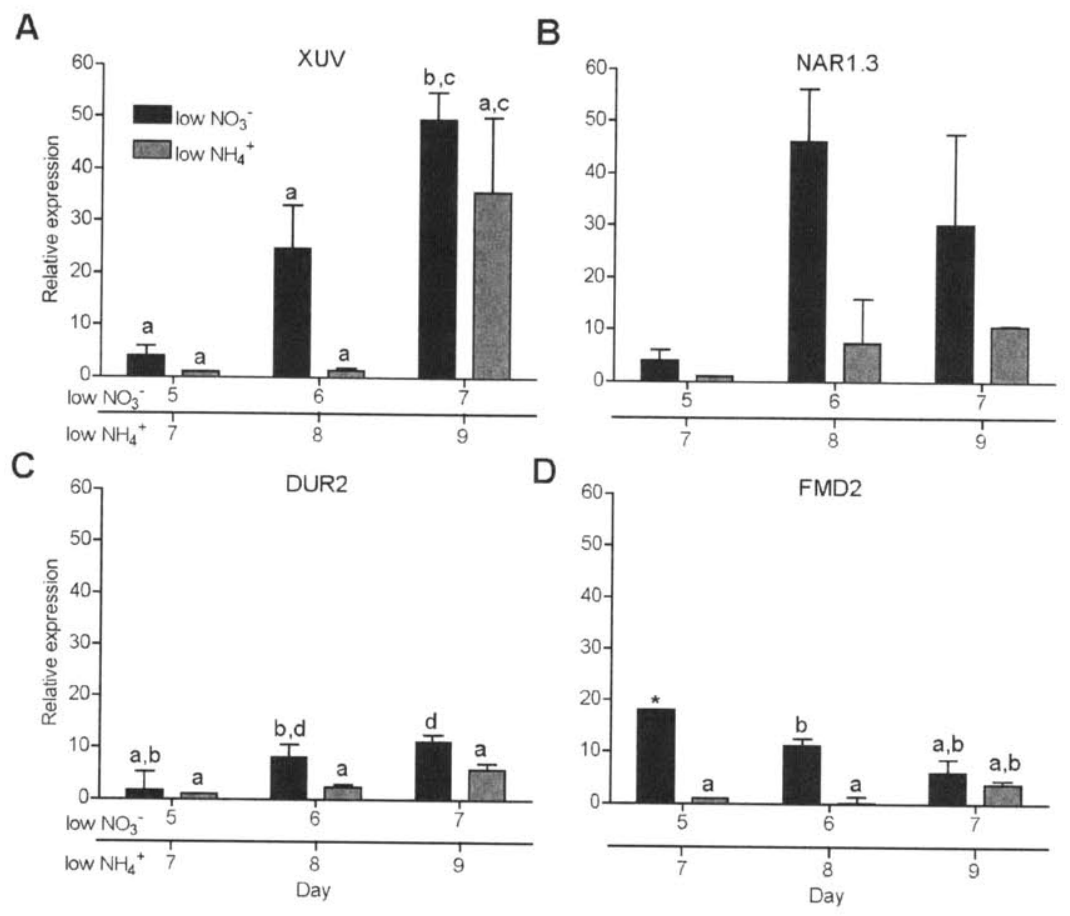

Figure 5. Bar graph comparing the expression of (A) xanthine/uracil/vitamin $\mathrm{C}$ permease (XUV), (B) Formate/nitrite transporter (NAR1.3), (C) urea transporter (DUR2), and an acetamidase/formamidase (FMD2) over the course of the low $\mathrm{NO}_{3}{ }^{-}$and low $\mathrm{NH}_{4}{ }^{+}$ experiments. Transcript data are plotted as average fold-change relative to a reference condition using the comparative $C_{T}$ method for qRT-PCR with a reference gene that encodes a ubiquitin-conjugating enzyme. Error bars specify standard error of the average fold change of duplicate biological samples between the sample conditions and the reference condition. Letters indicate statistical difference $(P$-value $<0.05)$ based upon a one-way ANOVA Tukey post test (e.g. "a" is different than "b"). The reference condition for all samples was exponentially growing cells on ammonium (low $\mathrm{NH}_{4}{ }^{+}$day 7). An asterisk $(*)$ indicates that the transcript was only detected in one biological replicate. In graph (B), the data were not significantly different than each other, so no letters are shown. 

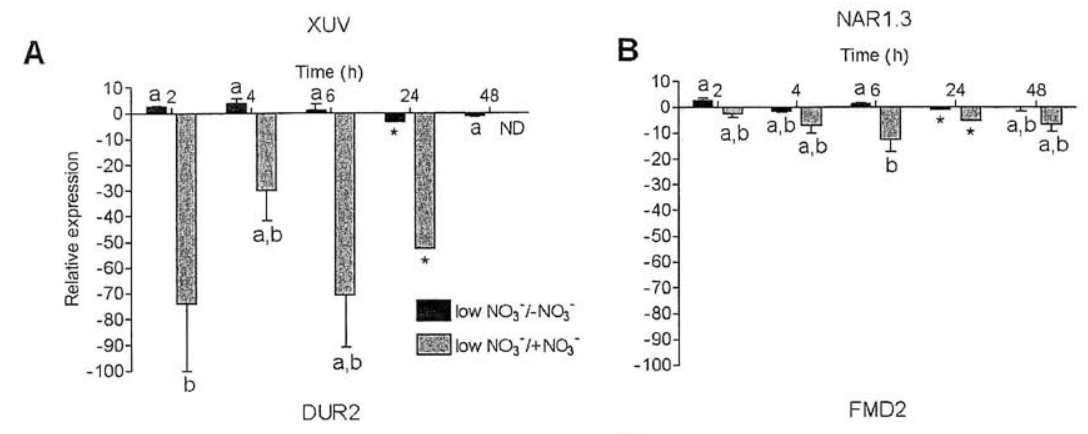

C
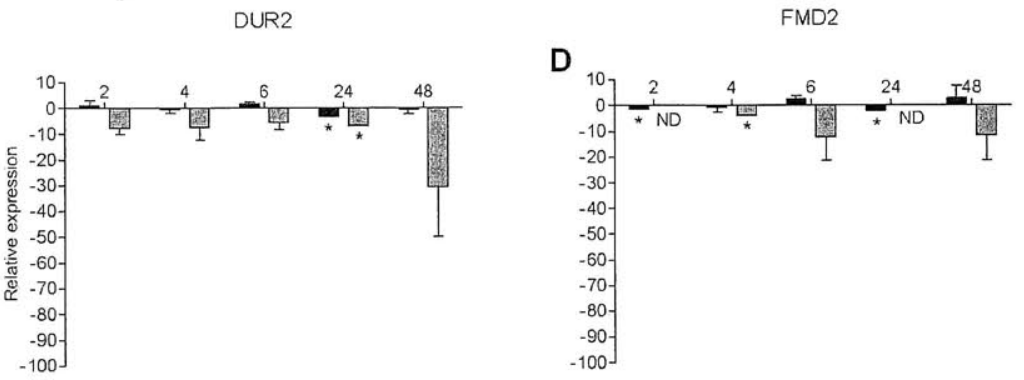

Figure 6. Bar graph comparing the expression of (A) xanthine/uracil/vitamin C permease (XUV), (B) Formate/nitrite transporter (NAR1.3), (C) urea transporter (DUR2), and an acetamidase/formamidase (FMD2) over the course of the nitrate re-addition experiment. Black bars indicate cells that were not refed nitrate while gray bars indicate cells that were re-supplied with nitrate. Transcript data are plotted as average fold-change relative to a reference condition using the comparative $\mathrm{C}_{\mathrm{T}}$ method for qRT-PCR with a reference gene that encodes a ubiquitin-conjugating enzyme. Error bars specify standard error of the average fold change of duplicate biological samples between the sample conditions and the reference condition. Letters indicate statistical difference $(P$-value $<0.05)$ based upon a one-way ANOVA Tukey post test (e.g. "a" is different than "b"). The reference condition for all samples was $\mathrm{N}$-deficient cells grown on nitrate at $\mathrm{T}_{0}$ (low $\mathrm{NO}_{3}{ }^{-}$day 7 ). An asterisk $\left(^{*}\right)$ indicates that the transcript was only detected in one biological replicate. ND means the transcript was not detected. In graphs (C) and (D), the data were not significantlv different from each other. so no letters are shown. 
A
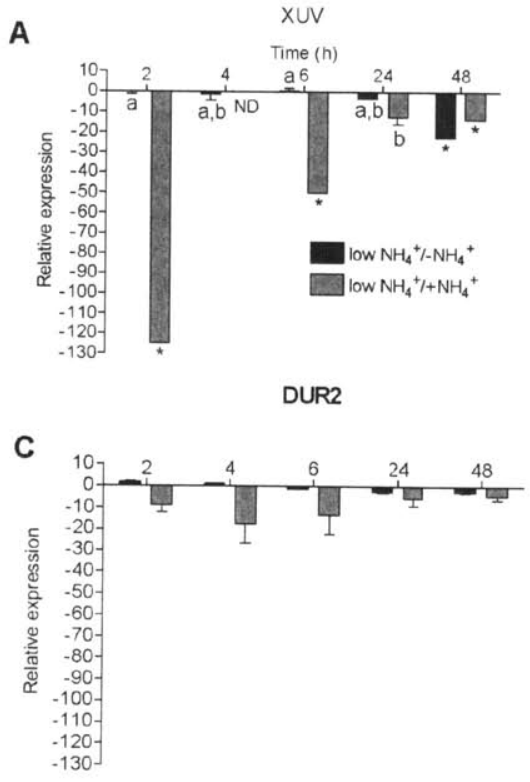

B
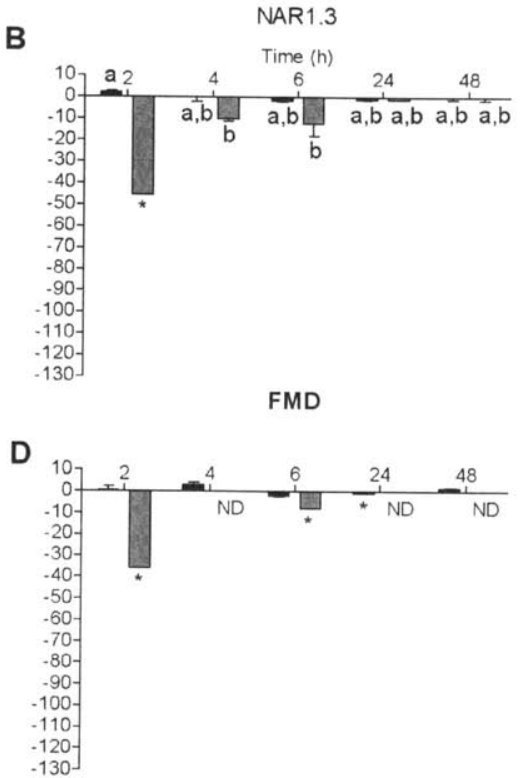

Figure 7. Bar graph comparing the expression of (A) xanthine/uracil/vitamin C permease (XUV), (B) Formate/nitrite transporter (NAR1.3), (C) urea transporter (DUR2), and an acetamidase/formamidase (FMD2) over the course of the ammonium re-addition experiment. Black bars indicate cells that were not refed ammonium while gray bars indicate cells that were re-supplied with ammonium. Transcript data are plotted as average fold-change relative to a reference condition using the comparative $C_{T}$ method for qRT-PCR with a reference gene that encodes a ubiquitin-conjugating enzyme. Error bars specify standard error of the average fold change of duplicate biological samples between the sample conditions and the reference condition. Letters indicate statistical difference $(P$-value $<0.05)$ based upon a one-way ANOVA Tukey post test (e.g. "a" is different than "b"). The reference condition for all samples was N-deficient cells grown on ammonium at $\mathrm{T}_{0}$ (low $\mathrm{NH}_{4}^{+}$day 7 ). An asterisk $(*)$ indicates that the transcript was only detected in one biological replicate. ND means the transcript was not detected. In graphs (B) and (D), the data were not significantly different from each other, so no letters are shown. 


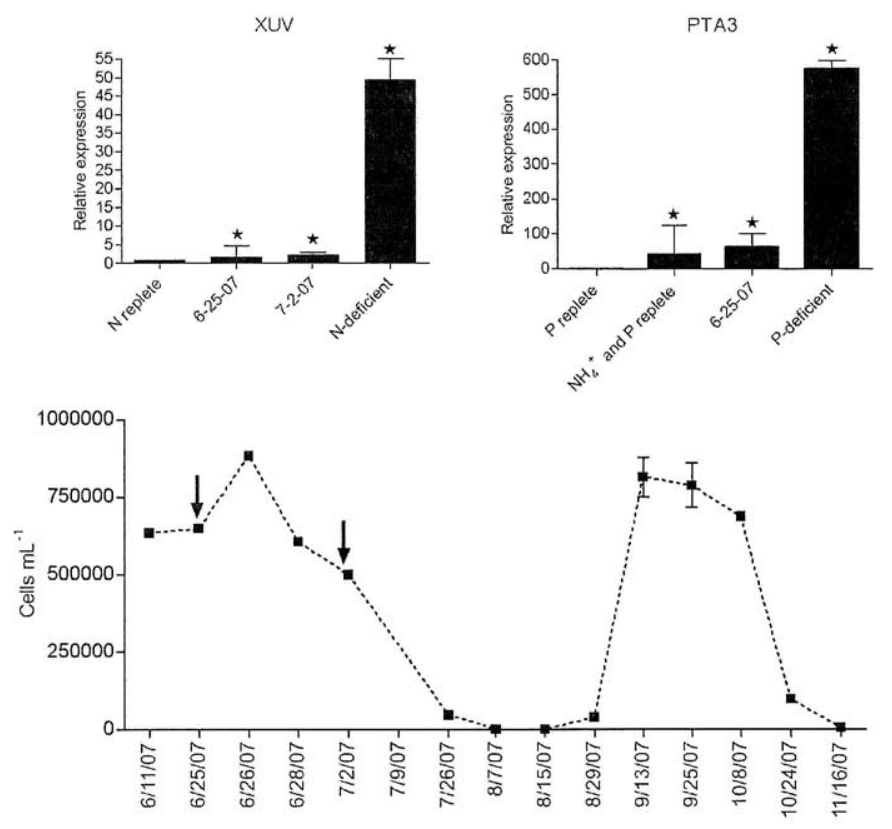

Figure 8. Bar graph comparing the expression of xanthine/uracil/vitamin C permease (XUV: upper left panel) and phosphate transporter (PTA3: upper right panel) from field samples taken during a 2007 brown tide bloom in Quantuck Bay (Suffolk County, NY). For comparison, XUV expression from N-replete and N-deficient conditions are plotted. PTA3 expression in $\mathrm{P}$ replete, ammonium grown $\mathrm{P}$ replete, and $\mathrm{P}$-deficient conditions are plotted for comparison as well. Transcript data are plotted as average fold-change relative to a reference condition using the comparative $\mathrm{C}_{\mathrm{T}}$ method for $\mathrm{qRT}$-PCR with a reference gene that encodes a ubiquitin-conjugating enzyme. Error bars specify standard error of the average fold change of duplicate biological samples between the sample conditions and the reference condition. The reference condition for all samples was $\mathrm{N}$ deficient cells grown on ammonium at $\mathrm{T}_{0}$ (low NH $4^{+}$day 7 ). A star ( $\star$ ) indicates that the fold change was significantly higher than the reference condition $(P$-value of less than 0.05) based upon a pair-wise fixed reallocation randomization analysis. $A$. anophagefferens cell densities over the course of the bloom are shown on the bottom panel. Arrows indicate the dates that were sampled for expression. 


\section{References:}

Berg, G. M., Glibert, P.M., Lomas, M.W., and Burford, M.A. (1997) Organic nitrogen uptake and growth by the chrysophyte Aureococcus anophagefferens during a brown tide event. Mar. Biol. 129: 377-387.

Berg, G.M., Repeta, D.J., and LaRoche, J. (2002) Dissolved organic nitrogen hydrolysis rates in axenic cultures of Aureococcus anophagefferens (Pelagophyceae): comparison with heterotrophic bacteria. Appl. Environ. Microbiol. 68: 401-404.

Berg, G.M., Repeta, D.J., and LaRoche, J. (2003) The role of the picoeukaryote Aureococcus anophagefferens in cycling of marine high-molecular weight dissolved organic nitrogen. Limnol. Oceanogr. 48: 1825-1830.

Berg, G.M., Shrager, J., Glockner, G., Arrigo, K.R., and Grossman, A.R. (2008) Understanding nitrogen limitation in Aureococcus anophagefferens (Pelagophyceae) through cDNA and qRT-PCR analysis. J. Phycol. 44: 1235-1249.

Chung CC, Hwang SPL, Chang J (2003) Identification of a high affinity phosphate transporter gene in a prasinophyte alga, Tetraselmis chui, and its expression under nutrient limitation. Appl. Environ. Microbiol. 69: 754-759.

Dyhrman ST, Haley ST, Birkeland SR, Wurch LL, Cipriano MJ et al. (2006) Long Serial Analysis of Gene Expression for gene discovery and transcriptome profiling in the widespread marine coccolithophore Emiliania huxleyi. Appl. Environ. Microbiol. 72: 252-260.

Dyhrman, S.T. (2008) Molecular approaches to diagnosing nutritional physiology in harmful algae: Implications for studying the effects of eutrophication. Harmful Algae 8: $167-174$.

Dzurica, S., Lee, C., Cosper, E.M., and Carpenter, E.J. (1989) Role of environmental variables, specifically organic compounds and nutrients, in the growth of the chrysophyte Aureococcus anophagefferens. p. 229-252. In E.M. Cosper, V.M. Bricelj, and E.J. Carpenter (eds.), Novel Phytoplankton Blooms: Causes and Impacts of Recurrent Brown Tides and Other Unusual Blooms, Volume 35. Springer, New York.

Gobler, C.J., and Sañudo-Wilhelmy, S.A. (2001) Effects of organic carbon, organic nitrogen, inorganic nutrients, and iron additions on the growth of phytoplankton and bacteria during a brown tide bloom. Mar. Ecol. Prog. Ser. 209: 19-34.

Gobler, C. J., Renaghan, M.J., and Buck, N.J. (2002) Impacts of nutrients and grazing mortality on the abundance of Aureococcus anophagefferens during a New York brown tide bloom. Limnol. Oceanogr. 47: 129-141. 
Gobler, C. J., Boneillo, G.E., Debenham, C., and Caron, D.A. (2004) Nutrient limitation, organic matter cycling, and plankton dynamics during an Aureococcus anophagefferens bloom in Great South Bay, N.Y. Aquat. Microb. Ecol. 35: 31-43.

Gobler, C. J., Lonsdale, D.J., and Boyer, G.L. (2005) A review of the causes, effects, and potential management of harmful brown tide blooms caused by Aureococcus anophagefferens (Hargraves et Sieburth). Estuaries 28: 726-749.

Gobler, C.J., Berry, D.L., Dyhrman, S.T., Wilhelm, S.W., Salamov, A. et al. (2011) Niche of harmful algal Aureococcus anophagefferens revealed through ecogenomics. 108: $4352-4357$.

Guillard R.R.L. and Hargraves P.E. (1993) Stichochrysis immobilis is a diatom, not a chrysophyte. Phycologia 32: 234-236.

LaRoche, J., Nuzzi, R., Waters, R., Wyman, K., Falkowski, P.G., and Wallace, D.W.R. (1997) Brown tide blooms in Long Island's coastal waters linked to variability in groundwater flow. Glob. Change Biol. 3: 397-410.

Le Bihan, T., Martin, S.F., Chirnside, E.S., van Ooijen, G., Barrios-Llerena, M.E. et al. (2011) Shotgun proteomics analysis of the unicellular alga Ostreococcus tauri. J. Prot. doi:10.1016/j.jprot.2011.05.028

Lomas, M.W., Glibert, P.M., and Berg, G.M. (1996) Characterization of nitrogen uptake by natural populations of Aureococcus anophagefferens (Chrysophyceae) as a function of incubation duration, substrate concentration, light, and temperature. J. Phycol. 32: 907916.

MacIntyre, H.L., Lomas, M.W., Cornwell, J.C., Suggett, D., Gobler, C.J., Koch, E., and Kana, T.M. (2004) Mediation of benthic-pelagic coupling by microphytobenthos: an energy and nutrient based model for initiation of blooms of Aureococcus anophagefferens. Harmful Algae 3: 403-437.

Mock T., Samanta M.P., Iverson V., Berthiaume C., Robison M., Holtermann K., et al. (2008) Whole genome expression profiling of the marine diatom Thalassiosira pseudonana identifies genes involved in silicon bioprocesses. Proc. Nat. Acad. Sci. U.S.A. 105:1579-1584.

Mulholland, M.R., Gobler, C.J., and Lee, C. (2002) Peptide hydrolysis, amino acid oxidation and $\mathrm{N}$ uptake in communities seasonally dominated by Aureococcus anophagefferens. Limnol. Oceanogr. 47: 1094-1108. 
Mulholland, M.R., Boneillo, G., and Minor E.C. (2004) A comparison of N and C uptake during brown tide (Aureococcus anophagefferens) blooms from two coastal bays on the east coast of the USA. Harmful Algae. 3: 361-376.

Palenik, B., and Henson S.E. (1997) The use of amides and other organic nitrogen sources by the phytoplankton Emiliania huxleyi. Limnol. Oceanogr. 42: 1544-1551.

Parkhill J., Maillet, G., and Cullen, J.J. (2001) Fluorescence-based maximal quantum yield for PSII as a diagnostic of nutrient stress. J. Phycol. 37: 517-529.

Pustizzi, F., MacIntyre, H.L., Warner, M.E., and Hutchins, D.A. (2004) Interaction of nitrogen source and light intensity on the growth and photosynthesis of the brown tide alga Aureococcus anophagefferens. Harmful Algae 3: 343-360.

Stauffer, B.A., Schaffner R.A., Wazniak, C. and Caron, D.A. (2008) Immunofluorescence flow cytometry technique for enumeration of the brown-tide alga, Aureococcus anophagefferens. Appl. Environ. Microbiol. 74: 6931-6940.

Sunda, W.G., Graneli, E., and Gobler, C.J. (2006) Positive feedback and the development and persistence of ecosystem disruptive algal blooms. J. Phycol. 42: 963-974.

Wurch L.L., Haley S.T., Orchard E.D., Gobler C.J., and Dyhrman S.T. (2011) Nutrientregulated transcriptional responses in the brown tide forming algal Aureococcus anophagefferens. Environ. Microbiol. 13: 468-481. 


\section{CHAPTER 5}

\section{Summary and Future Directions}

\section{Summary}

Phytoplankton in the world's oceans form the base of the marine food web and play a significant role in climate regulation and nutrient cycling. Therefore, studying the controls on phytoplankton growth and distribution remains a critical area of research in biological oceanography. A component of this research entails how different species of phytoplankton partition themselves into distinct niches that allow them to co-exist, or in some cases, how one phytoplankton species can gain a competitive advantage over all cooccurring phytoplankton leading to a monospecific or near monospecific bloom.

Aureococcus anophagefferens is a species of phytoplankton that has the capability of completely dominating the coastal systems where it occurs, often to the complete exclusion of other phytoplankton species (Gobler et al. 2005, Sunda et al. 2006). Therefore, A. anophagefferens serves as an excellent model for studying nutrient acquisition strategies that allow it to gain a competitive advantage. Due to the harmful nature of $A$. anophagefferens blooms, it is also imperative to determine the nutritional controls on $A$. anophagefferens growth in its natural setting. However, it is difficult to link nutrient supply to the growth of an individual species within a mixed assemblage of microorganisms as traditional metrics of phytoplankton nutrition rely upon community level assays such as bulk uptake rates and elemental composition (Dyhrman 2008). Molecular techniques offer the ability to target the physiology on an individual species, 
even in the presence of other microorganisms. In this thesis, I utilized a range of techniques to study the molecular underpinnings of nutrient acquisition in $A$. anophagefferens and develop a method for assaying nitrogen $(\mathrm{N})$ and phosphorus $(\mathrm{P})$ controls on $A$. anophagefferens growth in situ.

In the first data chapter (Chapter 2), I profiled the global transcriptional patterns of $A$. anophagefferens under nitrogen $(\mathrm{N})$ and phosphorus $(\mathrm{P})$ deficiency. The goal was to understand how $A$. anophagefferens adjusts the expression of its genome when inorganic $\mathrm{N}$ and $\mathrm{P}$ are unavailable. Results demonstrated that A. anophagefferens exhibits a broad transcriptional response to both $\mathrm{N}$ and $\mathrm{P}$ deficiency. When $\mathrm{N}$ is deficient, $A$. anophagefferens up-regulates genes involved in reduced and organic $\mathrm{N}$ metabolism such as an ammonium transporter, a xanthine/uracil/vitamin $\mathrm{C}$ permease, an acetamidase/formamidase, and two peptidases. These results are consistent with culture and field studies suggesting the importance of reduced and organic $\mathrm{N}$ in fueling $A$. anophagefferens blooms (reviewed in Gobler et al. 2005). When $\mathrm{P}$ is deficient, $A$. anophagefferens up-regulates a phosphate transporter, a 5'-nucleotidase, and an alkaline phosphatase. This suggests that $A$. anophagefferens may increase phosphate uptake capacity and utilize $\mathrm{P}$ from organic compounds such as nucleotides and esters. An additional experiment confirmed that $A$. anophagefferens could utilize adenosine monophosphate as its sole P source in culture.

A logical next step was to examine whether or not these changes in the transcriptome were manifested at the protein level. In the second data chapter (Chapter 3), shotgun mass spectrometry was used to detect proteins and monitor their abundance in nutrient replete, low $\mathrm{P}$, and P-refed conditions. Results demonstrated that $A$. 
anophagefferens increases the abundance of proteins involved in $\mathrm{P}$ scavenging, including a phosphate transporter, 5'-nucleotidase, and alkaline phosphatase. These results were consistent with results from Chapter 2 in which these same three genes were up-regulated at the transcriptional level. Additionally, the abundance of a sulfolipid biosynthesis protein increased during low $\mathrm{P}$ conditions. In the ocean, it has been demonstrated that some phytoplankton are able to reduce their $\mathrm{P}$ requirement by substituting $\mathrm{P}$ lipids with sulfolipids (Van Mooy et al. 2009). An analysis of lipids in A. anophagefferens revealed that under low P conditions, the sulfolipid sulphoquinovosyldiacylglycerol (SQDG) was nearly 1.5 -fold greater while cellular phospholipids were about 8 -fold less. Therefore, $A$. anophagefferens may be able to reduce its $\mathrm{P}$ quota or scavenge $\mathrm{P}$ from phospholipids under $\mathrm{P}$ deficiency. Comparison of protein abundances between the $-\mathrm{P}$ and $\mathrm{P}$-refed conditions identified variations in the timing of protein degradation and turnover. These results suggest that knowledge of protein turnover is critical in interpreting protein presence from metaproteomic datasets, which are often snapshot views of community protein levels.

In the final data chapter (Chapter 3), the goal was to develop a quantitative gene expression method for assaying $\mathrm{N}$ and $\mathrm{P}$ deficiency in natural populations of $A$. anophagefferens and apply this method to identify nutrient controls on natural blooms. Candidate genes were chosen based upon their expression patterns from Chapter 2 or from a previous study (Berg et al. 2008). A detailed time course culture experiment was performed to examine how expression patterns of these candidate genes changed as $A$. anophagefferens transitioned from a nutrient replete to $\mathrm{N}$ - or P-deficient conditions. Then, $\mathrm{N}$ or $\mathrm{P}$ was re-supplied to examine how quickly the $\mathrm{N}$ - and $\mathrm{P}$-deficient signals 
degraded. Results from this work illustrate that a xanthine/uracil/vitamin C permease (XUV) is significantly up-regulated as $A$. anophagefferens experiences $\mathrm{N}$ deficiency and the signal degrades within 2 hours after $\mathrm{N}$ re-supply. This gene is not regulated by $\mathrm{P}$ deficiency. Therefore, XUV is a good candidate for assaying $\mathrm{N}$ deficiency in natural populations. A phosphate transporter (PTA3) was significantly up-regulated under P deficiency and the signal degraded within 2 hours of P re-supply. This gene was not regulated by $\mathrm{N}$ deficiency. However, this gene was up-regulated when cells were actively growing on ammonium, although the fold-changes were far less than under $\mathrm{P}$ deficiency ( $\sim 40$-fold higher on ammonium, $\sim 500$-fold higher under $\mathrm{P}$ deficiency). Therefore, this gene is a good candidate for assaying P deficiency, and may also be a good candidate for tracking growth on ammonium. The expression patterns of XUV were tested on two samples from a 2007 A. anophagefferens bloom. Expression patterns showed that $A$. anophagefferens was not N-deficient during peak cell densities. Results from PTA3 expression show that $A$. anophagefferens may be utilizing ammonium as cell densities increase toward peak levels. This work represents a critical step in linking nutrient supply to $A$. anophagefferens bloom ecology.

\section{Implications}

A great deal of expression data was generated from this thesis. Although impossible to discuss every gene in detail, there were a few genes that were of particular interest that genes were discussed throughout the data chapters and are summarized in Table 1. An inorganic phosphate transporter is transcriptionally induced when $A$. anophagefferens experiences $\mathrm{P}$ deficiency. Subsequently, the protein for this gene 
becomes more abundant. Thus $A$. anophagefferens is either utilizing a higher affinity phosphate transporter, or increasing the number of phosphate transporters, to cope with low P. Upon P re-supply, the transcript for this gene is rapidly lost, while the protein remains abundant, suggesting that once this protein is made $A$. anophagefferens does not immediately degrade it when $\mathrm{P}$ is available. This could be due to the fact that it is a membrane protein and is not as accessible to degradation. Alternatively, $A$. anophagefferens may keep this protein available to deal with variable P supply.

A 5'-nucleotidase and alkaline phosphatase were both transcriptionally upregulated under $\mathrm{P}$ deficiency, with a concomitant increase in protein levels (Table 1). These enzymes scavenge $\mathrm{P}$ from organic sources. The 5'-nucleotidase cleaves phosphate from nucleotides and a signal peptide suggests that this enzyme is secreted. Therefore, exogenous nucleotides may be important for $A$. anophagefferens to meet its $\mathrm{P}$ demand. Alkaline phosphatases are also often associated with cell surfaces, again suggesting that exogenous esters may be a $\mathrm{P}$ source for $A$. anophagefferens. These results imply that exogenous organic $\mathrm{P}$ compounds may be fueling $A$. anophagefferens growth when inorganic forms are low or not available.

A variety of genes were transcriptionally regulated by $\mathrm{N}$ supply, many of which are involved with transport or metabolism of organic $\mathrm{N}$ compounds: nucleobases (purines/pyrmidines), amides, urea, formamide (Table 1). Another group is examining the protein responses as a function of $\mathrm{N}$ supply, so those data are unavailable at this time. However, insights from differential transcript abundance show that a xanthine/uracil/vitamin $\mathrm{C}$ permease, urea transporter, and acetamidase/formamidase are sensitive to $\mathrm{N}$ supply. As $A$. anophagefferens transitions into $\mathrm{N}$ deficiency, these genes 
are up-regulated, although the degree of regulation is variable among genes. As nitrate or ammonium is re-supplied to $\mathrm{N}$-deficient cells, these transcripts are repressed. These results imply that organic compounds, particularly urea, purines/pyrmidines, amides, and formamide are important sources of $\mathrm{N}$ when nitrate and ammonium are unavailable. It would require further investigation to determine if these expression patterns are also sensitive to nutrient type (e.g. growth on ammonium versus growth on urea). Nonetheless, these data support field studies that suggest an importance of organic compounds in fueling A. anophagefferens growth.

Due to the severe harm caused by $A$. anophagefferens, it is critical to devise potential mitigation and prevention strategies. From a pure $\mathrm{N}$ and $\mathrm{P}$ standpoint, it is clear that organic compounds serve as an important nutritional source for A. anophagefferens. This complicates the issue because the sources of these organic compounds are not well understood. For example, and increase in nitrate levels from groundwater could lead to increased biomass from other algae. This can, in turn, lead to an increase in organic compounds. Previous studies have shown that $A$. anophagefferens does not appear to be experiencing $\mathrm{N}$ deficiency over the course of a bloom, but the algal community as a whole could be (Gobler et al. 2005). Thus, trying to reduce $\mathrm{N}$ inputs into the system may inadvertently facilitate $A$. anophagefferens by hurting its competitors. More work needs to be done to understand whether $\mathrm{P}$ is ever limiting to A. anophagefferens, as this could be a more promising approach for mitigating or even preventing brown tides from occurring. 


\section{Future Directions}

Not surprisingly, this thesis raises additional questions and provides a platform for exciting future directions. First, advances in technology are facilitating deeper sequencing efforts. In Chapter 2, the transcriptional changes observed represent only the most highly expressed genes. Deeper sequencing during $\mathrm{N}$ and $\mathrm{P}$ deficiency would allow a higher resolution analysis of the global transcriptional responses. Additionally, transcriptome analysis over time would eliminate the problem of a snapshot view. For example, Chapter 3 illustrates how the proteome of $A$. anophagefferens changes in response to $\mathrm{P}$ deficiency and release from $\mathrm{P}$ deficiency, thus identifying differences in protein turnover/degradation. It would be valuable to determine how the transcriptome changes over time as A. anophagefferens transitions in and out of nutrient deficient conditions.

In Chapter 3, an unexpected result was the increased abundance of a sulfolipid biosynthesis protein under $\mathrm{P}$ deficiency. Oddly, this protein was even more abundant 24 hours after P-deficient cells were re-supplied with phosphate. Obtaining lipid data from a 24 hour re-feed would identify whether sulfolipids continued to increase and give a better idea of how quickly $A$. anophagefferens can adjust its cellular lipids to meet its $\mathrm{P}$ demands.

Gene expression assays for $\mathrm{N}$ and $\mathrm{P}$ deficiency were developed in Chapter 4. Due to time constraints, only a few samples from a natural bloom in 2007 were analyzed. Thanks to the efforts of Dr. Christopher Gobler's group at SUNY Stony Brook, samples have been collected throughout the bloom cycle over multiple years. Screening these samples for $\mathrm{N}$ and $\mathrm{P}$ deficiency and comparing between years would provide tremendous 
insight into the nutrient controls on brown tide blooms in Long Island. My future plans are to screen samples from a 2009 bloom in Quantuck Bay (Suffolk County, Long Island, $\mathrm{NY}$ ). Additionally, these gene targets are good indicators of $\mathrm{N}$ and $\mathrm{P}$ deficiency, but it may be possible to find other gene targets whose expression patterns are indicative of growth on a particular compound (e.g. urea). This would provide a new and useful approach for studying $A$. anophagefferens bloom ecology. 
Table 1. List of main genes discussed throughout multiple data chapters of this thesis, which chapters they are discussed in, and a summary of their behavior with respect to nitrogen $(\mathrm{N})$ and phosphorus $(\mathrm{P})$ supply.

\begin{tabular}{lll} 
& Gene & \\
Name & Symbol Chapters Function & Insights \\
\hline \hline
\end{tabular}

\begin{tabular}{|c|c|c|c|c|}
\hline $\begin{array}{l}\text { Inorganic phosphate } \\
\text { transporter }\end{array}$ & PTA3 & $2,3,4$ & Transports phosphate & $\begin{array}{l}\text { Under P deficiency, this gene is up-regulated at both the transcript } \\
\text { and protein level. The transcript is quickly lost upon P re-supply, } \\
\text { while the protein remains abundant for at least } 24 \text { hours. }\end{array}$ \\
\hline
\end{tabular}

5 '-nucleotidase $\quad$ NTD $2,3,4 \quad \begin{aligned} & \text { Cleaves phosphate from } \\ & \text { nucleotides }\end{aligned}$

Alkaline phosphatase

A

$\vec{\Xi}$

Xanthine/Uracil/Vitamin C permease

XUV $\quad 2,4$

Formate/Nitrite transporter

NAR $1.3 \quad 2,4$

Urea Transporter

DUR2 2,3,4 Transports urea

Acetamidase/ Formamidase FMD2 2,3,4 Hydrolyzes amides
Transports formate/nitrite

\author{
Transports nucleobases (purines \\ and pyrmidines) \\ Under $\mathrm{N}$ deficiency, this gene is up-regulated at the transcript \\ level. The transcript is rapidly lost upon re-supply of both nitrate \\ and ammonium.
}

Under $\mathrm{N}$ deficiency, this gene is up-regulated at the transcript level. The transcript is rapidly lost upon re-supply of both nitrate and ammonium.

Under $\mathrm{N}$ deficiency, this gene is up-regulated at the transcript level. The transcript is rapidly lost upon re-supply of both nitrate and ammonium. The protein for this gene is less abundant under $P$ deficiency.

Although this gene appears induced under $\mathrm{N}$ deficiency, the changes in expression are smaller compared to the other genes. The transcript is lost upon re-supply of both nitrate and ammonium, with ammonium causing the largest redusction, The protein for this gene is less abundant under P deficiency. 


\section{References:}

Berg, G.M., Shrager, J., Glockner, G., Arrigo, K.R., and Grossman, A.R. (2008) Understanding nitrogen limitation in Aureococcus anophagefferens (Pelagophyceae) through cDNA and qRT-PCR analysis. J. Phycol. 44: 1235-1249.

Dyhrman, S.T. (2008) Molecular approaches to diagnosing nutritional physiology in harmful algae: Implications for studying the effects of eutrophication. Harmful Algae 8: 167-174.

Gobler, C. J., Lonsdale, D.J., and Boyer, G.L. (2005) A review of the causes, effects, and potential management of harmful brown tide blooms caused by Aureococcus anophagefferens (Hargraves et Sieburth). Estuaries 28: 726-749.

Sunda, W.G., Graneli, E., and Gobler, C.J. (2006) Positive feedback and the development and persistence of ecosystem disruptive algal blooms. J. Phycol. 42: 963-974.

Van Mooy B.A.S., Fredricks H.F., Pedler B.E., Dyhrman S.T., Karl D.M. et al. (2009)

Phytoplankton in the ocean use non-phosphorus lipids in response to phosphorus scarcity. Nature 458: 69-72. 